\title{
Potential External (Non- DOE) Constraints on U.S. Fuel Cycle Options
}

Steven J. Piet

July 2012

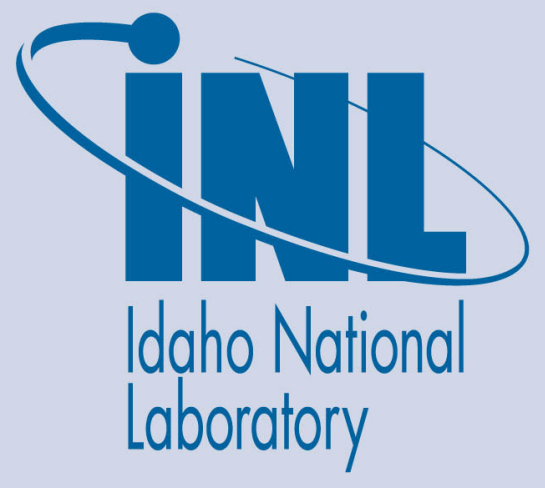

The INL is a U.S. Department of Energy National Laboratory operated by Battelle Energy Alliance 
INL/EXT-11-24289

FCRD-FCO-2012-000178

\section{Potential External (Non-DOE) Constraints on U.S. Fuel Cycle Options}

Steven J. Piet

July 2012

Idaho National Laboratory

Fuel Cycle Research \& Development

Idaho Falls, Idaho 83415

http://www.inl.gov

Prepared for the

U.S. Department of Energy

Office of Nuclear Energy

Under DOE Idaho Operations Office

Contract DE-AC07-05ID14517 


\section{DISCLAIMER}

This information was prepared as an account of work sponsored by an agency of the U.S. Government. Neither the U.S. Government nor any agency thereof, nor any of their employees, makes any warranty, expressed or implied, or assumes any legal liability or responsibility for the accuracy, completeness, or usefulness, of any information, apparatus, product, or process disclosed, or represents that its use would not infringe privately owned rights. References herein to any specific commercial product, process, or service by trade name, trade mark, manufacturer, or otherwise, does not necessarily constitute or imply its endorsement, recommendation, or favoring by the U.S. Government or any agency thereof. The views and opinions of authors expressed herein do not necessarily state or reflect those of the U.S. Government or any agency thereof. 


\section{SUMMARY}

The DOE Fuel Cycle Technologies (FCT) Program will be conducting a screening of fuel cycle options in FY2013 to help focus fuel cycle R\&D activities. As part of this screening, performance criteria and go/no-go criteria are being identified. To help ensure that these criteria are consistent with current policy, an effort was initiated to identify the status and basis of potentially relevant regulations, laws, and policies that have been established external to DOE. As such regulations, laws, and policies may be beyond DOE's control to change, they may constrain the screening criteria and internally-developed policy.

This report contains a historical survey and analysis of publically available ${ }^{a}$ domestic $^{b}$ documents that could pertain to external constraints on advanced nuclear fuel cycles. "External" is defined as public documents outside DOE. This effort did not include survey and analysis of constraints established internal to DOE. ${ }^{c}$

This document does not address what will be proposed for the FY2013 screening of fuel cycle options. It only reports on what has been found in surveying external public domestic documents. DOE documents were included mostly to provide context in the key 1974-1981 time period as fuel cycle, waste management, and proliferation policies were changing.

The author has found no U.S. public external document that imposes a legal or regulatory yes/no requirement on commercial nuclear fuel cycles with regard to any particular uranium enrichment, separation of plutonium or transuranic (TRU), purity of plutonium, separation of used fuel, breeder reactors, or recycling versus once-through/direct disposal.

In this summary and most of the main document, purple italics are used to differentiate statements of fact regarding contents of document versus the author's analysis thereof in any location for which confusion is a possibility.

The author's analysis of U.S. public external documents is that those documents suggest that each of these topics (as well as others) could impact the risk of regulatory disapproval, likelihood of continuing funding and policy support, and/or cost if built and operated.

\section{Organization of report}

Few topics being debated today have not been debated before. Therefore, the report has an historical orientation, including explanation of how various topics have evolved and a timeline of events relevant to U.S. fuel cycles.

The reader can delve into this report at four levels: 1) 10-page summary, 2) 30-page Chapter 2 containing analysis and integration of specific topics, 3) 149-pages of verbatim extracts from 115 documents in Chapter 4 , or 4 ) electronic archive of $\sim 280$ documents, which are listed in Chapter 3 . References are not hyperlinked, but the citation call-outs are in blue text for clarity.

a. Currently classified documents were not reviewed. It is possible that additional requirements, or explanation of public requirements, could exist in classified documents. Regarding the former, the author notes that when previously classified documents have been subsequently declassified (e.g., Carter1977, Bush1992) there were no additional requirements identified; indeed, maximization of policy impacts requires public disclosure and indeed there were public statements within a few days of the classified directives in 1977 and 1992 that contained the salient policy points.

b. A few IAEA documents were also assessed. IAEA documents have legal or regulatory force in the U.S. when adopted by U.S. entities, e.g., U.S. moves toward safeguards applied to U.S. non-military facilities. Also, IAEA criteria influence U.S. criteria, e.g., most of the criteria establishing safeguarding thresholds in INFCIRC/225 have been adopted in 10 CFR74.

c. While some DOE documents were analyzed as part of this effort, there was not a systematic assessment to identify internally generated policy. 
As this is a relatively unusual report, please note its organization, as follows:

- Summary

- Definition of acronyms and agencies: Includes brief explanation of CFR (Code of Federal Regulations), PL (Public Law), USC (United States Code), FR (Federal Register), General Accounting Office (GAO) (later renamed), Office of Technology Assessment (OTA), Congressional Research Service (CRS). GAO, OTA, and CRS all report (or reported) to Congress.

- Chapter 1: Introduction, including explanation of which types of documents were and were not reviewed in this report.

- Explanation of what regulations, laws, and policy statements are, and are not. The legal force and durability of a presidential policy statement, such as Carter's public statement in 1977[Carter1977] and his then-classified statement [PD/NSC-8] depends on whether there are laws granting or delegating authority.

- How are certain key words defined in law?

- Chapter 2: Analysis

- Analysis of specific topics: (1) Recycle versus once-through fuel cycles (using GAO's 1981 terminology as it outlined policy differences for Congress at a key point in time), (2) U235 criteria thresholds at $20 \%, 10 \%$, and 5\%, (3) Lack of U233 criteria, (4) Plutonium criteria thresholds, (5) TRU other than plutonium, (6) Pure plutonium and separated plutonium, (7) What is the "spent fuel standard" and does it have legal or regulatory force?, (8) When did the federal government begin offering to take used fuel from utilities?, (9) Why is spent fuel not defined as high-level waste (HLW)?, (10) Which candidate geologic repositories and "east of the Mississippi", and (11) When and why were fissile breeding ratio and transuranic conversion ratio defined?

- A timeline that addresses breeder reactors, reprocessing, plutonium separation, and uranium enrichment; these matters are interwoven and many events and documents are relevant to more than one of the topics.

- A table comparing relevant topics in the late 1970s-early 1980 s, 1990s, and now.

- Chapter 3: List of References

- Chapter 4: Text extracted verbatim from documents, sometimes with explanations or observations added (in purple italics to differentiate between the author's explanations and the original text).

- A database of source documents $(\sim 790 \mathrm{MB})$ available upon request and being placed in the DMS document database maintained by Kim Mousseau (INL).

\section{Findings on U235 enrichment criteria}

The author finds no laws or regulations prohibiting new U.S. commercial power plants from exceeding $20 \%$ U235/U-total.

10CFR50 defines HEU fuel as "fuel in which the weight percent of U-235 in the uranium is $20 \%$ or greater. Target material, special instrumentation, or experimental devices using HEU are not included." Nonpower reactors operate today with U-235 above $20 \%$ but new licenses will not be granted to new nonpower reactors with U235 over 20\%.[10CFR50.64] It is explicit policy established in law to keep 
U235 fuel enrichment below 20\% for nonpower reactors. [EnergyPolicyAct 1992] A U.S. High-Enriched Uranium (HEU)-fueled research reactor was cancelled in 1995 for this reason.[OTA-ISS-615] Nuclear Regulatory Commission (NRC) regulations mandate increased material controls [10CFR74] and additional physical security and safety (e.g. number of armed guards during transportation) [10CFR73] for any (commercial or nonpower) facility if $U 235$ is above $20 \%{ }^{d}$. The technical rationale for the $20 \%$ enrichment is documented elsewhere.[Forsberg 1998] The critical mass of uranium goes up as the enrichment goes down.

There is another step-function at $10 \%$ embedded in some (relatively minor) NRC regulations but neither policy nor law; in NRC regulations there are lower imposed restrictions below $10 \%$.

There is another step-function at 5\%: (a) applications for exports over 5\% U235 have to be reviewed by both the NRC and the Executive Branch[10CFR110.41] and (b) facility precedents, i.e., what enrichment, fuel fabrication, and reactor facilities have and have not asked to be licensed for.

A reviewer of a draft of this report, Charles Forsberg, noted that the $5 \%$ criticality criterion at $L W R$ fuel fabrication plants arose because it was thought that higher burnup (hence higher U235 enrichment) would not be possible because of fuel cladding material damage limits. Forsberg notes (and this author agrees) that many regulatory limits have no unchanging absolute basis except a value was adopted at the time, consistent with then-anticipated practice or application, that was known to be safe. In such situations, the value may not be at the edge of what could be found safe. This motivates taking an historical view as older numbers (or the lack of numbers) has to be viewed in historical context. The current lack of formal U233 criteria, in the next subsection, is an example. The current lack does not mean that new criteria would not arise if a Th/U233 fuel cycle were given serious consideration.

Forsberg goes on to state, "some of the new enrichment plants will have licenses for 6 or $7 \%$ U-235. Bottom line, in real centrifuge enrichment plant the cost of a somewhat higher enrichment capacity is very close to zero because most of the money is in the safety analysis where 5 or $6 \%$ enrichment is the number you plug into the computer code."

Based on current regulations, any fuel cycle over $20 \%$ U235/U-total would be required to have the highest degree of safeguards imposed by NRC or IAEA. Since no one appears to have proposed a commercial reactor or fuel cycle facility over $20 \%$, it cannot be known with certainty how various regulators and policy makers would respond. However, an analysis of the history of uranium enrichment policy suggests that any effort to have a new facility over $20 \%$ U235 would be highly controversial given that plans for new non-power reactors using over $20 \%$ U235 have been successfully blocked. See section 2.1.2 for more information on U235 enrichment criteria.

\section{Findings on U233 enrichment criteria}

The author finds no laws or regulations establishing criteria as a function of U233 enrichment. 10CFR74 and 10CFR75 do not make safeguards for material containing U233 to be a function of U233 enrichment; safeguards are only a function of the amount of U233 present. U233 inventories over $2 \mathrm{~kg}$ are designated "strategic special nuclear material," the most safeguarded category.

ORNL has published a technical report arguing for a U233 enrichment threshold of $12 \% \mathrm{U} 233 / \mathrm{U}$-total as analogous to the U235 20\% U235/U-total threshold,[Forsberg1998] but the author finds no evidence that that $12 \% \mathrm{U} 233$ threshold has been adopted into U.S. regulatory or policy documents.

d. Like 10CFR74, LAEA INFCIRC/225/Rev. 4 calls for more safeguard attention if the U235 enrichment is above $10 \%$ or above $20 \%$. 
Analysis: Any Th/U233 fuel cycle will involve over $2 \mathrm{~kg}-U 233$. Thus, any significant use of U233 might trigger full safeguards under current rules, independent of $U 233$ enrichment. Little regulatory attention has been paid to U233, which explains the relatively incomplete state of U233 criteria. Were a Th/U233 fuel cycle to be a serious contender for an actual facility in the U.S., it is likely that more criteria would be established. For example, a threshold on U233 could be established that is analogous to $20 \%$ U235/U-total. For now, the value of $12 \%$ U233/U-total has no regulatory basis in NRC or IAEA documents. See section 2.1.3 for more information on U233 enrichment criteria.

\section{Findings on plutonium enrichment criteria}

The IAEA exempts $\mathrm{Pu}$ with more than $80 \% \mathrm{Pu} 238 / \mathrm{Pu}$-total from being considered direct use material. [INFCIRC/225/Rev.4] This $80 \%$ Pu238 threshold ${ }^{e}$ does not appear in the analogous U.S. document 10CFR74, even though the material control and accounting requirements and thresholds are otherwise the same in the two documents. (The other difference regards the $100-\mathrm{rad} / \mathrm{hr}$ threshold separating "irradiated" and "unirradiated material", discussed later.) Thus, the current 10CFR74 invokes full safeguards on plutonium, regardless of the value of Pu238/Pu-total, if the mass of Pu exceeds $2 \mathrm{~kg}$.

The $80 \%$ threshold does appear in a few U.S. documents such as the Atomic Energy Act of 1954,[AEA1954] as amended, where it only factors into some of the allowances for foreign distribution of plutonium and 10CFR 110.42 where Pu over $80 \%$ Pu238 avoids some export restrictions and reviews.

Analysis: Thus, any significant use of Pu (over $2 \mathrm{~kg}$ ) might trigger full safeguards under current U.S. rules, independent of Pu isotopic enrichment. Were a fuel cycle with high Pu238/Pu-total to be a serious contender for an actual facility in the U.S., it is possible that the IAEA $80 \%$ threshold could be incorporated into U.S. rules. See section 2.1.4 for more information on plutonium enrichment criteria.

Note the parallel situation of U233 and Pu. Under current 1OCFR74, any amount of either material over $2 \mathrm{~kg}$ would trigger full NRC safeguard requirements; there are no isotopic clauses for $U 233 / U$-total or Pu238/Pu-total.

\section{Findings on minor actinide criteria}

There are few statements and regulations regarding any TRU other than plutonium, or regarding the inclusion (or not) of other TRU with plutonium. For example, the NRC staff recently noted that "americium (Am), neptunium (Np), and others are currently not regulated or treated as other fissile or SNM material."[SECY-09-0082] DOE Order 410.2 on management of nuclear materials does state that these are included as nuclear materials. TRU other than plutonium have not been focused on in the sort of policy-level documents relevant in this study. The only actinides at the policy-level are thorium, uranium, and plutonium.

Analysis - External domestic and IAEA documents have not addressed the minor actinides. DOE includes them as part of SNM but otherwise says nothing of relevance here. From the standpoint of current formal rules and regulations, the inclusion or not inclusion of minor actinides has no identifiable impact. There are proposals and analytical approaches that do recognize changes in material attractiveness for a weapon that are dependent on plutonium isotopic, uranium dilution of TRU, and the amount and composition of minor actinides. At present, these proposals have not been reflected in any rule or regulation of the NRC, IAEA, etc. See section 2.1.5 for more information on minor actinide criteria.

e. The $80 \%$ threshold is that plutonium with $80 \%$ or more Pu238 is categorized as less of a risk, presumably because of the heat generated by Pu238. 


\section{Findings on "no plutonium separation" and "no pure plutonium"}

The concepts of "no pure plutonium" and "no separation of plutonium" have not been found to be defined in public, external regulations nor laws. They do appear in technical analysis documents, but with varying definitions and interpretations.

10CFR73 states that MOX with over $20 \%$ plutonium would require NRC review on a case by case basis. NRC does not therefore automatically block MOX over $20 \% \mathrm{Pu}$.

Neither "no pure plutonium" nor "no separation of plutonium" have official external legal or regulatory definitions but they have appeared in technical analyses and non-government documents. There are multiple analysis definitions and interpretations

Because of the historical and current attention to phrases such as "no separated plutonium" or "pure plutonium" - or analogous SNM phrases - "no separated SNM" or "no pure SNM," it warrants explanation of what can be at stake. The formal definitions of strategic SNM, HEU, U233, and Pu in current regulations are clear and discussed in this report. HEU has an isotopic threshold, 20\% U235/U-total. In current U.S. regulations, U233 and Pu do not have isotopic thresholds; any amount over $2 \mathrm{~kg}$ appears to be SNM. Thus, U235 fuel cycles can avoid being labeled as SNM via isotopic threshold, but U233 and Pu cannot. Thus, the definition of the words "separated" or "pure" is the only flexibility of whether U233 and Pu fuel cycles would meet a "no separated SNM" or "no pure SNM" criterion if one were to be adopted.

Consider two cases found in the literature and the author's interpretation based on past documents and analyses. In both cases, to show the importance of how "separated" is interpreted, assume a policy is adopted - "no separated special nuclear material."

- Narrow interpretation: "no separated special nuclear material," applies to chemically pure Pu or U233.

- In this interpretation, most or all of the various recycle fuel cycles could be allowed as impurities and/or minor actinides are always mixed with Pu or U233.

- Broad interpretation: "no separated special nuclear material," applies to any fuel feedstock containing Pu or U233 (over the threshold inventory of $2 \mathrm{~kg}$ ).

- Under current U.S. rules, neither the $80 \%$ Pu238/Pu-total nor $12 \%$ U233/U-total thresholds would prevent fuels with Pu or U233 from being SNM. Therefore, in this interpretation, virtually all recycle options could be prohibited because they all involve some degree of separation of U233 or Pu239, albeit with other materials co-mingled.

Indeed, as the main document shows, the definition of "separated" has been argued for decades. See sections 2.1.6 for more information on "separation" and "pure plutonium".

\section{Findings on "spent fuel standard" and "self-protecting"}

The concepts of "spent fuel standard" and "self-protecting" have not been found to be defined in public, U.S. regulations nor laws. They do appear in technical analysis documents, but with varying definitions and interpretations.

Starting with Rev 1 of IAEA INFCIRC/225, in the context of physical protection of nuclear materials, the IAEA has defined the threshold between irradiated and unirradiated material as an exposure level of 100 $\mathrm{rad} /$ hour at 1 meter distance. This is commonly referred to the "self-protection" threshold. Their table on categorization of nuclear material defines unirradiated material as "Material not irradiated in a reactor or material irradiated in a reactor but with a radiation level equal to or less than $1 \mathrm{~Gy} / \mathrm{hr}(100 \mathrm{rad} / \mathrm{hr})$ at one 
meter unshielded." The analogous U.S. NRC categorizations appear in 10CFR74 and are identical except that the U.S. version is not in the form of a table and it lacks such a threshold.

Although the U.S. has no rule or regulation containing the above IAEA threshold, an unofficial selfprotection threshold of $100 \mathrm{rem} / \mathrm{hr}$ was developed during the (U.S.) National Academy of Science's plutonium disposition study. [NAS2000] Note that this study was not in the context of used commercial fuel, but rather disposition of excess plutonium, with fabrication into MOX followed by irradiation as one of the alternatives analyzed. Yet, one does find $100 \mathrm{rem} / \mathrm{hr}$ in the literature as a "self protecting" criterion for used commercial fuel.

Analysis - The new Bathke et al figures of merit regarding the attractiveness of nuclear material for weapon use [Bathke2009, Bathke 2010] are constructed as if a new threshold value was $500 \mathrm{rad} / \mathrm{hour}$, versus the old "self-protecting" value of $100 \mathrm{rem} / \mathrm{hour}$. The change from rem to rad is meant to be significant. The old U.S. formulation $(100 \mathrm{rem} / \mathrm{hr})$ was based on the idea of people avoiding cancer risk. The unit of "rem" (or Sv=100 rem) is meant to measure the risk of long-term or "chronic" health effects such as cancer or genetic damage. The new formulation in the figures of merit ( $500 \mathrm{rad} / \mathrm{hr}$ ) relates to personnel impairment. The unit of "rad" (or Gy=100 rad) measures the risk of short-term or "acute" health effects such as the LD50-60 (the dose causing 50\% of an exposed population to die within 60 days).

An incapacitation threshold of $500 \mathrm{rad} / \mathrm{hr}$ is based on the ORNL review of exposure data.[Coates2005] To date, the United States government has not issued an official radiation dose threshold above which the proliferation risk is so low as to be acceptable. (Statement confirmed by C. Bathke.)

See sections 2.1.7 for more information on "spent fuel standard" and "self-protecting".

\section{Findings on recycling and used fuel retrievability}

The topics of recycling and used fuel retrievability have been linked in policy over most of the time since 1944. As relevant policy has changed dramatically, to understand "recycling" and "retrievability", they need to be considered together and to be considered in three historical periods. The three periods are roughly 1944-1974, 1974-1981, and 1981-present.

There are two basic fuel cycle approaches that have been articulated, studied, and refined-recycling and direct disposal. When recycling was the assumed approach, used fuel retrievability was not required. After direct disposal became the assumed approach, used fuel retrievability became law.

\section{4 to $\sim 1974$ - a consensus on recycling, fast breeders, and no requirement for used fuel retrievability}

The first known detailed discussions about commercial nuclear power in this context occurred on April 26, 1944.[Koch2008] E. Fermi and others discussed the limited availability of uranium and stated that fast breeder reactors would be needed eventually, accompanied by recycling of used fuel.[text of the meeting minutes appears in Koch2008] Over time, this consensus view of breeding and recycling was increasingly explicit and formal, first by the AEC [AEC1962] and later at the presidential level recycling[Johnson1966] and the breeder.[Nixon1971] Until the Indian plutonium bomb test on May 18, 1974, all reports reviewed suggest a consensus - eventual transition to fast breeder reactors and disposal of the residual HLW after reprocessing. Indeed, spent fuel was deliberately not defined as HLW. [GAOEMD-77-41]

The National Academy of Sciences recommended salt as the environment for permanent geologic disposal in 1957.[NAS1957] Up through the mid-1970s, salt was the only medium studied in sufficient detail that specific geologic disposal candidate sites were identified, but eventually a few other media came to be considered. 
"Although the greatest effort in the early 1970s to locate a repository was focused on government owned land in southeastern New Mexico, regional investigations were also begun in the salt deposits of the Paradox, Appalachian, and Michigan basins, and on the Gulf Coast salt domes. Investigations of several rock types (argillite, granite, and volcanic tuff) at the Nevada Test Sites and of basalt at the Hanford Site were under way as were preliminary siting studies of bedded salt in the Pala Duro Basin of west Texas. Thus, by the mid-1970s, regions were under study that contains all of the sites that later became nominated as candidates for the first repository."[Lomenick1996]

Retrievability of the waste (assumed to be remnants after recovering actinides) was not an issue in this time period as it was assumed that used fuel would be recycled. However, intermediate half-life isotopes were an issue: "Separation of the $\mathrm{Cs}$ and $\mathrm{Sr}$ isotopes from the waste and their storage in small packages or surface tanks would of course greatly simplify the general problem of waste disposal."[NAS1957]

\section{$\sim 1974$ to $\sim 1981$ - a period of transition}

After the Indian test in 1974 to approximately 1981, many fuel cycle options were studied. In particular, reports from the domestic Nonproliferation Alternative Systems Assessment Program [NASAP1980] and International Nuclear Fuel Cycle Evaluation [INFCE1980] were published in 1980. A key paragraph from NASAP reads:

"All nuclear fuel cycles would entail some proliferation risks; there is no technical "fix".

Nevertheless, the light-water reactor fuel cycle with spent fuel discharged to interim storage does not involve weapons-usable material in any part of the fuel cycle and is a more proliferation-resistant nuclear power fuel cycle than other fuel cycles which involve highly enriched uranium or pure plutonium."

This paragraph is technical analysis, not policy, regulation, nor law. The second sentence puts HEU and "pure plutonium" in the same category: less proliferation-resistant than once-through. It does not, however, compare impure (e.g. mixed with minor actinides or fission products) or diluted plutonium (e.g. mixed with uranium) with once-through/direct disposal. (Analysis - The comparisons of impure or diluted plutonium versus once-through have been debated for over 30 years.) The proliferation volume of NASAP1980 indicates the concern with closed fuel cycles is that

"plutonium would appear in weapons-usable form and in forms that are relatively easy to exploit for weapons purposes. Without deployment constraints and suitable institutional arrangements, plutonium would appear in substantial and widespread inventories in bulk forms, which are inherently difficult to safeguard."[NASAP1980]

The range of opinions about proliferation (it is just institutional vs. it is so technical that we have to ban breeders and plutonium) was recognized by NASAP1980, which stated:

"The problem of proliferation, like all major national and international problems, is too complex to be solved by a single approach, technical or institutional. The NASAP report states that although the problem cannot be solved by technical means, it can be mitigated by technical means. It further states that technical and institutional approaches to the problem are related, though in diverse and complex ways from one fuel cycle to another, and that the combination of technical means and institutional arrangements can enhance the proliferation resistance of nuclear power systems."

The Barnwell PUREX separation plant for used PWR and BWR fuel was not canceled by Ford and Carter's change in policy in 1976-1977; [Ford 1976, Carter1977, PD/NSC-8] it was formally cancelled on October 15, 1981. Similarly, the Clinch River Breeder Reactor (CRBR) plant was not canceled by Ford and Carter's change in policy in 1976-1977; it was terminated on October 26, 1983 by the Senate voting 56-40 to terminate funding.[NWeek1983] (This vote had many motivations - reprocessing/proliferation, 
project cost, increased discoveries of uranium.) By 1983, the Nuclear Waste Policy Act of 1982 was in place. The NWPA incorporates items associated with both of the two fundamental fuel cycle approaches - recycling and once through, see summary table below.

After 1977 with the policy changed by Ford and Carter from recycling to direct disposal,[Ford1976, Carter 1977] the emphasis on retrievability arose. The Nuclear Waste Policy Act [NWPA] makes retrievability of directly disposed used fuel a requirement.

\section{1 to present - two fuel cycle approaches debated; both partially in NWPA}

Since 1981 there have been two fuel cycle approaches discussed and debated in the U.S. - once through/direct disposal (or "throw-away" as the GAO called it[EMD-81-78]) and reprocess (or "recycle option" as the GAO called it[EMD-81-78]). The table on the next page summarizes these two approaches, including how each have been partially integrated into the Nuclear Waste Policy Act, as amended. That is, to some degree, NWPA constrains both fuel cycle options.

The post-1981 version of the recycling approach observed in U.S. decision-making-level documents has had a major change from the pre-1974 version of the recycling approach-to mitigate proliferation concerns, after 1980 one does not observe decision-maker-level proposals for fast breeder reactors recycling with pure plutonium - there have been fast convertor/burner reactors (as opposed to breeders) and/or co-processing, spiking, etc. (as opposed to chemically pure plutonium). This connects back to the topics of "separation" and "pure plutonium".

The following summary table of the two basic fuel cycle approaches is the author's but the details and examples are each found in the documents cited.

Two Approaches Have Been Articulated for 30 Years

\begin{tabular}{|c|c|c|}
\hline $\begin{array}{l}\text { Names used by } \\
\text { GAO in } 1981 \text { or } \\
\text { NASAP in } 1980 .\end{array}$ & $\begin{array}{c}\text { "Throw-away", "Stow-away" [a], "Once- } \\
\text { through", "Direct disposal" }\end{array}$ & "Recycle", "Reprocessing" \\
\hline $\begin{array}{l}\text { Origin of } \\
\text { approach }\end{array}$ & $\begin{array}{l}\text { Consistent with, and catalyzed by, the } \\
1977 \text { policy change (no reprocessing, no } \\
\text { breeders) following the } 1974 \text { Indian } \\
\text { plutonium device. DOE first offered to } \\
\text { accept unprocessed used fuel in } 1977 .\end{array}$ & $\begin{array}{l}\text { Consistent with, and envisioned by, Fermi et al } \\
\text { in 1944.[see text of } 1944 \text { memo in Koch } 2008 \text { ] } \\
\text { Motivated by energy resources. Focus appears } \\
\text { solely on uranium and plutonium for roughly } 3 \\
\text { decades. }\end{array}$ \\
\hline What is disposed? & Spent fuel directly disposed.[Several docs] & $\begin{array}{l}\text { Plutonium and uranium recycled, not disposed. } \\
\text { Some options include minor actinide, Tc99, and } \\
\text { I-129 transmutation [GAO-RCED-94-16s] }\end{array}$ \\
\hline $\begin{array}{l}\text { Which geologic } \\
\text { environments have } \\
\text { been associated } \\
\text { with each } \\
\text { approach? }\end{array}$ & $\begin{array}{l}\text { The full range - basalt, salt dome, salt bed, } \\
\text { tuff, granite, clay, and borehole - have } \\
\text { been considered since mid-1970s. }\end{array}$ & $\begin{array}{l}\text { While recycle/reprocessing was the consensus } \\
\text { approach, salt dome and salt bed were the } \\
\text { predominant environments studied. }\end{array}$ \\
\hline $\begin{array}{l}\text { Which waste } \\
\text { parameters are } \\
\text { considered the } \\
\text { most important? }\end{array}$ & $\begin{array}{l}\text { A wide range of parameters have been } \\
\text { considered. DOE site cleanup program } \\
\text { has emphasized waste volume reduction } \\
\text { rather than heat and toxicity [GAO-03- } \\
593 \text {, OTA-O-171] }\end{array}$ & $\begin{array}{l}\text { Heat output is more important factor than } \\
\text { physical volume of the waste [OTA-O-171] } \\
\text { Waste from reprocessed spent fuel is simpler to } \\
\text { dispose of.[GAO-EMD-81-78] }\end{array}$ \\
\hline $\begin{array}{l}\text { How approach } \\
\text { appears in Nuclear } \\
\text { Waste Policy Act } \\
\text { of } 1982 \text {, as } \\
\text { amended }\end{array}$ & $\begin{array}{l}\text { Inhibits waste classification credit for } \\
\text { waste longevity reduction via } \\
\text { reprocessing.[NWPA } \sec 2 \text { and } \\
\text { SAND2010-6335] } \\
\text { Forbids use of waste fund for reprocessing } \\
\text { by not including it in what uses are }\end{array}$ & $\begin{array}{l}\text { Requires spent fuel retrievability before } \\
\text { repository closure with no explicit time } \\
\text { period,[NWPA sec 122] motivated by potential } \\
\text { for future fuel recycling.[GAO-EMD-81-78] } \\
\text { Differentiation of "spent fuel" and "high level } \\
\text { waste" [NWP sec 2] stems from the possible }\end{array}$ \\
\hline
\end{tabular}




\begin{tabular}{|l|l|l|}
\hline & allowed.[GAO-08-483] & recycle of "spent fuel".[GAO-EMD-77-41] \\
\hline $\begin{array}{l}\text { Key Presidential } \\
\text { policy statements } \\
\text { regarding } \\
\text { reprocessing }\end{array}$ & $\begin{array}{l}\text { "does not encourage the civil use of } \\
\text { plutonium and, accordingly, does not itself } \\
\text { engage in plutonium reprocessing for } \\
\text { either nuclear power or nuclear explosive } \\
\text { purposes."[Clinton1993] }\end{array}$ & $\begin{array}{l}\text { "decision not to produce plutonium and highly } \\
\text { enriched uranium for nuclear explosive } \\
\text { purposes."[Bush1992] }\end{array}$ \\
\hline a. Stow-away = stow for storage \\
\hline
\end{tabular}

\section{Types of Documents Surveyed and Analyzed}

This survey considered three types of documents.

1) Policy documents such as presidential statements or federal laws.

2) Policy assessment documents such as reports from the GAO, OTA, etc.

3) Technical (or mostly technical) documents. Some represent formal policy such as NRC regulations. Some suggest policy such as 1980 report of the Nonproliferation Alternative Systems Assessment Program. [NASAP1980]

Analysis: presidential policy statements can change project risk even if not enshrined in regulations or laws. How "policies" constrain decisions is itself a matter of policy.

The author was tasked to identify regulations, laws, and policies, external to DOE, that could constrain fuel cycle options. It is straightforward to identify the existence of regulations and laws. Regulations and laws constrain decisions unless changed. A federal law is, by definition, something approved by both Congress and the President at given point in time and therefore reflects policy as of that point in time. Regulations represent policy, by independent federal agencies (in the case of the NRC) or of the administration (in the case of most federal agencies).

When policies are embedded in regulations and laws, they are generally clear. However, in other cases, the concept and impact of "policy" can be nebulous. A policy not embedded in regulations and laws, even a policy held by the President, does not necessarily constrain fuel cycle options.

Presidents Carter and Clinton had clear policies to terminate the Clinch River Breeder Reactor (CRBR),[Carter1977, PD/NSC-8, Carter1977a, Carter1978, Carter1979, Clinton1993a, PDD-13] Barnwell separation plant for used PWR and BWR fuel, Experimental Breeder Reactor-II (EBR-II), and the Fast Flux Test Facility (FFTF). Their policies were not definitively translated into law or regulations. They were implemented not because of their presidential policies as legal documents, but because of the influence of them and their allies. ${ }^{\mathrm{f}}$

Analysis - The force of law exists only where and when a law explicitly grants authority to the president, cabinet department, or regulatory agency. With regard to fuel cycles, the only areas of direct public legal presidential authority found are export/import control decisions and information classification. In the fuel cycle arena, a presidential policy statement does not have the force of law as the long fights over Barnwell and Clinch River Breeder Reactor prove.

f. The record is clear that Carter and Clinton wished to terminate these four projects. Clinton was able to do so during his two terms of office. Carter was not able to do so during this single term of office, but the delays, doubts, and arguments of Carter and his allies proved successful in terminating CRBR and Barnwell after Carter left office. See chapter 2. 
It appears that the various laws (especially the Atomic Energy Act of 1954 as amended) have given the most legal authority in fuel cycle matters to the NRC, the next largest number of authorities to DOE, and the least directly to the president. It is common for a department or regulatory agency to have a legal authority that the president himself does not have.

Thus, how "policies" constrain decisions is itself a matter of "policy." For example, if a department has a legal authority, it is a matter of internal administration policy (not law) to what degree proposed department actions are first reviewed and approved by the White House. The NRC is called an "independent regulatory agency" because that degree of coordination is not expected. The author understands that cabinet secretaries serve at the pleasure of the president. (A new cabinet secretary does require Senate confirmation, absent a recess appointment.) In contrast, $N R C$ commissioners cannot be fired before their term of office expires. The exception is that the president has the authority to appoint an existing commissioner the new head commissioner, thus demoting the former head commissioner to only one of the five. If the president wants to appoint a new head commissioner not already on the commission, he has to obtain Senate approval.

Although a presidential policy statement relevant to a fuel cycle matter may not have the direct force of law, it can increase risk for a proposed course of action to appear to conflict with it. The Department of Energy (DOE) and executive branch appointees that serve at the direction of the president, and those legislators and NRC commissioners aligned with the president, can use their respective authorities to block a proposed project. Indeed, the executive branch could conceivably inhibit commercialization via importlexport decisions and make information flow more difficult via classification decisions.

An example of direct Presidential authority is the area of hardware and information control associated with classification, see GAO-RCED-87-150.

An example of independent federal agency authority that grants some degree of authority to the Executive Branch is the granting of export licenses for nuclear equipment.

"if the exporter knows, or has reason to believe, that the material will be used in any illegal activity or any activity related to isotope separation, chemical reprocessing, heavy water production or the fabrication of nuclear fuel containing plutonium, unless these activities are generically authorized under an appropriate agreement for cooperation." [10CFR110.20(d)]

This authority is not granted solely to the NRC. At 10CFR110.20(b), the NRC states that "Issuance of a general [export] license is coordinated with the Executive Branch." As an example of this authority being used, in 1992, "President G. H. W. Bush disapproved Long Island Power Authority's attempt to enter into a contract with the French firm Cogema to reprocess the slightly irradiated initial core from the decommissioned Shoreham reactor."[CRS2008] Long Island Power Authority was trying to recoup as much money as possible from the abandoned reactor.[Aron1997] This disapproval action was triggered by the Department of Defense [Aron1997] and may have been partially motivated by US-EURATOM disagreements regarding the U.S. asserted "right to consent to the reprocessing of fuel exported from the U.S.”[Carter1980, Bush1992, Clinton1993]

The above example also illustrates a limitation of this report. Despite considerable searching, the author was unable to find any deliberative document within the Executive Branch or by the NRC explaining the disapproval action. No such document was cited by the CRS or Aron 1997. 
Potential External Constraints

July 9,2012 


\section{CONTENTS}

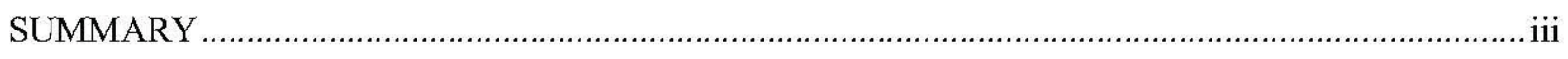

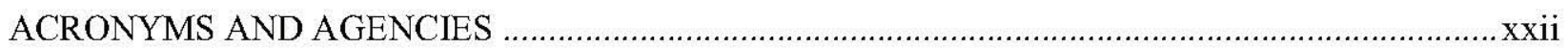

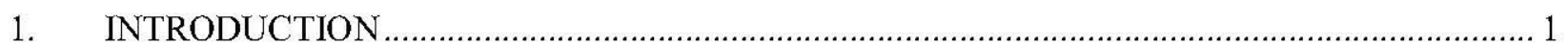

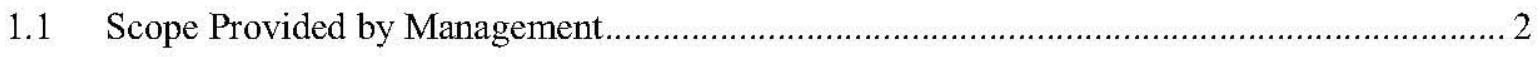

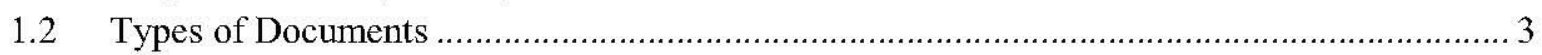

1.3 Laws, Regulations, Policy Statements, Guidance, Judicial Reviews, and Treaties .............. 6

1.4 How are some key words defined in laws and regulations? .......................................... 8

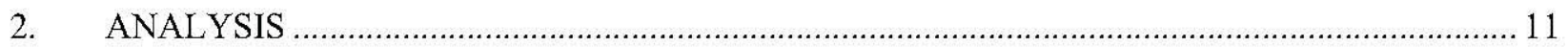

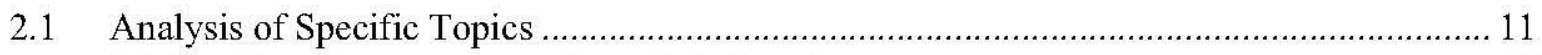

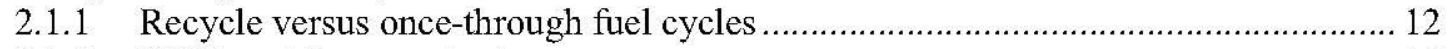

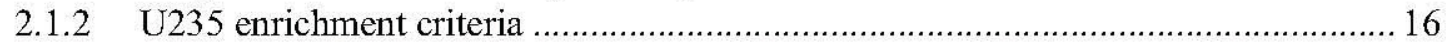

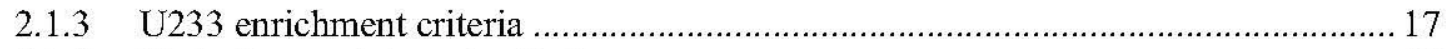

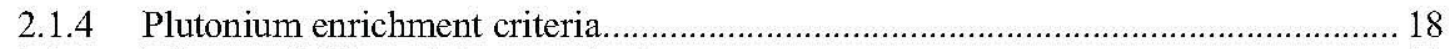

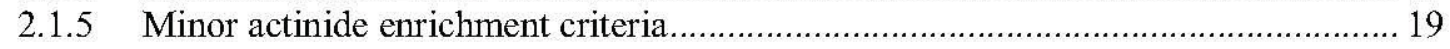

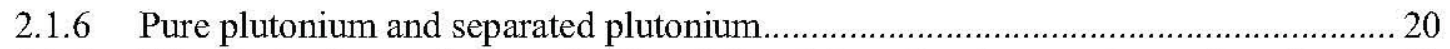

2.1.7 What is the "spent fuel standard" and does it have legal or regulatory force?......... 21

2.1.8 When did the federal government begin offering to take used fuel from utilities?

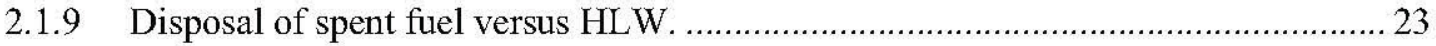

2.1.10 Candidate geologic repositories and "east of the Mississippi" ............................25

2.1.11 When and why were fissile breeding ratio and transuranic conversion ratio defined?

2.2 Integrated Timeline of Events and Documents .................................................. 30

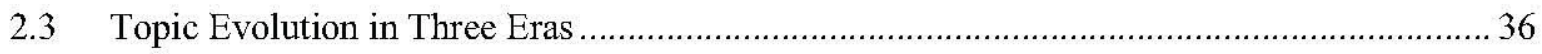

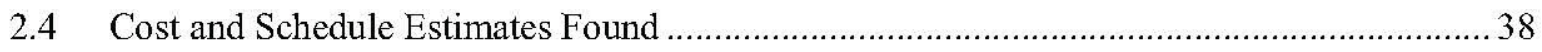

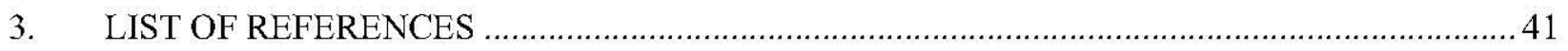

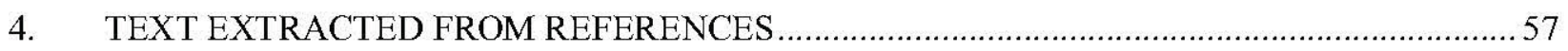

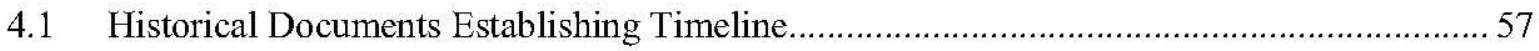

4.1.1 Restricted Data Declassification Decisions 1946 to the Present (RDD-8), January 1, 2002, http:/www.fas.org/sgp/othergov/doe/rdd-7.html. ...................5 57

4.1.2 Atomic Bombing of Hiroshima Announcement, Harry S. Truman, 1945 .............. 58

4.1.3 Henry DeWolf Symth, Atomic Energy for Military Purposes, "The Official Report on the Development of the Atomic Bomb under the Auspices of the United States Government," 1940-1945, August 12, $1945 .$.

4.1.4 United States Atomic Energy Commission, "Civilian Nuclear Power - a Report to the President - 1962," Washington DC, November 20, 1962, http://energyfromthorium.com/msrp/cnp1962/.....

4.1.5 Richard Nixon, "Special Message to the Congress on Energy Resources," June 4, 1971.

4.1.6 GAO, "The Liquid Metal Fast Breeder Reactor: Promises and Uncertainties," report GAO-OSP-76-1, July 1975. 
4.1.7 GAO, "Assessment of U.S. and International Controls over the Peaceful Uses of Nuclear Energy," report ID-76-60, September 14, 1976.

4.1.8 Memorandum of Conversation - President Ford; Louis deGuiringaud, Minister of Foreign Affairs of France; Dr. Henry A. Kissinger, Secretary of State Brent Scowcroft, Assistant to the President for National Security Affairs; Amb. Jacques Kosciusko-Morizet, Ambassador of France, October $1,1976$.

4.1.9 Gerald R. Ford, Radio Address on Peace / Statement on Nuclear Policy, Presidential Documents, vol. 12, no. 44, pp. 1626-1627, October 28, 1976.

4.1.10 Nuclear Energy Policy Study Group, Nuclear Power Issues and Choices, often called Ford/MITRE study, Ford Foundation, 1977.

4.1.11 J. E. Carter, "Nuclear Nonproliferation Policy," PD/NSC-8, March 24, 1977, Declassified on March 15, 1994.

4.1.12 Jimmy Carter Library, Records of the Speech Writer's Office, Statement on Nuclear Power Policy, April 7, 1977.

4.1.13 Jimmy Carter, "Nuclear Non-Proliferation - Message to Congress," April 27, 1977.

4.1.14 Jimmy Carter, "Nuclear Non-Proliferation Fact Sheet on the Proposed Nuclear Non-Proliferation Policy Act of 1977," April 27, 1977.

4.1.15 GAO, "Nuclear Energy's Dilemma: Disposing of Hazardous Radioactive Waste Safely," report EMD-77-41, September 9, 1977.

4.1.16 Jimmy Carter, "International Nuclear Fuel Cycle Evaluation Remarks at the First Plenary Session of the Organizing Conference," October 19, 1977.

4.1.17 GAO, "Review of the Present Status of the Clinch River Breeder Reactor Project," report EMD-78-49, March 6, 1978.

4.1.18 Jimmy Carter, "Nuclear Non-Proliferation Act of 1978 Statement on signing H.R. 8638 into Law," March 10, 1978.

4.1.19 GAO, "An Evaluation of Federal Support of the Barnwell Reprocessing Plant and the Department of Energy's Spent Fuel Storage Policy," report EMD-78-97, July 20, 1978.

4.1.20 Jimmy Carter, "Clinch River Breeder Reactor Statement on Action by the House Science and Technology Committee," April 27, 1979.

4.1.21 GAO, "The Clinch River Breeder Reactor - Should Congress Continue to Fund it?," report EMD-79-62, May 7, 1979.

4.1.22 GAO, "Nuclear Reactor Options to Reduce the Risk of Proliferation and to Succeed Current Light Water Reactor Technology," report EMD-79-15, May 23, 1979.

4.1.23 GAO, "Federal Facilities for Storing Spent Nuclear Fuel - Are They

Needed," report EMD-79-82, June 27, 1979.

4.1.24 Final Report of the Committee on Nuclear and Alternative Energy Systems (CONAES), Energy in Transition, 1985-2010, December 25, 1979. This was delivered to the Secretary of Energy on this date, copyrighted in 1980, and published in 1982 .

4.1.25 International Nuclear Fuel Cycle Evaluation, INFCE/CP/2/9, January 1980. (Summary and 8 working group reports).....

4.1.26 GAO, "Nuclear Fuel Reprocessing and the Problems of Safeguarding Against the Spread of Nuclear Weapons," report EMD-80-38, March 18, 1980 .

4.1.27 NASAP (Nonproliferation Alternative Systems Assessment Program). 1980.

"Nuclear Proliferation and Civilian Nuclear Power, Report of the 
Nonproliferation Alternative Systems Assessment Program," report

DOE/NE-001, Executive Summary, volumes I to IX, June 1980.

4.1.28 GAO, "U.S. Breeder Reactor Program Needs Direction," report EMD-80-

81 , September 22, 1980 .

4.1.29 DOE, "Final Environmental Impact Statement - Management of

Commercially Generated Radioactive Wastes," DOE/EIS-0046F, October

1980 .

4.1.30 GAO, "Is Spent Fuel or Waste From Reprocessed Spent Fuel Simpler to

Dispose Of?," report EMD-81-78, June 12, 1981

4.1.31 R. W. Reagan, "Statement Announcing a Series of Policy Initiatives on

Nuclear Energy," October 8, 1981.

4.1.32 GAO, "DOE Confident It Can Fuel the Clinch River Breeder Reactor and other Breeder Reactor Projects," report EMD-82-89, May 14, 1982. 102

4.1.33 Nucleonics Week, October 27, 1983, Special issue on the defeat of the CRBR in the Senate on October 26 ...

4.1.34 DOE, "DRAFT Area Recommendation Report for the Crystalline Repository Project - Overview," report DOE/CH-15(0), January 1986

4.1.35 David J. Rose, Learning about Energy, Plenum Press, New York, 1986. 104

4.1.36 DOE, "Briefing on the Draft Area Recommendation Report, Crystalline Repository Project," January-February, 1986.

4.1.37 DOE, "A Multiattribute Utility Analysis of Sites Nominated for Characterization for the First Radioactive-Waste Repository - A DecisionAiding Methodology," DOE/RW-0074, May 1986.

4.1.38 GAO, "Nuclear Waste - Issues Concerning DOE's Postponement of Second Repository Siting Activities," report RCED-86-200FS, July 30, 1986.

4.1.39 GAO, "Nuclear Nonproliferation - Department of Energy Needs Tighter Controls over Reprocessing Information," report RCED-87-150, August 1987.

4.1.40 Allied-General Nuclear Services, et al., Petitioners v. United States of America; brief for the United States in Opposition, 1988.

4.1.41 DOE, "Analysis of the Total System Life Cycle Cost for the Civilian Radioactive Waste Management Program," report DOE/RW-0236, May 1989.

4.1.42 DOE, "Preliminary Estimates of the Total-System Cost for the Restructured Program: An Addendum to the May 1989 Analysis of the Total-system Life Cycle Cost for the Civilian Radioactive Waste Management Program," report DOE/RW-0295SP, December 1990.

4.1.43 G. H. W. Bush, "President's Statement," Office of the Press Secretary, July $13,1992$.

4.1.44 White House, Office of the Press Secretary, "Non-proliferation Initiative," Fact sheet, July 13, 1992.

4.1.45 W. J. Clinton, "Non-Proliferation and Export Control Policy," Presidential Decision Directive-13 (PDD-13), September 1993.

4.1.46 "Fact Sheet - Nonproliferation and Export Control Policy," The White House, Office of the Press Secretary, September 27, 1993.

4.1.47 OTA, "Dismantling the Bomb and Managing the Nuclear Materials," report OTA-O-572, September 1993.

4.1.48 GAO, "Nuclear Science - Developing Technology to Reduce Radioactive Waste May Take Decades and Be Costly," report RCED-94-16s, December 1993. 
4.1.49 NAS1994, Committee on International Security and Arms Control, "Management and Disposition of Excess Weapons Plutonium," National Academy Press, Washington DC, 1994.

4.1.50 OTA, "Technical Options for the Advanced Liquid Metal Reactor," report OTA-BP-ENV-126, May 1994.

4.1.51 NAS1995, Committee on International Security and Arms Control, Panel on Reactor-Related Options, "Management and Disposition of Excess Plutonium: Reactor-Related Options." National Academy Press, Washington, D.C., 1995.

4.1.52 OTA, "Nuclear Safeguards and the International Atomic Energy Agency," report OTA-ISS-615, April 1995.

4.1.53 W. H. Hannum, D. C. Wade, H. F. Macfarlane, and R. N. Hill, "Nonproliferation and Safeguards Aspects of the IFR," Progress in Nuclear Energy, 31 (1-2), pp. 203-217, 1997.

4.1.54 C. W. Forsberg, C. M. Hopper, J. L. Richter, H. C. Vantine, Definition of Weapons-Usable Uranium-233, ORNL/TM-13517, March 1998.

4.1.55 DOE, "Analysis of the Total System Life Cycle Cost of the Civilian Radioactive Waste Management Program," report DOE/RW-0510, December 1998.

4.1.56 Rob P. Rechard, "Historical Background on the Performance Assessment for the Waste Isolation Pilot Project," report SAND99-2719J, March 1999.

4.1.57 Report by the TOPS Task Force of the Nuclear Energy Research Advisory Committee (NERAC), "Annex: Attributes of Proliferation Resistance for Civilian Nuclear Power systems," October 2000.

4.1.58 Report by the TOPS Task Force of the Nuclear Energy Research Advisory Committee (NERAC), "Technological Opportunities to Increase the Proliferation Resistance of Global Civilian Nuclear Power Systems (TOPS)," January 2001.

4.1.59 DOE, "Analysis of the Total System Life Cycle Cost of the Civilian Radioactive Waste Management Program," report DOE/RW-0533, May 2001.

4.1.60 National Energy Policy Development Group, "National Energy Policy," May 2001.

4.1.61 George W. Bush, "Letter to Congressional Leaders Recommending the Yucca Mountain Site for the Disposal of Spent Nuclear Fuel and Nuclear Waste," February 15, 2002.

4.1.62 P. Weiss, "Little-studied metal goes critical - Neptunium Nukes?," Science News. October 26, 2002

4.1.63 "National Strategy to Combat Weapons of Mass Destruction," December 2002.

4.1.64 GAO, "Nuclear Waste - Challenges to Achieving Potential Savings in DOE's High-Level Waste Cleanup Program," report GAO-03-593, June 2003.

4.1.65 Catherine Westfall, "Vision and reality: The EBR-II story," Nuclear News, February 2004, pp. 25-32.

4.1.66 Matthew Bunn, "Proliferation-Resistance (and Terror-Resistance) of Nuclear Energy Systems," Managing the Atom Project, Harvard University, Lecture for "Nuclear Energy Economics and Policy Analysis", April 12, 2004, http://www.ksg.harvard.edu/bcsia/atom.

4.1.67 Thomas Graham, Jr., Common Sense on Weapons of Mass Destruction, 2004 . 
4.1.68 GAO, "Securing U.S. Nuclear Materials - DOE Needs to Take Action to Safely Consolidate Plutonium," report GAO-05-665, July 2005

4.1.69 George W. Bush, February 20, 2006, page 297 of 2006 presidential papers......... 147

4.1.70 "The National Security Strategy of the United States of America", March $2006 .$.

4.1.71 George W. Bush, May 24, 2006, page 1007 of 2006 presidential papers.............. 148

4.1.72 GAO, "Nuclear Waste - Plans for Addressing Most Buried Transuranic Wastes Are Not Final, and Preliminary Cost Estimates Will Likely Increase," report GAO-07-761, June 2007.

4.1.73 Anthony Andrews, "Nuclear Fuel Reprocessing: U.S. Policy Development," Congressional Research Service, RS22542, November 29, 2006; updated March 27, 2008.

4.1.74 GAO, "Global Nuclear Energy Partnership - DOE Should Reassess Its Approach to Designing and Building Spent Nuclear Fuel Recycling Facilities," report GAO-08-483, April 2008.

4.1.75 DOE, "Analysis of the Total System Life Cycle Cost of the Civilian Radioactive Waste Management Program, Fiscal Year 2007," report DOE/RW-0591, July 2008.

4.1.76 Ken-ichi Yoshioka, Shouichi Watanabe, Ishi Mitsuhashi, Satoshi Gunji, Mitsuaki Yamaoka, Kouji Hiraiwa, A Minimal-Content Gadolinia in Above-5wt\% Enrichment Fuel for Criticality Safety in Next-Generation LWR, Advances in Nuclear Fuel Management IV (ANFM 2009), Hilton Head Island, South Carolina, USA, April 12-15, 2009.

4.1.77 Dale Lancaster, Charles Rombough, Francis Alcorn, Thomas P. McLaughlin, "Critical Safety Issues Associated with Uranium Enriched Up to Ten Weight Percent," Advances in Nuclear Fuel Management IV (ANFM 2009), Hilton Head Island, South Carolina, USA, April 12-15, 2009.

4.1.78 Michael F. Weber, Director, Office of Nuclear Material Safety and Safeguards, Nuclear Regulatory Commission, "Update on Reprocessing Regulatory Framework-Summary of Gap Analysis," SECY-09-0082, May 28,2009

4.1.79 Matthew Bunn and Martin B. Malin, "Enabling a Nuclear Revival—And Managing Its Risks," Innovations, Fall 2009, pp. 173-191

4.1.80 "National Security Strategy," May 2010. 156

4.1.81 Rob P. Rechard, Tom Cotton, Hank C. Jenkins-Smith, Mark Nutt, Joe Carter, Frank Perry, Ruth F. Weiner, James A. Blink, "End of FY10 Report

- Used Fuel Disposition Technical Bases and Lessons Learned - Legal and Regulatory Framework for High-Level Waste Disposition in the United States," SAND2010-6335, September 2010.

4.1.82 World Nuclear Organization, Research Reactors, Updated March 2011, http://world-nuclear.org/info/inf61.html

4.1.83 Mark Holt/CRS, "Civilian Nuclear Waste Disposal," Congressional Research Service report RL33461, August 30, 2011.................................. 160

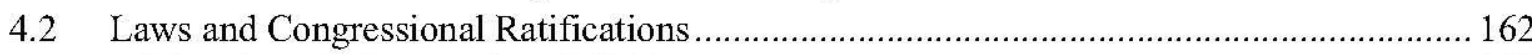

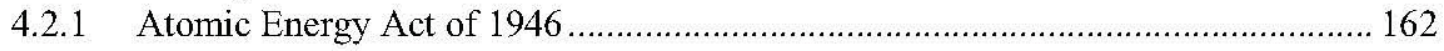

4.2.2 Atomic Energy Act of 1954, as amended (P.L. 83-703) ............................... 162

4.2.3 International Atomic Energy Agency Participation Act of 1957 (P.L. 85177)

4.2.4 Energy Reorganization Act of 1974, as amended (P.L. 93-438) ....................... 165

4.2.5 Department of Energy Organization Act of 1977 (P.L. 95-91) 
4.2.6 The Nuclear Non-Proliferation Act of 1978 (P.L. 95-242)

4.2.7 U.S. Senate Resolution Consenting to the Ratification of the Agreement Between the U.S. and the IAEA for the Application of Safeguards (July 2, 1980.)

4.2.8 Convention on the Physical Protection of Nuclear Material Implementation

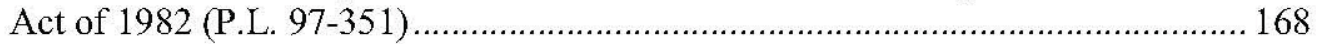

4.2.9 Nuclear Waste Policy Act of 1982, as amended (97-425) ............................... 168

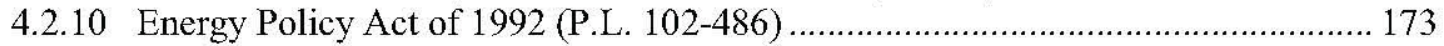

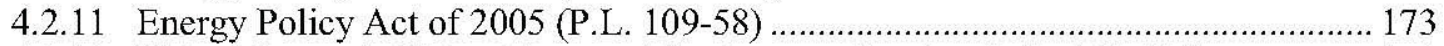

4.2.12 United States Additional Protocol Implementation Act (P.L. 109-401) ................ 173

4.3 Title 10, Code of Federal Regulations, Chapter I, Nuclear Regulatory Commission......... 176

4.3.1 Fact Sheet on Uranium Enrichment, May 2009, http://www.nrc.gov/reading$\mathrm{rm} /$ doc-collections/fact-sheets/enrichment.html ............................................. 177

4.3.2 Part 50 - Domestic Licensing of Production and Utilization Facilities .................. 177

4.3.3 Part 52 - Licenses, Certifications, and Approvals for Nuclear Power Plants......... 180

4.3.4 Part 60-Disposal of High-Level Radioactive Wastes in Geologic

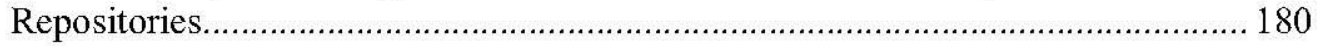

4.3.5 Part 61 - Licensing Requirements for Land Disposal of Radioactive Waste......... 181

4.3.6 Part 62 - Criteria and Procedures for Emergency Access to Non-Federal and Regional Low-Level Waste Disposal Facilities............................................. 184

4.3.7 Part 63 - Disposal of High-Level Radioactive Wastes in a Geologic Repository at Yucca Mountain, Nevada. ................................................... 184

4.3.8 Part 70 - Domestic Licensing of Special Nuclear Material................................... 184

4.3.9 Part 71 - Packaging and Transportation of Radioactive Material. ....................... 187

4.3.10 Part 72 - Licensing Requirements for the Independent Storage of Spent Nuclear Fuel, High Level Radioactive Waste, and Reactor-Related Greater than Class C Waste.

4.3.11 Part 73 - Physical Protection of Plants and Materials. .................................... 188

4.3.12 Part 74 - Material Control and Accounting of Special Nuclear Material.............. 190

4.3.13 Part 75 - Safeguards on Nuclear Material - Implementation of US/IAEA

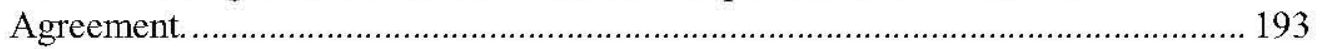

4.3.14 Part 76 - Certification of Gaseous Diffusion Plants........................................ 194

4.3.15 Part 110 - Export and Import of Nuclear Equipment and Material....................... 195

4.3.16 Part 140 - Financial Protection Requirements and Indemnity Agreements. ..........201

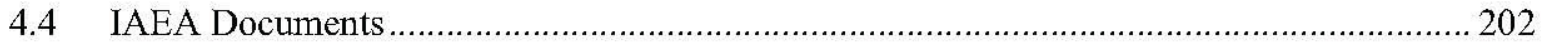

4.4.1 IAEA, "Treaty on the Non-Proliferation of Nuclear Weapons,"

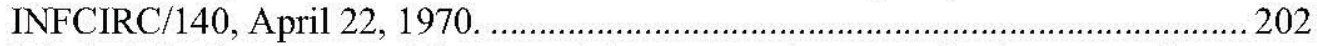

4.4.2 IAEA, "The Structure and Content of Agreements Between the Agency and States Required in Connection with the Treaty on the Non-Proliferation of Nuclear Weapons," INFCIRC/153, June 1972 ............................................. 202

4.4.3 IAEA, "The Physical Protection of Nuclear Material," INFCIRC/225,

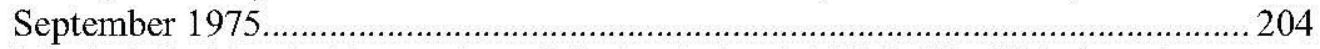

4.4.4 IAEA, "The Physical Protection of Nuclear Material," INFCIRC/225/Rev.4 (Corrected), June 1999.

\section{FIGURES}

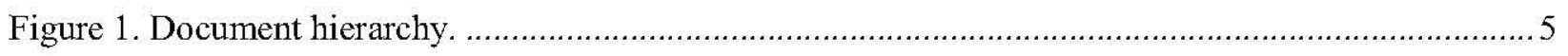

Figure 2. Cost data encountered during the course of this study (billions of then-current dollars)...........39 
Figure 3. Crystalline Rock Regions Being Considered for Second Repository................................ 106

Figure 4. Proposed Potentially Acceptable Sites and Candidate Areas for the Second Repository. 107

\section{TABLES}

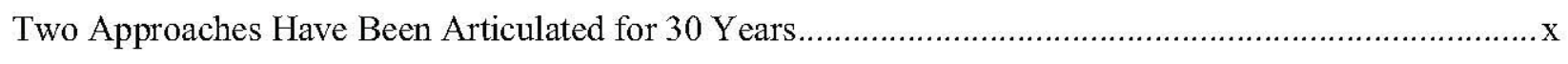

Table 1 of report. Two Approaches Have Been Articulated for 30 Years......................................... 15

Table 2 of report. Evolution of Geologic Repository Candidate Geologic Environments. ...................22

Table 3 of report. Timeline of Events and Documents Assembled for this Report. ............................ 30

Table 4 of report. Comparison of Topics in Three Eras. ............................................................... 37

Table 5 of report. Cost Data Assembled During the Course of this Study (Billions of Then-

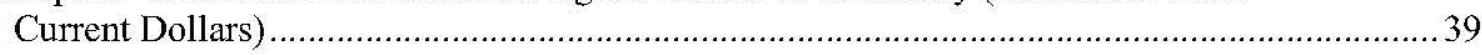

Table 6 of report. Table 3.3-2. Characteristics of Activities Required for Plutonium Production from Different Separation and Reprocessing Schemes. ................................................. 96

Table 7 of report. Author's Summary Table of Report RCED-94-16s.......................................... 119

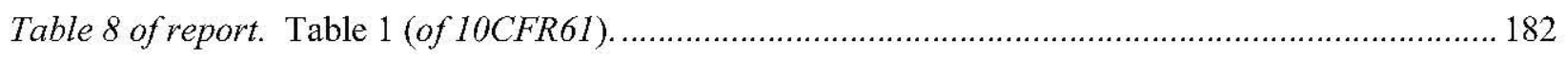

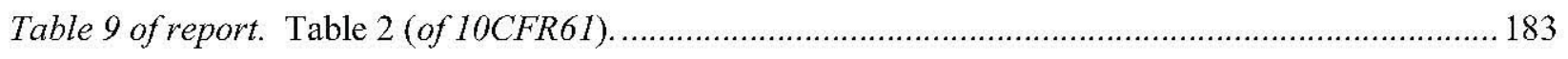

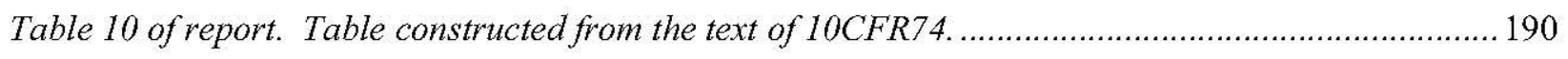

Table 11 of report. Table 1 (of 10CFR110 Appendix P) - Import and Export Threshold Limits...........200

Table 12 of report. Table I (of INFCIRC/225). Categorization of Nuclear Material............................204

Table 13 of report. Table (of INFCIRC/225/Rev4): Categorization of Nuclear Material.....................205 
Potential External Constraints

July 9,2012 


\section{ACRONYMS AND AGENCIES}

The following figure shows a timeline of key agencies and laws. White boxes denote independent agencies. Purple boxes are Executive Branch agencies. Olive boxes denotes laws; once passed, relevant laws have remained in effect (often with subsequent amendments) with the exception of the Atomic Energy Act of 1946,[AEA1946] which was replaced by the Atomic Energy Act of 1954.[AEA1954] Orange denotes agencies of Congress.

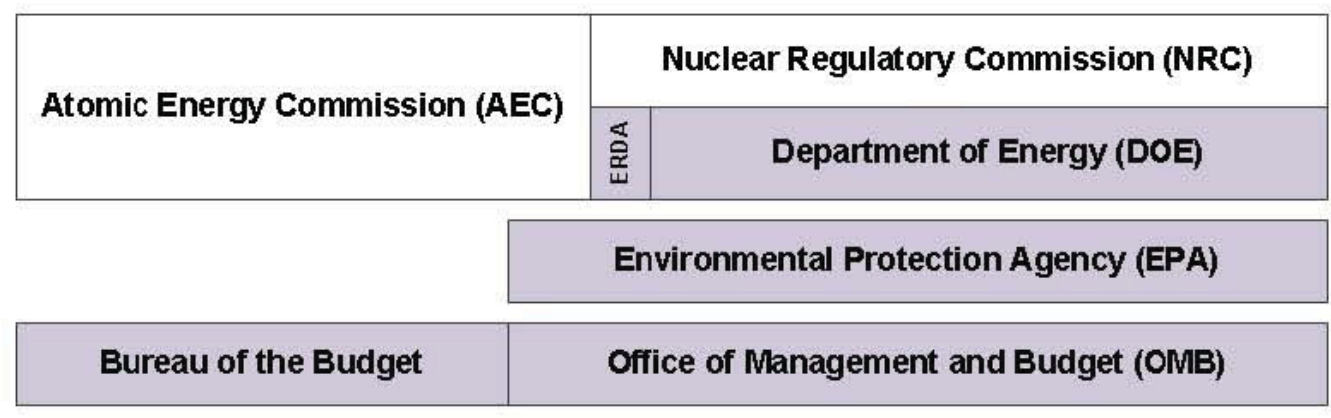

\begin{tabular}{l|r|}
\hline A.E.A of 1946 & Atomic Energy Act of 1954 \\
\hline & IAEA Participation Act of 1957 \\
\hline National Environmental Policy Act (NEPA) \\
\hline Nuclear Non-Proliferation Act of 1978 \\
Nuclear Waste Policy Act of 1982 \\
\hline
\end{tabular}
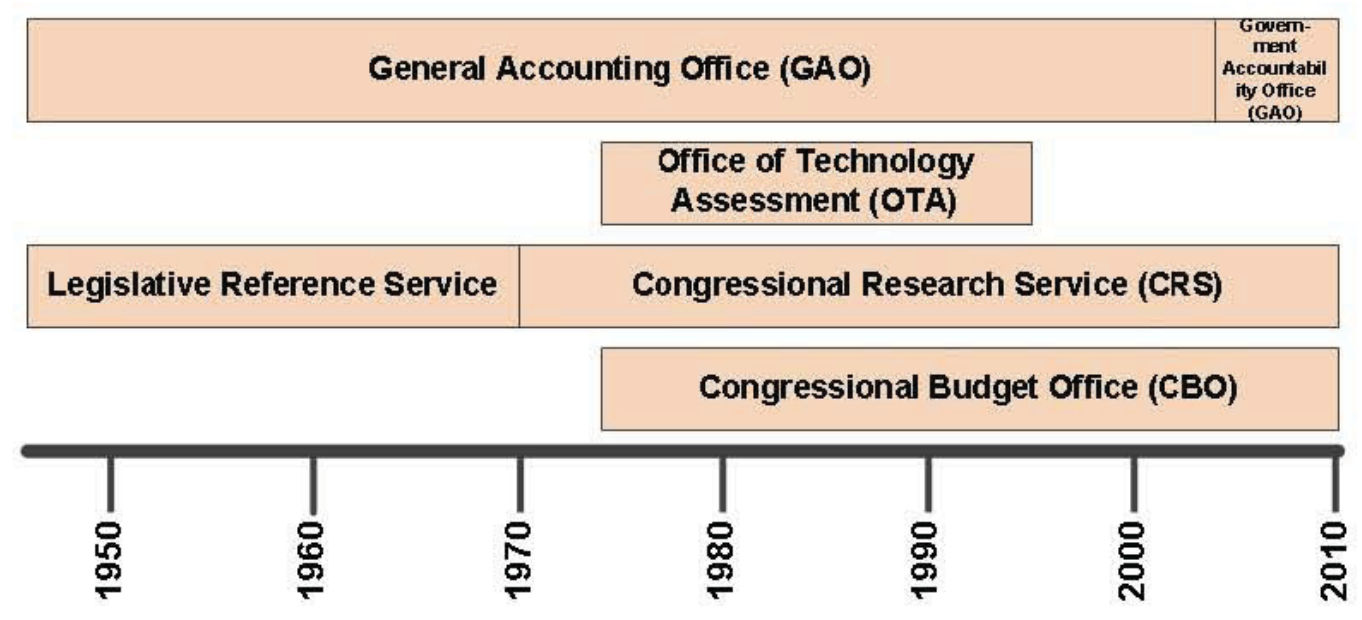

a.k.a. also known as

AEC Atomic Energy Commission, established by the Atomic Energy Act of 1946,[AEA1946] modified by the Atomic Energy Act of 1954,[AEA1954] abolished by the Energy Reorganization Act of 1974.

ANL Argonne National Laboratory

ANS American Nuclear Society 
CBO Congressional Budget Office, created by the Congressional Budget and Impoundment Control Act (P.L. 93-344) signed by President Nixon on July 12, 1974.

CFR Code of Federal Regulations. Each "Chapter" of each "Title" indicates which agency or department has authority over that set of regulations. Chapters are divided into "Parts". A U.S. regulation is commonly referred as $\mathbf{x x C F R y y}$ where $\mathrm{xx}$ is the Title and yy is the Part. The "Chapter" does not have to be specified as it can be inferred by the value of yy as follows:

Title 10 is "Energy".

- Parts 1-199 comprise Chapter I, Nuclear Regulatory Commission.

- Parts 200-999 comprise Chapters II, III, and X, Department of Energy, e.g., Part 961 is "Standard Contract for Disposal of Spent Nuclear Fuel and/or High-Level Radioactive Waste."

- Parts 1303-1304 comprise Chapter XIII, Nuclear Waste Technical Review Board

- Parts 1703-1707 comprise Chapter XVII, Defense Nuclear Facilities Safety Board

- Parts 1800 is Chapter XVIII, Northeast Interstate Low-Level Radioactive Waste Commission

Title 40 is "Protection of the Environment"

- Parts 1 to 1068 comprise Chapter I, Environmental Protection Agency

- Part 1400 is Chapter IV, Environmental Protection Agency and Department of Justice

- Parts 1510-1518 comprise Chapter V, Council on Environmental Quality

- Parts 1600-1620 comprise Chapter VI, Chemical Safety and Hazard Investigation Board Part 1700 is Chapter VII, Environmental Protection Agency and Department of Defense; Uniform National Discharge Standards for Vessels of the Armed Forces

CP-1 Chicago Pile-1, the first fission reactor

C.R. Congressional Record, is "the official record of the proceedings and debates of the United States Congress. It is published daily when Congress is in session." www.gpoaccess.gov/crecord/index.html

CRBR Clinch River Breeder Reactor, proposed for eastern Tennessee.

CRS Congressional Research Service, the public policy research arm of the congress, its current name dates from the Legislative Reorganization Act of 1970, but its predecessors (such as the Legislative Reference Service) date back to approximately 1914.

DOE U.S. Department of Energy, established by the Department of Energy Organization Act of 1977. Its regulations are found in 10CFR Parts 200 to 999.

EBR Experimental Breeder Reactor, I and II, Idaho Falls, Idaho.

\section{EO Executive Order}

EPA Environmental Protection Agency, established in 1970 by executive order by President Richard Nixon (Reorganization Plan No. 3) as a single agency formed from several smaller agencies. This was in turn ratified by both houses of Congress and yet later codified into law. Its regulations are found in 40CFR Parts 1 to 1068 . 
ERDA Energy Research and Development Administration, established by the Energy Reorganization Act of 1974, subsumed by the Department of Energy by the Department of Energy Organization Act of 1977.

FR Federal Register is the "official daily publication for rules, proposed rules, and notices of Federal agencies and organizations, as well as executive orders and other presidential documents." A FR citation is often written as $\mathbf{x x ~ F R ~ y y , ~ w h e r e ~} \mathrm{xx}$ is the volume and yy is the page number. www.gpoaccess.gov/fr/

FR Full Recycle (not used in this report)

FR Fast Reactor (not used in this report)

FFTF Fast Flux Test Facility, Richland Washington.

FY Fiscal year

GAO Government Accountability Office (called General Accounting Office before 2004), investigative arm of Congress established by the Budget and Accounting Act of 1921.

GEIS Generic Environmental Impact Statement

GTCC Low-level radioactive waste that is "greater than class $\underline{C}$ ", hence generally not suitable for near-surface burial. Waste is GTCC if it contains specific long-lived isotopes at concentrations greater than that in Table 1 of 10CFR61 or excessive external radiation and/or heat generation per Table 2 of 10CFR61.

HEU High enriched uranium

HLW High-level radioactive waste

IFR Integral Fast Reactor - a fast reactor system, including metal-fueled, sodium-cooled fast reactors, and a unique fuel cycle integrated into reactor deployment

LD lethal dose

LEU Low enriched uranium

LLW Low-level radioactive waste

IAEA International Atomic Energy Agency, established in 1957.

INFCE International Nuclear Fuel Cycle Evaluation

MB Megabytes

MOX Mixed oxide fuel

NAS National Academy of Sciences

NASAP Nonproliferation Alternative Systems Assessment Program

NEPA National Environmental Policy Act (P.L. 91-190), signed into law by President Nixon on January $1,1970$.

NRC Nuclear Regulatory Commission, established by the Energy Reorganization Act of 1974. Its regulations are found in 10 Code of Federal Regulations, Parts 1 to 199. 
NSC National Security Council

OMB Office of Management and Budget, called Bureau of the Budget before 1970.

OTA Office of Technology Assessment, an office of the Congress from 1974 to 1995.

PD Presidential Directive

PDD Presidential Decision Directive

P.L. Public Law, since 1957, all Congressional actions have been designated as Public Law X-Y where $\mathrm{X}$ is the number of the Congress and $\mathrm{Y}$ is a sequential number. The current Congress (2011-2012) is the $112^{\text {th }}$.

R\&D Research and development

RG Reactor-grade

SNM Special nuclear material, first used in Atomic Energy Act of 1954 [AEA1954]

SSNM Strategic special nuclear material, see 10CFR70, 73, 74, 76.

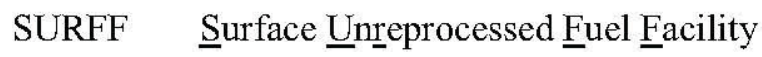

TRU Trans-uranic elements (beyond uranium in the Periodic Table)

WG Weapons-grade

U.S. United States

USC "The United States Code is the codification by subject matter of the general and permanent laws of the United States based on what is printed in the Statutes at Large. It is divided by broad subjects into 50 titles and published by the Office of the Law Revision Counsel of the U.S. House of Representatives." www.gpoaccess.gov/uscode/about.html. Some of those titles potentially relevant to this report's purpose are as follows:

5 Government Organization and Employees (has some laws on data classification)

22 Foreign Relations and Intercourse

40 Public Buildings, Property, and Works

42 The Public Health and Welfare

50 War and National Defense 
Potential External Constraints 


\section{FUEL CYCLE OPTIONS CAMPAIGN POTENTIAL EXTERNAL (NON-DOE) CONS TRAINTS ON U.S. FUEL CYCLE OPTIONS}

\section{INTRODUCTION}

The DOE Fuel Cycle Technologies Program will be conducting a screening of fuel cycle options in FY2013 to help focus fuel cycle R\&D activities. As part of this screening, performance criteria and go/no-go criteria are being identified. To help ensure that these criteria are consistent with current policy, an effort was initiated to identify the status and basis of potentially relevant rules, regulations, and policies that have been established external to DOE. As such rules, regulations, and policies may be beyond DOE's control to change, they may constrain the screening criteria and internally-developed policy.

This report contains a historical survey and analysis of publically available ${ }^{g}$ domestic $^{\mathrm{h}}$ documents that could pertain to external constraints on advanced nuclear fuel cycles. "External" is defined as public documents outside DOE. This effort did not include survey and analysis of constraints established internal to DOE. ${ }^{\mathrm{i}}$

This document does not address what will be proposed for the FY2013 screening of fuel cycle options. It only reports on what has been found in surveying external public domestic documents. DOE documents were included mostly to provide context in the key 1974-1981 time period as fuel cycle, waste management, and proliferation policies were changing.

In the summary and most of the main document, purple italics are used to differentiate statements of fact regarding contents of document versus the author's analysis thereof in any location for which confusion is a possibility.

This report explores questions such as Are there hard yes/no requirements regarding a maximum U-235 enrichment, allowability of separation of plutonium, separation of used fuel, and fast breeder reactors? How have these policy topics been defined and addressed? Because nuclear topics are interwoven, in searching for information on these specific matters, the author surveyed a wide range of nuclear-related documents, and, in the process, assembled considerable information. This proved sufficient to document other "common wisdoms" and topics, such as the spent fuel standard, second repository supposedly being east of the Mississippi, existence of any criteria for U233, and how U.S. nuclear energy policies have evolved from Fermi's meeting on possibilities of commercial nuclear power plants on April 26, 1944 [text of the meeting minutes appears in Koch2008] to present. References are denoted in blue text to avoid confusion.

As this is a relatively unusual report, please note its organization, as follows:

g. Currently classified documents were not reviewed. It is possible that additional requirements, or explanation of public requirements, could exist in classified documents. Regarding the former, the author notes that when previously classified documents have been subsequently declassified (e.g., Carter1977, Bush1992) there were no additional requirements identified; indeed, maximization of policy impacts requires public disclosure and indeed there were public statements within a few days of the classified directives in 1977 and 1992 that contained the salient policy points.

h. A few IAEA documents were also assessed. IAEA documents have legal or regulatory force in the U.S. when adopted by U.S. entities, e.g., U.S. moves toward safeguards applied to U.S. non-military facilities. Also, IAEA criteria influence U.S. criteria, e.g., most of the criteria establishing safeguarding thresholds in INFCIRC/225 have been adopted in 10 CFR74.

i. While some DOE documents were analyzed as part of this effort, there was not a systematic assessment to identify internally generated policy. 
- Acronyms and agencies: Includes brief explanation of CFR (Code of Federal Regulations), PL (Public Law), USC (United States Code), FR (Federal Register), General Accounting Office (GAO) (later renamed), Office of Technology Assessment (OTA), Congressional Research Service (CRS). GAO, OTA, and CRS all report (or reported) to Congress.

- Chapter 1: Introduction

- Document pyramid to help understand the roles of different types of documents.

- Explanation of which types of documents were and were not reviewed in this report.

- Explanation of what laws, regulations, and policy statements are, and are not. For example, the legal force and durability of a policy statement, such as Carter's PD/NSC-8 in 1977, depends on whether there are laws granting or delegating authority.

- How are some key words defined in law?

- Chapter 2: Analysis

- Analysis of specific topics: (1) Recycle versus once-through fuel cycles (using GAO's 1981 terminology as it outlined policy differences for Congress at a key point in time), (2) U235 criteria thresholds at $20 \%, 10 \%$, and $5 \%$, (3) Lack of U233 criteria, (4) Plutonium criteria thresholds, (5) pure plutonium and separated plutonium, (6) TRU other than plutonium, (7) What is the "spent fuel standard" and does it have legal or regulatory force?, (8) When did the federal government begin offering to take used fuel from utilities?, (9) Why is spent fuel not defined as HLW?, (10) Which candidate geologic repositories and "east of the Mississippi"?, and (11) When and why were fissile breeding ratio and transuranic conversion ratio defined?

- An integrated timeline of key events and documents. The timeline addresses breeder reactors, reprocessing, plutonium separation, and uranium enrichment; these matters are interwoven and many events and documents are relevant to more than one of the topics.

- A table comparing relevant topics in the late 1970 s, early 1990 s, and now. This is provided to give the reader yet another way of integrating the information: how specific topics have evolved over time in a single table.

- Chapter 3: List of References

- Chapter 4: Text extracted verbatim from documents, sometimes with explanations or observations added (in italics if needed to differentiate between the author's explanations and the original text).

\subsection{Scope Provided by Management}

Objective: Investigate key "common wisdom" commercial fuel cycle requirements to determine origin, history, basis, and status.

Specifically assigned topics: separated plutonium, reprocessing, breeders, use of high-enriched uranium (HEU)

\section{Approach}

- Be factual. 
- Track down primary references and assemble catalog of them.

- Note interrelationships among topics - implicit or explicit, correct or incorrect. For example, sometimes "breeders" have been taken to be synonymous with "fast reactor". Thus, exact language is important. Indeed, sometimes the language itself has a historical context, i.e., what something meant then when the statement or whatever was written isn't the same as it means now. This led to portraying what was found in multiple ways in Chapter 2.

- The product is a list, description, and catalog of official government legislation, executive orders, policy statements, etc. Chapter 3 is a list of references. Chapter 4 contains text extracted verbatim from the more important references. A database of $\sim 280$ documents $(780 \mathrm{MB})$ is also available.

- Restrict analysis to federal level, ignore state and local.

- If judicial interpretations or reviews have occurred on such statements, include them. The one relevant case found is the owners of the terminated Barnwell reprocessing plant sued the US Government to attempt to recoup their investment. They failed.

\section{Challenges}

- Proving the positive (finding a document stating something) is possible.

- Proving the negative (asserting the lack of a document stating something) is very difficult if not impossible. The author searched by title through all GAO and OTA reports ( $\sim 2000$ and hundreds of reports respectively) relevant to energy, nuclear, waste. ${ }^{j}$ He examined all NRC regulations in the CFR (10CFRxx). He searched the electronic searchable catalogs for presidential libraries of R. M. Nixon, G. R. Ford, J. E. Carter, R. W. Reagan, G. W. H. Bush, W. J. Clinton, and G. W. Bush, and the American Presidency Project at http://www.presidency.ucsb.edu/index.php. He searched the internet.

- Capturing time dependence of statements where relevant. For example, sometimes laws change with time such as the Nuclear Waste Policy Act, which has had many amendments.

\subsection{Types of Documents}

In simplest terms, this survey considered three types of documents.

1) Policy documents such as presidential statements or federal laws.

2) Policy assessment documents such as reports from the GAO, OTA, etc.

3) Technical (or mostly technical) documents such as NRC regulations and the 1980 report of the Nonproliferation Alternative Systems Assessment Program.[NASAP1980].

For present purposes, type-3 technical documents stand on their own. Neither "1" or "2" type documents are written for a technical audience and the typical absence of clear definitions and explanations is often frustrating Since type-1 documents rarely (if ever) include rationale or interpretations, the ideal situation is when both type-1 and type-2 documents can be located, analyzed, and extracted in this report. A good example of this is the Nuclear Waste Policy Act of 1982 (NWPA). The text of NWPA (type-1) is included in the catalog of documents assembled electronically. Text from

$\mathrm{j}$. There is no database of all Congressional Research Service (CRS) reports. So, a comprehensive and systematic search of those reports was not possible. 
NWPA is extracted in chapter 4. Various GAO and OTA assessments (type-2) of the NWPA are also included in the catalog and extracted in chapter 4. When it comes to summarizing NWPA, mostly type-2 documents are quoted as the language is clearer and more direct. NWPA rarely says why a specific provision is included; the current author often depends on GAO or OTA to provide rationale.

Also, when something is not stated in a type-1 document, of course, one can't quote the absence of something. Rather than depend on the current author's analysis of the absence of something (absence of rationale, absence of prohibition, etc.), the author has included a type-2 document noting the absence.

Sometimes the type-1 document has not been found, leaving only type-2 documents to describe its contents, rationale, purpose, or effects. A good example is the administration of President $G$. H.W. Bush blocking the attempt in 1992 to send slightly used fuel from the closed Shoreham nuclear plant on Long Island to Cogema for reprocessing. Repeated attempts have not found any type-1 documents regarding the action, not even a title or what entities may have written what documents. The relevant type-2 documents do not cite a specific type-1 document. So, we are left with only type-2 documents.

More broadly, GAO and OTA (type-2 documents) have maintained a complete, comprehensive, and searchable catalog of all reports; whereas AEC/ERDA/DOE has not. Presidential libraries differ in their completeness; none systematically include documents from federal agencies other than the White House itself.

Figure 1 shows a hierarchy of documents. This is an aid to the reader, to help guard against interpreting a lower-level statement to incorrectly be a high level statement.

Some of the boxes in the diagram are not relevant to this exercise, except for context and completeness. For example, there is nothing in the Constitution that explicitly addresses any of the fuel cycle basis topics and it is unlikely there are Congressional Budget Office (CBO) rules on such topics. However, there may be personal agreements or committee statements that are relevant; these, however, were not searched as they do not have legal or regulatory force. Such statements could make such agreements or statements a useful source for clarifying the meaning of words and phrases in the actual laws, lacking any court rulings that have already officially clarified such words/phrases." 


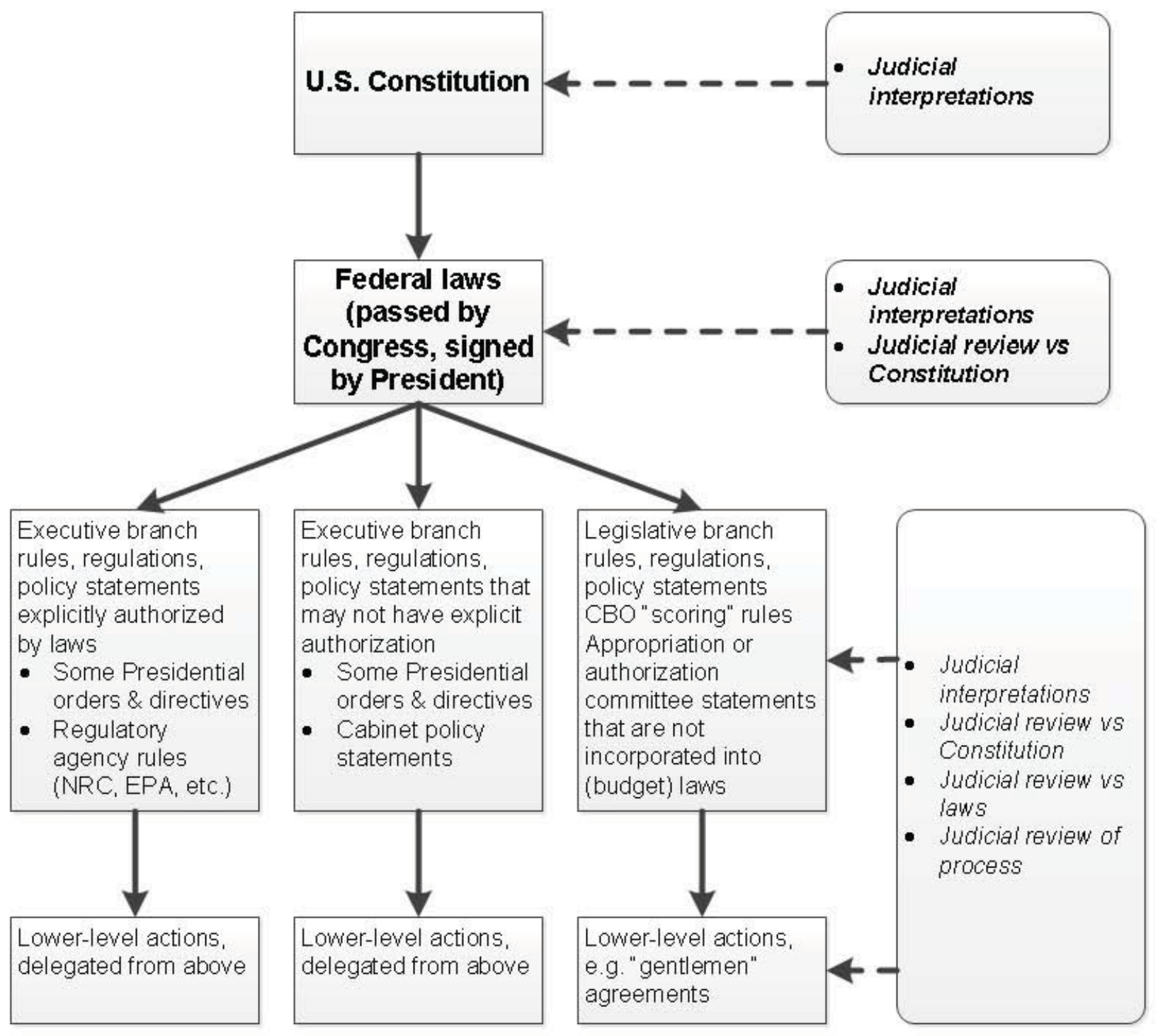

Figure 1. Document hierarchy.

The following types of documents were reviewed for this report. Electronic copies were collected, except for a few books.

- Law - document passed by both houses of Congress and either signed by the president or passed over his veto. A dozen laws appeared relevant to the task and were reviewed; they are listed in chronological order in the Table of Contents.

- Regulation - a document promulgated by an entity as authorized by law. NRC regulations directly pertaining to fuel cycle matters were reviewed. Regulations pertaining to information classification, export/import, and launching of space craft using radioactive power sources were not systematically reviewed.

- Policy statements (other than laws) - a statement by one or more members of the executive or legislative branches of government that articulates the intent to follow a particular course of action. Unless authorized by law, a policy statement does not have the direct force of law. See 
http://www.heritage.org/research/reports/2001/02/the-use-and-abuse-of-executive-orders-andother-presidential-directives.

- Public presidential statements - these include radio addresses, message to Congress, speeches.

- Reports - by GAO, OTA, CRS, DOE, AEC, National Academy of Sciences, etc.

- Books - by various authors with diverse viewpoints. One reason was to examine lists of references to identify potentially relevant primary references.

The following types of documents were not systematically reviewed.

- Budget Guidance - instructions by House or Senate or both in budget laws or continuing resolutions

- Regulatory Guidance - a statement by a regulatory agency that explains in more detail (than the regulation itself) how an applicant or licensee should show compliance with the regulation.

- Judicial ruling - in the current context, a decision by a federal judge regarding a law or regulation or regulatory agency decision relevant to a fuel cycle question.

- Treaties - agreements among countries. Some IAEA treaties like the Non-Proliferation Treaty were analyzed.

\subsection{Laws, Regulations, Policy Statements, Guidance, Judicial Reviews, and Treaties}

For present purposes, we must differentiate among laws, regulations, policy statements, guidance, judicial reviews, and treaties as follows:

- Law - document passed by both houses of Congress and either signed by the president or passed over his veto. This includes federal spending laws (budgets, "continuing resolutions"), which can impose restrictions on spending or require reports to be prepared. Laws can establish policies.

- Regulation - a document promulgated by an entity as authorized by law. NRC regulations denote which laws authorize each regulation or part of regulation. The key laws that impact fuel cycles authorized first the Atomic Energy Commission (AEC) and later the Nuclear Regulatory Commission (NRC) to make decisions; they did not authorize the president. Exceptions to this tendency are (a) national security laws tend to grant decisions on classification and control of such information to the president and his designees, ${ }^{\mathrm{k}}$ (b) the president and his designees have authority on many import/export matters, [for example, see Atomic Energy Act of 1954, sec. 123] and (c) approval by the president or the president's science advisor is required for the launch of space craft using radioactive power sources [DOE2008], e.g., Pu238 radioisotope generators. (These three areas of exceptions were not studied in this effort.) The president nominates NRC commissioners, subject to Senate confirmation and with the restriction that no more than three of the five being the same political party.[EnergyReorganizationAct1974] The President designates which of the commissioners serves as its Chairman.[EnergyReorganizationAct1974] As NRC commissioners have staggered terms, over time, a president can slowly change the mix of NRC commissioners.

k. The current author notes that during his most recent formal security training, the laws granting the authority of the president and DOE to classify material were explicitly noted. 
- Policy statements (other than laws) - a statement by one or more members of the executive or legislative branches of government that articulates the intent to follow a particular course of action. Unless authorized by law, a policy statement does not have the direct force of law. ${ }^{1}$ See http://www.heritage.org/research/reports/2001/02/the-use-and-abuse-of-executive-orders-and-otherpresidential-directives.

In the fuel cycle domain, the best example of this claim is that the Clinch River Breeder Reactor (CRBR) project continued six years after President Carter's PD/NSC-8 statement of 1977, then was terminated not directly because of Carter's policy statement but because of a 56-40 Senate vote in 1983 to terminate funding.[NWeek1983] Carter's policy influenced the policy debate, and in that sense, had an impact even after he left office. ${ }^{\text {m }}$

The seeds for Barnwell's demise were sown in 1974 when the "AEC determined that any decision to permit nuclear fuel reprocessing on a large scale would require an environmental impact statement under Section 101(2)(c) of the National Environmental Policy Act (U.S.C. 4332(2)(c))."'[CRS2008] In 1977, the "NRC issued an order terminating the proceedings on the Generic Environmental Statement on Mixed Oxide Fuel and most license proceedings relating to plutonium recycling. It stated, however, that it would reexamine this decision after two studies of alternative fuel cycles were completed." [CRS2008] In 1981, "Convinced that the project could not proceed on a private basis and that reprocessing was commercially impracticable, Allied halted the Barnwell project."[CRS2008] The federal government's argument was that it was legal for the AEC to stop proceedings, not because of Carter's policy, but because of the broad authority given to the AEC under the Atomic Energy Act of 1954.[AEA1954] The federal government also noted that Barnwell's owners could have filed a petition to restart the hearings after Reagan undid Carter's policy, but the owners did not.[Courtfiling1988]

Similarly, President Clinton's analogous directive of September 1993 did not directly terminate either EBR-II or the Fast Flux Test Facility (FFTF). DOE decided to deactivate FFTF in December 1993 and it went into standby condition in January 1997. EBR-II was terminated by Congressional withdrawal of operating funds in August 1994.[NuclearNews2004]

On the other hand, Presidents do have authority to approve or stop certain export/import activities and it was on that basis that President G. H. W. Bush stopped Long Island Power Authority's attempt to reprocess its used fuel with Cogema.[CRS2008]

Changes in policy from one president to the next reflect lack of consensus on a topic. In this sense, the policy on uranium enrichment levels appears to reflect a consensus; policies on separation of plutonium or used fuel and policy on breeder reactors does not.

Sometimes, executive orders or other presidential decisions are later codified into law. For example, several Truman and Eisenhower executive orders were codified in the Atomic Energy Act of 1954.[AEA1954] And, years after Nixon established the Environmental Protection

1. A reviewer of this report commented that the report emphasizes how a president can stop things, even though he does not have the ability to make law. Yet, at least in the fields studied for this report, a president's direct authority is indeed in the negative, especially import/export control a president can block import/export but cannot cause such things to happen. A president can propose budgets but only Congress can authorize spending. Of course a president can propose policies and priorities, as is captured in this document. But, with regard to the original emphasis of this report finding yes/no criteria a president mostly has self-authority only on the "no" side. Most of the "yes" side authority is signing laws passed by Congress, including budgets and continuing budget resolutions.

$\mathrm{m}$. Of course, Carter's policies were not the only factors in the termination of Clinch River. As noted by reviewer Charles Forsberg, reprocessing and Clinch River were also impacted by increased discoveries of uranium, suggesting that uranium prices were unlikely to increase for considerable time. 
Agency by reorganizing several individual environmental agencies (each authorized by law) into a single agency (accepted by Congress at the time); his action was codified into law.

Often, only press release summaries of presidential directives are public. Carter's PD/NSC-8 of 1977 was declassified seventeen years later in 1994. So, GAO and CRS documents in the 1970s and 1980s do not cite it. They do cite Carter's analogous public statement. Parts of Reagan's NSDD-39 in 1982 were declassified in 1992, the rest remain classified. Clinton's PDD-13 of 1993 is still classified.

- Guidance - a statement by a regulatory agency that explains in more detail (than the regulation itself) how an applicant or licensee should show compliance with the regulation. Guidance documents were not systematically reviewed for this report.

- Judicial ruling - in the current context, a decision by a federal judge regarding a law or regulation or regulatory agency decision relevant to a fuel cycle question. A judge or panel of judges could reject a law or regulation on the basis that a higher-level legal document or precedent conflicts with it. For example, regulations in other fields have been invalidated if judges decide that there is inadequate basis in law granting the regulatory agency the power to issue the regulation. A regulatory decision can be rejected if procedures or the regulation in question were not appropriate. Judicial rulings were not systematically reviewed for this report, although a lawsuit regarding Barnwell was considered.

- Treaties - agreement among countries. These were not reviewed for this report, except for some of the treaty between the US and the IAEA.

\subsection{How are some key words defined in laws and regulations?}

Where a definition appears in a law, it is given. Otherwise, definitions are taken from regulations.

Atomic energy - "all forms of energy released in the course of nuclear fission or nuclear transformation."[AEA1954] Same definition appears in regulation 10CFR50.

Civilian nuclear power reactor - "means a civilian nuclear power plant required to be licensed under section 103 or 104b. of the Atomic Energy Act of 1954 (42 USC 2133, 2134(b))."[NWPA1982] See also "commercial nuclear power reactor" and "reactor" below.

Commercial Nuclear Power Reactor - "any unit of a civilian light-water moderated utilization facility required to be licensed under section 103 or 104b. of the Atomic Energy Act of 1954 (42 USC 2133 or 2134(b))."[Low-Level Radioactive Waste Policy Act of 1985 (P.L. 99-240)] See also "civilian nuclear power reactor" above and "reactor" below.

Disposal - "means the isolation of waste from the biosphere, with no intention of retrieval, such as by land burial"[Low-Level Radioactive Waste Policy Act of 1985 (P.L. 99-240)]

Disposal - "the emplacement in a repository of high-level radioactive waste, spent nuclear fuel, or other highly radioactive material with no foreseeable intent of recovery, whether or not such emplacement permits the recovery of such waste."[NWPA1982]

Disposal - "Disposal means permanent isolation of spent nuclear fuel or radioactive waste from the accessible environment with no intent of recovery, whether or not such isolation permits the recovery of such fuel or waste. For example, disposal of waste in a mined geologic repository occurs when all of the shafts to the repository are backfilled and sealed."[40CFR191.02] 
Low enriched uranium (LEU) - the author has not found any legal definition of "LEU", but regulation 10CFR50 defines LEU fuel as "fuel in which the weight percent of U-235 in the uranium is less than $20 \%$."

Low-level waste - "radioactive waste other than:

(i) Waste generated as a result of defense activities of the federal government or federal research and development activities;

(ii) High-level waste such as irradiated reactor fuel, liquid waste from reprocessing irradiated reactor fuel, or solids into which any such liquid waste has been converted;

(iii) Waste material containing transuranic elements with contamination levels greater than ten (10) nanocuries per gram of waste material;

(iv) By-product material as defined in section 11e.(2) of the "Atomic Energy Act of 1954," as amended November 8, 1978; or

(v) Wastes from mining, milling, smelting or similar processing of ores and mineral-bearing material primarily for minerals other than radium."[Low-Level Radioactive Waste Policy Act of 1985 (P.L. 99-240)]

Low-level radioactive waste - "radioactive material that-

(A) is not high-level radioactive waste, spent fuel, transuranic waste, or by-product material as defined in section 11e(2) of the Atomic Energy Act of 1954 (42 USC 2014(e)(2))' and

(B) the Commission, consistent with existing law, classifies as low level radioactive waste."[NWPA1982]

Highly enriched uranium (HEU) - the author has not found any legal definition of "HEU", but regulation 10CFR50 defines HEU fuel as "fuel in which the weight percent of U-235 in the uranium is $20 \%$ or greater. Target material, special instrumentation, or experimental devices using HEU are not included."

High-level radioactive waste - see section 2.1 .9 of this report.

"(A) the highly radioactive material resulting from the reprocessing of spent nuclear fuel, including liquid waste produced directly in reprocessing and any solid material derived from such liquid waste that contains fission products in sufficient concentrations; and

(B) other highly radioactive material that the Commission, consistent with existing law, determines by rule requires permanent isolation."[NWPA1982]

Note that the above definition defines HLW by its source, not by its characteristics. However, in 1987, the NRC started rulemaking to move from source-based to characterization-based definition of HLW (NRC 1987), but then dropped the effort due to lack of need. At that time, they wrote,

"Wastes which have historically been referred to as HLW (i.e. reprocessing wastes) are initially both intensely radioactive and long-lived. These wastes contain a wide variety of radionuclides. Some (principally Sr-90 and Cs-137) are relatively short-lived and represent a large fraction of the radioactivity for the first few centuries after the wastes are produced. These nuclides produce significant amounts of heat and radiation, both of which are of concern when disposing of such wastes. Other nuclides, including C-14, Tc-99, I-129, and transuranic nuclides, have very long half-lives and thus constitute the longer-term hazard of these wastes. Some of these nuclides pose 
a hazard for sufficiently long periods of time that the term "permanent isolation" is used to describe the type of disposal required to isolate them from man's environment. The commission considers that these two characteristics, intense radioactivity for a few centuries followed by a long-term hazard requiring permanent isolation, are key features which can be used to distinguish high-level waste from other waste categories."[NRC1987]

Reactor - the author has not found any legal definition of "reactor" or "nuclear reactor", but see "commercial nuclear power reactor" and "civilian nuclear power reactor" that are defined above, and also note that regulation 10CFR50 defines "nuclear reactor" as "an apparatus, other than an atomic weapon, designed or used to sustain nuclear fission in a self-supporting chain reaction."

Repository - "means any system licensed by the Commission that is intended to be used for, or may be used for, the permanent deep geologic disposal of high-level radioactive waste and spent nuclear fuel, whether or not, such system is designed to permit the recovery, for a limited period during initial operation, of any materials placed in such system. Such term includes both surface and subsurface areas at which high-level radioactive waste and spent nuclear fuel handling activities are conducted."[NWPA1982]

Reprocessing and recycling - There are no known legal or regulatory definitions. The NRC staff noted that "Existing regulations 10 CFR Parts 20, 50, 51, 60, 63, 70 and 72 use the term "reprocessing" without a definition. Such definitions will need to be developed to describe both reprocessing and reprocessing facilities for 10 CFR Chapter I."[SECY-09-0082]

Source material - "(1) uranium, thorium, or any other material which is determined by the Commission pursuant to the provisions of section 61 to be source material; or (2) ores containing one or more of the foregoing materials, in such concentration as the Commission may by regulation determine from time to time."[AEA1954]

Special nuclear material - "(1) plutonium, uranium enriched in the isotope 233 or in the isotope 235 , and any other material which the Commission, pursuant to the provisions of section 51, determines to be special nuclear material, but does not include source material; or (2) any material artificially enriched by any of the foregoing, but does not include source material."[AEA1954] The NRC staff has noted that "americium (Am), neptunium (Np), and others are currently not regulated or treated as other fissile or SNM material."[SECY-09-0082]

Spent nuclear fuel - "fuel that has been withdrawn from a nuclear reactor following irradiation, the constituent elements of which have not been separated by reprocessing."[NWPA1982]

Transuranic waste - "material contaminated with elements that have an atomic number greater than 92 , including neptunium, plutonium, americium, and curium, and that are in concentrations greater than 10 nano-curies per gram, or in such other concentrations as the Nuclear Regulatory Commission may prescribe to protect the public health and safety."[AEA1954] 


\section{ANALYSIS}

The author has found no U.S. public external document that imposes a legal or regulatory yes/no requirement on commercial nuclear fuel cycles with regard to any particular uranium enrichment, separation of plutonium or transuranic (TRU), purity of plutonium, separation of used fuel, breeder reactors, or recycling versus once-through/direct disposal.

The author's analysis of U.S. public external documents is that those documents suggest that each of these topics (as well as others) could impact the risk of regulatory disapproval, likelihood of continuing funding and policy support, and/or cost if built and operated.

This chapter provides the author's analysis of the $\sim 280$ documents and thousands of pages he has reviewed. It has four sections.

- Analysis of specific topics.

- An integrated timeline of key events and documents. The timeline addresses breeder reactors, reprocessing, plutonium separation, and uranium enrichment; these matters are interwoven and many events and documents are relevant to more than one of the topics.

- A table comparing relevant topics in the late 1970 s, early 1990 s, and now. This provides another way to see how specific topics have evolved.

- A brief summary of the evolution of cost estimates.

\subsection{Analysis of Specific Topics}

This section contains analysis of the following specific topics:

1. Recycle versus once-through fuel cycles (using GAO's 1981 terminology [GAO-EMD-81-78] as it outlined policy differences for Congress at a key point in time)

2. U235 criteria thresholds at $20 \%, 10 \%$, and $5 \%$

3. Lack of U233 criteria

4. Plutonium criteria thresholds

5. TRU other than plutonium

6. Pure plutonium and separated plutonium

7. What is the "spent fuel standard" and does it have legal or regulatory force?

8. When did the federal government begin offering to take used fuel from utilities?

9. Why is spent fuel not defined as HLW?

10. Candidate geologic repositories and "east of the Mississippi"

11. When and why were fissile breeding ratio and transuranic conversion ratio first defined? 


\subsubsection{Recycle versus once-through fuel cycles}

These two classes of fuel cycle options need to be considered historically. The three periods are roughly 1944-1974, 1974-1981, and 1981-present. One particular reference discusses various historical events.[Andrews2008] Note that this subsection 2.1.1 discusses the time-wise summary of recycle vs. once-through; the partially parallel time-wise discussion in the summary includes recycle vs. oncethrough and other issues not in section 2.1.1.

\section{4 to $\sim 1974$ - a consensus on recycling, fast breeders, and no requirement for used fuel retrievability}

The first known detailed discussions about commercial nuclear power in this context occurred on April 26, 1944.[Koch2008] E. Fermi and others discussed the limited availability of uranium and stated that fast breeder reactors would be needed eventually, accompanied by recycling of used fuel.[text of the meeting minutes appears in Koch2008] Over time, this consensus view of breeding and recycling was increasingly explicit and formal, first by the AEC [AEC1962] and later at the presidential level recycling[Johnson1966] and the breeder.[Nixon 1971] Until the Indian plutonium bomb test on May 18, 1974, all reports reviewed suggest a consensus - eventual transition to fast breeder reactors and disposal of the residual HLW after reprocessing. Indeed, spent fuel was deliberately not defined as HLW in this time period.[GAO-EMD-77-41]

Thirty years of consensus ended on May 18, 1974 when India tested a plutonium-based bomb.

- 'The ambiguous Indian 'peaceful' explosion of 1974 was a reminder of the nuclear weapons potential of a growing number of states. At international tension points, rival insecure or ambitious states confront each other. If one or more states overtly 'go nuclear' in the near future, there is risk of a chain reaction of nuclear commitments by imitators or rivals. At this crucial time, nuclear power is spreading and bringing with it growing basic nuclear capabilities. In the United States and in other countries with nuclear power programs, technical decisions are impending whether to proceed with plutonium reprocessing and recycle and with breeder development, which could constitute a watershed for proliferation."[Ford/MITRE1977]

- "While concern about the relationship between civilian nuclear power and research programs and the proliferation of nuclear weapons is not new, international attention to this problem has increased in recent years. There are a number of reasons for this heightened concern, including in particular the Indian nuclear explosion of 1974, which involved material and facilities supplied for peaceful purposes."[NASAP1980]

- 'India's 1974 explosion of a nuclear device caused the United States to reassess its nonproliferation controls because the plutonium used in the explosion was produced, albeit indirectly, with U.S. assistance. In order to reduce the risk of further proliferation, the Congress enacted the Nuclear Non-Proliferation Act of 1978 [NNPA1978] and provided stronger controls over the export of U.S. nuclear technology. In passing the act, the Congress found that the proliferation of nuclear weapons posed a grave threat to the security of the nation and an urgent and imperative need existed to prevent further proliferation. The Congress wanted effective and efficient controls established on the use of nuclear material and technology exported for peaceful purposes that would provide greater assurance against the diversion of materials and technology essential to the creation of, or the ability to create, nuclear weapons."[GAO-RCED-87-150]

\section{$\sim 1974$ to $\sim 1981$ - a period of transition}

Note how policy changed and how it was implemented. It was not a simple matter of either Presidents Ford or Carter issuing a presidential policy with legal authority. 
In September 1976, the U.S. was "the world's leading nuclear exporter" which had supplied about $70 \%$ of the world's nuclear reactors and much of the related fuel and technology."[GAO-ID-76-60] Reading through reports in this time period, it is clear that first Ford and then Carter believed that the U.S. market dominance meant that the world would follow our example if we put reprocessing and breeders on hold.

President Ford put plutonium recycling and breeder reactors on hold on October 28, 1976 to set an example.

On April 7, 1977, President Carter issued his statement [Carter1977] against breeders and reprocessing, again to set an example as the U.S. led the world in technology exports. Although this statement did not have legal force, it appears to have induced four key 1977 events.

- NRC terminated proceedings for the GEIS for MOX fuel and plutonium recycling, stalling the Barnwell plant for separation of used PWR and BWR fuel. At the time, the NRC stated this was a pause until INFCE and NASAP were completed, but the proceedings were never resumed, likely because the political and business support for Barnwell had declined.

- In October 1977, "the DOE announced that the Federal Government would begin accepting and taking title from utilities to spent nuclear fuel that previously was to be reprocessed"[GAO-EMD78-97, GAO1978 Barnwell testimony], thereby undercutting Barnwell's rationale and market.

- The FY1978 budget proposal from the Carter administration called for a "Surface Unreprocessed Fuel Facility (SURFF)" to "provide safe and economical storage of spent fuel."[GAO-EMD-7741] This is the first plan found for what is now called interim storage.

- DOE declassified the "fact that a nuclear test was conducted using reactor grade plutonium and that it successfully produced a nuclear yield."[RDD-8] This declassification called attention to reactor-grade plutonium, which would have been produced by Barnwell.

In 1980, both international INFCE and domestic NASAP reports were published. Thereafter, one approach to fuel cycles continued the once-through path set in 1977, while the breeder/recycling approach was also continued. To some degree, those who put all plutonium (pure and impure) in the same proliferation-resistance category as HEU align with the first approach. Those who differentiate impure plutonium (spiked, co-process, etc.) from pure plutonium often align with the second approach.

The range of opinions about proliferation (it is just institutional vs. it is so technical that we have to ban breeders and plutonium) was recognized by NASAP1980, which stated an in-between position:

"The problem of proliferation, like all major national and international problems, is too complex to be solved by a single approach, technical or institutional. The NASAP report states that although the problem cannot be solved by technical means, it can be mitigated by technical means. It further states that technical and institutional approaches to the problem are related, though in diverse and complex ways from one fuel cycle to another, and that the combination of technical means and institutional arrangements can enhance the proliferation resistance of nuclear power systems."

n. A reviewer of this report asked, if the Indian test of May 18, 1974 was so significant, why did it take over two years for policy to change? This author does not claim to understand the relative speed of government policy changes. In this case, the resignation of President Nixon on August 9, 1974 and the fall of Saigon, South Vietnam, on April 30, 1975 could have distracted attention. Also, to compare, note that three years passed between Bush41's call for review of non-proliferation policy (June 15, 1989) and issuance of new policy (July 10,1992). The author's personal memory was that Governor Carter was raising nonproliferation policy in the 1976 campaign and he speculates that that may have helped induce President Ford to act a week before the 1976 election. 
Despite Carter's opposition to Barnwell and CRBR in budget negotiations with Congress,[Carter1979] Barnwell was not formally cancelled until October 15, 1981 and CRBR was terminated on October 26, 1983 by the Senate voting 56-40 to terminate funding. By 1983, the Nuclear Waste Policy Act of 1982 was in place and it removed waste management classification incentives to recycle [see its text and SAND2010-6335] and prohibited use of the nuclear waste fund for reprocessing by not including it in what uses are allowed,[GAO-08-483] but in the pro-recycle direction it also included required spent fuel retrievability [GAO-EMD-81-78] and did not define "spent fuel" as HLW because of the potential for later reprocessing of spent fuel.[GAO-EMD-77-41]

\section{1 to present - two fuel cycle approaches debated; both partially in NWPA}

After the period of roughly 7 years in which Ford and Carter changed national direction, Congress eventually accepted that change to some degree, in part because of the cost of CRBR. NASAP1980 and INFCE1980 were published in 1980. NASAP (domestic) and INFCE (international) were large studies mostly triggered by Carter's change in reprocessing policy in 1977. Entities like the NRC paused (not canceled) activities such as licensing of the Barnwell reprocessing plant while awaiting these two reports.

The pre-1974 consensus for recycling (closed fuel cycles) was gone. The proliferation volume of NASAP (volume II) indicates the concern with closed fuel cycles was (and is) ...

"plutonium would appear in weapons-usable form and in forms that are relatively easy to exploit for weapons purposes. Without deployment constraints and suitable institutional arrangements, plutonium would appear in substantial and widespread inventories in bulk forms, which are inherently difficult to safeguard."[NASAP1980]

Another key paragraph from NASAP reads:

"All nuclear fuel cycles would entail some proliferation risks; there is no technical "fix".

Nevertheless, the light-water reactor fuel cycle with spent fuel discharged to interim storage does not involve weapons-usable material in any part of the fuel cycle and is a more proliferation-resistant nuclear power fuel cycle than other fuel cycles which involve highly enriched uranium or pure plutonium."[NASAP1980]

This above paragraph is technical analysis, not policy, regulation, or law. The first sentence seems to be often cited but not the second. The second sentence puts HEU and "pure plutonium" in the same category: less proliferation-resistant than once-through. It does not, however, compare impure or diluted plutonium with once-through. That comparison has been debated for over 30 years.

Thus, since 1981 or so there have been two approaches - direct disposal and recycle. One approach continues Carter's policy, explicitly re-established by Clinton. The other approach returned to recycling, similar to the first 30 years, but with one major and one minor change.

A waste management (minor) change - after 1980, waste management has sometimes considered either long-term above-ground storage or separation of $\mathrm{CsSr}$ to split the heat issues from the longevity issues.[GAO-EMD-81-78, OTA-O-171, OTA-BP-O-50]

A proliferation (major) change - after 1980, to mitigate proliferation concerns, one does not observe decision-maker-level proposals for fast breeder reactors recycling with pure plutonium - there have been fast convertor/burner reactors, co-processing, spiking, etc. to change one or more dimensions of the pre1974 option of fast breeder reactors/pure plutonium. Discussion of "pure plutonium" continues in a later subsection of this report. 
Table 1 of report. Two Approaches Have Been Articulated for 30 Years.

\begin{tabular}{|c|c|c|}
\hline $\begin{array}{l}\text { Names used by } \\
\text { GAO in } 1981 \text { or } \\
\text { NASAP in } 1980 .\end{array}$ & $\begin{array}{l}\text { "Throw-away", "Stow-away" [a], } \\
\text { "Once-through", "Direct disposal" }\end{array}$ & "Recycle", "Reprocessing" \\
\hline $\begin{array}{l}\text { Origin of } \\
\text { approach }\end{array}$ & $\begin{array}{l}\text { Consistent with, and catalyzed by, the } \\
1977 \text { policy change (no reprocessing, no } \\
\text { breeders) following the } 1974 \text { Indian } \\
\text { plutonium device. DOE first offered to } \\
\text { accept unprocessed used fuel in } 1977 .\end{array}$ & $\begin{array}{l}\text { Consistent with, and envisioned by, Fermi } \\
\text { et al in } 1944 \text {. [see text of } 1944 \text { memo in } \\
\text { Koch2008] Motivated by energy } \\
\text { resources. Focus appears solely on } \\
\text { uranium and plutonium for at least } 3 \\
\text { decades after } 1944 \text {. }\end{array}$ \\
\hline $\begin{array}{l}\text { What is } \\
\text { disposed? }\end{array}$ & Spent fuel directly disposed. & $\begin{array}{l}\text { Plutonium and uranium recycled, not } \\
\text { disposed. Some options include minor } \\
\text { actinide, Tc99, and I-129 transmutation } \\
\text { [GAO-RCED-94-16s] }\end{array}$ \\
\hline $\begin{array}{l}\text { Which geologic } \\
\text { environments have } \\
\text { been associated } \\
\text { with each } \\
\text { approach? }\end{array}$ & $\begin{array}{l}\text { The full range - basalt, salt dome, salt bed, } \\
\text { tuff, granite, clay, and borehole - have been } \\
\text { considered since mid-1970s. }\end{array}$ & $\begin{array}{l}\text { While recycle/reprocessing was the consensus } \\
\text { approach, salt dome and salt bed were the } \\
\text { predominant environments studied. }\end{array}$ \\
\hline $\begin{array}{l}\text { Which waste } \\
\text { parameters are } \\
\text { considered the } \\
\text { most important? }\end{array}$ & $\begin{array}{l}\text { A wide range of parameters have been } \\
\text { considered. DOE site cleanup program has } \\
\text { emphasized waste volume reduction rather } \\
\text { than heat and toxicity [GAO-03-593, OTA- } \\
\text { O-171] }\end{array}$ & $\begin{array}{l}\text { Heat output is more important factor than } \\
\text { physical volume of the waste [OTA-O- } \\
\text { 171] } \\
\text { Waste from reprocessed spent fuel is } \\
\text { simpler to dispose of.[GAO-EMD-81-78] }\end{array}$ \\
\hline $\begin{array}{l}\text { How approach } \\
\text { appears in } \\
\text { Nuclear Waste } \\
\text { Policy Act of } \\
\text { 1982, as } \\
\text { amended }\end{array}$ & $\begin{array}{l}\text { Inhibits waste classification credit for } \\
\text { waste longevity reduction via } \\
\text { reprocessing. [NWPA sec } 2 \text { and } \\
\text { SAND2010-6335] } \\
\text { Forbids use of waste fund for } \\
\text { reprocessing by not including it in what } \\
\text { uses are allowed.[GAO-08-483] }\end{array}$ & $\begin{array}{l}\text { Requires spent fuel retrievability with no } \\
\text { explicit time period,[NWPA sec 122] } \\
\text { motivated by potential for future fuel } \\
\text { recycling.[GAO-EMD-81-78] } \\
\text { Differentiation of "spent fuel" and "high } \\
\text { level waste" [NWPA sec 2] stems from the } \\
\text { possible recycle of "spent fuel". [GAO- } \\
\text { EMD-77-41] }\end{array}$ \\
\hline $\begin{array}{l}\text { Key Presidential } \\
\text { policy } \\
\text { statements } \\
\text { regarding } \\
\text { reprocessing }\end{array}$ & $\begin{array}{l}\text { "does not encourage the civil use of } \\
\text { plutonium and, accordingly, does not } \\
\text { itself engage in plutonium reprocessing } \\
\text { for either nuclear power or nuclear } \\
\text { explosive purposes."[Clinton 1993] }\end{array}$ & $\begin{array}{l}\text { "decision not to produce plutonium and } \\
\text { highly enriched uranium for nuclear } \\
\text { explosive purposes."[Bush1992] }\end{array}$ \\
\hline
\end{tabular}

Many reports make it explicit that those who oppose continuation of nuclear energy support once-through (as opposed to recycling) for as long as it takes to phase out nuclear energy, which many hope to be immediately. Of course, the converse is not true: support for once-through does not necessarily imply opposition to nuclear energy.

Those who support recycling generally support continuation of nuclear energy.

Indeed, instead of the formulation in Table 1, some frame the divide of opinion such that the choice is between anti-nuclear energy and pro-nuclear energy.

- "Pro-nuclear view: Existing safeguards provide sufficient protection against use of civilian nuclear energy for weapons - no country has ever used safeguarded nuclear material to make a 
bomb. Proliferation is a political issue, not a technical one - countries that are determined to get nuclear weapons will eventually do so, regardless of technology of civilian nuclear energy system."

- "Anti-nuclear view: All nuclear energy systems pose proliferation risks - relying on enrichment, producing plutonium (or at least producing neutrons that could be used to produce plutonium). These dangers cannot be substantially reduced without abandoning nuclear energy."

- "A middle view: Real nuclear energy contribution to spread of nuclear weapons can be reduced substantially by technical and institutional measures."[Bunn2004]

Consider some of the legal and regulatory statements on retrievability as a way to illustrate how complicated the details have become.

- NWPA section 122 states that a repository must be "designed and constructive to permit the retrieval of any spent nuclear fuel placed in such repository, during an appropriate period of operation of the facility, for any reason pertaining to the public health and safety, or the environment, or for the purpose of permitting the recovery of the economically valuable contents of such spent fuel. The Secretary [of Energy] shall specify the appropriate period of retrievability with respect to any repository at the time of design of such repository." Note that this retrievability pertains to only spent fuel and only during repository operation (pre-closure). This time period has subsequently been defined as 50 years.

- NWPA section 121.b.1.B states that NRC "shall include such restrictions on the retrievability of the solidified high-level radioactive waste and spent fuel emplaced in the repository as the Commission deems appropriate." Thus, the NRC can restrict retrievability.

- NWPA section 121.a requires the EPA to "promulgate generally applicable standards for protection of the general environment from offsite releases from radioactive material in repositories." The EPA has interpreted this as authorizing them to include a retrievability requirement at 40CFR191.14.f: "Disposal systems shall be selected so that removal of most of the wastes is not precluded for a reasonable period of time after disposal." This addresses all wastes, not just spent fuel.

\subsubsection{U235 enrichment criteria}

The author found no legal-regulatory prohibition against new commercial nuclear power plants with any particular uranium enrichment level. There are criteria thresholds at $20 \%, 10 \%$, and $5 \%$ so that cost (and perhaps project risk) would increase as a planned uranium enrichment level rose above each threshold.

$20 \%$ - Nonpower reactors operate today with U-235 above $20 \%$ but new licenses will not be granted to new nonpower reactors with U235 over 20\%.[10CFR50.64] It is explicit policy established in law to keep U235 fuel enrichment below 20\% for nonpower reactors. [EnergyPolicyAct 1992] Indeed, a U.S. High-Enriched Uranium (HEU)-fueled research reactor was cancelled in 1995.[OTA-ISS-615] However, the author finds no legal or regulatory requirement preventing new power reactors from being over $20 \%$. But, Nuclear Regulatory Commission (NRC) regulations do mandate increased material controls [10CFR74] and additional physical security and safety (e.g. number of armed guards during transportation) [10CFR73] for any facility if U235 is above $20 \%$. So, due to both law and regulations and long-established policy, U235 above $20 \%$ should be considered to have high legal-regulatory risk.

$10 \%$ - There is another step-function at $10 \%$ embedded in some NRC regulations but not policy nor law; in NRC regulations there are lower imposed restrictions below $10 \%$. 
$5 \%$ - There is a step-function at 5\%: (a) applications for exports over 5\% U235 have to be reviewed by both the NRC and the Executive Branch[10CFR110.41] and (b) facility precedents, i.e., what enrichment, fuel fabrication, and reactor facilities have and have not asked to be licensed for.

When and why did the $20 \%, 10 \%$, and $5 \%$ U235 enrichment thresholds arise? The "why" has not been found. The first mention of $20 \%$ found was in 1972 by the IAEA in one particular material protection context; this appears to have spread to the U.S. and to other contexts.

- The original Atomic Energy Acts of 1946 and 1954 did not define or use the term HEU, nor mention any specific uranium enrichment levels.

- The first mention found in IAEA documents of 20\% U235 is in "The Structure and Content of Agreements between the Agency and States Required in Connection with the Treaty on the NonProliferation of Nuclear Weapons," INFCIRC/153, June 1972.[INFCIRC/153] Section 37 has a threshold in the amount of U235 that can be exempted from safeguards, as follows.

(a) One kilogram in total of special fissionable material, which may consistent of one or more of the following:

- (i) Plutonium;

- (ii) Uranium with an enrichment of $0.2(20 \%)$ and above, taken account of by multiplying its weight by its enrichment; and

- (iii) Uranium with an enrichment below $0.2(20 \%)$ and above that of natural uranium, taken account of by multiplying its weight by five times the square of its enrichment;

- The same 1972 IAEA document shows a 5\% U235 threshold in section 80 regarding how to calculate the minimum frequency of safeguard inspections. That is the first mention found of $5 \%$ U235.

- NRC regulations uniformly define HEU as $20 \%$ U235. The NRC was created in 1974 . The author does not know when HEU first appeared in NRC regulations.

- The first IAEA physical protection criteria in 1975 included both the $10 \%$ and $20 \% \mathrm{U} 235$ criteria.

- Carter's PD/NSC-8 statement in 1977 uses the phrase "Highly Enriched Uranium" but does not define it.

\subsubsection{U233 enrichment criteria}

The author finds no laws or regulations establishing criteria as a function of U233 enrichment. 10CFR74 and 10CFR75 do not make safeguards for material containing U233 to be a function of U233 enrichment; safeguards are only a function of the amount of U233 present. U233 inventories over $2 \mathrm{~kg}$ are designated "strategic special nuclear material," the most safeguarded category. 10CFR75 puts NRC-licensed facilities under the inspection rules of the IAEA unless the U.S. Government or NRC deem otherwise.

ORNL has published a technical report arguing for a U233 enrichment threshold of $12 \%$ as analogous to the U235 20\% threshold, [Forsberg 1998] but the author finds no evidence that that U233 threshold has been adopted into regulatory or policy documents. NRC regulations updated as recently as December 2008 do not have a U233 enrichment step-function. The IAEA's International Nuclear Fuel Cycle Evaluation [INFCE1980] recognized the $12 \%$ threshold, but the author has not found this threshold in other IAEA documents. Because the IAEA was not the focus of the present work, relatively few IAEA documents were analyzed. 
Any Th/U233 fuel cycle will involve over $2 \mathrm{~kg}$-U233. Thus, any significant use of U233 might trigger full safeguards under current rules, independent of U233 enrichment. Little regulatory attention has been paid to U233, which explains the relatively incomplete state of U233 criteria. Were a Th/U233 fuel cycle to be a serious contender for an actual facility in the U.S., it is likely that more criteria would be established. For example, a threshold on U233 could be established that is analogous to $20 \% \mathrm{U} 235 / \mathrm{U}$ total. For now, the value of $12 \%$ U233/U-total has no regulatory basis in NRC or IAEA documents.

\subsubsection{Plutonium enrichment criteria}

Relative to U235, there is less clarity regarding possible step-functions regarding plutonium.

The IAEA exempts $\mathrm{Pu}$ with more than $80 \% \mathrm{Pu} 238 / \mathrm{Pu}$-total from being considered direct use material. [INFCIRC/225/Rev.4] This $80 \%$ Pu238 threshold does not appear in the analogous U.S. document 10CFR74, even though the material control and accounting requirements and thresholds are otherwise the same in the two documents. (The other difference regards the $100-\mathrm{rad} / \mathrm{hr}$ threshold separating "irradiated" and "unirradiated material", discussed later.) Thus, the current 10CFR74 invokes full safeguards on plutonium, regardless of the value of Pu238/Pu-total, if the mass of Pu exceeds $2 \mathrm{~kg}$.

The $80 \%$ threshold does appear in a few U.S. documents such as the Atomic Energy Act of 1954,[AEA1954] as amended, where it factors into some of the allowances for foreign distribution of plutonium and 10CFR 110.42 where $\mathrm{Pu}$ over $80 \% \mathrm{Pu} 238$ avoids some export restrictions and reviews. 10CFR73 states that MOX with over $20 \%$ plutonium would require NRC review on a case by case basis.

Note how the explanation of what materials are weapon usable has evolved. The fact that both uranium and plutonium provide pathways to a nuclear weapon were declassified on August 12, 1945, just days after the two bombings. The fact that Hiroshima was uranium and Nagasaki was plutonium was declassified in 1953; the fact that Nagasaki was Pu239 alone was declassified in 1965.[RDD-8] The ability of reactor-grade plutonium to be used to make a nuclear weapon was declassified in 1967. Only in 1992 did DOE declassify the statement that Np237 "can be used for a nuclear explosive device",[RDD-8] so it is unsurprising that Carter's 1977 statement only mentioned uranium and plutonium. Indeed, in the thousands of pages of laws, policy statements, and regulations surveyed for this report, there are extremely few that mention anything other than uranium, uranium isotopes, and plutonium.

When and why did the $80 \% \mathrm{Pu} 238$ threshold arise? This is the only domestic or international formal $\mathrm{Pu}$ isotope criterion yet found. The $80 \%$ threshold is that plutonium with $80 \%$ or more Pu 238 is described as less of a safeguard risk, presumably because of the heat generated by Pu 238 . The "why" of $80 \%$, as opposed to some other value, has not been found. The first mention of $80 \%$ found was in 1972 by the IAEA in one particular context; this appears to have spread to the U.S. and to other contexts.

- The first mention found in IAEA documents is in 1972, "The Structure and Content of Agreements between the Agency and States Required in Connection with the Treaty on the NonProliferation of Nuclear Weapons," INFCIRC/153, June 1972.[INFCIRC/153] Plutonium above $80 \% \mathrm{Pu} 238$ is exempted from safeguards in section 36 .

- The first mention found in US documents is in the 1974 additions to the U.S. Atomic Energy Act of 1954.[AEA1954] Section 54b was added, which contains the $80 \%$ Pu238 criterion with regard to export, i.e., only Pu with $80 \%$ or more Pu 238 could be exported to an entity other than the IAEA.

- The IAEA adopted the $80 \%$ Pu238 threshold in the context of physical protection between 1975 and 1978. (Recall that "physical protection" and "safeguards" are not the same.) It was not in the 
1975 first version of INFCIRC/225 on physical protection. It was added in Rev 1 in 1978 and retained thereafter, as was the $100 \mathrm{rad} /$ hour criterion. $^{\circ}$

Analysis: Thus, any significant use of Pu (over $2 \mathrm{~kg}$ ) might trigger full safeguards under current U.S. rules, independent of Pu isotopic enrichment. Were a fuel cycle with high Pu238/Pu-total to be a serious contender for an actual facility in the U.S., it is possible that the IAEA $80 \%$ threshold could be incorporated into U.S. rules.

Note the parallel situation of U233 and Pu. Under current 10CFR74, any amount of either material over $2 \mathrm{~kg}$ would trigger full NRC safeguard requirements; there are no isotopic clauses for U233/U-total or Pu238/Pu-total.

\subsubsection{Minor actinide enrichment criteria}

There are few statements and regulations regarding any TRU other than plutonium, or regarding the inclusion (or not) of other TRU with plutonium. For example, the NRC staff noted that "americium (Am), neptunium (Np), and others are currently not regulated or treated as other fissile or SNM material." [SECY-09-0082] DOE Order 410.2 on management of nuclear materials does cover these materials. TRU other than plutonium have not been focused on in the sort of policy-level documents relevant in this study. The only actinides at the policy-level are thorium, uranium, and plutonium.

In 1980, as noted in the previous subsection, NASAP1980 seems to have been the first to use the term "pure plutonium"; it stated that HEU and "pure plutonium" would have higher proliferation risk than once through. It did not make the same statement regarding impure (e.g. mixed with minor actinides or fission products) or diluted plutonium (e.g. mixed with uranium), but neither did it give any indication that such variations of closed fuel cycles would have as low proliferation risk as once through.

In 1982, "The fission products and the TRU elements (except for plutonium) are generally regarded as unusable wastes."[OTA-1982]

In 1992, DOE declassified the statement that Np237 "can be used for a nuclear explosive device" and that DOE has nonproliferation concerns about Np237.[RDD-8] The NRC has the authority regarding how different nuclear material would be regulated with respect to criticality, safeguards, etc. Even so, the NRC has defined only U-233, U-235, Pu-239, and Pu-241 as "fissile materials" regarding packaging and transportation of radioactive material as an example.[10CFR71.4] The only 10CFR studied that lists specific TRU isotopes other than Pu239 and Pu238 is 10CFR110, which restricts exports of all of the TRU, deuterium, tritium, and other materials.

In May 2009, the NRC staff noted a "gap" in their regulations.

"Gap - Existing regulations do not address security risks for other fissile material that can be separated in more advanced fuel cycle separations. Basis for Gap-Certain fissile elements such as americium (Am), neptunium (Np), and others are currently not regulated or treated as other fissile or SNM material. Such elements will be constituents in spent nuclear fuel and reprocessing facilities."[SECY-09-0082]

DOE's order 410.2 on Management of Nuclear Materials covers “americium-241, americium-243, californium, curium, deuterium, enriched lithium, neptunium-237, plutonium-238, plutonium-239-241,

o. In IAEA INFCIRC/225 and other documents, an external exposure dose rate of $100 \mathrm{rad} /$ hour (at a distance of 1 meter from the material) has been a criterion designating material sufficiently dangerous to handle that it can have less material protection than material with lower dose rate. This criterion is sometimes (and erroneously) referred to as the "spent fuel standard", which actually includes many criteria in addition to external exposure dose rate. 
plutonium-242, thorium, tritium, depleted uranium, normal uranium, enriched uranium, and uranium233."[DOE410]

\subsubsection{Pure plutonium and separated plutonium}

The concepts of "pure plutonium" and "no separation of plutonium" have not been found in regulations or laws. They do not have legal or regulatory definitions but they have had influence. There have been differing interpretations.

The issue of "plutonium separation" appears to have become mingled with the "spent fuel standard", "self-protecting", and "pure plutonium." The OTA and National Academy of Sciences (NAS) in 19931995 [OTA-ISS-615, NAS1994, NAS1995] used the term "spent fuel standard" in the context of disposition of excess weapons-grade plutonium (WG-Pu). The "spent fuel standard" is that if the WG-Pu can be put into a form as difficult to handle and extract plutonium from as is commercial spent fuel, the risk of the WG-Pu is no worse than what is already in storage; it has both chemical and radiological (dose rate) components.

"That separated plutonium from weapons rapidly be put into a form where it would take at least as much effort to recover the plutonium as it would to reprocess plutonium from the much larger stocks of spent fuel already existing worldwide. The report also concludes that once weapon plutonium has been converted to such a form - for example by mixing it with radioactive waste to create "artificial spent fuel," or by converting it to mixed-oxide fuel and partially burning it in a light-water reactor there is little point to proceeding to eliminate it entirely before addressing those stocks of spent fuel as well."[OTA-ISS-615]

The extensive OTA report in 1995 [OTA-ISS-615] dealt with the full range of proliferation issues. There is an entire section on fuel cycles. It is unclear to this author whether "separated plutonium" from a policy standpoint in that document meant (1) chemically pure plutonium or (2) plutonium possibly mixed with something else such as uranium or other TRU. Of course, it is possible that the OTA authors did not understand and/or care about the distinction as virtually the entire report dealt with PUREX, which is a specific aqueous separation approach that produces high purity plutonium and high purity uranium products.

- Arguing for the first interpretation ("separated plutonium" meant chemically pure plutonium) is seeming equivalence of no "separated plutonium" with the phrase "ban on the production of weapon-usable materials" and the context of the report, namely its focus on PUREX. Indeed, PUREX leads to pure plutonium. Also, the language in the earlier 1993 report, OTA-ISC-559, is a bit more stark as high enriched uranium and reactor-grade plutonium are discussed in such a way that implies the OTA was primarily thinking in terms of chemically pure plutonium, e.g., there is no mention of subsequent chemical processing if one obtained plutonium. Similarly, another 1993 report OTA-BP-ISC-115 links "plutonium" with the concept it can be used to make a "crude nuclear weapon" without further chemical processing and Figure 4-1 of that reference states the two pathways are "Enrich uranium to weapon grade" and "Reprocess to obtain pure plutonium."

- Arguing for the second interpretation ("separated plutonium" is an issue even if plutonium remains mixed with uranium or other TRU) is the claim that "Eliminating the production of separated plutonium would terminate exploration and exploitation of one fuel cycle that had been envisaged since the dawn of nuclear power: the recovery of plutonium from spent reactor fuel and the exploitation of that plutonium in either the current generation or a future generation of reactors." [OTA-ISS-615] This claim is only true if one bans separation of plutonium even if it is recovered with uranium and/or other TRU. Because the 1995 OTA authors cited the 1994 report 
OTA-BP-ENV-126 on the ALMR/IFR, they presumably were aware of the concept of

pyroprocessing plutonium with other transuranics, lanthanide fission products, and even $30 \%$

uranium in the product, followed by use of the product in the ALMR/IFR. This would suggest that

"self-protecting" plutonium was not an escape from no "separated plutonium" and therefore the second interpretation is correct, hence the claim that the no "separated plutonium" policy would forbid the fuel cycle noted above. However, by this time, the ALMR/IFR was described as a burner of excess plutonium, a pathway to destroy plutonium not exploit it,[OTA-BP-ENV-126] whereas this 1995 report's text on fuel cycles was in the context of breeders.

\section{Recent examples regarding the lack of definition of "separated"}

Recent examples continue to show the importance of, but lack of, the definition of "separated" as more recent documents expand the topic of "separated" from Pu to also U233. Consider these two documents:

1. "Global Nuclear Energy Partnership Technology Development Plan," July 25, 2007. It says that GNEP will "Develop, demonstrate, and deploy advanced technologies for recycling spent nuclear fuel that do not separate plutonium, with the goal over time of ceasing separation of plutonium, reducing or eliminating excess stocks of civilian plutonium, and drawing down existing stocks of civilian spent fuel."[GNEP-TECH-TR-PP-2007-00020] But, there is no definition of "separate".

2. "Process and Evaluation Criteria for Initial Screening of Fuel Cycle Options", October 25, 2010.[FCRD-SYSE-2011-000003, Rev 0] This document has Go/No-Go criteria in its Table 1. Table 1 includes this go/no-go criterion: "The system must not require storage of separated strategic SNM (e.g. HEU, U-233, or Pu)." The text above that table says "An additional revision was made based on discussion with Assistant Secretary for Nuclear Energy," which appears to have been taken as an endorsement of the criteria by DOE-NE-1. Again, no definition of "separate".

There is an internal FCT document in March 2011 that does include a footnote defining "separated".

"Separated $\mathrm{Pu}$ is defined here as $\mathrm{Pu}$ material in pure form. Material comingled with fission products, as well as constituents other than fission products, was not considered "separated" for purposes of evaluating this "separated strategic SNM" go/no-go criterion."

This March 2011 clarification footnote is consistent with the first interpretation - "separated plutonium" refers to only chemically pure plutonium. Thus, the March 2011 definition of "separation" allows LEU but also allows virtually all recycle options. With this clarification of "separation" (not known to have been approved by DOE-NE-1 as the October 2010 document apparently was), the only fuel cycles prohibited would seem to be HEU and use of Th/U233 options that involve extremely high-purity U233 stream resulting from separation of Pa233 from molten salt, which then decays to U233.

However, again, there is no known formal document prohibiting the second interpretation - "separated plutonium" is an issue even if plutonium remains mixed with uranium or other TRU. By extension, U233 would also be prohibited if mixed with other materials. As noted in sections 2.1.3, 2.1.4, and 2.1.5, under current NRC regulations, any sizable (more than $2 \mathrm{~kg}$ ) amount of U233 or Pu would appear to be SNM. Then, the second type of interpretation of "separated" would mean that virtually any separation of used fuel would be prohibited - with or without minor actinides, with or without chemical impurities.

\subsubsection{What is the "spent fuel standard" and does it have legal or regulatory force?}

The concepts of "spent fuel standard" and "self-protecting" have not been found in regulations nor laws. They do not have official definitions but they have had influence. 
The earliest mention found of the "spent fuel standard" and indeed of the underlying concept is 1993 . The issue in question was not disposition of spent fuel. It was how to protect against excess weaponsgrade plutonium. The dissolution of the USSR in 1990-1991 led to weapon inventory reduction, which led to the issue of excess weapon-grade plutonium. (Excess weapons-grade uranium is being resolved by downblending to make enriched uranium fuel.)

A concise statement of the spent fuel standard (without actually using that phrase) appears in the footnote to the 1995 OTA as it points to recommendations in the 1993-1994 time frame [OTA-O-572 and NAS1994) that

"urges that separated plutonium from weapons rapidly be put into a form where it would take at least as much effort to recover the plutonium as it would to reprocess plutonium from the much larger stocks of spent fuel already existing worldwide. The report also concludes that once weapon plutonium has been converted to such a form - for example by mixing it with radioactive waste to create "artificial spent fuel," or by converting it to mixed-oxide fuel and partially burning it in a lightwater reactor - there is little point to proceeding to eliminate it entirely before addressing those stocks of spent fuel as well."

Although developed for disposition of excess weapon-grade plutonium, from the start, the concept has been applied to plutonium-based fuel in recycling fuel cycles.

The 1993 report OTA-BP-ISC-115 refers to the IFR concept as producing "plutonium-containing fuel that is considerably more radioactive than that resulting from the traditional PUREX process, thus being less attractive for diversion to a weapon program." It does not say unattractive.

The 1994 report OTA-BP-ENV-126 uses Argonne's "self-protecting" terminology and seems to avoid saying whether ALMR/IFR pyroprocessing would or would not violate the Clinton 1993 policy as the report refers to "many are concerned".

"Many are concerned that a U.S. emphasis on ALMR/IFR development, with its inherent reliance on nuclear fuel reprocessing, could undermine this policy and stimulate other nations to undertake plutonium reprocessing programs. In his September 1993 statement, President Clinton said that although the United States will not interfere with reprocessing in Japan or Europe, "the United States does not encourage the civil use of plutonium and, accordingly, does not itself engage in plutonium reprocessing for either nuclear power or nuclear explosive purposes". If the United States breaks this long-standing norm by proceeding with the development of plutonium reprocessing technologies, other nations might be encouraged to consider LWR fuel without necessarily limiting the types of technologies used."

In some documents, the quantification of "spent fuel standard" occurs (at least in part) via the "selfprotecting" criterion.

Starting with Rev 1 of IAEA INFCIRC/225, in the context of physical protection of nuclear materials, the IAEA has defined the threshold between irradiated and unirradiated material as an exposure level of 100 $\mathrm{rad} /$ hour at 1 meter distance. This is commonly referred to the "self-protection" threshold. Their table on categorization of nuclear material defines unirradiated material as "Material not irradiated in a reactor or material irradiated in a reactor but with a radiation level equal to or less than $1 \mathrm{~Gy} / \mathrm{hr}(100 \mathrm{rad} / \mathrm{hr})$ at one meter unshielded." The analogous U.S. NRC categorizations appear in 10CFR74 and are identical except that the U.S. version is not in the form of a table and it lacks such a threshold.

Although the U.S. has no rule or regulation containing the above IAEA threshold, an unofficial selfprotection threshold of $100 \mathrm{rem} / \mathrm{hr}$ was developed during the (U.S.) National Academy of Science's plutonium disposition study.[NAS2000] Note that this study was not in the context of used commercial 
fuel, but rather disposition of excess plutonium, with fabrication into MOX followed by irradiation as one of the alternatives analyzed. Yet, one does find $100 \mathrm{rem} / \mathrm{hr}$ in the literature as a "self protecting" criterion for used commercial fuel.

Analysis - The Bathke et al figures of merit [Bathke2009, Bathke 2010] are constructed as if a new threshold value was $500 \mathrm{rad} / \mathrm{hour}$, versus the old "self-protecting" value of $100 \mathrm{rem} / \mathrm{hour}$. The change from rem to rad is significant. The old formulation $(100 \mathrm{rem} / \mathrm{hr})$ was based on the idea of people avoiding cancer risk. The unit of "rem" (or $\mathrm{Sv}=100 \mathrm{rem}$ ) is meant to measure the risk of long-term or "chronic" health effects such as cancer or genetic damage. The new formulation in the figures of merit (500 rad/hr) appears to relate to personnel impairment. The unit of " $\mathrm{rad"} \mathrm{(or} \mathrm{Gy}=100 \mathrm{rad}$ ) measures the risk of short-term or "acute" health effects such as the LD50-60 (the dose causing 50\% of an exposed population to die within 60 days).

This distinction between chronic and acute health effects and methods of calculating dose is not new. For example, it was used in dose assessments for the Reactor Safety Study (WASH-1400) in 1974. At that time, the LD50-60 for bone marrow exposure was $450 \mathrm{rad}$ (4.5 Gy).

The numerical values of "rem" and "rad" for external exposure differ only when the relative biological effectiveness or quality factor is other than one, e.g., for neutrons. The numerical values of "rem" and "rad" for internal exposure (inhalation and ingestion) also differ because of the time period for which isotopes are assumed to be irradiating the body. "Rem" is calculated via the 50 -year effective dose equivalent (EDE), which is a weighted sum of the cancer risk over the entire body. "Rad" is calculated for specific body organs with a short-time period, e.g., 7 day, appropriate for that organ and the health effect associated with that organ. For more details and examples, see en.wikipedia.org/wiki/ Acute_radiation_syndrome. That site states (with a citation) that the Central Nervous System function response is ...

\begin{tabular}{|c|c|c|c|c|}
\hline $1-2 \mathrm{~Gy}$ & $2-6 \mathrm{~Gy}$ & $6-8 \mathrm{~Gy}$ & $8-30 \mathrm{~Gy}$ & $>30 \mathrm{~Gy}$ \\
\hline $100-200 \mathrm{rad}$ & $200-600 \mathrm{rad}$ & $600-800 \mathrm{rad}$ & $800-3000 \mathrm{rad}$ & $>3000 \mathrm{rad}$ \\
\hline $\begin{array}{c}\text { No } \\
\text { impairment }\end{array}$ & $\begin{array}{c}\text { Cognitive impairment } \\
\text { [for] 6-20 h }\end{array}$ & $\begin{array}{c}\text { Cognitive } \\
\text { impairment }>24 \mathrm{~h}\end{array}$ & $\begin{array}{c}\text { Rapid } \\
\text { incapacitation }\end{array}$ & $\begin{array}{c}\text { Seizures, Tremor, } \\
\text { Ataxia, Lethargy }\end{array}$ \\
\hline
\end{tabular}

An incapacitation threshold of $500 \mathrm{rad} / \mathrm{hr}$ is based on the ORNL review of exposure data.[Coates2005] To date the United States government has not issued an official radiation dose threshold above which the proliferation risk is so low as to be acceptable. (Statement confirmed by B. Bathke.)

\subsubsection{When did the federal government begin offering to take used fuel from utilities?}

In October 1977, "the DOE announced that the Federal Government would begin accepting and taking title from utilities to spent nuclear fuel that previously was to be reprocessed"[GAO-EMD-78-97, GA01978 Barnwell testimony], thereby undercutting the rationale and market for the reprocessing plant under construction in Barnwell South Carolina. This has been codified into law as follows. NWPA section 302.a.5 states, "(A) following commencement of operation of a repository, the Secretary shall take title to the high-level radioactive waste or spent nuclear fuel involved as expeditiously as practicable upon the request of the generator or owner of such waste or spent fuel; and (B) in return for the payment of fees established by this section, the Secretary, beginning not later than January 31, 1998, will dispose of the high-level radioactive waste or spent nuclear fuel involved as provided in this subtitle."

\subsubsection{Disposal of spent fuel versus HLW.}

Prior to 1977, spent fuel was to be recycled as discussed in section 2.1.1. Although Carter (and Clinton) changed presidential policy, spent fuel and HLW remained legally distinct. 
In 1977, the Ford/MITRE study ${ }^{\mathrm{p}}$ observed

"In the past, the waste disposal problem has generally been approached on the assumption that spent fuel would be reprocessed to recover plutonium for recycle. Decisions on disposal were continually deferred pending successful introduction of plutonium recycle. As a consequence, it is widely believed that reprocessing is a necessary stage in the waste disposal process. However, if plutonium it not recycled in light-water reactors or used eventually in breeders, there is no reason to reprocess spent reactor fuel. In fact, reprocessing potentially increases short-term risks associated with management of nuclear wastes and does not significantly reduce long-term risks after disposal."[Ford/MITRE1977]

Also in 1977 ,

"spent fuel has not yet been defined by the Nuclear Regulatory Commission as high level waste and may not be because of its potential value as a source of fuel if reprocessed. This report will consider spent fuel as a "potential" high level waste. Commercial reactor spent fuel is accumulating at nuclear powerplants because there are no commercial reprocessors now operating in the United States. Resumption of reprocessing does not seem probable in the near future since President Carter has indefinitely deferred commercial reprocessing of spent fuel. If it is finally decided that there will be no further commercial reprocessing, spent fuel elements from existing and future civilian power reactors probably will have to be managed as high level radioactive waste. Meanwhile, nuclear powerplants have had to store their spent fuel in storage pools at the reactor sites. As a result, a backlog of spent fuel is accumulating at the powerplants."[GAO-EMD-77-41]

Similarly, the Nuclear Waste Policy Act of 1982, as amended, states that HLW is

(A) the highly radioactive material resulting from the reprocessing of spent nuclear fuel, including liquid waste produced directly in reprocessing and any solid material derived from such liquid waste that contains fission products in sufficient concentrations; and

(B) other highly radioactive material that the Commission, consistent with existing law, determines by rule requires permanent isolation.

The NWPA has separate definitions for low-level radioactive waste and for "spent nuclear fuel", the latter defined as

"fuel that has been withdrawn from a nuclear reactor following irradiation, the constituent elements of which have not been separated by reprocessing."

(In reviewing a draft of this report, reviewer Jim Buelt notes that the NWPA is also the source of the 70,000 metric tonnes of spent fuel capacity limit on the first geologic repository. This legal limit is absolute until and unless there is a second repository in operation. There is no legal clause for exceeding 70,000 metric tonnes (or its equivalent) if burnup varies or only the residual waste after separation and recycling is disposed. Indeed, the assessment of how much DOE waste can be disposed within its 7,000 allocation (part of the 70,000) includes back calculation of the equivalent initial heavy metal.)

Today, the situation has changed.

Using its explicit authority in NWPA noted above, the NRC in 10CFR60.2 now defines HLW as follows:

High-level radioactive waste or HLW means: (1) Irradiated reactor fuel, (2) liquid wastes resulting from the operation of the first cycle solvent extraction system, or equivalent, and the concentrated

p. "Ford" here means the "Ford Foundation," not President Ford. 
wastes from subsequent extraction cycles, or equivalent, in a facility for reprocessing irradiated reactor fuel, and (3) solids into which such liquid wastes have been converted.

Similarly, the NRC in 10CFR63.2 now defines HLW as follows:

(1) The highly radioactive material resulting from the reprocessing of spent nuclear fuel, including liquid waste produced directly in reprocessing and any solid material derived from such liquid waste that contains fission products in sufficient concentrations;

(2) Irradiated reactor fuel; and

(3) Other highly radioactive material that the Commission, consistent with existing law, determines by rule requires permanent isolation.

\subsubsection{Candidate geologic repositories and "east of the Mississippi"}

This complicated subsection is summarized as follows:

Before the mid-1970s, salt was the only medium studied in sufficient depth that specific candidates were identified. Indeed, the National Academy of Sciences recommended salt in 1957.[NAS1957] Retrievability of the waste (assumed to be remnants after recovering actinides) was not an issue, but intermediate half-life isotopes were: "Separation of the $\mathrm{Cs}$ and $\mathrm{Sr}$ isotopes from the waste and their storage in small packages or surface tanks would of course greatly simplify the general problem of waste disposal."'[NAS1957]

After 1977 with the policy changed toward direct disposal, the emphasis on retrievability grew. The Nuclear Waste Policy Act [NWPA] makes retrievability a requirement during the period of repository operations.

At varying times, basalt, salt dome, bedded salt, tuff, granite, clay, and borehole have been studied for a U.S. geologic repository, but at no specific time (including now) have all such candidate environments been under study, which would allow them to be considered against the same criteria in the same context.

The author finds no formal requirement that a second geologic repository be sited east of the Mississippi. This concept appears related to the facts that no granite site was included in the nine formal candidates for the first repository and the first set of proposed sites for the second repository were all granite. Two of the nine first repository candidates were east of the Mississippi.

Now, details.

In 1972 and 1976, respectively, the bedded salt sites in Lyons Kansas and Michigan were found unsuitable for a combination of technical and political reasons. [GAO-EMD-77-41, Lomenick1996, Carter1987]

Environments other than salt first entered the U.S. program in March 1972.[Lomenick1996]

"This expansion was partly caused by the belief that the siting of repositories in several different sections of the country would be viewed by the states as a fair sharing of the "burden" of hosting a repository and thus would be accepted."[Lomenick1996]

"Although the greatest effort in the early 1970 s to locate a repository was focused on government owned land in southeastern New Mexico, regional investigations were also begun in the salt deposits of the Paradox, Appalachian, and Michigan basins, and on the Gulf Coast salt domes. Investigations of several rock types (argillite, granite, and volcanic tuff) at the Nevada Test Sites and of basalt at the 
Hanford Site were under way as were preliminary siting studies of bedded salt in the Pala Duro Basin of west Texas. Thus, by the mid-1970s, regions were under study that contains all of the sites that later became nominated as candidates for the first repository."[Lomenick1996]

With the demise of the first two salt repository site projects and of reprocessing, in 1977 ERDA started a two-pronged approach. One prong was to develop six repositories. "The six repositories were arrived at mainly to spread nuclear waste regionally throughout the Nation and minimize any setback to the program should a potential site(s) prove unacceptable. Storage and/or disposal of spent fuel in geological formations requires more acreage than is needed for storage and/or disposal of high level waste."[GAOEMD-77-41] The second prong was interim storage in a "Surface Unreprocessed Fuel Facility (SURFF)" to "provide safe and economical storage of spent fuel."[GAO-EMD-77-41]

In 1980, DOE completed an Environmental Impact Statement for management of commercially generated radioactive waste.[DOE/EIS-0046F] It did not address specific sites per se. It stated "salt, granite, shale and basalt are considered as examples of repository host rock. These rock types represent a range of characteristics of candidate earth material representative of geologic formations that might be considered but other rock types such as tuff may also be suitable candidates." It also identified alternative concepts: "very deep hole, rock melt, island-based, subseabed, ice sheet, well injection, and space disposal." See extracts from this reference in Chapter 4 for more information on how these alternatives were defined.

By 1981 , the six repository program had evolved to studying five geologic environments: basalt, salt dome, bedded salt, tuff, and granite. The plan was to select five candidates with five geologic environments by June 1985, with an overall selection thereafter.[GAO EMD-81-78] "The initial two repositories would be developed in salt and were intended to begin pilot operations as soon as 1985 . The remaining four repositories would be built in other rock types, such as shales or crystalline rocks and would be operational by the mid-1990s."[Lomenick1996]

By the Nuclear Waste Policy Act (NWPA) of 1982, the DOE was to nominate five candidate sites, with no requirement of one with each type of geologic environment, e.g., all five could have had the same environment. In February 1983, DOE identified "nine potentially acceptable sites for the first repository in the locations listed in Table 2. The environments were bedded salt $(n=4)$, salt dome $(n=3)$, basalt $(\mathrm{n}=1)$, tuff $(\mathrm{n}=1)$. "With the exception of Cypress Creek Dome, which underlies national forest lands, the salt sites are on private lands. The two nonsalt sites are on lands under the control of the federal government."[Lomenick1996]

Two of the nine sites were east of the Mississippi River (the two in Mississippi); none were in the northeast of the U.S.; none were in granite. Granite was the only environment that had been studied in 1981 that was not included in the 1983 list of nine sites. The author of this report is not certain why granite was not included in the 1983 sites; however, in reading Lomenick1996, it appears that shale/clay/argillite and granite/crystalline rock were simply less advanced as concepts than salt, basalt, and tuff. And, between those two alternatives, granite was considered the more attractive. See for example pages 40-41 of Lomenick1996. By 1980 it appears that salt was the leading candidate for the first repository as evidenced by salt sites being 7 of 9 candidates in 1983 (the other two were basalt and tuff) and granite/crystalline rock was the leading candidate for the second repository (per Lomenick). 
Table 2 of report. Evolution of Geologic Repository Candidate Geologic Environments.

\begin{tabular}{|c|c|c|c|c|c|c|c|}
\hline \multirow{2}{*}{1977} & \multirow{2}{*}{\multicolumn{2}{|c|}{\begin{tabular}{|l|l|}
1980 & 1981 \\
\end{tabular}}} & \multirow[b]{2}{*}{1983} & \multirow{2}{*}{\multicolumn{2}{|c|}{1984}} & \multirow[b]{2}{*}{1986} & \multirow[b]{2}{*}{2011} \\
\hline & & & & & & & \\
\hline $\begin{array}{l}\text { First plan } \\
\text { after Carter } \\
\text { policy, } 6 \\
\text { actual } \\
\text { repositories }\end{array}$ & $\begin{array}{c}\text { Final } \\
\text { Environ- } \\
\text { mental } \\
\text { Impact } \\
\text { Statement } \\
\text { for mgt of } \\
\text { radioactive } \\
\text { wastes }\end{array}$ & $\begin{array}{c}\text { Study } 5 \\
\text { geologic } \\
\text { environ- } \\
\text { ments to } \\
\text { identify } 5 \\
\text { candidates }\end{array}$ & $\begin{array}{l}9 \text { sites } \\
\text { identified for } \\
\text { first } \\
\text { repository }\end{array}$ & $\begin{array}{l}5 \text { sites } \\
\text { nominated } \\
\text { for site } \\
\text { character- } \\
\text { ization for } \\
\text { first } \\
\text { geologic } \\
\text { repository }\end{array}$ & $\begin{array}{l}3 \text { sites } \\
\text { recommended } \\
\text { for site } \\
\text { characteriza- } \\
\text { tion for first } \\
\text { geologic } \\
\text { repository }\end{array}$ & $\begin{array}{l}\text { Draft Area } \\
\text { Recommenda- } \\
\text { tion Report as } \\
\text { part of process } \\
\text { for second } \\
\text { geologic } \\
\text { repository }\end{array}$ & $\begin{array}{c}\text { FCR\&D } \\
\text { Used Fuel } \\
\text { Disposition } \\
\text { campaign } \\
\text { analysis of } \\
\text { generic } \\
\text { environments }\end{array}$ \\
\hline $\begin{array}{l}\text { GAO-EMD- } \\
77-41\end{array}$ & $\begin{array}{c}\text { DOE/EIS- } \\
0046 \mathrm{~F}\end{array}$ & $\begin{array}{c}\text { GAO- } \\
\text { EMD-81- } \\
78 \\
\end{array}$ & $\begin{array}{l}\text { DOE/RW- } \\
0074\end{array}$ & $\begin{array}{l}\text { DOE/RW- } \\
0074\end{array}$ & DOE/S-0048 & $\begin{array}{c}\mathrm{DOE} / \mathrm{CH}- \\
15(0)\end{array}$ & Clayton2011 \\
\hline \multirow{12}{*}{$\begin{array}{l}\text { "The six } \\
\text { repositories } \\
\text { were arrived } \\
\text { at mainly to } \\
\text { spread } \\
\text { nuclear } \\
\text { waste } \\
\text { regionally } \\
\text { throughout } \\
\text { the Nation } \\
\text { and } \\
\text { minimize } \\
\text { any setback } \\
\text { to the } \\
\text { program } \\
\text { should a } \\
\text { potential } \\
\text { site(s) prove } \\
\text { unacceptable } \\
. "\end{array}$} & Basalt & Basalt & Hanford, WA & & & $\begin{array}{l}\text { "Basalt Waste } \\
\text { Isolation } \\
\text { Project" }\end{array}$ & $\begin{array}{l}\text { Not } \\
\text { considered }\end{array}$ \\
\hline & \multirow{7}{*}{ Salt } & \multirow{3}{*}{ Salt dome } & $\begin{array}{l}\text { Vacherie } \\
\text { dome, LA }\end{array}$ & \multicolumn{2}{|l|}{ dropped } & & \multirow{7}{*}{ Salt } \\
\hline & & & $\begin{array}{l}\text { Cypress } \\
\text { Creek dome, } \\
\text { MS }\end{array}$ & dropped & & & \\
\hline & & & Richton Dome & $\mathrm{MS}$ & dropped & & \\
\hline & & \multirow{4}{*}{$\begin{array}{l}\text { Bedded } \\
\text { salt }\end{array}$} & $\begin{array}{l}\text { Swisher } \\
\text { County, TX }\end{array}$ & dropped & & \multirow{4}{*}{$\begin{array}{l}\text { "Salt } \\
\text { Repository } \\
\text { Project" }\end{array}$} & \\
\hline & & & $\begin{array}{l}\text { Lavender } \\
\text { Canyon, UT }\end{array}$ & dropped & & & \\
\hline & & & & & dropped & & \\
\hline & & & \multicolumn{3}{|c|}{ Deaf Smith County, TX } & & \\
\hline & $\begin{array}{l}\text { Tuff was an } \\
\text { alternate } \\
\text { concept. }\end{array}$ & Tuff & \multicolumn{3}{|c|}{ Yucca Mountain, NV } & $\begin{array}{l}\text { "Nevada } \\
\text { Nuclear Waste } \\
\text { Storage } \\
\text { Investigations" }\end{array}$ & $\begin{array}{l}\text { Not } \\
\text { considered; } \\
\text { adequate } \\
\text { analysis done } \\
\text { for Yucca to } \\
\text { understand } \\
\text { this case }\end{array}$ \\
\hline & $\begin{array}{l}\text { Granite } \\
\text { (crystalline } \\
\text { rock) }\end{array}$ & Granite & \multicolumn{3}{|c|}{ Not one of the candidates } & $\begin{array}{l}12 \text { candidate } \\
\text { areas in } 7 \\
\text { states } \\
\text { identified by } \\
\text { "Crystalline } \\
\text { Repository } \\
\text { Project" }\end{array}$ & Granite \\
\hline & $\begin{array}{l}\text { Shale/clay/ } \\
\text { argillite }\end{array}$ & \multicolumn{5}{|c|}{ Not one of the candidates } & Clay \\
\hline & $\begin{array}{l}\text { Deep hole } \\
\text { was an } \\
\text { alternate } \\
\text { concept. }\end{array}$ & \multicolumn{5}{|c|}{ Not one of the candidates } & Borehole \\
\hline
\end{tabular}

The geologic environments mentioned by Lomenick1996 but not included in Table 2 are limestone, chalk, and talc. None of these became site candidates.

Meanwhile, the concept of retrievability grew and was then mandated in the NWPA in 1982. "President Carter's ban on reprocessing placed a greater emphasis than before on retrievability."[Lomenick1996] 
In 1984, DOE nominated five sites, which covered four of the rock environments (not granite) - bedded salt (2), salt dome (1), basalt (1), tuff (1). One of the five sites was east of the Mississippi River. In 1986, three of the five nominated sites were recommended for site characterization, with three different rock environments, none east of the Mississippi.[DOE/S-0048] See Table 2.

Amendments to the NWPA in 1987 halted the previous first repository process, stopped the second repository, and identified only Yucca Mountain, Nevada, for site characterization for the first repository. The 1987 amendments specifically required phaseout of granite repository research.

Indeed, back in 1986, for a second repository, DOE had issued a draft "Area Recommendation Report" that recommended twelve areas with "crystalline rock" (a.k.a. granite).[DOE/CH-15(0)] "More than 60,000 comments on the ARR were received as of June 30,1988, which was the congressionally mandated (NWPA) phase-out of the Crystalline Repository Program."[Lomenick1996] This 1986 activity had the effect of restarting the effort in all five geologic environments, which then ended in 1988 because of the 1987 NWPA amendment requiring phaseout. All of the granite candidate areas were in the east of the U.S. (As one area was in Minnesota, the phrase "east of the Mississippi" is not quite accurate.) DOE noted that

"OCRWM is currently considering bedded salt deposits, salt domes, basalt, tuff, and crystalline rock as host rocks for geologic repositories. These rock types are being analyzed at different locations within the conterminous United States under four coordinated projects: the Basalt Waste Isolation Project, the Salt Repository Project, the Nevada Nuclear Waste Storage Investigations, and the Crystalline Repository Project."[DOE/CH-15(0)]

DOE's stated intention, however, was not to limit the second repository to granite sites and hence to sites east of the Mississippi.

"DOE is considering two sources of sites for the second repository: crystalline rock formations, which are already the subject of a comprehensive screening program conducted by the Crystalline Repository Project, and sites which will have been characterized for the first repository but are not selected for the first repository site, and sites evaluated but not nominated for site characterization for the first repository."[DOE CH-15(0)]

However, a half-year later, DOE ended the second repository effort.

"At the same time [as the recommendation of three sites for the first repository site characterization], the Secretary announced that DOE would defer the process of screening and selecting a site for a second repository because projections of decreasing quantities of nuclear waste indicated that a second repository would not be needed as soon as had been anticipated."[GAO-RCED-92-73]

DOE would have recommended a single site for a second repository in March 1998.[DOE CH-15(0)]

The author of the present report found no requirement that the second repository would be east of the Mississippi but it is true that (a) there were no first repository candidates recommended east of the Mississippi, (b) although granite was one of the five environments studied in this time period, it was not included in the five sites nominated in 1984, (c) all granite sites are east of the Mississippi (taking liberty with Minnesota), and (d) the first public candidates announced for the second repository were all granite sites, all east of the Mississippi (again taking liberty with Minnesota).

The author has dug enough to see that geographical diversity (perhaps even specifically "east of the Mississippi") was discussed in the Senate during 1981-1982. A key person in the Senate's deliberation record is Senator Slade Gorton $(R-W A)$. 
Gorton introduced the 70,000 tonne-iHM cap on the first repository capacity in 1982. See Senate amendment S.UP.AMDT.878 to S.1662 of 4/29/1982 by Slade Gorton

"Providing that the Commission decision approving the first application shall prohibit the emplacement in the first repository of a quantity of spent fuel containing in excess of 70,000 metric tons of heavy metal or a quantity of solidified high-level radioactive waste resulting from the reprocessing of such a quantity of spent fuel until such time as a second repository is in operation".

Senator Gorton also made the motion that inserted a similar clause regarding a monitored retrievable storage facility. See Senate amendment S.UP.AMDT.879 to S.1662 of 4/29/1982 by Slade Gorton

"Providing that in the event a monitored retrievable storage facility, approved pursuant to Title V, shall be located, or is planned to be located, within 50 miles of the first repository, then the Commission decision approving the first such application shall prohibit the emplacement of a quantity of spent fuel containing in excess of 70,000 metric tons of heavy metal or a quantity of solidified high-level radioactive waste resulting from the reprocessing of spent fuel in both the repository and monitored retrievable storage facility until such time as a second repository is in operation."

Recall that in 1982 that Washington was one of states most considered for the first repository. Senator Henry (Scoop) Jackson (D-WA) co-sponsored both amendments noted above.

Gorton stated his rationale in Congressional debate on December 20, 1982,

"In the case of the State of Washington, it is my opinion that it should be asked to do no more than provide nuclear disposal capacity adequate to dispose of those wastes which are generated within a range of distance in which the transportation risks can be minimized. Other States in other regions of the country should be responsible to provide disposal capacity for nuclear waste generated within similar ranges of those disposal facilities. We should not be planning to move high-level nuclear waste across the continent if we can avoid it. We should not be looking to a State on one side of the continent to provide disposal capacity for waste generated on the other. " (Congressional Record Dec. 20,1982 , p. S15667.) as cited in OTA-O-171.

The above cited OTA report OTA-O-171 in 1985 indicates that the NWPA of 1982 (not yet amended in 1987) "requires the development of two geologic repositories.(*) It also specifies that transportation impacts be taken into account in siting the second repository, a stipulation that appears to be intended to encourage location of the second repository closer to the sources of waste generation than the sites now under investigation for the first repository."

(*) In the above OTA quote, a footnote in the original OTA document states, "IRG, for example, recommended siting repositories on a regional basis, as far as the technical considerations would permit, IRG, pp. 51-52." The IRG was established by President Carter; its draft report cited by OTA was “Interagency Review Group on Nuclear Waste Management (IRG), Subgroup Report on Alternative Technology Strategies for the Isolation of Nuclear Waste, TID-28818 (draft), (Washington, D. C.: October 1978)."

This regional repository concept returns the story back to the 1977 approach of six regional repositories noted in GAO-EMD-77-41.

Returning to the subject of retrievability, it might be interesting to note:

"The waste types to be considered in the design process for receipt at the second repository are spent fuel and solidified defense high-level waste, but the design will not preclude disposal of solidified reprocessed commercial high-level and transuranic wastes... The repository will be designed so that any or all of the emplaced waste can be retrieved on a reasonable schedule starting at any time up to 
50 years after emplacement operations are initiated, unless a different time period is approved or specified by the U.S. Nuclear Regulatory Commission."[DOE CH-15(0)]

The WIPP project in New Mexico is in bedded salt, and is open for non-heat-producing non-commercial waste, DOE did not intend it for commercial waste although GAO recommended that option in 1977.[GAO-EMD-77-41]

In 1996, ORNL published a detailed technical report [Lomenick1996] on the selection of Yucca Mountain. ORNL did much of the early repository work. A reviewer of this current document, Charles Forsberg, noted that ORNL declined to continue because its contractor, Union Carbide, did not want the political fallout of HLW management.

In 2010, Sandia published a report [SAND2010-6335] on UFD Technical Bases and Lessons Learned. It did not address site selection history prior to WIPP and Yucca Mountain.

\subsubsection{When and why were fissile breeding ratio and transuranic conversion ratio defined?}

Even though both "fissile breeding ratio" and "transuranic conversion ratio" are sometimes considered as indicators for relative waste management hazards, neither was defined with that purpose.

The first mention found of the fissile breeding ratio (creation of fissile material divided by destruction of fissile material) was by Fermi et al at a meeting on April 26, 1944, documented by a memo reproduced by Koch2008.

The first mention found of the transuranic conversion ratio (creation of TRU divided by destruction of TRU) was Hannum1997. It is inappropriate for, and never intended for, $T h / U 233$ fuel cycles. It was claimed to be a more appropriate measure of fuel supply for fast reactors than the fissile breeding ratio.

"For a system fueled with transuranics and U238, the "conversion ratio" (CR) is defined as the ratio of the gross production rate of plutonium and higher transuranic material from U238 to the destruction rate of this material. A conversion ratio of 1.0 implies equality of production and destruction rates - in other words, self-sufficient operation requiring only periodic makeup additions of uranium. In the fast reactor context, the total quantity of transuranic material is used in the definition of conversion ratio because all transuranics are fissionable in a fast spectrum, not just the fissile isotopes as in thermal reactors."[Hannum1997]

\subsection{Integrated Timeline of Events and Documents}

The author has assembled the following table of events and documents to aid in seeing how the four topics of breeder reactors, reprocessing, plutonium separation, and uranium enrichment have evolved. Presidential actions in the timeline are explicit, plus key bills signed into law. Congressional actions in the time line are often less explicit, but they also include key bills passed and delivered to the president.

Table 3 of report. Timeline of Events and Documents Assembled for this Report.

\begin{tabular}{|c|c|c|c|c|}
\hline $\begin{array}{l}\text { Event or } \\
\text { document }\end{array}$ & Breeder reactors & Reprocessing & Separation of $\mathrm{Pu}$ & $\begin{array}{l}\text { Uranium } \\
\text { enrichment }\end{array}$ \\
\hline \multicolumn{5}{|c|}{ September 27, 1905, Einstein publishes $E=\mathrm{mc}^{2}$ [Einstein 1905$]$} \\
\hline \multicolumn{5}{|c|}{ 1938, Hahn, Strassmann, Meitner, and Frisch discover nuclear fission } \\
\hline \multicolumn{5}{|c|}{ August 2,1939 , Einstein writes to Roosevelt about the possibility of an atomic weapon [Einstein1939] } \\
\hline \multicolumn{5}{|c|}{ December 2,1942, first fission reactor went critical, CP-1 } \\
\hline \multicolumn{5}{|c|}{$\begin{array}{l}\text { April 26, 1944, Fermi, Szilard, Wigner, Weinberg meeting outlining possibility of electricity from } \\
\text { controlled fission via fast breeder reactors; definition of breeding ratio [NuclearNews } 2004 \text {, Koch2008] }\end{array}$} \\
\hline
\end{tabular}




\begin{tabular}{|c|c|c|}
\hline \multicolumn{3}{|c|}{ August 6, 1945, Hiroshima [Truman 1945] } \\
\hline \multicolumn{3}{|c|}{ August 9,1945, Nagasaki } \\
\hline \multicolumn{3}{|c|}{$\begin{array}{l}\text { August 12,1945, Declassification of existence of both uranium and plutonium pathways, mentions } \\
\text { Einstein's letter to Roosevelt [Smyth1945] }\end{array}$} \\
\hline $\begin{array}{l}\text { Atomic Energy } \\
\text { Act of } 1946 \\
\text { August } 1,1946 \\
\text { [AEA1946] }\end{array}$ & \multicolumn{2}{|c|}{$\begin{array}{l}\text { - "source material means uranium, thorium, or any other material which is determined by the } \\
\text { Commission, with the approval of the President, to be peculiarly essential to the production of } \\
\text { fissionable materials"[AEA1946, Sec 5.(b)(1)] } \\
\text { "fissionable material means plutonium, uranium enriched in the isotope } 235 \text {, any other material } \\
\text { which the Commission determines to be capable of releasing substantial quantities of energy } \\
\text { through nuclear chain reaction of the material, or any material artificially enriched by any of the } \\
\text { foregoing; but does not include source materials" [AEA1946, Sec 5.(a)(1)] }\end{array}$} \\
\hline $\begin{array}{l}\text { EBR-I, December } \\
20,1951\end{array}$ & \multicolumn{2}{|c|}{ First nuclear electricity is from a breeder reactor } \\
\hline \multicolumn{3}{|c|}{ 1953, Hiroshima identified as a uranium bomb and Nagasaki as a plutonium bomb [RDD-8] } \\
\hline $\begin{array}{l}\text { D. D. Eisenhower } \\
\text { Atoms for Peace, } \\
\text { December } 8,1953\end{array}$ & & $\begin{array}{l}\text { "nuclear powers contribute portions of their } \\
\text { stockpiles of normal uranium and fissionable } \\
\text { materials to an international atomic energy } \\
\text { agency, which would then allocate these } \\
\text { materials for peaceful purposes."[AEC1983] }\end{array}$ \\
\hline $\begin{array}{l}\text { Atomic Energy } \\
\text { Act of } 1954, \\
\text { August } 30,1954 \\
\text { [AEA1954] }\end{array}$ & \multicolumn{2}{|c|}{$\begin{array}{l}\text { "The term "source material" means (1) uranium, thorium, or any other material which is determined } \\
\text { by the Commission pursuant to the provisions of section } 61 \text { to be source material; or (2) ores } \\
\text { containing one or more of the foregoing materials, in such concentration as the Commission may by } \\
\text { regulation determine from time to time." [AEA1954] } \\
\text { "The term "special nuclear material" means (1) plutonium, uranium enriched in the isotope } 233 \text { or in } \\
\text { the isotope } 235 \text {, and any other material which the Commission, pursuant to the provisions of section } \\
51 \text {, determines to be special nuclear material, but does not include source material; or (2) any } \\
\text { material artificially enriched by any of the foregoing, but does not include source material." } \\
\text { [AEA1954] } \\
\text { Thus, relative to the Atomic Energy Act of 1946, [AEA1946] the term SNM replaces } \\
\text { "fissionable material" and U233 is added to the list of such materials. }\end{array}$} \\
\hline \multicolumn{3}{|c|}{ National Academy of Sciences recommends geologic disposal, April 1957 [NAS1957] } \\
\hline \multicolumn{3}{|c|}{ IAEA inaugurated, October 1,1957} \\
\hline \multicolumn{3}{|c|}{ EBR-II taken critical, September 30, 1960 [NuclearNews2004] } \\
\hline $\begin{array}{l}\text { Report to } \\
\text { President [AEC } \\
1962]\end{array}$ & \multicolumn{2}{|c|}{$\begin{array}{l}\text { "The program should include: (1) early construction of plants of the presently most competitive } \\
\text { reactor types; (2) development, construction and demonstration of advanced converters to improve } \\
\text { the economics and the use of nuclear fuels; (3) intensive development and, later, demonstration of } \\
\text { breeder reactors to fill the long-range needs of utilizing fertile as well as fissile fuels." [AEC1962] }\end{array}$} \\
\hline \multicolumn{3}{|c|}{ The fact that Nagasaki was Pu239 alone was declassified in 1965.[RDD-8] } \\
\hline \multicolumn{3}{|c|}{$\begin{array}{l}\text { "In } 1965 \text { ORNL started storing spent fuel elements in an abandoned salt mine near Lyons, Kansas, to } \\
\text { examine the effects of radiation and heat on salt."[GAO-EMD-77-41] }\end{array}$} \\
\hline $\begin{array}{l}\text { AEC, report to } \\
\text { President, } 1967 \\
\text { (have not found } \\
\text { copy of this } \\
\text { report) }\end{array}$ & $\begin{array}{l}\text { LMFBR is highest } \\
\text { reactor development } \\
\text { priority [AEC1983] }\end{array}$ & \\
\hline \multicolumn{3}{|c|}{$\begin{array}{l}\text { 1967, government declassified "The fact that reactor grade plutonium can be used to make nuclear } \\
\text { weapons" and "that high irradiation level reactor-grade plutonium can be used to make nuclear } \\
\text { weapons." [RDD-8] }\end{array}$} \\
\hline \multicolumn{3}{|c|}{$\begin{array}{l}\text { "In June } 1970 \text { AEC announced that it would build a Federal waste repository at the Lyons mine if } \\
\text { further geologic studies confirmed the site's suitability." But potential for water entry led to } \\
\text { abandonment of the site two years later.[GAO-EMD-77-41] }\end{array}$} \\
\hline $\begin{array}{l}\text { R. M. Nixon, } \\
\text { statement, } \\
\text { June } 4,1971 \\
\text { [Nixon1971]- }\end{array}$ & $\begin{array}{l}\text { High priority to breed } \\
1980 \text { goal for complet } \\
\text { AEC1983] } \\
\text { "The breeder reactor } \\
\text { natural uranium fuel s }\end{array}$ & \\
\hline
\end{tabular}




\begin{tabular}{|c|c|c|c|c|}
\hline $\begin{array}{l}\text { first known } \\
\text { explicit } \\
\text { Presidential } \\
\text { policy for } \\
\text { breeders and } \\
\text { recycling. }\end{array}$ & \multicolumn{2}{|c|}{$\begin{array}{l}\text { centuries, with far less impact on the } \\
\text { environment than the power plants which are } \\
\text { operating today."[Nixon1971] }\end{array}$} & & \\
\hline $\begin{array}{l}\text { IAEA, structure of } \\
\text { safeguard } \\
\text { agreements, } \\
\text { INFCIRC/153, } \\
\text { June } 1972\end{array}$ & & & $\begin{array}{l}\text { Plutonium over } 80 \% \\
\text { Pu238 exempted from } \\
\text { safeguards }\end{array}$ & $\begin{array}{l}\text { Formula for } \\
\text { determining how } \\
\text { much uranium can be } \\
\text { exempted from } \\
\text { safeguard has } \\
\text { threshold at } 20 \% \\
\text { U235 }\end{array}$ \\
\hline \multicolumn{5}{|c|}{$\begin{array}{l}\text { In the early 1970s.... } \\
\text { The beginning of WIPP - "Selection of the Delaware Basin in southeastern New Mexico as a potential } \\
\text { disposal site for radioactive waste" [SAND99-2719J] } \\
\text { The beginning of Yucca Mountain - "Although the greatest effort in the early 1970s to locate a } \\
\text { repository was focused on government owned land in southeastern New Mexico, regional } \\
\text { investigations were also begun in the salt deposits of the Paradox, Appalachian, and Michigan basins, } \\
\text { and on the Gulf Coast salt domes. Investigations of several rock types (argillite, granite, and volcanic } \\
\text { tuff) at the Nevada Test Site and of basalt at the Hanford Site were under way as were preliminary } \\
\text { siting studies of bedded salt in the Palo Duro Basin of west Texas.[Lomenick1996] }\end{array}$} \\
\hline \multicolumn{5}{|c|}{ May 18,1974, India tests first nuclear "device", used plutonium } \\
\hline $\begin{array}{l}\text { IAEA, physical } \\
\text { protection, } \\
\text { INFCIRC/ } 225 \text {, } \\
1975\end{array}$ & & & & $\begin{array}{l}\text { U235 enrichment } \\
\text { criteria at } 10 \% \text { and } \\
20 \% \text { appear }\end{array}$ \\
\hline $\begin{array}{l}\text { G. R. Ford, } \\
\text { Statement on } \\
\text { Nuclear Policy, } \\
\text { October 28, } 1976 \\
\text { [Ford1976] }\end{array}$ & \multicolumn{3}{|c|}{$\begin{array}{l}\text { "the reprocessing and recycling of plutonium should not proceed unless } \\
\text { there is sound reason to conclude that the world community can } \\
\text { effectively overcome the associated risks of proliferation ... that the United } \\
\text { States should no longer regard reprocessing of used nuclear fuel to } \\
\text { produce plutonium as a necessary and inevitable step in the nuclear fuel } \\
\text { cycle, and that we should pursue reprocessing and recycling in the future } \\
\text { only if they are found to be consistent with our international } \\
\text { objectives."[Ford1976] }\end{array}$} & \\
\hline $\begin{array}{l}\text { J. E. Carter, } \\
\text { PD/NSC-8, } \\
\text { March 24, } 1977 \\
\text { Declassified on } \\
\text { March 15, 1994. }\end{array}$ & $\begin{array}{l}\text { "Restructure the U.S. } \\
\text { breeder program so as } \\
\text { to emphasize alter- } \\
\text { native designs to the } \\
\text { plutonium breeder, } \\
\text { and to meet a later } \\
\text { date for possible } \\
\text { commercialization." } \\
\text { [PD/NSC-8] }\end{array}$ & $\begin{array}{l}\text { "Indefinitely defer the } \\
\text { commercial } \\
\text { reprocessing and } \\
\text { recycle of plutonium } \\
\text { in the U.S."[PD/NSC- } \\
8 \text { ] }\end{array}$ & \multicolumn{2}{|c|}{$\begin{array}{l}\text { "U.S. non-proliferation policy shall be directed } \\
\text { at preventing the development and use of } \\
\text { sensitive nuclear power technologies which } \\
\text { involve direct access to plutonium, highly } \\
\text { enriched uranium, or other weapons useable } \\
\text { material in non-nuclear weapons states, and at } \\
\text { minimizing the global accumulation of these } \\
\text { materials."[PD/NSC-8] }\end{array}$} \\
\hline $\begin{array}{l}\text { J. E. Carter, public } \\
\text { statement, } \\
\text { April 7, 1977 } \\
\text { [Carter 1977] }\end{array}$ & $\begin{array}{l}\text { Attempt to cancel } \\
\text { CRBR and defer } \\
\text { LMFBR commer- } \\
\text { cialization. }\end{array}$ & $\begin{array}{l}\text { Attempt to cancel } \\
\text { Barnwell, which was } \\
\text { eventually terminated } \\
\text { in } 1981 .\end{array}$ & & \\
\hline DOE, 1977 & \multicolumn{3}{|c|}{$\begin{array}{l}\text { "in 1977, the Department of Energy (DOE) announced that the Federal } \\
\text { Government would begin accepting and taking title from utilities to spent } \\
\text { nuclear fuel that previously was to be reprocessed"[GAO-EMD-78-97] }\end{array}$} & \\
\hline DOE, 1977 & \multicolumn{3}{|c|}{$\begin{array}{l}\text { DOE declassified the "fact that a nuclear test was conducted using reactor } \\
\text { grade plutonium and that is successfully produced a nuclear yield." [RDD- } \\
\text { 8] }\end{array}$} & \\
\hline NRC, 1977 & \multicolumn{3}{|c|}{$\begin{array}{l}\text { NRC terminated proceedings on the GEIS for MOX fuel and plutonium } \\
\text { recycling, stalling Barnwell. }\end{array}$} & \\
\hline
\end{tabular}




\begin{tabular}{|c|c|c|c|}
\hline $\begin{array}{l}\text { IAEA, physical } \\
\text { protection, } \\
\text { INFCIRC/225/ } \\
\text { Rev1, } 1978\end{array}$ & & $\begin{array}{l}80 \% \text { Pu } 238 \text { criterion } \\
\text { appears (was not in } \\
1975 \text { version) }\end{array}$ & $\begin{array}{l}\text { U235 enrichment } \\
\text { criteria at } 10 \% \text { and } \\
20 \% \text { retained }\end{array}$ \\
\hline \multicolumn{4}{|c|}{ Nuclear Non-Proliferation Act of 1978.} \\
\hline \multicolumn{4}{|c|}{$\begin{array}{l}1979 \text { - "Congress authorized the U.S. Department of Energy to build the Waste Isolation Pilot Plant } \\
\text { (WIPP) near Carlsbad, New Mexico, as a research and development facility for the safe management } \\
\text { storage, and disposal of waste contaminated with transuranic radioisotopes."[SAND99-2719J] }\end{array}$} \\
\hline \multicolumn{4}{|c|}{$\begin{array}{l}\text { Three Mile Island, March } 28,1979 \text {. } \\
\text { CONAES1979 noted that as of January } 1,1979 \text {, there were } 72 \text { operating reactors, } 92 \text { with construction } \\
\text { permits, } 4 \text { with limited work authorizations, and } 30 \text { on order, for a total of } 198 \text {. Today, there are } 104 \text { in } \\
\text { operation. TMI and the cancelation of reactors decreased the emphasis on uranium supplies and } \\
\text { plutonium recycling. }\end{array}$} \\
\hline \multicolumn{4}{|c|}{1980, FFTF went critical } \\
\hline $\begin{array}{l}\text { International } \\
\text { Nuclear Fuel } \\
\text { Cycle Evaluation, } \\
\text { January } 1980 \\
\text { [INFCE1980] }\end{array}$ & \multicolumn{3}{|c|}{$\begin{array}{l}\text { No country with spent fuel had selected "no-reprocessing decision", all had selected "decision to } \\
\text { reprocess", "deferred decision", or "fuel transfer decision". } \\
\text { These four categories appear in INFCE, the author does not know why they chose to categorize } \\
\text { in this manner. } \\
\text { "The extent to which the possibilities of misuse vary as between fuel cycles is not easy to judge. } \\
\text { Taking into account the qualitative nature of the evaluation, the different stages of development of } \\
\text { the various fuel cycles, the extent which complete fuel cycles are present within individual countries } \\
\text { and the evolutionary nature of the technical safeguards and institutional improvements that may be } \\
\text { implemented, no single judgement about the risk of division from the different cycles can be made } \\
\text { that is valid both now and for the future."[INFCE1980] } \\
\text { The report identified ways to reduce risk: co-location, co-conversion ("production of mixed oxide } \\
\text { from mixed uranium and plutonium solutions, pure plutonium no longer exists in the fuel cycle"), } \\
\text { storage and transport of plutonium as mixed oxide, co-processing ("modification of reprocessing in } \\
\text { which plutonium does not exist in separate form but emerges from the reprocessing plant in a mixed } \\
\text { stream of uranium and plutonium nitrate suitable for co-conversion"), denaturing (for U233), pre- } \\
\text { irradiation (at fabrication site, before transport to reactor), spiking, partial processing ("a } \\
\text { modification of reprocessing in which fission products that are radioactive are not completely } \\
\text { separated from the plutonium"). [INFCE1980] }\end{array}$} \\
\hline $\begin{array}{l}\text { National } \\
\text { Proliferation and } \\
\text { Civilian Nuclear } \\
\text { Power, } \\
\text { June } 1980 \\
{[\text { NASAP1980] }}\end{array}$ & \multicolumn{3}{|c|}{$\begin{array}{l}\text { "All nuclear fuel cycles would entail some proliferation risks; there is no technical } \\
\text { "fix"."[NASAP1980] } \\
\text { "Nevertheless, the light-water reactor fuel cycle with spent fuel discharged to interim storage does } \\
\text { not involve weapons-usable material in any part of the fuel cycle and is a more proliferation- } \\
\text { resistant nuclear power fuel cycle than other fuel cycles which involve highly enriched uranium or } \\
\text { pure plutonium."[NASAP1980] } \\
\text { This is the first explicit mention found to "pure plutonium" as opposed to merely "plutonium". } \\
\text { It evaluated HEU and "pure plutonium" as having lower proliferation resistance than once- } \\
\text { through. It does not make the same comparison regarding impure or diluted plutonium. }\end{array}$} \\
\hline $\begin{array}{l}\text { R. W. Reagan } \\
\text { October } 8,1981 \\
\text { [Reagan } 1981]\end{array}$ & & $\begin{array}{l}\text { "lifting the indefinite ban which previous } \\
\text { administrations placed on commercial } \\
\text { reprocessing activities"[Reagan1981] }\end{array}$ & \\
\hline $\begin{array}{l}\text { Barnwell } \\
\text { terminated, } \\
\text { October } 15,1981\end{array}$ & & $\begin{array}{l}\text { "Convinced that the project could not proceed } \\
\text { on a private basis and that reprocessing was } \\
\text { commercially impracticable, Allied halted the } \\
\text { Barnwell project." [CRS2008] }\end{array}$ & \\
\hline $\begin{array}{l}\text { R. W. Reagan, } \\
\text { NSDD-39, } \\
\text { June } 4,1982\end{array}$ & \multicolumn{2}{|c|}{$\begin{array}{l}\text { "President Reagan approved the United States Policy on Foreign } \\
\text { Reprocessing of Plutonium Subject to U.S. Control as National Security } \\
\text { Decision Directive } 39 \text { (June } 4,1982 \text { ). Although specific details of the } \\
\text { directive have not been declassified, the policies approved pertain to the } \\
\text { nonproliferation and statutory conditions for safeguards and physical } \\
\text { security for a continued commitment by Japan to nonproliferation } \\
\text { efforts."[CRS2008, citing an unclassified portion of the document] }\end{array}$} & \\
\hline $\begin{array}{l}\text { CRBR terminated, } \\
\text { Oct } 26,1983\end{array}$ & $\begin{array}{l}\text { Senate kills CRBR by } \\
\text { vote of } 56-40 \\
\text { [NWeek1983] }\end{array}$ & & \\
\hline
\end{tabular}




\begin{tabular}{|c|c|c|c|c|}
\hline $\begin{array}{l}1992-\text { DOE decla } \\
\text { 1as nonproliferatio }\end{array}$ & $\begin{array}{l}\text { ied the statement } \\
\text { oncerns about } \mathrm{Np}\end{array}$ & $\begin{array}{l}\mathrm{Np} 237 \text { "can be } \\
\text { [RDD-8] }\end{array}$ & for a nuclear ex & ve device" and \\
\hline $\begin{array}{l}\text { G. H. W. Bush } \\
\text { statement and } \\
\text { companion fact } \\
\text { sheet, } \\
\text { July 13, } 1992 \\
\text { [Bush1992, } \\
\text { Bush1992a] }\end{array}$ & & & $\begin{array}{l}\text { "decision not to produc } \\
\text { enriched uranium for nu } \\
\text { purposes" [Bush1992] } \\
\text { "The United States shal } \\
\text { or highly enriched uran } \\
\text { explosive purposes. Thi } \\
\text { encourage countries in } \\
\text { as the Middle East and } \\
\text { similar actions, such as } \\
\text { May } 1991 \text { Middle East } \\
\text { The United States will } \\
\text { support for concrete me } \\
\text { production or acquisitio } \\
\text { nuclear materials in Sou } \\
\text { Peninsula, or other area } \\
\text { increase the risk of prol }\end{array}$ & $\begin{array}{l}\text { plutonium and highly } \\
\text { lear explosive } \\
\text { not produce plutonium } \\
\mathrm{m} \text { for nuclear } \\
\text { step is intended to } \\
\text { gions of tension, such } \\
\text { outh Asia, to take } \\
\text { ose proposed in the } \\
\text { ms control initiative. } \\
\text { ek further multilateral } \\
\text { sures to discourage } \\
\text { of weapons-usable } \\
\text { Asia, the Korean } \\
\text { where they would } \\
\text { eration.'[Bush1992a] }\end{array}$ \\
\hline $\begin{array}{l}\text { W. J. Clinton, } \\
\text { statement, } \\
\text { September } 27 \text {, } \\
1993 \\
\text { [Clinton1993a] }\end{array}$ & & $\begin{array}{l}\text { "The United States } \\
\text { does not encourage the } \\
\text { civil use of plutonium } \\
\text { and, accordingly, does } \\
\text { not itself engage in } \\
\text { plutonium } \\
\text { reprocessing for either } \\
\text { nuclear power or } \\
\text { nuclear explosive } \\
\text { purposes." } \\
\text { [Clinton1993a] }\end{array}$ & $\begin{array}{l}\text { Eliminate existing US } \\
\text { and foreign stockpiles } \\
\text { of plutonium } \\
\text { Prevent future } \\
\text { stockpiling }\end{array}$ & $\begin{array}{l}\text { Eliminate existing US } \\
\text { and foreign stockpiles } \\
\text { of HEU } \\
\text { Minimize civil use of } \\
\text { HEU }\end{array}$ \\
\hline $\begin{array}{l}\text { National Academy } \\
\text { of Sciences report } \\
\text { on disposition of } \\
\text { weapons } \\
\text { plutonium, } 1994 \\
\text { [NAS1994] }\end{array}$ & $\begin{array}{l}\text { "The Spent Fuel Standar } \\
\text { to meet a "spent fuel stan } \\
\text { use as the much larger an } \\
\text { weapons plutonium more } \\
\text { safeguards problem inde } \\
\text { beyond the spent fuel sta } \\
\text { would not offer substanti } \\
\text { approach with the global } \\
\text { As articulated in thi } \\
\text { explicitly to be appl } \\
\text { radiation field, chen } \\
\text { "Beyond the Spent Fuel } \\
\text { endorsement of today's st } \\
\text { substantially less accessi } \\
\text { does pose a security risk, } \\
\text { taken to reduce the prolif } \\
\text { civilian, separated and un } \\
\text { time (see Chapter } 6 \text { )." [N }\end{array}$ & $\begin{array}{l}\text { Options for the long-te } \\
\text { dard" that is, to make } t \\
\text { d growing stock of pluto } \\
\text { accessible would mean } \\
\text { initely. Conversely, the } \\
\text { ndard to eliminate the ex } \\
\text { al additional security ben } \\
\text { stock of civilian plutonit } \\
\text { s document and the follo } \\
\text { ied to disposition of wear } \\
\text { nical, mass/size consider } \\
\text { standard. The spent fuel } \\
\text { andards of management } \\
\text { ble for use in weapons th } \\
\text { and that risk increases w } \\
\text { eration risks posed by all } \\
\text { iseparated; the need for s } \\
\text { AS1994] }\end{array}$ & $\begin{array}{l}\text { m disposition of weapon } \\
\text { is plutonium roughly as } \\
\text { ium in civilian spent fue } \\
\text { hat this material would ce } \\
\text { osts, complexities, risks, } \\
\text { ess weapons plutonium c } \\
\text { fits unless society were } \\
\text { m.'[NAS1994] } \\
\text {-up } 1995 \text { document, the } \\
\text { ons plutonium. It incorp } \\
\text { tions, and inventories. } \\
\text { tandard should not be int } \\
\text { or plutonium in spent fue } \\
\text { n separated plutonium, p } \\
\text { th time, as noted above. } \\
\text { of the world's plutonium } \\
\text { ch steps exists already, a }\end{array}$ & $\begin{array}{l}\text { plutonium should seek } \\
\text { accessible for weapons } \\
\text { Options that left the } \\
\text { tinue to pose a unique } \\
\text { ad delays of going } \\
\text { mpletely or nearly so } \\
\text { epared to take the same } \\
\text { pent fuel standard" is } \\
\text { ates isotopic, heat, } \\
\text { preted as an } \\
\text { however. Although } \\
\text { tonium in spent fuel } \\
\text { arther steps should be } \\
\text { tocks, military and } \\
\text { d will increase with }\end{array}$ \\
\hline August, 1994 & $\begin{array}{l}\text { EBR-II killed by withdra } \\
\text { [NuclearNews 2004] }\end{array}$ & wal of funding by U.S. C & ngress & \\
\hline January 1997 & DOE ordered FFTF into & standby. & & \\
\hline $\begin{array}{l}\text { May } 28,1998 \text { Paki } \\
\text { "Pakistan had alrea } \\
\text { and thus presumed }\end{array}$ & $\begin{array}{l}\text { built nuclear weap } \\
\text { liable without testin }\end{array}$ & "[Graham2004] & $\begin{array}{l}\text { Less well know1 } \\
\text { it tested them - th }\end{array}$ & $\begin{array}{l}\text { erhaps, is that } \\
\text { were HEU-fueled }\end{array}$ \\
\hline $\begin{array}{l}1998-\text { "The U.S. En } \\
\text { (WIPP), an undergro }\end{array}$ & $\begin{array}{l}\text { ronmental Protectio } \\
\text { nd geologic disposa }\end{array}$ & $\begin{array}{l}\text { Agency (EPA) cer } \\
\text { ystem, complied }\end{array}$ & $\begin{array}{l}\text { ied that the Waste } \\
\text { its regulations." }\end{array}$ & $\begin{array}{l}\text { olation Pilot Plant } \\
\text { ND99-2719J] }\end{array}$ \\
\hline WIPP operational, & $\operatorname{arch} 26,1999$. [DOH & CAO-00-3124] & & \\
\hline $\begin{array}{l}\text { National Energy } \\
\text { Policy, May } 2001 \\
{[\text { NEP2001] }}\end{array}$ & & $\begin{array}{l}\text { "The NEPD Group reco } \\
\text { context of developing a } \\
\text { cycles and next generati }\end{array}$ & $\begin{array}{l}\text { amends that, in the } \\
\text { vanced nuclear fuel } \\
n \text { technologies for }\end{array}$ & \\
\hline
\end{tabular}




\begin{tabular}{|c|c|c|c|}
\hline & & $\begin{array}{l}\text { nuclear energy, the United States should } \\
\text { reexamine its policies to allow for research, } \\
\text { development and deployment of fuel } \\
\text { conditioning methods (such as pyroprocessing) } \\
\text { that reduce waste streams and enhance } \\
\text { proliferation resistance. In doing so, the United } \\
\text { States will continue to discourage the } \\
\text { accumulation of separated plutonium, } \\
\text { worldwide.'[NEP2001, Page 5-22] }\end{array}$ & \\
\hline & & & $\begin{array}{l}\text { Spread of uranium } \\
\text { enrichment } \\
\text { technology } \\
\text { [CRS2007] }\end{array}$ \\
\hline $\begin{array}{l}\text { B. H. Obama, } \\
\text { April 5, } 2009 \\
\text { [Obama2009] }\end{array}$ & \multicolumn{3}{|c|}{$\begin{array}{l}\text { "And to cut off the building blocks needed for a bomb, the United States will seek a new treaty that } \\
\text { verifiably ends the production of fissile materials intended for use in state nuclear weapons. If we } \\
\text { are serious about stopping the spread of these weapons, then we should put an end to the dedicated } \\
\text { production of weapons-grade materials that create them. That's the first step." [Obama2009] } \\
\text { There does not appear to be a fundamental difference from Bush } 41 \text { or Bush } 43 \text {, who both } \\
\text { banned production of weapons-grade material for weapon purposes. Contrast with Clinton's } \\
1993 \text { statement that explicitly forbade plutonium reprocessing for either weapons or civilian } \\
\text { use. } \\
\text { "And we should build a new framework for civil nuclear cooperation, including an international fuel } \\
\text { bank, so that countries can access peaceful power without increasing the risks of proliferation. That } \\
\text { must be the right of every nation that renounces nuclear weapons, especially developing countries } \\
\text { embarking on peaceful programs. And no approach will succeed if it's based on the denial of rights } \\
\text { to nations that play by the rules. We must harness the power of nuclear energy on behalf of our } \\
\text { efforts to combat climate change, and to advance peace opportunity for all people."[Obama2009] }\end{array}$} \\
\hline $\begin{array}{l}\text { GNEP termination } \\
\text { confirmed, April } \\
15,2009\end{array}$ & \multicolumn{3}{|c|}{$\begin{array}{l}\text { "A US Department of Energy spokeswoman has confirmed that the US domestic component of the } \\
\text { Global Nuclear Energy Partnership has been cancelled. "The Department has already decided not to } \\
\text { continue the domestic GNEP program of the last administration," said DOE deputy press secretary } \\
\text { Jen Stutsman in a statement on April } 15 \text {. "The long-term fuel cycle research and development } \\
\text { program will continue but not the near-term deployment of recycling facilities or fast reactors. The } \\
\text { international component of GNEP is under interagency review." [NEInternational, } 4 / 5 / 2009]\end{array}$} \\
\hline $\begin{array}{l}\text { DOE GNEP PEIS } \\
\text { terminated, June } \\
23,2009 . \\
{[\mathrm{DOE} 2009]}\end{array}$ & \multicolumn{3}{|c|}{$\begin{array}{l}\text { "The comments that DOE received included suggestions to prepare a programmatic environmental } \\
\text { impact statement addressing the entire GNEP Program. DOE agreed and on January 4, 2007, } \\
\text { published its Notice of Intent to prepare the Global Nuclear Energy Partnership Programmatic } \\
\text { Environmental Impact Statement (GNEP PEIS) in the Federal Register (72 FR Doc E9-15328 Page } \\
1 \text { of } 2 \text { http://edocket.access. gpo. gov/2009/E9-15328.htm 11/10/2011 FR 331). The public scoping } \\
\text { period for the GNEP PEIS was later extended (72 FR 15871, April 3, 2007) and concluded on June } \\
4,2007 \text {. DOE considered the scoping comments in preparing the Draft GNEP PEIS. The } \\
\text { Draft GNEP PEIS analyzed the potential environmental impacts of expanding nuclear power in the } \\
\text { U.S. using either the existing fuel cycle or various alternative closed and open fuel cycles. DOE's } \\
\text { stated preference in the Draft was to close the fuel cycle, although it did not identify a specific } \\
\text { preferred alternative.'[DOE2009] } \\
\text { "Via this notice, DOE announces that it has decided to cancel the GNEP PEIS because it is no } \\
\text { longer pursuing domestic commercial reprocessing, which was the primary focus of the prior } \\
\text { Administration's domestic GNEP program. The Omnibus Appropriations Act, 2009, provides } \$ 145 \\
\text { million for the continuation of research and development (R\&D) on proliferation-resistant fuel } \\
\text { cycles and waste management strategies. As described in the President's Fiscal Year } 2010 \text { budget } \\
\text { request, the Department's fuel cycle R\&D's focus is on "long-term, science-based R\&D of } \\
\text { technologies with the potential to produce beneficial changes to the manner in which the nuclear } \\
\text { fuel cycle and nuclear waste is managed." [DOE2009] }\end{array}$} \\
\hline $\begin{array}{l}\text { NRC, September } \\
15,2010\end{array}$ & \multicolumn{3}{|c|}{$\begin{array}{l}\text { "The Commission has made a generic determination that, if necessary, spent fuel generated in any } \\
\text { reactor can be stored safely and without significant environmental impacts for at least } 60 \text { years } \\
\text { beyond the licensed life for operation (which may include the term of a revised or renewed license) } \\
\text { of that reactor in a combination of storage in its spent fuel storage basin and at either onsite or } \\
\text { offsite independent spent fuel storage installations. Further, the Commission believes there is } \\
\text { reasonable assurance that sufficient mined geologic repository capacity will be available to dispose } \\
\text { of the commercial high-level radioactive waste and spent fuel generated in any reactor when } \\
\text { necessary." [NRC2010] }\end{array}$} \\
\hline
\end{tabular}




\subsection{Topic Evolution in Three Eras}

Table 4 shows another way to observe how certain topics have evolved over time. The first two time periods in Table 4 were dominated by the Carter and Clinton administrations. Furthermore, Carter and Clinton's statements - while not having legal force - contributed to the termination of projects and spawned various analyses and studies.

In addition to information presented earlier in this chapter, Table 4 notes two other questions.

First is the explicit question of whether waste from recycled used fuel is easier to dispose of than direct disposal of unprocessed used fuel. At the request of Congress, GAO looked at this in 1978.[EMD-81-78] They concluded

"Thus, when considering only the impact on nuclear waste disposal, it makes sense that spent fuel not be buried in a repository but instead be reprocessed to recover the valuable uranium and plutonium."

Their reasons were as follows: reprocessing allows reduction of hazard to "naturally occurring uranium ore in about 600 to 1000 years", ability to tailor waste form to repository site, lower repository area, lower cost if reprocessing, $\mathrm{Pu}$ and $\mathrm{U}$ as energy resource, proliferation hazard of buried $\mathrm{Pu}$ and $\mathrm{U}$. At the time, DOE was "studying several types of geological media (i.e., salt, basalt, granite, and tuffs), attempting to determine which is best suited for a repository."

This report is also the first mention found of 50 years of repository operations as a minimum period of retrievability of spent fuel if directly disposed in a repository. This shows that that time period was being discussed prior to the NWPA of 1982.

Past events are often taken as indicative of future performance. DOE's cleanup effort has focused on radioactive waste volume reduction, not hazard reduction.[GAO-03-593] So, it is perhaps unsurprising that criticism of recycling in candidate advanced fuel cycle options includes an increase in waste volume. Likewise, the orphaning of fuels around the DOE complex has not increased confidence in creating more new fuels. For example, there are 12-foot plutonium fuel rods fabricated for FFTF in storage at Hanford that do not have a disposition pathway.[GAO-05-665]

Second is, assuming recycle of some sort occurs, the explicit question of which transmutation approach is best. The GAO looked at this in 1993.[GAO-RCED-94-16s]. They compared five transmutation approaches from ANL, BNL, and Hanford - fast reactors, accelerators, and a pebble bed HTGR. The evaluation criteria were transmutation (or not) of plutonium, minor actinides, Tc99, and I-129; development cost; operating cost; estimated schedule for development and implementation; estimated time required to transmute existing spent fuel; and the major technical challenges to overcome. In Chapter 4, the current author provides a summary table of that 1993 report. 
Table 4 of report. Comparison of Topics in Three Eras.

\begin{tabular}{|c|c|c|c|}
\hline & Late $1970 \mathrm{~s}$ - Early $1980 \mathrm{~s}$ & $1990 \mathrm{~s}$ & Now \\
\hline $\begin{array}{l}\text { Presidential } \\
\text { policy }\end{array}$ & $\begin{array}{l}\text { "Alternative designs to } \\
\text { plutonium breeder"/ "Defer ... } \\
\text { reprocessing and recycle of } \\
\text { plutonium"/"Preventing . direct } \\
\text { access to plutonium, highly } \\
\text { enriched uranium, or other } \\
\text { weapons useable material" }\end{array}$ & $\begin{array}{l}\text { "does not encourage the civil use } \\
\text { of plutonium and, accordingly, } \\
\text { does not itself engage in plutonium } \\
\text { reprocessing for either nuclear } \\
\text { power or nuclear explosive } \\
\text { purposes." }\end{array}$ & \\
\hline $\begin{array}{l}\text { Key policy } \\
\text { statement }\end{array}$ & $\begin{array}{l}\text { Carter's April 7, } 1977 \text { statement } \\
\text { and corresponding classified } \\
\text { directive, which was } \\
\text { declassified in } 1994\end{array}$ & $\begin{array}{l}\text { Clinton's Sept } 27,1993 \text { statement } \\
\text { and corresponding classified } \\
\text { directive, still classified }\end{array}$ & \\
\hline $\begin{array}{l}\text { Projects } \\
\text { eventually } \\
\text { canceled }\end{array}$ & $\begin{array}{l}\text { Barnwell, October } 1981 \\
\text { CRBR, October } 1983\end{array}$ & $\begin{array}{l}\text { EBR-II, August } 1994 \\
\text { FFTF, January } 1997\end{array}$ & Yucca Mountain? \\
\hline HEU status & \multicolumn{3}{|c|}{$\begin{array}{l}\text { HEU fuel unambiguously against Congressional and Presidential policy but not legally forbidden for power } \\
\text { reactors }\end{array}$} \\
\hline \multirow[t]{4}{*}{ Pu status } & \multicolumn{2}{|c|}{ Pu separation against U.S. policy } & \\
\hline & \multicolumn{3}{|c|}{ Ability of reactor-grade $\mathrm{Pu}$ to be used in a weapon had been declassified in 1967} \\
\hline & \multicolumn{3}{|c|}{$80 \%$ Pu238 exempted from international safeguards by 1972} \\
\hline & $\begin{array}{l}\text { Little evidence that minor } \\
\text { actinides, fission products, } \\
\text { uranium were considered as } \mathrm{Pu} \\
\text { additives in this context. }\end{array}$ & $\begin{array}{l}\text { OTA1994 indicates that } \mathrm{Pu}+ \\
\text { minor actinides }+ \text { lanthanides }+ \\
30 \% \text { uranium was viewed by } \\
\text { some as outside the policy }\end{array}$ & $\begin{array}{l}\text { NNSA labs have published FOM1 } \\
\text { (subnational) and FOM2 (national), } \\
\text { allowing quantitative comparisons }\end{array}$ \\
\hline $\begin{array}{l}\text { Self- } \\
\text { protecting }\end{array}$ & $\begin{array}{l}\text { In } 1978 \text {, IAEA added } 100 \mathrm{rad} / \mathrm{hr} \\
\text { criterion for physical protection } \\
\text { [INFCIRC/225/rev1] } \\
\text { CONAES1979 and others } \\
\text { downplayed alternatives to } \\
\text { "separation of plutonium in pure } \\
\text { form" because "Such processes } \\
\text { are not now available and would } \\
\text { reguire development." }\end{array}$ & $\begin{array}{l}\text { In 1995, OTA used a chemical } \\
\text { and radiological spent fuel } \\
\text { standard, without using that } \\
\text { language[OTA-ISS-615] } \\
\text { In 1994-1995, the NAS was } \\
\text { articulating and using this } \\
\text { standard regarding disposition of } \\
\text { weapons plutonium. }\end{array}$ & $\begin{array}{l}\text { "plutonium in its final dispositioned } \\
\text { forms should be roughly as difficult to } \\
\text { acquire, process, and utilize in nuclear } \\
\text { weapons as is the plutonium in typical } \\
\text { spent fuel from civilian power } \\
\text { plants."[NAS2000] } \\
100 \mathrm{rem} / \mathrm{hr} \text { standard apparently } \\
\text { changing to } 500 \mathrm{rad} / \mathrm{hr} \text {.[Bathke2009] }\end{array}$ \\
\hline $\begin{array}{l}\text { Fast reactor } \\
\text { types } \\
\text { considered }\end{array}$ & Full recycle breeder & $\begin{array}{l}\text { Full recycle breeder } \\
\text { Full recycle burner }\end{array}$ & $\begin{array}{l}\text { Full recycle breeder } \\
\text { Full recycle burner } \\
\text { "Breed and burn" once thru }\end{array}$ \\
\hline \multirow{4}{*}{$\begin{array}{l}\text { Recycling } \\
\text { topics other } \\
\text { than } \\
\text { proliferation }\end{array}$} & \multicolumn{2}{|c|}{ Energy content focused on only uranium and $\mathrm{Pu}$} & $\begin{array}{l}\text { Energy content of all actinides } \\
\text { guantified }\end{array}$ \\
\hline & $\begin{array}{l}\text { Following the once-through } \\
\text { policy of Carter, Yucca Mtn was } \\
\text { a candidate in } 1982 \text {, selected in } \\
1987\end{array}$ & $\begin{array}{l}\text { Yucca Mtn was the sole basis for } \\
\text { judging waste benefits from } \\
\text { recycling. }\end{array}$ & Yucca Mountain repository cancelled \\
\hline & $\begin{array}{l}\text { "heat output is a more important } \\
\text { factor than the physical volume } \\
\text { of the waste in determining the } \\
\text { amount of repository space } \\
\text { needed for disposal"'[OTA-O- } \\
171 \text { ] }\end{array}$ & $\begin{array}{l}\text { GTCC longevity vs. } \\
\text { radioactivity concentration, } \\
\text { possibility of Cs } 137 \mathrm{Sr} 90 \\
\text { separation [OTA-BP-O-50] } \\
\text { Some critics downplayed IFR } \\
\text { possible contribution because } \\
\text { deployment would be too slow } \\
\text { [OTA-BP-ENV-126] }\end{array}$ & $\begin{array}{l}\text { Heat an issue in all candidate disposal } \\
\text { environments (some have quantitative } \\
\text { evaluation metrics) }\end{array}$ \\
\hline & $\begin{array}{l}\text { Radiotoxicity the metric in } \\
\text { international and national studies, } \\
\text { e.g., OTA-O-171 } \\
\text { But, dose and cumulative release } \\
\text { were metrics of interest to the } \\
\text { EPA and NRC from the start of } \\
\text { repository } \\
\text { considerations.[DOE/EIS-0046F] }\end{array}$ & $\begin{array}{l}\text { Radiotoxicity and Yucca Mtn } \\
\text { hypothetical doses }\end{array}$ & $\begin{array}{l}\text { Radiotoxicity and hypothetical doses } \\
\text { in generic disposal environments } \\
\text { (tuff, salt, granite, clay, borehole) }\end{array}$ \\
\hline
\end{tabular}




\subsection{Cost and Schedule Estimates Found}

Two types of data were encountered in the course of this work, which are captured here. (The report was not intended to examine cost.) The first is a time line for WIPP. There was 28 years from first proposal of the Carlsbad, NM area for a nuclear waste site until WIPP became operational.[DOE/CAO-00-3124]

1971 - "Carlsbad's involvement with the WIPP began in the fall of 1971 when State Senator Joe Gant, Jr. learned that the Atomic Energy Commission had rejected the Lyons, Kansas salt mine for a proposed nuclear waste disposal site. Gant called his friend, Congressman Harold Runnels, and asked, "Why not Carlsbad?"[DOE/CAO-00-3124]

1973 - "Selection of the Delaware Basin in southeastern New Mexico as a potential disposal site for radioactive waste" [SAND99-2719J]

1979 - "Congress authorized the U.S. Department of Energy to build the Waste Isolation Pilot Plant (WIPP) near Carlsbad, New Mexico, as a research and development facility for the safe management storage, and disposal of waste contaminated with transuranic radioisotopes."[SAND99-2719J]

1998 - "The U.S. Environmental Protection Agency (EPA) certified that the Waste Isolation Pilot Plant (WIPP), an underground geologic disposal system, complied with its regulations."[SAND992719J]

1999 - WIPP operational on March 26, 1999 [DOE-CAO-00-3124]

The second type of data is time-dependent cost estimates. These are not complete, but do illustrate that cost estimates are time dependent. Table 5 provides the data. Figure 2 graphs them.

Note that the GAO's final estimate for Yucca Mountain [GAO-10-48] is much lower than DOE's. They state "Our analysis of DOE's cost projections found that the Yucca Mountain repository would cost from $\$ 41$ billion to $\$ 67$ billion (in 2009 present value) for disposing of 153,000 metric tons of nuclear waste."

They further state in a footnote, "Our cost range for a permanent repository differs from DOE's most recent estimate of $\$ 96$ billion for the following reasons: First, our cost range is in 2009 present value, while DOE uses 2007 constant dollars, which are not discounted. Our present value analysis reflects the time value of money - costs incurred in the future are worth less today - so that streams of future costs become smaller. Second, our cost range does not include about $\$ 14$ billion in previously incurred costs. Third, our cost range is for 153,000 metric tons of nuclear waste while DOE's estimated cost is for 122,100 metric tons. Finally, we use a range while DOE provides a point estimate."

The same GAO report examined two alternatives: centralized storage and onsite storage.

- "The estimated cost of implementing centralized storage for 100 years ranges from $\$ 15$ billion to $\$ 29$ billion for 153,000 metric tons of nuclear waste, and the total cost ranges from $\$ 23$ billion to $\$ 81$ billion if the nuclear waste is centrally stored and then disposed in a geologic repository."

- "The estimated cost to continue storing 153,000 metric tons of nuclear waste on site for 100 years range from $\$ 13$ billion to $\$ 34$ billion, and total costs would range from $\$ 20$ billion to $\$ 97$ billion if the nuclear waste is stored on site for 100 years and then disposed in a geologic repository." 
Table 5 of report. Cost Data Assembled During the Course of this Study (Billions of Then-Current Dollars)

\begin{tabular}{|c|c|c|c|c|c|c|}
\hline Year & $\begin{array}{l}\text { Clinch } \\
\text { River } \\
\text { Breeder } \\
\text { Reactor } \\
\text { (CRBR) }\end{array}$ & $\begin{array}{l}\text { Generic } \\
\text { geologic } \\
\text { repository }\end{array}$ & $\begin{array}{c}\text { Waste } \\
\text { Isolation } \\
\text { Pilot } \\
\text { Project } \\
\text { (WIPP) }\end{array}$ & $\begin{array}{l}\text { Yucca } \\
\text { Mountain } \\
\text { geologic } \\
\text { repository }\end{array}$ & $\begin{array}{l}\text { 5-tonne } \\
\text { spent } \\
\text { fuel } \\
\text { storage } \\
\text { at SRS }\end{array}$ & References \\
\hline 1970 & $\$ 0.7$ & & & & & GAO-EMD-79-62 \\
\hline 1974 & $\$ 1.7$ & & & & & GAO-EMD-79-62 \\
\hline 1976 & $\$ 1.9$ & $\$ 0.2$ & $\$ 0.1$ & & & $\begin{array}{l}\text { GAO-EMD-79-62, GAO-EMD-77- } \\
41\end{array}$ \\
\hline 1978 & $\$ 2.2$ & $\$ 0.6$ & $\$ 0.2$ & & & GAO-EMD-78-49 \\
\hline 1979 & $\$ 2.6$ & $\$ 1.0$ & $\$ 0.3$ & & $\$ 0.3$ & $\begin{array}{l}\text { GAO-EMD-79-62, GAO-EMD-79- } \\
82\end{array}$ \\
\hline 1981 & $\$ 3.2$ & $\$ 3.1$ & $\$ 0.4$ & & & $\begin{array}{l}\text { GAO-EMD-81-83, GAO-EMD-81- } \\
78\end{array}$ \\
\hline 1982 & $\$ 3.4$ & & $\$ 0.5$ & & & GAO-EMD-82-131 \\
\hline 1983 & $\$ 3.6$ & & $\$ 0.6$ & & & GAO-RCED-83-74 \\
\hline 1987 & & & $\$ 1.3$ & $\$ 25.0$ & & DOE/RW-0236 \\
\hline 1989 & & & $\$ 1.9$ & $\$ 23.8$ & & $\mathrm{DOE} / \mathrm{RW}-0236$ \\
\hline 1990 & & & $\$ 2.4$ & $\$ 25.6$ & & $\mathrm{DOE} / \mathrm{RW}-0295 \mathrm{P}$ \\
\hline 1995 & & & $\$ 6.5$ & $\$ 33.1$ & & DOE/RW-0479 \\
\hline 1996 & & & $\$ 8.0$ & $\$ 36.3$ & & GAO-RCED-96-146 \\
\hline 1998 & & & & $\$ 43.7$ & & $\mathrm{DOE} / \mathrm{RW}-0510$ \\
\hline 2001 & & & & $\$ 57.5$ & & DOE/RW-0533 \\
\hline 2008 & & & & $\$ 96.2$ & & DOE/RW-0591 \\
\hline
\end{tabular}

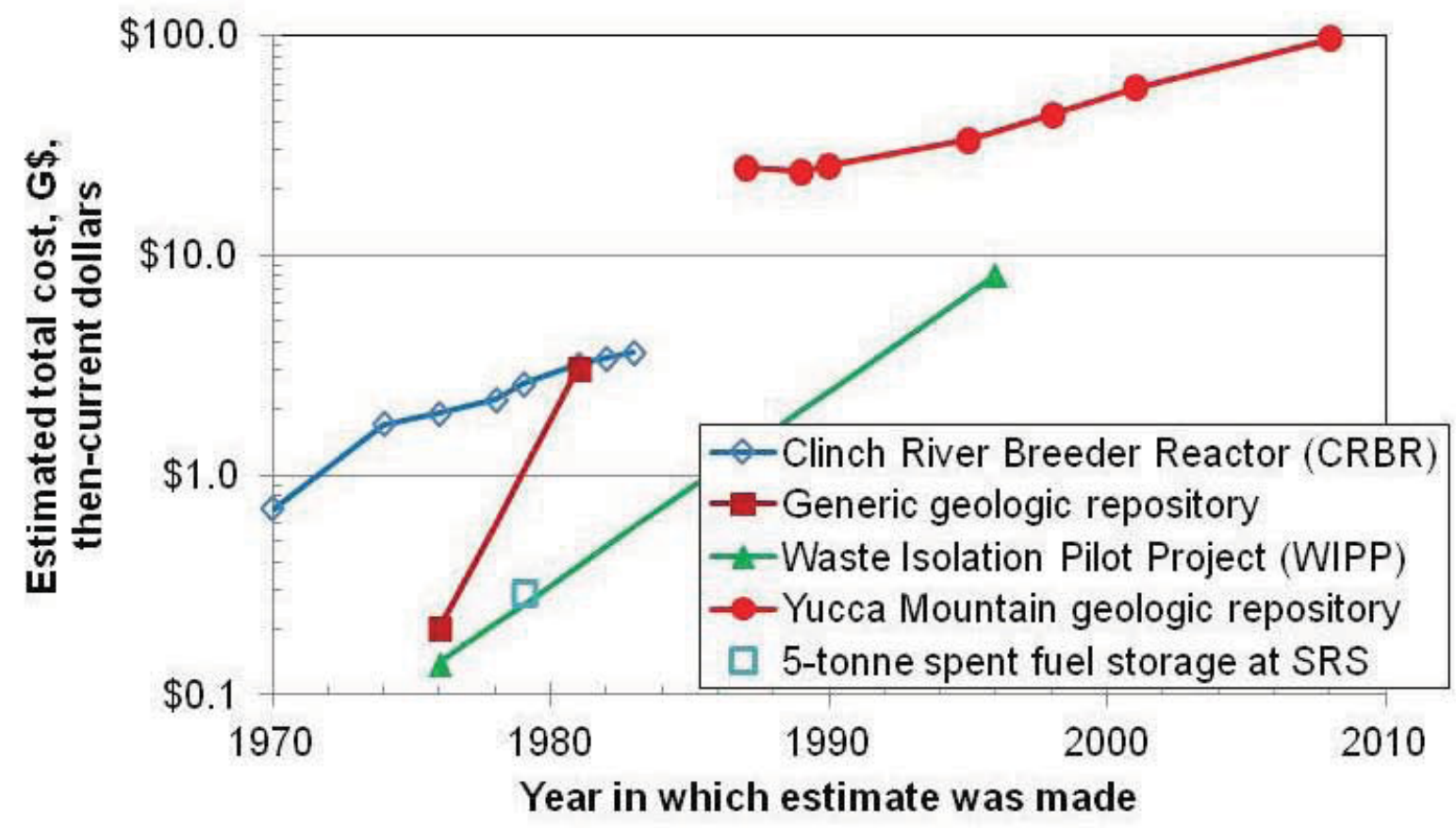

Figure 2. Cost data encountered during the course of this study (billions of then-current dollars). 


\section{LIST OF REFERENCES}

The documents consulted for this report are listed here in chronological order. Most have been assembled electronically. ${ }^{\mathrm{q}}$ Laws and ratifications by Congress are in bold text. ${ }^{\mathrm{T}}$

Many were examined to detect policy changes or the existence of policy documents. For example, Congressional Research Service (CRS), Office of Technology Assessments (OTA), and General Accounting Office (GAO) are done by people with ready access to policy documents. Said another way, if CRS and OTA were unaware of policy changes in a time period, it is reasonable to assume that there were not any. They are also attuned to policy differences between Congress and the President.

The author searched all OTA and GAO reports over the relevant time period for any report that might be relevant to the topics of this study.

There is no known database of all CRS reports; commentators on the web advocate for creation of one but the CRS' position is that that is up to Congress to decide. Therefore, the author does not know if important CRS documents have been missed.

Documents referenced in the summary, chapter 1, or chapter 2 of this document are assigned a tag such as [Einstein 1905]. About 40\% of the documents have text extracted in chapter 4.

Just reading the title of difference documents, grouped by Presidential Administrations and Congresses, illustrates the key topics in each time period. For example, there are a host of documents associated with CRBR and Barnwell.

This chronological list of references does not include NRC 10CFRs, which are included as part of Chapter 4, because they are effectively date-less.

\section{Early}

- [Einstein1905] A. Einstein, Does the Inertia of a Body Depend on Its Energy-Content, September 27, 1905.

1933-1952, Roosevelt and Truman Administration and the $73^{\text {th }}$ to $82^{\text {th }}$ Congresses

- [Einstein 1939] A. Einstein, letter to F. D. Roosevelt, August 2, 1939.

- [Truman1945] Harry S. Truman, “Atomic Bombing of Hiroshima Announcement,” August 6, 1945

- [Smyth1945] Henry DeWolf Smyth, “Atomic Energy for Military Purposes - The Official Report on the Development of the Atomic Bomb under the Auspices of the United States Government, 1940-1945," report, August 12, 1945.

- [AEA1946] Atomic Energy Act of 1946, August 1, 1946.

1953-1960, Eisenhower Administration and the $83^{\text {th }}$ to $86^{\text {th }}$ Congresses

- [AEA1954] Atomic Energy Act of 1954, as amended (P.L. 83-703), August 30, 1954.

q. The exceptions are most of the books cited. The key large reports NASAP1980 and INFCE1980 are included electronically, thanks to past scanning by J. Gehin et al.

r. Often in other reports, titles of books and names of journals are put in bold text. However, for this list, to give emphasis solely to U.S. laws, only the names of Administrations, the number of Congresses, and the names of laws are in bold. 
- Dwight D. Eisenhower, "Statement by the President Announcing Additional Steps to Accelerate the Development of Nuclear Power Abroad," November 18, 1956.

- [NAS1957] National Academy of Sciences, "The Disposal of Radioactive Waste on Land Report of the Committee on Waste Disposal of the Division of Earth Sciences," Publication 519 , April 1957

- International Atomic Energy Agency Participation Act of 1957 (P.L. 85-177), August 28, 1957.

1961-1968, Kennedy and Johnson Administrations and the $87^{\text {th }}$ to $90^{\text {th }}$ Congresses

- [AEC1962] United States Atomic Energy Commission, "Civilian Nuclear Power - a Report to the President - 1962," Washington DC, November 20, 1962, http://energyfromthorium.com/msrp/cnp1962/

- "The Public Papers of President John F. Kennedy," www.jfklink.com/speeches/jfk/publicpapers searched for anything regarding "energy", "nuclear", or "plutonium".

- [Johnson 1966] Lyndon B. Johnson, "Statement by the President on the First Privately Owned Facility for Reprocessing Fuel from Nuclear Powerplants," April 19, 1966.

1969-1976, Nixon and Ford Administrations and the $91^{\text {st }}$ to $94^{\text {th }}$ Congresses

- IAEA, "Treaty on the Non-Proliferation of Nuclear Weapons," report INFCIRC/140, April 22, 1970.

- [Nixon1971] Richard Nixon, "Special Message to the Congress on Energy Resources," June 4, 1971.

- [INFCIRC/153] IAEA, "The Structure and Content of Agreements Between the Agency and States Required in Connection with the Treaty on the Non-Proliferation of Nuclear Weapons," report INFCIRC/153, June 1972.

- [EnergyReorganizationAct1974] Energy Reorganization Act of 1974, as amended (P.L. 93438), October 11, 1974.

- GAO, "Elmer B. Staats, "Comptroller General of the United States, Before the Joint Economic Committee on the Liquid Metal Fast Breeder Reactor Program - Past, Present, and Future," testimony, April 30, 1975.

- GAO, "The Liquid Metal Fast Breeder Reactor: Promises and Uncertainties," report GAO-OSP76-1, July 31, 1975.

- [INFCIRC/225] IAEA, "The Physical Protection of Nuclear Material," report INFCIRC/225, September 1975.

- GAO, "Improvements Needed in the Land Disposal of Radioactive Wastes - A Problem of Centuries," report RED-76-54, January 12, 1976.

- GAO, "Statement of Paul G. Dembling, General Counsel, Before the Joint committee on Atomic Energy on the Proposed Contract for the Clinch River Breeder Reactor Project," testimony, April 14, 1976. 
- [GAO-ID-76-60] GAO, "Assessment of U.S. and International Controls over the Peaceful Uses of Nuclear Energy,” report ID-76-60, September 14, 1976.

- "Memorandum of Conversation" - President Ford; Louis deGuiringaud, Minister of Foreign Affairs of France; Dr. Henry A. Kissinger, Secretary of State Brent Scowcroft, Assistant to the President for National Security Affairs; Amb. Jacques Kosciusko-Morizet, Ambassador of France, October 1, 1976.

- [Ford1976] Gerald R. Ford, "Radio Address on Peace" / "Statement on Nuclear Policy," Presidential Documents, vol. 12, no. 44, pp. 1626-1627, October 28, 1976.

\section{7-1980, Carter Administration and the $95^{\text {th }}$ to $96^{\text {th }}$ Congresses}

- [Ford/MITRE1977] Nuclear Energy Policy Study Group, Nuclear Power Issues and Choices, Ford Foundation, 1977.

- $\quad$ [PD/NSC-8] Jimmy Carter, "Nuclear Nonproliferation Policy," PD/NSC-8, March 24, 1977, declassified on March 15, 1994.

- [Carter1977] Jimmy Carter Library, Records of the Speech Writer's Office, Statement on Nuclear Power Policy, April 7, 1977.

- [Carter1977a] Jimmy Carter, "Nuclear Non-Proliferation - Message to Congress," April 27, 1977.

- Jimmy Carter, "Nuclear Non-Proliferation Fact Sheet on the Proposed Nuclear Non-Proliferation Policy Act of 1977," April 27, 1977.

- Jimmy Carter, “Conventional Arms Transfer Policy,” PDD-13, May 13, 1977.

- GAO, "Statement of Monte Canfield, Jr., Director Energy and Minerals Division; Before the Subcommittee on Energy and the Environment; House Committee on Interior and Insular Affairs on Institutional and Jurisdictional Issues in Nuclear Waste Management," May 20, 1977.

- OTA, "Nuclear Proliferation and Safeguards," report OTA-E-48, June 1977.

- Department of Energy Organization Act of 1977 (P.L. 95-91), August 4, 1977.

- [GAO-EMD-77-41] GAO, "Nuclear Energy's Dilemma: Disposing of Hazardous Radioactive Waste Safely," report EMD-77-41, September 9, 1977.

- Jimmy Carter, "International Nuclear Fuel Cycle Evaluation Remarks at the First Plenary Session of the Organizing Conference," speech, October 19, 1977.

- GAO, "Review of the Present Status of the Clinch River Breeder Reactor Project," report EMD78-49, March 6, 1978.

- [NNPA1978] The Nuclear Non-Proliferation Act of 1978 (P.L. 95-242), March 10, 1978.

- [Carter1978] Jimmy Carter, "Nuclear Non-Proliferation Act of 1978 Statement on signing H.R. 8638 into Law," March 10, 1978.

- GAO, "Difficulties in Determining if Nuclear Training of Foreigners Contributes to Weapons Proliferation," report GAO ID-79-2, April 23, 1979. 
- GAO, "Three Senate Bills Introduced to Reform the Regulatory Framework for Nuclear Waste Management," Testimony before the Senate Committee on Environment and Public Works: Nuclear Regulation Subcommittee, June 14, 1978.

- [GAO1978 Barnwell Testimony] GAO, "Statement of J. Dexter Peach, Deputy Director Energy and Minerals Division; Before the Subcommittee on Energy, Nuclear Proliferation and Federal Services; Senate Committee on Governmental Affairs on Nuclear Waste Management and Spent Fuel Storage," testimony, July 25, 1978.

- GAO, "Major Unresolved Issues Preventing a Timely Resolution to Radioactive Waste Disposal," report EMD-78-94, July 13, 1978.

- [GAO-EMD-78-97] GAO, "An Evaluation of Federal Support of the Barnwell Reprocessing Plant and the Department of Energy's Spent Fuel Storage Policy," report EMD-78-97, July 20, 1978.

- U.S. Geological Survey, "Geologic Disposal of High-Level Radioactive Wastes - Earth-Science Perspectives," U.S. Geological Survey Circular 779, 1978,

- [Carter1979] Jimmy Carter, "Clinch River Breeder Reactor Statement on Action by the House Science and Technology Committee," April 27, 1979.

- GAO, "The Clinch River Breeder Reactor - Should Congress Continue to Fund it?," report EMD79-62, May 7, 1979.

- GAO, "Questions on the Future of Nuclear Power: Implications and Trade-offs," report EMD-7956 , May 21, 1979.

- GAO, "Nuclear Reactor Options to Reduce the Risk of Proliferation and to Succeed Current Light Water Reactor Technology," report EMD-79-15, May 23, 1979.

- GAO, "Nuclear Power Costs and Subsidies," report EMD-79-52, June 13, 1979.

- GAO, “The Nation's Nuclear Waste - Proposals for Organization and Siting," report EMD-7977, June 21, 1979.

- [GAO-EMD-79-82] GAO, "Federal Facilities for Storing Spent Nuclear Fuel - Are They Needed," report EMD-79-82, June 27, 1979.

- [CONAES1979] Final Report of the Committee on Nuclear and Alternative Energy Systems (CONAES), Energy in Transition, 1985-2010, December 25, 1979. This was delivered to the Secretary of Energy on this date, but copyrighted in 1980, and published in 1982.

- [INFCE1980] INFCE, "International Nuclear Fuel Cycle Evaluation," report INFCE/CP/2/9, January 1980 . (Summary and 8 working group reports)

- [Carter1980] Jimmy Carter, "Exports of Nuclear Fuels Letter to the Speaker of the House and the President of the Senate," February 7, 1980.

- GAO, "Nuclear Fuel Reprocessing and the Problems of Safeguarding against the Spread of Nuclear Weapons," report EMD-80-38, March 18, 1980.

- GAO, "The Problem of Disposing of Nuclear Low-Level Waste: Where Do We Go from Here," report EMD-80-68, March 31, 1980. 
- [NASAP1980] NASAP, "Nuclear Proliferation and Civilian Nuclear Power, Report of the Nonproliferation Alternative Systems Assessment Program," report DOE/NE-001, volumes I to IX, June 1980.

- U.S. Senate Resolution Consenting to the Ratification of the Agreement between the U.S. and the IAEA for the Application of Safeguards, July 2, 1980.

- GAO, "U.S. Breeder Reactor Program Needs Direction," report EMD-80-81, September 22, 1980.

- GAO, "U.S. Nuclear Non-Proliferation Policy: Impact on Exports and Nuclear Industry Could Not Be Determined," report GAO-ID-80-42, September 23, 1980.

- DOE, "Final Environmental Impact Statement - Management of Commercially Generated Radioactive Wastes," DOE/EIS-0046F, October 1980.

1981-1988, Reagan Administration and the $97^{\text {th }}$ to $100^{\text {th }}$ Congresses

- GAO, "The Department of Energy's Water-Cooled Breeder Program - Should It Continue?", report EMD-81-46, March 25, 1981.

- GAO, "Answers to Questions on GAO Report Entitled 'U.S. Fast Breeder Reactor Program Needs Direction," EMD-80-81, September 22, 1980," report EMD-81-83, May 4, 1981.

- GAO, "Statement of J. Dexter Peach, Director, Energy and Minerals Division, before the House Committee on Science and Technology on Termination Cost of the Clinch Breeder Reactor Plant Project," testimony, May 11, 1981.

- [GAO-EMD-81-78] GAO, "Is Spent Fuel or Waste from Reprocessed Spent Fuel Simpler to Dispose Of?," report EMD-81-78, June 12, 1981.

- GAO, "Update of Cost Information Contained in a Previous GAO Report on Specific Aspects of the Clinch River Breeder Reactor Project," report EMD-81-112, June 26, 1981.

- [Reagan1981] Ronald Reagan, "Statement Announcing a Series of Policy Initiatives on Nuclear Energy," October 8, 1981.

- GAO, "The Department of Energy Does Not Plan to Use an Abandoned Salt Mine at Lyon, Kansas, for Nuclear High-Level Waste Disposal," report EMD-82-64, March 23, 1982.

- GAO, "DOE Confident It Can Fuel the Clinch River Breeder Reactor and other Breeder Reactor Projects," report EMD-82-89, May 14, 1982.

- $\quad$ [NSDD-39] Ronald Reagan, "United States Policy on Foreign Reprocessing and Use of Plutonium Subject to U.S. Control," National Security Decision Directive 39, June 4, 1982 , portions declassified August 12, 1992.

- GAO, "The Liquid Metal Fast Breeder Reactor - Options for Deciding Future Pace and Direction," report EMD-82-79, July 12, 1982.

- GAO, "Questions Regarding Clinch River Breeder Reactor Project Funding and Costs," report EMD-82-123, September 15, 1982. 
- GAO, "Information on the Cost of Plutonium Needed to Operate the Clinch River Breeder Reactor for its 5-Year Demonstration," report EMD-82-128, September 17, 1982.

- GAO, "Interim Report on GAO's Review of the Total Cost Estimate for the Clinch River Breeder Reactor Project," report EMD-82-131, September 23, 1982.

- Convention on the Physical Protection of Nuclear Material Implementation Act of 1982 (P.L. 97-351), October 18, 1982.

- GAO, “Analysis of the Department of Energy's Clinch River Breeder Reactor Cost Estimate," report RCED-83-74, December 10, 1982.

- GAO, "Comments on the new "Nuclear Fuel Cycle Activities" Account included in House Bill 7145," report RCED-83-79, December 10, 1982.

- [NWPA 1982] Nuclear Waste Policy Act of 1982, as amended (P.L. 97-425), January 7, 1983.

- [NWeek1983] Nucleonic Week, October 27, 1983, "Special issue on the defeat of the CRBR in the Senate on October 26."

- [OTA-1982] OTA, "Managing Commercial High-Level Radioactive Waste," report, 1982. Early form of OTA-O-171 completed in 1985.

- [AEC1983] Alice L. Buck, “A History of the Atomic Energy Commission,” report DOE/ES$0003 / 1$, July 1983.

- OTA, "Nuclear Power in an Age of Uncertainty," report OTA-E-216, February 1984.

- GAO, "Return of Spent Nuclear Fuel from Foreign Research Reactors to the United States," report RCED-85-47, December 13, 1984.

- [OTA-O-171] OTA, "Managing the Nation's Commercial High-Level Radioactive Waste," report OTA-O-171, March 1985.

- J. A. Detamore, M. H. Raudenbush, R. W. Wolaver, G. A. Hastings, “TRU Waste Management Program Cost/Schedule Optimization Analysis," report DOE/JIO-004, September 30, 1984.

- David J. Rose, Learning about Energy, Plenum Press, New York, 1986.

- N. J. Trask, E. H. Roseboom, R. D. Watts, and M. S. Bedinger, "Exploration of Crystalline Rocks for Nuclear Waste Repositories: Some Strategies for Area Characterization," U.S. Department of Interior Geological Survey, open-file report 86-379, 1986.

- $\quad[\mathrm{DOE} / \mathrm{CH}-15(0)] \mathrm{DOE}$, "DRAFT Area Recommendation Report for the Crystalline Repository Project - Overview," report DOE/CH-15(0), January 1986.

- DOE, "Briefing on the Draft Area Recommendation Report, Crystalline Repository Project," slides, January-February, 1986.

- $\quad[\mathrm{DOE} / \mathrm{RW}-0074]$ DOE, “A Multiattribute Utility Analysis of Sites Nominated for Characterization for the First Radioactive-Waste Repository - A Decision-Aiding Methodology," report DOE/RW-0074, May 1986.

- $\quad$ [DOE/S-0048] DOE, "Recommendation by the Secretary of Energy of Candidate Sites for Site Characterization for the First Radioactive-Waste Repository," report DOE/S-0048, May 1986. 
- GAO, "Nuclear Waste - Issues Concerning DOE's Postponement of Second Repository Siting Activities," report RCED-86-200FS, July 30, 1986.

- [Carter 1987] Luther J. Carter, Nuclear Imperatives and Public Trust - Dealing with Radioactive Waste, Resources for the Future, Washington DC, 1987.

- DOE, "Recommendations for Management of Greater-Than-Class-C Low-Level Radioactive Waste - Report to Congress in Response to Public Law 9-240," report DOE/NE-0077, February 1987.

- Charles E. Stevenson, The EBR-II Fuel Cycle Story, American Nuclear Society, 1987.

- Ralph L. Keeney, "An Analysis of the Portfolio of Sites to Characterize for Selecting a Nuclear Repository," Risk Analysis, 7(2), 1987, pp. 195-218.

- [NRC1987] U.S. Nuclear Regulatory Commission, "for 10CFR60, "Definition of 'High-Level Radioactive Waste Advance notice of proposed rulemaking, " Federal Register, Volume 52, No. 39, February 27, 1987.

- GAO, "Nuclear Waste - DOE Should Provide More Information on Monitored Retrievable Storage," report RCED-87-92, June 1, 1987.

- [GAO-RCED-87-150] GAO, "Nuclear Nonproliferation - Department of Energy Needs Tighter Controls over Reprocessing Information," report RCED-87-150, August 17, 1987.

- GAO, "Nuclear Waste - Information on Cost Characterization Cost Estimates," report GAORCED-87-200FS, September 1987.

- [Courtfiling1988] Allied-General Nuclear Services, et al., Petitioners v. United States of America; brief for the United States in Opposition, 1988.

- Charles D. Mosher, Steven N. Calvo, David A. Bella, James L. Creighton, "Solutions to Nuclear Waste Disposal - the Question of Trust," $49^{\text {th }}$ National ASPA Conference on Frontiers in Public Service, Portland Oregon, April 19, 1988.

- B. G. Logan et al, "Summary of the U.S. Senior Committee on Environmental, Safety, and Economic Aspects of Magnetic Fusion Energy (ESECOM)," report UCRL-98634, IAEA 12 ${ }^{\text {th }}$ International Conference on Plasma Physics and Controlled Nuclear Fusion Research, Nice, France, October 12-19, 1988.

- $\quad$ OTA-BP-O-50] OTA, “An Evaluation of Options for Managing Greater-Than-Class-C LowLevel Radioactive Waste," report OTA-BP-O-50, October 1988.

\section{9-1992, Bush Administration and the $101^{\text {st }}$ to $102^{\text {nd }}$ Congresses}

- $[\mathrm{DOE} / \mathrm{RW}-0236]$ DOE, “Analysis of the Total System Life Cycle Cost for the Civilian Radioactive Waste Management Program,” report DOE/RW-0236, May 1989.

- George Bush, "Review of United States Non-Proliferation Policy," National Security Review 17, June 15, 1989, declassified on April 23, 2002.

- GAO, "Nuclear Waste: Changes Needed in DOE User-Fee Assessments to Avoid Funding Shortfall," report GAO-RCED-90-65, June 7, 1990. 
- GAO, "Nuclear Waste - Information on DOE's Interim Transuranic Waste Storage Facilities," report RCED-90-166, June 8, 1990.

- $\quad$ DOE/RW-0295SP] DOE, "Preliminary Estimates of the Total-System Cost for the Restructured Program: An Addendum to the May 1989 Analysis of the Total-system Life Cycle Cost for the Civilian Radioactive Waste Management Program," report DOE/RW-0295SP, December 1990.

- OTA," Long-Lived Legacy: Managing High-Level and Transuranic Waste at the DOE Nuclear Weapons Complex," report OTA-BP-O-83, May 27, 1991.

- George Bush, "Letter to Congressional Leaders on Nuclear Cooperation With EURATOM," March 9, 1992.

- [GAO-RCED-92-73] GAO, "Nuclear Waste - DOE's Repository Site Investigations, a Long and Difficult Task," report RCED-92-73, May 1992.

- G. H. W. Bush, "United States Nonproliferation Policy," National Security Directive 70, July 10, 1992.

- [Bush1992] G. H. W. Bush, "President's Statement," Office of the Press Secretary, July 13, 1992. Declassified on February 15, 1999. Also cited as G. H. W. Bush, "Statement on Nuclear Nonproliferation Efforts," July 13, 1992.

- [Bush1992a] White House, Office of the Press Secretary, "Non-proliferation Initiative," Fact sheet, July 13, 1992.

- [EnergyPolicyAct1992] Energy Policy Act of 1992 (P.L. 102-486), October 24, 1992.

\section{3-2000, Clinton Administration and the $103^{\text {rd }}$ to $106^{\text {th }}$ Congresses}

- [Clinton1993] William J. Clinton," Letter to Congressional Leaders on Nuclear Cooperation with EURATOM," March 9, 1993.

- [OTA-ISC-559] OTA, "Proliferation of Weapons of Mass Destruction: Assessing the Risks," report OTA-ISC-559, August 1993.

- $\quad$ PPDD-13] William J. Clinton, "Non-Proliferation and Export Control Policy," Presidential Decision Directive-13 (PDD-13), September 1993.

- [Clinton1993a] "Fact Sheet - Nonproliferation and Export Control Policy," The White House, Office of the Press Secretary, September 27, 1993.

- OTA, "Dismantling the Bomb and Managing the Nuclear Materials," report OTA-O-572, September 1993.

- GAO, "Nuclear Waste - Funds Spent to Identify a Monitored Retrievable Storage Facility Site," report RCED-93-199, September 7, 1993.

- [OTA-BP-ISC-115] OTA, "Technologies Underlying Weapons of Mass Destruction," report OTA-BP-ISC-115, December 1993.

- [RCED-94-16s] GAO, "Nuclear Science - Developing Technology to Reduce Radioactive Waste May Take Decades and Be Costly," report RCED-94-16s, December 1, 1993. 
- [NAS1994] Committee on International Security and Arms Control, Management and Disposition of Excess Weapons Plutonium, National Academy Press, Washington DC, 1994.

- $\quad$ OTA-BP-ENV-126] OTA, "Technical Options for the Advanced Liquid Metal Reactor," report OTA-BP-ENV-126, May 1994.

- OTA," Export Controls and Nonproliferation Policy," report OTA-ISS-596, May 1994.

- GAO, "Nuclear Waste - Comprehensive Review of the Disposal Program is Needed," report RCED-94-299, September 27, 1994.

- W. J. Clinton, "Proliferation of Weapons of Mass Destruction," Executive Order 12938, November 14, 1994.

- [NAS1995] Committee on International Security and Arms Control, Panel on Reactor-Related Options, Management and Disposition of Excess Plutonium: Reactor-Related Options, National Academy Press, Washington, D.C., 1995.

- [OTA-ISS-615] OTA, "Nuclear Safeguards and the International Atomic Energy Agency," report OTA-ISS-615, April 1995.

- David Shropshire, Michael Sherick, Chuck Biagi, "Waste Management Facilities Cost Information for Transuranic Waste," INEL-95/0015 (formerly EGG-WM-11274), Revision 1, June 1995.

- [Lomenick1996] T. F. Lomenick, "The Siting Record: An Account of the Programs of Federal Agencies and Events That Have Led to the Selection of a Potential Site for a Geologic Repository for High-Level Radioactive Waste," ORNL/TM-12940, March 1996.

- [GAO-RCED-96-146] GAO, "Nuclear Waste - Uncertainties About Opening Waste Isolation Pilot Plant,” report RCED-96-146, July 16, 1996.

- [Hannum1997] W. H. Hannum, D. C. Wade, H. F. Macfarlane, and R. N. Hill, "Nonproliferation and Safeguards Aspects of the IFR," Progress in Nuclear Energy, 31 (1-2), pp. 203-217, 1997.

- GAO, "Department of Energy - Plutonium Needs, Costs, and Management Programs," report RCED-97-98, April 17, 1997.

- [Aron1997] Joan Aron, Licensed to Kill? The Nuclear Regulatory Commission and the Shoreham Power Plant, 1997, specifically page 126.

- GAO, "Nuclear Nonproliferation and Safety - Uncertainties About the Implementation of U.S.Russian Plutonium Disposition Efforts," report RCED-98-46, January 14, 1998.

- [Forsberg1998] C. W. Forsberg, C. M. Hopper, J. L. Richter, H. C. Vantine, "Definition of Weapons-Usable Uranium-233," report ORNL/TM-13517, March 1998.

- GAO, "Department of Energy- Problems and Progress in Managing Plutonium," report RCED98-68, April 17, 1998.

- Paul Leventhal and Steven Dolley, "Viewpoint - The Plutonium Fallacy: An Update," The Nonproliferation Review, Spring-Summer, 1999.

- P. J. Bereolos, "Strategy for the Future Use and Disposition of Uranium-233: History, Inventories, Storage Facilities, and Potential Future Uses," report ORNL/TM-13551, June 1998. 
- [DOE/RW-0510] DOE, "Analysis of the Total System Life Cycle Cost of the Civilian Radioactive Waste Management Program,” report DOE/RW-0510, December 1998.

- [SAND99-2719J] Rob P. Rechard, "Historical Background on the Performance Assessment for the Waste Isolation Pilot Project," report SAND99-2719J, March 1999.

- [Forsberg1999a] C. W. Forsberg, "Disposition Options for Uranium-233," report ORNL/TM13553, June 1999.

- [INFCIRC/225/Rev4] IAEA, “The Physical Protection of Nuclear Material," report INFCIRC/225/Rev.4 (Corrected), June 1999.

- John Deutch et al, "Combating Proliferation of Weapons of Mass Destruction," Commission to Assess the Organization of the Federal Government to Combat the Proliferation of Weapons of Mass Destruction, July 14, 1999.

- [Forsberg1999b] C. W. Forsberg, et al, "Uses for Uranium-233: What Should be Kept for Future Needs?", report ORNL-6952, September 24, 1999.

- $\quad$ [NAS2000] Panel to Review the Spent Fuel Standard for Disposition of Excess Weapons Plutonium, The Spent-Fuel Standard for Disposition of Excess Weapon Plutonium, National Academy of Sciences, 2000.

- [DOE/CAO-00-3124] DOE, “The Waste Isolation Pilot Plant - Pioneering Nuclear Waste Disposal", report DOE/CAO-00-3124, February 2000.

- GAO, "Weapons of Mass Destruction - DOD's Actions to Combat Weapons Use Should Be More Integrated and Focused," GAO/NSIAD-00-97, May 2000.

- Report by the TOPS Task Force of the Nuclear Energy Research Advisory Committee (NERAC), "Annex: Attributes of Proliferation Resistance for Civilian Nuclear Power systems," October 2000 .

\section{1-2008, Bush Administration and the $107^{\text {th }}$ to $110^{\text {th }}$ Congresses}

- Report by the TOPS Task Force of the Nuclear Energy Research Advisory Committee (NERAC), "Technological Opportunities to Increase the Proliferation Resistance of Global Civilian Nuclear Power Systems (TOPS)," January 2001.

- [DOE/RW-0533] DOE, “Analysis of the Total System Life Cycle Cost of the Civilian Radioactive Waste Management Program," report DOE/RW-0533, May 2001.

- [NEP2001] National Energy Policy Development Group, "National Energy Policy," May 2001.

- GAO, "Nuclear Waste - Agreement among Agencies Responsible for the West Valley Site is Critically Needed," report GAO-01-314, May 11, 2001.

- GAO, "Nuclear Cleanup - DOE Should Reevaluate Waste Disposal Options Before Building New Facilities," report GAO-01-441, May 25, 2001.

- American Nuclear Society, "Nonproliferation," Position Statement 55, November 2001.

- American Nuclear Society, "Nonproliferation Background Report," background for Position Statement 55, November 2001. 
- GAO, "Nuclear Waste - Technical, Schedule, and Cost Uncertainties of the Yucca Mountain Repository Project," report GAO-02-191, December 12, 2001.

- [RDD-8] DOE, "Restricted Data Declassification Decisions 1946 to the Present (RDD-8)," January 1, 2002, http://www.fas.org/sgp/othergov/doe/rdd-7.html

- George W. Bush, "Letter to Congressional Leaders Recommending the Yucca Mountain Site for the Disposal of Spent Nuclear Fuel and Nuclear Waste," February 15, 2002.

- $\quad$ R. A. Krakowski and C. G. Bathke, "Method for Quantitative Assessment of Cost and Proliferation Risks Associated with the Civilian Nuclear Fuel Cycle as Applied to the Advanced Accelerator Applications (AAA) Program," Los Alamos National Laboratory report LA-UR-022369, April 26, 2002.

- R. Bennett, "Evaluation Criteria in the Generation IV Technology Roadmap, EC Workshop on the Nuclear Cycle System for the $21^{\text {st }}$ Century," talk at the Institute for Transuranium Elements, Karlsruhe, May 7, 2002.

- Document published by the White House, "Security Strategy of the United States of America," September 2002.

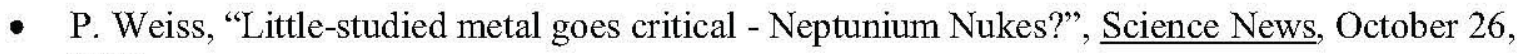
2002.

- American Nuclear Society, "Disposition of Surplus Weapons Plutonium Using Mixed Oxide Fuel," Background for Position Statement 47, November 2002.

- Document published by the White House, "National Strategy to Combat Weapons of Mass Destruction," December 2002.

- Nuclear Energy Research Advisory Committee and the Generation IV International Forum, "Generation IV Roadmap - Technology Goals for Generation IV Nuclear Energy Systems," report GIF-019-00, December 2002.

- U.S. DOE Nuclear Energy Research Advisory Committee and the Generation IV International Forum, "A Technology Roadmap for the Generation IV Nuclear Energy systems," report GIF002-00, December 2002.

- Paul Leventhal, Sharon Tanzer, Steven Dolley, Nuclear Power and the Spread of Nuclear Weapons - Can We Have One without the Other?, 2002.

- [GAO-03-593] GAO, "Nuclear Waste - Challenges to Achieving Potential Savings in DOE's High-Level Waste Cleanup Program," report GAO-03-593, June 17, 2003.

- GAO, "Spent Nuclear Fuel - Options Exist to Further Enhance Security," report GAO-03-426, July 15, 2003.

- GAO, "Energy Task Force - Process Used to Develop the National Energy Policy," report GAO03-894, August 22, 2003.

- CRS/Carl E. Behrens, "Nuclear Nonproliferation Issues," Resources, Science, and Industry Division, August 25, 2003.

- NRC, "Plutonium," fact sheet, October 2003. 
- [NuclearNews2004] Catherine Westfall, "Vision and reality: The EBR-II story," Nuclear News, February 2004, pp. 25-32.

- [Bunn2004] Matthew Bunn, "Proliferation-Resistance (and Terror-Resistance) of Nuclear Energy Systems," Managing the Atom Project, Harvard University, Lecture for "Nuclear Energy Economics and Policy Analysis", April 12, 2004, http://www.ksg.harvard.edu/bcsia/atom

- [Graham2004] Thomas Graham, Jr, Common Sense on Weapons of Mass Destruction, 2004.

- George W. Bush, “G-8 Action Plan on Nonproliferation,” June 9, 2004.

- GAO, "Nuclear Regulatory Commission - NRC Needs to Do More to Ensure that Power Plants are Effectively Controlling Spent Nuclear Fuel," report GAO-05-339, April 8, 2005.

- [GAO-05-665] GAO, "Securing U.S. Nuclear Materials - DOE Needs to Take Action to Safely Consolidate Plutonium," report GAO-05-665, July 20, 2005.

- [EnergyPolicyAct2005] Energy Policy Act of 2005 (P.L. 109-58), August 8, 2005.

- GAO, "Department of Energy - Improved Guidance, Oversight, and Planning Are Needed to Better Identify Cost-Saving Alternatives for Managing Low-Level Radioactive Waste," report GAO-06-94, October 31, 2005.

- American Nuclear Society, "Nuclear Fuel Recycling," Position Statement 45, November 2005.

- C. W. Coates, B. L. Broadhead, A. M. Krichinshy, R. W. Leggett, M. B. Emmett, and J. B. Hines, "Radiation Effects on Personnel Performance Capability and a Summary of Dose Levels for Spent Research Reactor Fuels," Oak Ridge National Laboratory document ORNL/TM-2005/261, 2005.

- Brice Smith, Insurmountable Risks - The Dangers of Using Nuclear Power to Combat Global Climate Change, A Report of the Institute for Energy and Environmental Research, RDR Books/IEER Press, 2006.

- DOE, "Technical Primer on Nuclear Power and Technology for the Global Nuclear Partnership," February 2006. (Was on DOE GNEP website at the time; actual document prepared by Dirk Gombert.)

- "National Military Strategy to Combat Weapons of Mass Destruction," February 13, 2006.

- George W. Bush, February 20, 2006, page 297 of 2006 presidential papers

- "The National Security Strategy of the United States of America", March 2006.

- DOE, "Report to Congress - Spent Nuclear Fuel Recycling Program Plan," May 2006.

- George W. Bush, May 24, 2006, page 1007 of 2006 presidential papers

- Proliferation Resistance and Physical Protection Evaluation Methodology Expert Group, "Evaluation Methodology for Proliferation Resistance and Physical Protection of Generation IV Nuclear Energy Systems," report GIF/PRPPWG/2006/005, Revision 5, November 30, 2006.

- United States Additional Protocol Implementation Act (P.L. 109-401), December 18, 2006. 
- William S. Charlton, et al, "Proliferation Resistance Assessment Methodology for Nuclear Fuel Cycles," Nuclear Technology, 157, pp. 143-156, February 2007.

- GAO, "Low-Level Radioactive Waste Management - Approaches Used by Foreign Countries May Provide Useful Lessons for Managing U.S. Radioactive Waste," report GAO-07-221, March 21, 2007.

- G. Kessler, "Plutonium Denaturing by Pu238," Nuclear Science and Engineering, 115, pp. 53-73, 2007.

- National Commission on Energy Policy, "Energy Policy Recommendations to the President and the $110^{\text {th }}$ Congress," April 2007.

- GAO, "Nuclear Waste - Plans for Addressing Most Buried Transuranic Wastes Are Not Final, and Preliminary Cost Estimates Will Likely Increase," report GAO-07-761, June 22, 2007.

- GNEP Technical Integration Office, "Global Nuclear Energy Partnership Technology Development Plan,” GNEP-TECH-TR-PP-2007-00020, Rev 0, July 25, 2007.

- DOE, "Department of Energy to Award \$16 Million for GNEP Studies," July 30, 2007.

- V. D. Cleary, et al, "Strengthening the Foundations of Proliferation Assessment Tools," SAND2007-6158, September 2007.

- [CRS2007] CRS, "Managing the Nuclear Fuel cycle: Policy Implications of Expanding Global Access to Nuclear Power," report RL34234, November 1, 2007.

- [Koch2008] Leonard J. Koch, EBR-II, Experimental Breeder Reactor-II - An Integrated Experimental Fast Reactor Nuclear Power Station, American Nuclear Society, 2008.

- [DOE2008] U.S. DOE, “Space Radioisotope Power Systems Safety,” January 2008.

- Lara Pierpoint, "Analyzing the Proliferation Resistance of Advanced Nuclear Fuel cycles: In Search of an Assessment Methodology for Use in Fuel Cycle Simulations," MIT thesis, February 2008.

- [CRS2008] Anthony Andrews, "Nuclear Fuel Reprocessing: U.S. Policy Development," Congressional Research Service report RS22542, November 29, 2006; updated March 27, 2008.

- [GAO-08-483] GAO, "Global Nuclear Energy Partnership - DOE Should Reassess Its Approach to Designing and Building Spent Nuclear Fuel Recycling Facilities," report GAO-08-483, April $22,2008$.

- [DOE/RW-0591] DOE, "Analysis of the Total System Life Cycle Cost of the Civilian Radioactive Waste Management Program, Fiscal Year 2007," report DOE/RW-0591, July 2008.

- IAEA, “Spent Fuel Reprocessing Options,” report IAEA-TECDOC-1587, August 2008.

- DOE, "The Report to the President and the Congress by the Secretary of Energy on the Need for a Second Repository," report DOE/RW-0595, December 2008.

2009-present, Obama Administration and the $111^{\text {st }}$ to $112^{\text {th }}$ Congresses

- Overview of United States of America's National Security Strategy 2009: Counterterrorism Policy Recommendations and Implications, Henry M. Jackson School of International Studies, 
Task Force 2009, 2009. (Because the document refers to mid-2009 in the future tense, I assume the document was completed in early 2009.)

- [Obama2009] B. H. Obama, "Remarks by President Barack Obama," Hradcany Square, Prague, Czech Republic, Office of the Press Secretary, April 5, 2009.

- [NEInternational, 4/15/2009] DOE Deputy Press Secretary Jen Stutsman, statement, April 15, 2009, quoted in Nuclear Engineering International magazine version):

http://www.neimagazine.com/story.asp?storyCode $=2052719$

- Dale Lancaster, Charles Rombough, Francis Alcorn, Thomas P. McLaughlin, "Critical Safety Issues Associated with Uranium Enriched Up to Ten Weight Percent," Advances in Nuclear Fuel Management IV (ANFM 2009), Hilton Head Island, South Carolina, USA, April 12-15, 2009.

- Ken-ichi Yoshioka, Shouichi Watanabe, Ishi Mitsuhashi, Satoshi Gunji, Mitsuaki Yamaoka, Kouji Hiraiwa, A Minimal-Content Gadolinia in Above-5wt\% Enrichment Fuel for Criticality Safety in Next-Generation LWR, Advances in Nuclear Fuel Management IV (ANFM 2009), Hilton Head Island, South Carolina, USA, April 12-15, 2009.

- Richard Royce Madison Metcalf, "New Tool for Proliferation Resistance Evaluation Applied to Uranium and Thorium Fueled Fast Reactor Fuel Cycles," Texas A\&M thesis, May 2009.

- [SECY-09-0082] Michael F. Weber, Director, Office of Nuclear Material Safety and Safeguards, Nuclear Regulatory Commission, "Update on Reprocessing Regulatory Framework-Summary of Gap Analysis," report SECY-09-0082, May 28, 2009.

- NRC, "Fact Sheet on Uranium Enrichment," May 2009, http://www.nrc.gov/reading-rm/doccollections/fact-sheets/enrichment.html

- [DOE2009] DOE, "Notice of Cancellation of the Global Nuclear Energy Partnership (GNEP) Programmatic Environmental Impact Statement (PEIS)," Federal Register, volume 74, number 123, June 29, 2009, pp. 31017-31018.

- R.Bar, L-Y Cheng, J. Phillops, J. Pilat, G. Rochau, I. Therios, R. Wigeland, E. Wonder, M. Zentner, "Proliferation Risk Reduction Study of Alternative Spent Fuel Processing," report BNL90264-2009-CP, Institute of Material Management (INMM) $50^{\text {th }}$ Annual Meeting, Tucson, Arizona, July 12-16, 2009.

- Barack Obama," L'Aquila Statement on Non-Proliferation," July 8, 2009.

- [DOE410] DOE, Management of Nuclear Materials, DOE order 410.2, August 17, 2009.

- Matthew Bunn and Martin B. Malin, "Enabling a Nuclear Revival-And Managing Its Risks," Innovations, Fall 2009, pp. 173-191.

- Charles G. Bathke, Bartley B. Ebbinghaus, Brad W. Sleaford, Richard K. Wallace, Brian A. Collins, Kevin R. Hase, Gordon D. Jarvinen, Keith S. Bradley, John R. Ireland, M. W. Johnson, Andrew W. Prichard, and Brian W. Smith, "The Attractiveness of Materials in Advanced Nuclear Fuel Cycles for Various Proliferation and Theft Scenarios," Proceedings of Global 2009, Paris, France, September 6-11, 2009, also available as Los Alamos National Laboratory report LA-UR09-02466.

- GAO, "Nuclear Waste Management - Key Attributes, Challenges, and Costs for the Yucca Mountain Repository and Two Potential Alternatives," report GAO-10-48, November 4, 2009. 
- "National Security Strategy," May 2010.

- [NRC2010] NRC, "Final update of the Commission's Waste Confidence Decision," September 15,2010 . This is the date the decision was announced. It was published in the Federal Register, vol 75, No. 246, December 23, 2010, at page 81037.

- Arjun Makhijani, "The Mythology and Messy Reality of Nuclear Fuel Reprocessing," Institute for Energy and Environmental Research, April 8, 2010.

- [Bathke2009] Charles G. Bathke, Brad W. Sleaford, Bartley B. Ebbinghaus, Brian A. Collins, Richard K. Wallace, Kevin R. Hase, Keith S. Bradley, Andrew W. Prichard, and Brian W. Smith, "An Assessment of the Attractiveness of Material Associated with Thorium/Uranium and Uranium Closed Fuel Cycles from a Safeguards Perspective," Institute of Nuclear Materials Management (INMM) 51sth Annual Meeting, Baltimore, MD, July 11-15, 2010, also available as Los Alamos National Laboratory report LA-UR-10-03899.

- [SAND2010-6335] Rob P. Rechard, Tom Cotton, Hank C. Jenkins-Smith, Mark Nutt, Joe Carter, Frank Perry, Ruth F. Weiner, James A. Blink, "End of FY10 Report - Used Fuel Disposition Technical Bases and Lessons Learned - Legal and Regulatory Framework for High-Level Waste Disposition in the United States," report SAND2010-6335, September 2010.

- [FCRD-SYSE-2011-000003, Rev 0] "Process and Evaluation Criteria for Initial Screening of Fuel Cycle Options", FCRD-SYSE-2011-000003, Rev 0, October 25, 2010,

- American Nuclear Society, "Report of the American Nuclear Society President's Special Committee on Used Nuclear Fuel Management Options," January 30, 2011.

- [FCRD-SYSE-2011-000040, Rev. 0] S. D. Sevougian et al, "Initial Screening of Fuel Cycle Options," FCRD-SYSE-2011-000040, Rev. 0, March 11, 2011.

- World Nuclear Organization, "Research Reactors," Updated March 2011, http://worldnuclear.org/info/inf61.html

- GAO, "Commercial Nuclear Waste - Effects of a Termination of the Yucca Mountain Repository Program and Lessons Learned," report GAO-11-229, April 4, 2011.

- Mark Holt/CRS, "Civilian Nuclear Waste Disposal," Congressional Research Service report RL33461, August 30, 2011.

- [Clayton2011] Daniel J. Clayton, Geoffrey A. Freeze, Teklu Hadgu, Ernest Hardin, Joon Lee, Jeralyn L. Prouty, Ralph Rogers (SNL), W. Mark Nutt (ANL), Jens T. Birkholzer, Hui-Hai Liu, Liange Zheng (LBNL), Shaoping Chu (LANL), "Generic Disposal System Modeling - Fiscal Year 2011 Progress Report," Fuel Cycle R\&D program report FCRD-USED-2011-000184, 2011.

- GAO, "Nuclear Nonproliferation - U.S. Agencies have Limited Ability to Account for, Monitor, and Evaluate the Security of U.S. Nuclear Material Overseas," report GAO-11-920, September 8, 2011.

- GAO, "Yucca Mountain - Information on Alternative Uses of the Site and Related Challenges," report GAO-11-847, September 16, 2011.

- GAO, "Nuclear Fuel Cycle Options - DOE Needs to Enhance Planning for Technology Assessment and Collaboration with Industry and Other Countries," report GAO-12-70, October 17, 2011. 
- DOE, "Reduced Enrichment for Research and Test Reactors," website, http://www.rertr.anl.gov/, Accessed October 2011

- American Institute of Physics e-newsletter, "Senate Passes Medical Isotope Production Bill," Number 142, November 30, 2011.

- "Charter for the Evaluation and Screening of Fuel Cycle Options," December 15, 2011. 


\section{TEXT EXTRACTED FROM REFERENCES}

This chapter contains extracts from some of the references consulted and listed in Chapter 3.

In this Chapter, explanations and observations by the current author are in purple italics. All other text is verbatim.

There are four sections to this chapter, as follows:

- The bulk of the documents are in chronological order.

- Laws and Congressional ratifications are in section 4.2; these are often amended later so that placing them in the timeline can sometimes be misleading. For example, the Nuclear Waste Policy Act of 1982 was significantly modified in 1987 so that reading its text, as amended (which is what matters legally today) in 1982 in a timeline is misleading.

- NRC regulations, which are also often changed over time

- IAEA documents

\subsection{Historical Documents Establishing Timeline}

Except for RDD-8, which appears first in this section, the other documents in this section are listed in chronological order.

\subsubsection{Restricted Data Declassification Decisions 1946 to the Present (RDD-8), January 1, 2002, http://www.fas.org/sgp/othergov/doe/rdd-7.html.}

The headings in bold below are from the original document. The parentheses below are in the original documents; they denote the year and sequence of a declassified fact, e.g., 92-5 means the $5^{\text {th }}$ declassification in 1992.

\section{Neptunium}

5 The mere fact that spent nuclear fuels are "blended up" and recycled through Hanford in order to increase $\mathrm{Np} 237$ production. $(62-1)$

6 The fact that $\mathrm{Np} 237$ can be used for a nuclear explosive device. (92-5)

7 The fact that the Department of Energy requires all Government-owned Np237 to be treated as a special nuclear material.(92-5)

8 The fact that the United States has non-proliferation concerns about Np237.(92-5)

\section{Plutonium}

23 Revealing the general fact of existence of nuclear weapons which contain only Pu239.(67-2)

25 The fact that reactor grade plutonium can be used to make nuclear weapons.(67-10)

26 The mere fact that high irradiation level reactor-grade plutonium can be used to make nuclear weapons.(67-10)

29 The fact that a nuclear test was conducted using reactor grade plutonium and that is successfully produced a nuclear yield.(77-4) DOE announced on June 27, 1994, that the event occurred in 1962. 
33. Special nuclear materials masses: That about $6 \mathrm{~kg}$ plutonium is enough hypothetically to make one nuclear explosive device.(93-2)

33a. Hypothetically, a mass of 4 kilograms of plutonium or uranium-233 is sufficient for one nuclear explosive device.(94-1)

V.2.b.(1) Mere fact that Pu239 alone was used in the Trinity, Nagasaki, and Crossroads series.(65-6)

\subsubsection{Atomic Bombing of Hiroshima Announcement, Harry S. Truman, 1945.}

Found at http://www.h-net.org/ hst203/documents/TRUMAN1.html

Citation: Landmark Document in American History; Public Papers of the Presidents (Harry S. Truman, 1946, p. 197-200)

Statement issued by U.S. President Harry S. Truman on August 6, 1945, announcing that the United States had dropped a single atomic bomb on the Japanese city of Hiroshima earlier that day. Truman described the bomb as a revolutionary new force for destruction, harnessing the basic power of the universe and having more force than 20,000 tons of TNT. More than 70,000 people were killed. The U.S. president warned that if the Japanese continued to refuse to surrender unconditionally, "they may expect a rain of ruin from the air, the like of which has never been seen on this earth."

On August 9, the United States dropped a second atomic bomb, on Nagasaki.

\subsubsection{Henry DeWolf Symth, Atomic Energy for Military Purposes, "The Official Report on the Development of the Atomic Bomb under the Auspices of the United States Government," 1940-1945, August 12, 1945.}

http://www.atomicarchive.com/Docs/SmythReport/index.shtml

This was the vehicle for the federal government to reveal a lot about the Manhattan project to the public. It mentions Einstein's 1905 paper and Einstein's 1939 letter to Roosevelt.

\subsubsection{United States Atomic Energy Commission, "Civilian Nuclear Power - a Report to the President - 1962," Washington DC, November 20,1962, http://energyfromthorium.com/msrp/cnp1962/}

No mention of transuranics other than plutonium.

The emphasis on uranium and plutonium is solely energy supply. No linkage or mention of reprocessing in the context of waste management (either as a way to reduce burdens or as a source of additional wastes).

This AEC report is in response to this letter to the AEC from President Kennedy, quoted here verbatim.

Letter to the Chairman, Atomic Energy Commission, on the Development of Civilian Nuclear Power. March 20,1962 [Released March 20, 1962. Dated March 17, 1962]

Dear Mr. Chairman:

The development of civilian nuclear power involves both national and international interests of the United States. At this time it is particularly important that our domestic needs and prospects for atomic 
power be thoroughly understood by both the Government and the growing atomic industry of this country which is participating significantly in the development of nuclear technology. Specifically we must extend our national energy resources base in order to promote our nation's economic growth.

Accordingly, the Atomic Energy Commission should take a new and hard look at the role of nuclear power in our economy in cooperation with the Department of the Interior, the Federal Power Commission, other appropriate agencies, and private industry. Your study should identify the objectives, scope, and content of a nuclear power development program in the light of the nation's prospective energy needs and resources and advances in alternate means for power generation.

It should recommend appropriate steps to assure the proper timing of development and construction of nuclear power projects, including the construction of necessary prototypes. There should, of course, be a continuation of the present fruitful cooperation between Government and industry - public utilities, private utilities and equipment manufacturers.

Upon completion of this study of domestic needs and resources, there should also be an evaluation of the extent to which our nuclear power program will further our international objectives in the peaceful uses of atomic energy.

The nuclear powerplants scheduled to come into operation this year, together with those already in operation, should provide a wealth of engineering experience permitting realistic forecasts of the future of economically competitive nuclear power in this country.

As you are aware, two major related studies are now or will soon be under way. The study being conducted at my request by the National Academy of Sciences on the development and preservation of all our national resources will focus on the nation's longer-term energy needs and utilization of fuel resources. The other study to be launched soon by the Federal Power Commission will determine the long range power requirements of the nation and will suggest the broad outline of possible programs of growth for all electric power companies - both private and public - to meet the great increase in power needs. Your study should be appropriately related to these investigations.

The extensive and vigorous atomic power development programs currently being undertaken by the Commission should, of course, be continued and, where appropriate, strengthened during the period of your study. I urge that your review be undertaken without delay and would hope that you could submit a report by September 1, 1962.

Sincerely, JOHN F. KENNEDY

\section{Quotes from the AEC report}

The program should include: (1) early construction of plants of the presently most competitive reactor types; (2) development, construction and demonstration of advanced converters to improve the economics and the use of nuclear fuels; (3) intensive development and, later, demonstration of breeder reactors to fill the long-range needs of utilizing fertile as well as fissile fuels.

\section{Breeders}

In our discussion of nuclear resources we have seen that the energy contained in fissionable uranium-235 in the supplies of relatively low-cost ores is so limited that the fertile materials must be extensively exploited if nuclear energy is to be of widespread and lasting benefit. Hence, there is a fairly near-term, though not immediate, need for reactors that produce more fissionable material than they consume. 
Breeder reactors are of two general kinds, "fast breeders", utilizing the uranium-plutonium cycle and "thermal" breeders utilizing the thorium-U-233 cycle. Unfortunately, none of these are nearly so well developed at this time, either technically or economically, as the converters are.

The nuclear properties of uranium-235 and plutonium are such that more neutrons are released from fissions brought about by fast than by slow neutrons. Indeed, the difference is so great as to make breeding feasible in fast, but not in thermal reactors utilizing these materials. Unfortunately, there are combined technical and economic difficulties in fast reactors. Good breeding gains obviously require that the fuel material be not overly diluted with other substances that absorb or moderate the neutrons. $\dagger$ Hence, to avoid large and expensive fuel inventories, the power that they generate must be concentrated in small volumes. This gives rise to engineering and safety problems of removing heat at the necessary rate. Furthermore, it is difficult to develop concentrated fuels that will endure until a substantial fraction of the fuel has been consumed and hence minimize expensive refabrication of the fuel elements. So far these factors have combined to make fast breeders quite expensive. Fortunately, there are promising developments for greatly improved fuels. These include "ceramic" fuels such as uranium- and plutoniumoxides and carbides. In the farther future is the possibility of utilizing molten plutonium.

Most effort in fast breeders has involved utilizing molten sodium or sodium-potassium alloys as the coolant. This has required a complex and expensive new technology, including development of pumps, heat exchangers, and the like, of compatible materials. Fortunately, development work for the sodiumgraphite reactor has also contributed to this technology.

In the thorium-uranium-233 cycle, the situation is quite different. U-233 emits more neutrons in thermal fission than does U-235; on the other hand, it is only slightly better in fast fission than in slow. Hence, thermal breeders offer greatest promise, minimizing as they do the power density and fuel endurability requirements. However, thermal breeders have a different complication in that fission products act as strong absorbers of slow neutrons, requiring that these products not accumulate too much. Among the most promising solutions of this difficulty is to use the fuel in fluid form, thus permitting continuous extraction and reprocessing to remove the fission products. Various fluid fuels have been studied for this purpose. The currently most promising approach is the use of fused uranium salts which can be circulated, both for reprocessing purposes and for heat transport. This technology is, however, in a fairly early stage.

\section{Statement of Objectives}

Taking account of the need for nuclear power, the responsibilities of the Atomic Energy Commission, the state of nuclear power technology, its future possibilities, and the existence and potentialities of the nuclear industry, we have arrived at the following statement of objectives:

The overall objective of the Commission's nuclear power program should be to foster and support the growing use of nuclear energy and, importantly, to guide the program in such directions as to make possible the exploitation of the vast energy resources latent in the fertile materials, uranium-238 and thorium.

More specific objectives may be summarized as follows:

1. The demonstration of economic nuclear power by assuring the construction of plants incorporating the presently most-competitive reactor types;

2. The early establishment of a self-sufficient and growing nuclear power industry that will assume an increasing share of the development costs;

3. The development of improved converter and, later, breeder reactors to convert the fertile isotopes to fissionable ones, thus making available the full potential of the nuclear fuels. 
4. The maintenance of U. S. technological leadership in the world by means of a vigorous domestic nuclear power program and appropriate cooperation with, and assistance to, our friends abroad.

The role of the Commission in achieving these objectives must be one of positive and vigorous leadership both to achieve the technical goals and to assure growing participation by the equipment and utility industry as nuclear power becomes economic in increasing areas of this country and the world at large."

The Future Program

We have concluded earlier that a logical progression to achieve the objectives of the nuclear power program will involve three overlapping phases: (1) The immediate utilization of reactor types that are, or can readily be made, economically competitive with conventional power installations; (2) a transitional stage, characterized by improving economics through higher temperatures, longer fuel life and other technical improvements and by the introduction of improved converter types with better economics and higher conversion ratios; (3) a long-range phase utilizing breeders that multiply by a large factor the energy extracted from the nuclear fuel, hence freeing the technology of any marked dependence on the cost of raw materials and opening up vast energy reserves; converters burning U-235 will continue to be essential until such a time as breeders produce enough new fissionable material to fuel the necessary additional reactors; in the interval, conversion ratios will become increasingly important as the costs of raw materials rise.

\subsubsection{Richard Nixon, "Special Message to the Congress on Energy Resources," June 4, 1971.}

My program includes the following elements:

To Facilitate Research and Development for Clean Energy:

-- A commitment to complete the successful demonstration of the liquid metal fast breeder reactor by 1980 .

-- More than twice as much Federal support for sulfur oxide control demonstration projects in Fiscal Year 1972.

-- An expanded program to convert coal into a clean gaseous fuel.

-- Support for a variety of other energy research projects in fields such as fusion power, magnetohydrodynamic power cycles, and underground electric transmission.

\section{b. Nuclear Breeder Reactor}

Our best hope today for meeting the Nation's growing demand for economical clean energy lies with the fast breeder reactor. Because of its highly efficient use of nuclear fuel, the breeder reactor could extend the life of our natural uranium fuel supply from decades to centuries, with far less impact on the environment than the power plants which are operating today.

For several years, the Atomic Energy Commission has placed the highest priority on developing the liquid metal fast breeder. Now this project is ready to move out of the laboratory and into the demonstration phase with a commercial size plant. But there still are major technical and financial obstacles to the construction of a demonstration plant of some 300 to 500 megawatts. I am therefore requesting an additional \$27 million in Fiscal Year 1972 for the Atomic Energy Commission's liquid metal fast breeder reactor program--and for related technological and safety programs--so that the necessary engineering groundwork for demonstration plants can soon be laid. 
What about the environmental impact of such plants? It is reassuring to know that the releases of radioactivity from current nuclear reactors are well within the national safety standards. Nevertheless, we will make every effort to see that these new breeder reactors emit even less radioactivity to the environment than the commercial light water reactors which are now in use.

I am therefore directing the Atomic Energy Commission to ensure that the new breeder plants be designed in a way which inherently prevents discharge to the environment from the plant's radioactive effluent systems. The Atomic Energy Commission should also take advantage of the increased efficiency of these breeder plants, designing them to minimize waste heat discharges. Thermal pollution from nuclear power plants can be materially reduced in the more efficient breeder reactors.

We have very high hopes that the breeder reactor will soon become a key element in the national fight against air and water pollution. In order further to inform the interested agencies and the public about the opportunities in this area, I have requested the early preparation and review by all appropriate agencies of a draft environmental impact statement for the breeder demonstration plant in accordance with Section 102 of the National Environmental Policy Act. This procedure will ensure compliance with all environmental quality standards before plant construction begins.

In a related area, it is also pertinent to observe that the safety record of civilian power reactors in this country is extraordinary in the history of technological advances. For more than a quarter century-since the first nuclear chain reaction took place--no member of the public has been injured by the failure of a reactor or by an accidental release of radioactivity. I am confident that this record can be maintained. The Atomic Energy Commission is giving top priority to safety considerations in the basic design of the breeder reactor and this design will also be subject to a thorough review by the independent Advisory Committee on Reactor Safeguards, which will publish the results of its investigation.

I believe it important to the Nation that the commercial demonstration of a breeder reactor be completed by 1980 . To help achieve that goal, I am requesting an additional $\$ 50$ million in Federal funds for the demonstration plant. We expect industry--the utilities and manufacturers-to contribute the major share of the plant's total cost, since they have a large and obvious stake in this new technology. But we also recognize that only if government and industry work closely together can we maximize our progress in this vital field and thus introduce a new era in the production of energy for the people of our land.

\subsubsection{GAO, "The Liquid Metal Fast Breeder Reactor: Promises and Uncertainties," report GAO-OSP-76-1, July 1975.}

This report was the sixth in an annual series summarizing how the GAO viewed the LMFBR program. Interestingly, this report indicates three controversies, none of which is proliferation.

Because LMFBRs will breed from natural uranium more nuclear fuel than they consume, they offer the promise of substantially extending the life of the Nation's uranium resources and are a key future option for generation of central station electric power.

The LMFBR is controversial because

-- it is the most likely vehicle by which nuclear fission may become an assured energy source through the 21 st century and beyond,

-- key uncertainties persist with respect to the need for and the economics and safety of LMFBRs, and

-- research and development to resolve the uncertainties is an expensive, and often time consuming, matter. 
Some uncertainties and problems are unique to the LMFBR. However, problems of safeguarding nuclear materials and problems of radioactive waste disposal are already present with existing reactors.

Thus, the LMFBR is intimately intertwined with the benefits and risks to society from continued use of nuclear fission in any form.

\subsubsection{GAO, "Assessment of U.S. and International Controls over the Peaceful Uses of Nuclear Energy," report ID-76-60, September 14, 1976.}

Although the United States has supplied about 70 percent of the world's nuclear reactors and much of the related fuel and technology, nations seeking nuclear assistance can now turn to other suppliers, including the Soviet Union, France, West Germany, Sweden, Canada, and the United Kingdom. Therefore, halting U.S. exports would not eliminate the escalating risks and could cost the United States its ability to influence international nuclear policies.

As the world's leading nuclear exporter, the United States has a responsibility to exercise leadership in deterring other nations from developing nuclear explosives and should exercise whatever leverage it has to achieve its non-proliferation objectives. Continued dominance in nuclear sales, using the strongest practical precautions, will give the United States the best opportunity to continue to promote global nonproliferation policies. However, the expanding market will be shared by a growing number of supplier countries, which will make multilateral control efforts absolutely necessary.

In view of the seriousness of the issue, GAO reviewed U.S. and international controls over the peaceful uses of nuclear energy to determine their adequacy for deterring nuclear weapons proliferation and found that:

-- The United States has sought improvements in international safeguards and physical security of nuclear materials and equipment, but much more must be done. (See chs. 3, 4, and 6.)

-- Despite U.S. efforts, certain countries have not ratified the 'Treaty on the Non-Proliferation of Nuclear Weapons which would preclude them from operating unsafeguarded facilities and from developing nuclear explosives. (see p. 77.)

-- Recent nuclear suppliers' efforts designed to achieve parallel nuclear export policies have been made without being subjected to intense congressional or public scrutiny. (See p. 75.)

-- International safeguards are designed only to detect diversions of nuclear material on a national level, and it is assumed that nations will protect nuclear material from terrorist or subnational groups. The principle of such safeguards is that the risk of early detection and unmasking in the world community will deter a would-be diverter. (See p. 19.)

-- U.S. and International Atomic Energy Agency officials generally conceded that a country could circumvent safeguards if it was willing to assume the risk of detection, incur the expense, and take the trouble to do so. (See p. 40.)

-- The United States has accepted safeguards applied by the International Atomic Energy Agency and the European Atomic Energy Community as satisfying U.S. requirements but in GAO's opinion has not received sufficient information to determine how effective these safeguards are. (See pp. 38 to 44.)

-- Should a country divert nuclear material from peaceful purposes or knowingly supply material or technology to another country for developing nuclear weapons, the only actions the International Atomic Energy Agency can currently take are (1) notification to member countries and the United Nations, (2) suspension of Agency membership rights and privileges, and (3) recall of Agency- 
sponsored material and technical assistance. It is not clear, however, how Agency sponsored material would be retrieved if a nation were unwilling to return it. (See p. 27.)

-- Based on limited first-hand observations, GAO believes the United States may be relying on international safeguards inspections that are not adequately carried out. (See p. 41.)

-- The United States has authorized the distribution of substantial amounts of nuclear materials and equipment to certain countries through international organizations without reserving U.S. safeguards and inspection rights as a fallback to international safeguards. (See p. 14.)

-- The U.S. peaceful nuclear export licensing and regulatory control program is fragmented among the Nuclear Regulatory Commission, the Energy Research and Development Administration, and the Department of Commerce. (See p. 46.)

\subsubsection{Memorandum of Conversation - President Ford; Louis deGuiringaud, Minister of Foreign Affairs of France; Dr. Henry A. Kissinger, Secretary of State Brent Scowcroft, Assistant to the President for National Security Affairs; Amb. Jacques Kosciusko-Morizet, Ambassador of France, October 1, 1976.}

This memo notes French-US discussions on proliferation. The French promise not to sign any agreements with Iran on reprocessing. (Note the date; this was Iran under the Shah. An Iran already building nuclear capability and the current authors knows from personal experience the controversial MIT-Iran agreement on training nuclear engineers for them in this time period.) For example, French Minister deGuiringaud states ...

We are going to Iran and could do it after that. We will not sign any commitments with them on reprocessing. We will tell them that we are reviewing policy. Maybe we will sign for two reactors, but not anything on reprocessing. We will assure them we will reprocess in France the fuel from the plants we give them.

They were trying to put pressure on other nations to follow similar approach, explicitly including the Germans. Ford's address later that month on reprocessing should be viewed from this perspective.

\subsubsection{Gerald R. Ford, Radio Address on Peace / Statement on Nuclear Policy, Presidential Documents, vol. 12, no. 44, pp. 1626-1627, October 28, 1976.}

In 1974, soon after I assumed office, I became concerned that some nuclear supplier countries, in order to achieve competitive advantage, were prepared to offer nuclear exports under conditions less rigorous that we believe prudent. In the fall of that year, at the United Nations General Assembly, the United States proposed that nonproliferation measures be strengthened materially. I also expressed my concern directly to my counterparts in key supplier and recipient nations. I directed the Secretary of State to emphasize multilateral action to limit this dangerous form of competition.

At the U.S. initiative, the first meeting of major nuclear suppliers was convened in London in April 1975. At series of meetings and intensive bilateral consultations followed. As a result of these meetings, we have significantly raised international standards through progressive new guidelines to govern nuclear exports. These involve both improved safeguards and controls to prevent diversion of nuclear materials and to guard against the misuse of nuclear technology and physical protection against theft and sabotage. The United States has adopted these guidelines as policy for nuclear exports.

In addition, we have acted to deal with the special dangers associated with plutonium. 
-- We have prohibited export of reprocessing and other nuclear technologies that could contribute to proliferation.

-- We have firmly opposed reprocessing in Korea and Taiwan. We welcome the decisions of those nations to forego such activities. We will continue to discourage national reprocessing in other locations of particular concern.

-- We negotiated agreements for cooperation with Egypt and Israel which contain the strictest reprocessing provisions and other nuclear controls ever included in the 20-year history of our nuclear cooperation program.

-- In addition, the United States recently completed negotiations to place its civil nuclear facilities under the safeguards of the International Atomic Energy Agency--and the IAEA has approved a proposed agreement for this purpose.

\section{NEW INITIATIVES}

Last summer, I directed that a thorough review be undertaken of all our nuclear policies and options to determine what further steps were needed. I have considered carefully the results of that review, held discussions with congressional leaders, and benefited from consultations with leaders of other nations. I have decided that new steps are needed, building upon the progress of the past 2 years. Today, I am announcing a number of actions and proposals aimed at:

-- strengthening the commitment of the nations of the world to the goal of nonproliferation and building an effective system of international controls to prevent proliferation;

-- changing and strengthening U.S. domestic nuclear policies and programs to support our nonproliferation goals; and

-- establishing, by these actions, a sound foundation for the continued and increased use of nuclear energy in the U.S. and in the world in a safe and economic manner.

The task we face calls for an international cooperative venture of unprecedented dimensions. The U.S. is prepared to work with all other nations.

\section{PRINCIPAL POLICY DECISIONS}

I have concluded that the reprocessing and recycling of plutonium should not proceed unless there is sound reason to conclude that the world community can effectively overcome the associated risks of proliferation. I believe that avoidance of proliferation must take precedence over economic interests. I have also concluded that the United States and other nations can and should increase their use of nuclear power for peaceful purposes even if reprocessing and recycling of plutonium are found to be unacceptable.

Vigorous action is required domestically and internationally to make these judgments effective.

-- I have decided that the United States should greatly accelerate its diplomatic initiatives in conjunction with nuclear supplier and consumer nations to control the spread of plutonium and technologies for separating plutonium.

Effective nonproliferation measures will require the participation and support of nuclear suppliers and consumers. There must be coordination in restraints so that an effective nonproliferation system is achieved, and there must be cooperation in assuring reliable fuel supplies so that peaceful energy needs are met. 
-- I have decided that the United States should no longer regard reprocessing of used nuclear fuel to produce plutonium as a necessary and inevitable step in the nuclear fuel cycle, and that we should pursue reprocessing and recycling in the future only if they are found to be consistent with our international objectives.

We must insure that our domestic policies and programs are compatible with our international position on reprocessing and that we work closely with our nations in evaluation nuclear fuel reprocessing.

We must ensure that our domestic policies and programs are compatible with our international position on reprocessing and that we work closely with other nations in evaluating nuclear fuel reprocessing.

-- The steps I am announcing today will assure that the necessity increase in our use of nuclear energy will be carried on with safety and without aggravating the danger of proliferation.

Even with strong efforts to conserve, we will have increasing demands for energy for a growing American economy. To satisfy these needs, we must rely on increased use of both nuclear energy and coal until more acceptable alternatives are developed. We will continue pushing ahead with work on all promising alternatives such as solar energy but now we must count on the technology that works. We cannot expect a major contribution to our energy supply from alternative technologies until late in this century.

To implement my overall policy decisions, I have decided on a number of policies that are necessary and appropriate to meet our nonproliferation and energy objectives.

-- First, our domestic policies must be changed to conform to my decision on deferral of the commercialization of chemical reprocessing of nuclear fuel which results in the separation of plutonium.

-- Second, I call upon all nations to join us in exercising maximum restraint in the transfer of reprocessing and enrichment technology and facilities by avoiding such sensitive exports or commitments for a period of at least 3 years.

-- Third, new cooperative steps are needed to help assure that all nations have an adequate and reliable supply of energy for their needs. I believe, most importantly, that nuclear supplier nations have a special obligation to assure that customer nations have an adequate supply of fuel for their nuclear power plants, if those customer nations forego the acquisition of reprocessing and uranium enrichment capabilities and accept effective proliferation controls.

-- Fourth, the U.S. must maintain its role as a major and reliable world supplier of nuclear reactors and fuel for peaceful purposes. Our strong position as a supplier has provided the principal basis for our influence and leadership in worldwide nonproliferation efforts. A strong position will be equally important in the future. While reaffirming this Nation's intent to be a reliable supplier, the U.S. seeks no competitive advantage by virtue of the worldwide system of effective nonproliferation controls that I am calling for today.

-- Fifth, new efforts must be made to urge all nations to join in a full-scale international cooperative effort--which I shall outline in detail--to develop a system of effective controls to prevent proliferation.

-- Sixth, the U.S. must take new steps with respect to its own exports to control proliferation, while seeking to improve multilateral guidelines. 
-- Seventh, the U.S. must undertake a program to evaluate reprocessing in support of the international policies I have adopted.

-- Finally, I have concluded that new steps are needed to assure that we have in place when needed, both in the U.S. and around the world, the facilities for the long-term storage or disposal of nuclear wastes.

\section{ACTIONS TO IMPLEMENT OUR NUCLEAR POLICIES}

In order to implement the nuclear policies that I have outlined, major efforts will be required within the United States and by the many nations around the world with an interest in nuclear energy. To move forward with these efforts, I am today taking a number of actions and making a number of proposals to other nations.

\section{Change in U.S. Policy on Nuclear Fuel Reprocessing}

With respect to nuclear fuel reprocessing, I am directing agencies of the executive branch to implement my decision to delay commercialization of reprocessing activities in the United States until uncertainties are resolved. Specifically, I am:

-- Directing the Administrator of the Energy Research and Development Administration (ERDA) to:

- change ERDA policies and programs which heretofore have been based on the assumption that reprocessing would proceed;

- encourage prompt action to expand spent fuel storage facilities, thus assuring utilities that they need not be concerned about shutdown of nuclear reactors because of delays; and

- identify the research and development efforts needed to investigate the feasibility of recovering the energy value from used nuclear fuel without separating plutonium.

\section{Restraint in the Transfer of Sensitive Nuclear Technology and Facilities}

Despite the gains in controlling proliferation that have been made, the dangers posed by reprocessing and the prospect of uncontrolled availability of plutonium require further, decisive international action.

Effective control of the parallel risk of spreading uranium enrichment technology is also necessary. To meet these dangers:

-- I call upon all nations to join with us in exercising maximum restraint in the transfer of reprocessing and enrichment technology and facilities by avoiding such sensitive exports or commitments for a period of at least 3 years.

This will allow suppliers and consumers to work together to establish reliable means for meeting nuclear needs with-minimum risk, as we assess carefully the wisdom of plutonium use. As we proceed in these efforts, we must not be influenced by pressures to

\section{Reprocessing Evaluation Program}

The world community requires an aggressive program to build the international controls and cooperative regimes I have just outlined. I am prepared to mount such a program in the United States.

-- I am directing the Administrator of ERDA to:

- Begin immediately to define a reprocessing and recycle evaluation program consistent with meeting our international objectives outlined earlier in this statement. This program should complement the Nuclear Regulatory Commission's (NRC) ongoing considerations of safety 
safeguards and environmental requirements for reprocessing and recycling activities, particularly its Generic Environmental Statement on Mixed Oxide Fuels.

- Investigate the feasibility of recovering the energy value from used nuclear fuel without separating our plutonium.

-- I am directing the Secretary of State to invite other nations to participate in designing and carrying out ERDA's reprocessing and recycle evaluation program, consistent with our international energy cooperation and nonproliferation objectives. I will direct that actions carried out in the U.S. in connection with this program be subjected to full IAEA safeguards and inspections.

\subsubsection{Nuclear Energy Policy Study Group, Nuclear Power Issues and Choices, often called Ford/MITRE study, Ford Foundation, 1977.}

It appears this report was influential as President Carter seems to have adopted all of its

recommendations regarding nuclear power, listed below. Indeed, much of its language, such as "plutonium economy" continue to this day. Yet, even it called for continuation of R\&D on breeders.

\section{Overview}

In the past, the waste disposal problem has generally been approached on the assumption that spent fuel would be reprocessed to recover plutonium for recycle. Decisions on disposal were continually deferred pending successful introduction of plutonium recycle. As a consequence, it is widely believed that reprocessing is a necessary stage in the waste disposal process. However, if plutonium it not recycled in light-water reactors or used eventually in breeders, there is no reason to reprocess spent reactor fuel. In fact, reprocessing potentially increases short-term risks associated with management of nuclear wastes and does not significantly reduce long-term risks after disposal. Spent fuel can be disposed of directly, and probably at costs comparable to those for reprocessed wastes. Therefore, if plutonium reprocessing for recycle in LWRs is deferred indefinitely as we recommend, waste disposal is made no more difficult.[page 34]

\section{Nuclear Power and Proliferation of Nuclear Weapons}

At the present moment, the nonproliferation venture is under test. The ambiguous Indian "peaceful" explosion of 1974 was a reminder of the nuclear weapons potential of a growing number of states. At international tension points, rival insecure or ambitious states confront each other. If one or more states overtly "go nuclear" in the near future, there is risk of a chain reaction of nuclear commitments by imitators or rivals. At this crucial time, nuclear power is spreading and bringing with it growing basic nuclear capabilities. In the United States and in other countries with nuclear power programs, technical decisions are impending whether to proceed with plutonium reprocessing and recycle and with breeder development, which could constitute a watershed for proliferation.[page 272]

\section{Domestic nuclear energy part of Summary and Conclusions in chapter on Nuclear Power and Proliferation of Nuclear Weapons}

The following measures would have major nonproliferation significance:

- A clear decision to defer plutonium reprocessing and recycle.

- Deemphasis of the breeder program with deferral of the early date for commercialization.

- Reduced priority for nuclear power in energy research and planning, in a framework giving equal weight to coal in the short term and alternative replenishable energy sources over the long term. 
- Avoidance of promotion of nuclear power both at home and abroad.

- Orderly expansion of enrichment facilities to correspond to realistic projections of future demand at home and abroad.

- Continued refusal to export plutonium separation and enrichment technology, coupled with efforts to achieve similar action by other suppliers.

- Approval of nuclear exports only where consistent with U.S. security interests and obligations and nonproliferation policy.[pp. 298-299]

\section{Conclusion (entire section from the chapter on Plutonium Reprocessing and Recycle)}

There is no compelling national interest to be served by reprocessing. There appears to be little, if any, economic incentive and it is unlikely that reprocessing and recycle could proceed without subsidy. The noneconomic benefits of reprocessing are small: fuel supply for LWRs would be little enhanced; present experience with reprocessing or plutonium stockpiles has little present value since the introduction of breeders is sufficiently far in the future and uncertain; and contemporary waste management risks with reprocessing are likely larger than possible reductions in long-term hazards from disposal. Health risks and new accident risks argue against reprocessing. But the most severe risks from reprocessing and recycle are the increased opportunities for the proliferation of national weapons capabilities and the terrorist danger associated with plutonium in the fuel cycle.

In these circumstances, we believe that reprocessing should be deferred indefinitely by the United States and no effort should be made to subsidize the completion or operation of existing facilities. The United States should work to reduce the cost and improve the availability of alternatives to reprocessing worldwide and seek to restrain separation and use of plutonium.[Page 333]

\section{Conclusion (entire section from chapter on Breeder Reactors)}

There is no question that the present version of the breeder stressed in the U.S. program, the plutoniumcycle LMFBR, will successfully generate power. It thus provides insurance against very high energy costs in the future. The hard question concerns the timetable on which a breeder might have sufficient economic merit, compared with other sources, to outweigh the potentially large social costs associated with a plutonium fuel cycle.

On the basis of our analysis, we conclude that there is little advantage in terms of economics or energy supply assurance in early commercial introduction of LMFBRs. Introduction of the breeder may be deferred for ten, twenty, or more years without seriously affecting the economic health or energy security of the United States. As long as there is a world market in low-enriched uranium, a similar conclusion appears to apply to other countries. The social costs associated in the breeder introduction argue strongly for deferral.

The relaxation in the breeder timetable recommended here has implications for the nature of the U.S. strategy to research and development on fission alternatives. There is time to pursue a broader research and development program on the breeders and on more efficient converter reactors. Delay will permit the development of more successful breeders should they be needed. In such a program, the Clinch River project, as presently conceived is not necessary and could be canceled without harming the long-term prospects for breeders. In fact, a premature demonstration could even be detrimental to these prospects.

It is important to continue work on the breeder, with a longer time horizon and an emphasis on its role as insurance. The goal should be to provide a range of more attractive choices at a series of decision points extending into the early decades of the next century. [page 362] 


\subsubsection{J. E. Carter, "Nuclear Nonproliferation Policy," PD/NSC-8, March 24, 1977, Declassified on March 15, 1994.}

Curiously, the public statement at the time mentions Barnwell by name, but PD/NSC-8 does not. PD/NSC-8 mentions Clinch River by name, but the public statement does not. GAO documents from this time period, however, make it clear that it was clear at the time that Carter wanted to terminate both $C R B R$ and Barnwell.

It shall be a principle U.S. security objective to prevent the spread of nuclear explosive - or near explosive - capabilities to countries which do not now process them. To this end U.S. non-proliferation policy shall be directed at preventing the development and use of sensitive nuclear power technologies which involve direct access to plutonium, highly enriched uranium, or other weapons useable material in non-nuclear weapons states, and at minimizing the global accumulation of these materials.

1. Specifically, the U.S. will seek a pause among all nations in sensitive nuclear developments in order to initiate and actively participate in, an intensive international nuclear fuel cycle re-evaluation program (IFCEP) whose technical aspects shall concern the development and promotion of alternative, nonsensitive, nuclear fuel cycles. This program will include both nuclear supplier and recipient nations.

2. For its part the United States Government will:

-- Indefinitely defer the commercial reprocessing and recycle of plutonium in the U.S.

-- Restructure the U.S. breeder reactor program so as to emphasize alternative designs to the plutonium breeder, and to meet a later date for possible commercialization. As a first step the need for the current prototype reactor, the Clinch River project, will be reassessed.

-- Redirect the funding of U.S. nuclear research and development programs so as to concentrate on the development of alternative nuclear fuel cycles which do not involve access to weapons useable materials."

The NSC Ad Hoc Group, established in PD-8, is directed to:

-- prepare an submit by March 31 a comprehensive list of all activities, facilities and technologies related to nuclear power, which involve direct access to weapons useable materials;

-- prepare and submit by April 5, proposed nuclear export policies, including: a summary of current applications for export of Highly Enriched Uranium and plutonium; criteria which should be applied to nuclear exports at the licensing stage; a list of criteria and conditions which should be required for new and amended agreements for cooperation, and necessary revisions in existing agreements; explicit options covering U.S. policies on consent to retransfer, reprocess, reexplore and reuse U.S.supplied fuels, Highly Enriched Uranium, plutonium, and materials irradiated in US.-supplied facilities; and legislative proposals to implement these recommendations;

-- prepare and submit by May 1, a detailed study of measures the U.S. might take so as to be able to offer nuclear fuel assurances to nations participating in the International Fuel Cycle Evaluation Program, including: rigorous revised estimates of future nuclear energy demand; measures to expand U.S. enrichment capacity; analysis and justification of U.S. stockpile programs; recommendations for appropriate terms and conditions for future toll enrichment contracts; assessment of the benefits of declaring an open season on enrichment contract; exploration of international undertakings and agreements; and other short and long-term options for providing nuclear fuel assurances and collaborating with other suppliers; 
-- Prepare and submit by May 1, a thorough study of measures the U.S. might take concerning nuclear fuel storage including: measures to expand U.S. spent fuel storage and transportation capacity; proposals for meeting the storage needs of those participating in the International Fuel Cycle Evaluation Program; analysis of the advantages and disadvantages of international spent fuel storage (but not plutonium storage which the U.S. shall discourage); and measures to accelerate the development, demonstration and licensing of long-term spent fuel storage, both retrievable and terminal."

\subsubsection{Jimmy Carter Library, Records of the Speech Writer's Office, Statement on Nuclear Power Policy, April 7, 1977.}

The full title of this statement at the American Presidency Project (www.presidency.ucsb.edu) is "Nuclear Power Policy Statement on Decisions Reached Following a Review". It would be interesting to read that review.

Curiously, the public statement at the time mentions Barnwell by name, but PD/NSC-8 does not. PD/NSC-8 mentions Clinch River by name, but the public statement does not.

There is no dilemma today more difficult to resolve than that connected with the use of nuclear power. Many countries see nuclear power as the only real opportunity, at least in this century, to reduce the dependence of their economic well-being on foreign oil--an energy source of uncertain availability, growing price, and ultimate exhaustion. The U.S., by contrast, has a major domestic energy source--coal-but its use is not without penalties, and our plans also call for the use of nuclear power as a share in our energy production.

The benefits of nuclear power are thus very real and practical. But a serious risk accompanies worldwide use of nuclear power--the risk that components of the nuclear power process will be turned to providing atomic weapons.

We took an important step in reducing the risk of expanding possession of atomic weapons through the nonproliferation treaty, whereby more than 100 nations have agreed not to develop such explosives. But we must go further. The U.S. is deeply concerned about the consequences for all nations of a further spread of nuclear weapons or explosive capabilities. We believe that these risks would be vastly increased by the further spread of sensitive technologies which entail direct access to plutonium, highly enriched uranium, or other weapons usable material. The question I have had under review from my first day in office is how can that be accomplished without forgoing the tangible benefits of nuclear power.

We are now completing an extremely thorough review of all the issues that bear on the use of nuclear power. We have concluded that the serious consequences of proliferation and direct implications for peace and security--as well as strong scientific and economic evidence--require:

--a major change in U.S. domestic nuclear energy policies and programs; and

--a concerted effort among all nations to find better answers to the problems and risks accompanying the increased use of nuclear power.

I am announcing today some of my decisions resulting from that review.

First, we will defer indefinitely the commercial reprocessing and recycling of the plutonium produced in the U.S. nuclear power programs. From our own experience, we have concluded that a viable and economic nuclear power program can be sustained without such reprocessing and recycling. The plant at Barnwell, South Carolina, will receive neither Federal encouragement nor funding for its completion as a reprocessing facility. 
Second, we will restructure the U.S. breeder reactor program to give greater priority to alternative designs of the breeder and to defer the date when breeder reactors would be put into commercial use.

Third, we will redirect funding of U.S. nuclear research and development programs to accelerate our research into alternative nuclear fuel cycles which do not involve direct access to materials usable in nuclear weapons.

Fourth, we will increase U.S. production capacity for enriched uranium to provide adequate and timely supply of nuclear fuels for domestic and foreign needs.

Fifth, we will propose the necessary legislative steps to permit the U.S. to offer nuclear fuel supply contracts and guarantee delivery of such nuclear fuel to other countries.

Sixth, we will continue to embargo the export of equipment or technology that would permit uranium enrichment and chemical reprocessing.

Seventh, we will continue discussions with supplying and recipient countries alike, of a wide range of international approaches and frameworks that will permit all nations to achieve their energy objectives while reducing the spread of nuclear explosive capability. Among other things, we will explore the establishment of an international nuclear fuel cycle evaluation program aimed at developing alternative fuel cycles and a variety of international and U.S. measures to assure access to nuclear fuel supplies and spent fuel storage for nations sharing common nonproliferation objectives.

We will continue to consult very closely with a number of governments regarding the most desirable multilateral and bilateral arrangements for assuring that nuclear energy is creatively harnessed for peaceful economic purposes. Our intent is to develop wider international cooperation in regard to this vital issue through systematic and thorough international consultations.

\subsubsection{Jimmy Carter, "Nuclear Non-Proliferation - Message to Congress," April 27, 1977.}

The need to halt nuclear proliferation is one of mankind's most pressing challenges. Members of my Administration are now engaged in international discussions to find ways of controlling the spread of nuclear explosive capability without depriving any nation of the means to satisfy its energy needs. The domestic nuclear policies which I have already put forward will place our nation in a leadership position, setting a positive example for other nuclear suppliers as well as demonstrating the strength of our concern here at home for the hazards of a plutonium economy. Today I am submitting to the Congress a bill which would establish for the United States a strong and effective non-proliferation policy.

Since I intend personally to oversee Executive Branch actions affecting nonproliferation, I do not think a substantial reorganization of the responsibility for nuclear exports within the Executive Branch is necessary. This conclusion is shared by the Nuclear Regulatory Commission.

The need for prompt action is great. Until domestic legislation is enacted, other countries will be reluctant to renegotiate their agreements with us, because they will fear that new legislation might suddenly change the terms of cooperation. If the incentives we offer them to renegotiate with us are not attractive enough, the United States could lose important existing safeguards and controls. And if our policy is too weak, we could find ourselves powerless to restrain a deadly worldwide expansion of nuclear explosive capability. I believe the legislation now submitted to you strikes the necessary balance. 


\subsubsection{Jimmy Carter, "Nuclear Non-Proliferation Fact Sheet on the Proposed Nuclear Non-Proliferation Policy Act of 1977," April 27, 1977.}

Together, Carter's statement and this fact sheet contain the request to Congress on the contents of what eventually became the Nuclear Non-Proliferation Act of 1978.

1. The bill establishes for the first time a statutory requirement forbidding the independent Nuclear Regulatory Commission (NRC) from granting a license to export nuclear materials or facilities until it has been notified by the executive branch of its judgment that the issuance of a license "will not be inimicable to the common defense and security." This judgment will be reached by the Departments of State, Defense, Commerce, the Arms Control and Disarmament Agency, and the Energy Research and Development Administration.

This power was indeed granted to a considerable degree - a power that President Bush used in 1992.

As a reminder that the NRC is an independent agency, Carter wanted the Act to address disagreements between the executive branch and the NRC.

5. The bill provides the flexibility needed to deal with the many different situations and nations involved. For example, it makes the necessary exceptions for licenses under existing multilateral agreements. It also establishes an efficient mechanism for the President and Congress to review cases where the executive branch and the independent NRC differ on the granting of a proposed export license. And it permits the President to grant exceptions from the stiff new conditions required for new agreements for cooperation, if he considers that this is in our overall non-proliferation interest.

\subsubsection{GAO, "Nuclear Energy's Dilemma: Disposing of Hazardous Radioactive Waste Safely," report EMD-77-41, September 9, 1977.}

Note that the reason given for lack of disposition of spent fuel at the nation's reactors is the lack of reprocessing capability. And, GAO differentiates the terms "spent fuel" from HLW on the basis that the former may be reprocessed.

This report discusses the various possible types of geology. ERDA's plan at the time was to have six repositories for geographic balance and program risk reduction (in case some were found unsuitable), at an estimated cost of $\$ 200$ million per repository. At this time, potential bedded salt sites in Kansas and Michigan had both been rejected (in 1972 and 1976 respectively) for a combination of technical and public reasons.

Spent fuel has not yet been defined by the Nuclear Regulatory Commission as high level waste and may not be because of its potential value as a source of fuel if reprocessed. This report will consider spent fuel as a "potential" high level waste.

Commercial reactor spent fuel is accumulating at nuclear powerplants because there are no commercial reprocessors now operating in the United States. Resumption of reprocessing does not seem probable in the near future since President Carter has indefinitely deferred commercial reprocessing of spent fuel.

If it is finally decided that there will be no further commercial reprocessing, spent fuel elements from existing and future civilian power reactors probably will have to be managed as high level radioactive waste. Meanwhile, nuclear powerplants have had to store their spent fuel in storage pools at the reactor sites. As a result, a backlog of spent fuel is accumulating at the powerplants. (See pp. 51 to 52.)

Since a tremendous backlog of spent fuel (potential high level waste) exists at nuclear powerplants because no commercial reprocessors are operating in the United States, utilities are adopting several 
options to increase their storage capacity. These capacities are being modified at existing reactors and larger storage facilities are being planned for new reactors. Spent fuel shipment to storage pools within a utility's nuclear powerplant system is another plan that utilities are considering.

Because the President has indefinitely deferred commercial reprocessing of nuclear spent fuel, the Energy Research and Development Administration has decided to initiate a project to store spent fuel in a proposed Surface Unreprocessed Fuel Facility. In the event the President and the Congress ultimately decide against commercial reprocessing, spent fuel--if defined as waste--might have to be disposed of in the geologic repositories. This will affect the six commercial waste repositories currently being planned by the Energy Research and Development Administration.

The six repositories were arrived at mainly to spread nuclear waste regionally throughout the Nation and minimize any setback to the program should a potential site(s) prove unacceptable. Storage and/or disposal of spent fuel in geological formations requires more acreage than is needed for storage and/or disposal of high level waste.

\subsubsection{Jimmy Carter, "International Nuclear Fuel Cycle Evaluation Remarks at the First Plenary Session of the Organizing Conference," October 19, 1977.}

I have a feeling that the need for atomic power itself for peaceful uses has perhaps been greatly exaggerated. And I hope that all the nations represented here and others will assess alternatives to turning to this source of power, if for no other reasons than because of economic considerations.

It's important that we know what potential nuclear fuel cycles are available to us, the quantity and the location of uranium and thorium and other nuclear fuels, the methods used for extraction, the methods used and the costs for enrichment, possible distribution systems, the proper design and use, standardization of powerplants, safety of people who live near them, proper siting considerations, the political objections to atomic powerplants themselves, the possible need for breeder reactors, the handling of spent fuel, the need or absence of a need for reprocessing the spent fuel, and international safeguards that will prevent the development of explosives.

We are eager to cooperate as a nation which is a consumer and also a supplier. We want to be sure that where there is a legitimate need and where there's a mutually agreed upon nonproliferation restraint, that there be an adequate supply of nuclear fuel.

I think an international fuel bank should be established, so that if there is a temporary breakdown in the bilateral supply of nuclear fuel, that there might be a reservoir of fuel to be supplied under those circumstances. And we'll certainly contribute our own technical ability and our own portion of the enriched uranium supplies for that purpose.

We are very eager, also, to help solve the problem of the disposal of spent nuclear fuel itself. We can't provide storage for the major portion of the world's spent fuel, but we are willing to cooperate. And when a nation demonstrates to us your need for spent nuclear fuel storage, we hope to be prepared to accept that responsibility, working closely with you.

All the costs of the nuclear fuel cycle should be accurately known as well as possible. And there should be an open-minded approach to this very controversial and very difficult subject. 


\subsubsection{GAO, "Review of the Present Status of the Clinch River Breeder Reactor Project," report EMD-78-49, March 6, 1978.}

Current nuclear reactors can use only 1 to 2 percent of the potential energy in uranium. In contrast, the LMFBR actually creates (breeds) more fuel than it uses and can extract more than 60 percent of the energy in uranium. The LMFBR has the potential for providing a virtually inexhaustible energy source through the 21 st century and beyond.

The following two paragraphs indicate the GAO's position that the budget (a law) superseded Carter's policy "proposal."

The administration is concerned that increased plutonium availability will encourage nuclear proliferation. Therefore, it has proposed to defer any further U.S. commitment to advanced nuclear technologies that use plutonium as a fuel. The administration proposes to drastically reduce the LMFBR program, including cancelling construction of the CRBR and all component construction, licensing, and commercialization efforts.

In keeping with its April 1977 proposal to curtail the scope of the project, the administration had planned to begin terminating certain program activities at the end of July 19. However, by letter dated June 23, 1977, B-115398, this Office held that the authorities and restrictions in the basic legislation authorizing construction of the CRBR project (section 106 of Public Law 91-273, as amended by section 103 of Public Law 94-187) require that any funds appropriated for the CRBR project can only be used to continue the project and not to terminate it. In short, the administration cannot use appropriated funds to terminate the project without specific additional authority. Since June, the Department of Energy has continued the CRBR project in what could be called an austere mode. While engineering design and major component fabrication have continued, no site preparation or construction activities have begun, and there have been no licensing activities since April 1977.

\subsubsection{Jimmy Carter, "Nuclear Non-Proliferation Act of 1978 Statement on signing H.R. 8638 into Law," March 10, 1978.}

This is Carter's "signing" statement upon signing the Nuclear Non-Proliferation Act of 1978. That Act dealt with export controls. In this statement, Carter repeats his opposition to reprocessing, Barnwell, $C R B R$, which were not part of the Act.

I am pleased to sign into law today H.R. 8638, the Nuclear Non-Proliferation Act of 1978. Enactment of this legislation takes us a major step toward fulfillment of an objective which the United States shares with other nations - a halt in the spread of nuclear weapons capability while preserving the peaceful use of nuclear energy.

The Congress has responded to this challenge with both care and courage in establishing a framework for ensuring that we meet these objectives. Senators Ribicoff, Glenn, and Percy, Representatives Zablocki, Bingham, and Findley, their colleagues on the committees which developed this bill, and their staffs have my respect and my thanks for their leadership on this issue. It has been a privilege for me, as it has been for Secretary Vance and other members of my administration, to work with them on the Nuclear NonProliferation Act of 1978.

Our efforts to prevent the spread of nuclear weapons began more than 30 years ago, when we went to the United Nations with an offer to place certain aspects of nuclear energy under international ownership and control. The passage of the Atomic Energy Act of 1954 and the adoption of the Non-Proliferation Treaty by the United Nations in 1968 and now this law, each have moved us further toward attainment of our nonproliferation goals. 
On April 7 and 27 of last year, I outlined the policies and programs which we would implement to diminish proliferation risks. Today, I want to reaffirm this administration's strong commitment to that policy. We also recognize that nuclear power technologies now in operation, which do not involve nuclear fuel reprocessing, can and must provide an important source of energy for our Nation and for their countries. Our current once-through fuel cycle is and will continue to be a significant contributor to our energy supply. Properly managed, it can function without increasing the risks of proliferation. Our policy takes a responsible course between forgoing the energy benefits of nuclear power and becoming committed to commercialized use of plutonium before we know that we can deal safely with its risks.

I continue to oppose making premature and unnecessary commitments to commercialization of the fast breeder reactor and reprocessing, as exemplified in the United States by the Clinch River and Barnwell projects.

We and the other nations of the world must use the time we now have and pause to develop safer technologies, better institutional arrangements, and improved safeguards which will permit all nations to achieve their energy objectives while preventing the spread of nuclear weapons.

More than 40 nations have already joined with us in an International Nuclear Fuel Cycle Evaluation to explore and assess our means of meeting these twin goals. During this period of examination, the uranium-fueled reactors now in widespread operation can be used without incurring new proliferation risks. If our common search for improved institutions and technologies is to be successful, however, all nations will be required to avoid those steps which prejudice the outcome of the INFCE.

The Nuclear Non-Proliferation Act sets the conditions and criteria which will govern U.S. cooperation with other nations in our efforts to develop the peaceful use of nuclear energy. The encouragement of universal ratification of the Non-Proliferation Treaty is central to the act, as is the establishment of a comprehensive set of controls, including application of International Atomic Energy Agency safeguards and provision of a stable framework for international nuclear cooperation and commerce. The act will also make our export licensing process more predictable

\subsubsection{GAO, "An Evaluation of Federal Support of the Barnwell Reprocessing Plant and the Department of Energy's Spent Fuel Storage Policy," report EMD-78-97, July 20, 1978.}

This report was sent to Senator John Glenn. It gives a fairly clear explanation of what was happening in this time period to the Barnwell facility.

The footnote that appears in 3 pages is in the original GAO report.

\section{Document Resume}

In April 1977, the President announced a new policy to minimize risks of nuclear weapons proliferation which deferred indefinitely the commercialization of technologies that reprocess or depend on the recycle of plutonium. To carry out the policy, the President proposed that neither Federal funding nor support should be given to complete a large Commercial reprocessing facility being constructed at Barnwell, South Carolina. Later in 1977, the Department of Energy (DOE) announced that the Federal Government would begin accepting and taking title from utilities to spent nuclear fuel that previously was to be reprocessed

Findings/Conclusions: At Barnwell, spent fuel is separated into uranium and plutonium. The administration finds this process unacceptable and has taken initiatives to study, along with other countries, alternative fuel cycles. Allied-General Nuclear Services, Inc. has invested about $\$ 250$ million in the Barnwell complex with the encouragement of the former Atomic Energy Commission and the 
Nuclear Regulatory Commission. The Congress has recently funded research activates at Barnwell relating to spent fuel handling and storage, security and safeguards, and alternative fuel cycles. The administration believes this work duplicates other research efforts and should not be continued. GAO believes that the Congress should continue to fund short-term research studies at Barnwell until the completion of the international study on alternative fuel cycle technologies. Interim storage of spent fuel has become a part of the nuclear fuel cycle. It would be premature for DOE to build a new Governmentfinanced spent fuel storage facility before considering other alternatives.

Recommendations: The Secretary, DOE, before deciding to build a Government-financed facility should, in order of priority: work with and explore ways that utilities can solve their own spent fuel storage problem, gives further consideration to the use and expansion of existing away-from-reactor storage facilities, pursue industry interest to provide additional facilities, and consider the findings of the interagency task force which is evaluating issues facing the spent fuel storage policy.

\section{DIGEST}

For many years, the Government and utilities assumed that spent nuclear fuel from commercial reactors would be routinely reprocessed to separate the nuclear wastes and recover the residual uranium and plutonium. The radioactive wastes would be concentrated, packaged, and turned over to the Federal Government for disposal while the uranium and plutonium would be used again to fuel either light water or breeder reactors. [Page i]

In April 1977, however, the President announced a new policy on nuclear power which deferred indefinitely the commercialization of technologies that reprocess or depend on the recycle of plutonium. The reason for the policy was to reduce the availability of plutonium and to minimize the risks of nuclear weapons proliferation.[Page i]

To carry out the policy, the President has proposed to indefinitely defer the development of the Liquid Metal Fast Breeder Reactor and has said that Allied-General Nuclear Services, Inc. would not receive either Federal funding or support to complete a large commercial reprocessing facility being constructed at Barnwell, South Carolina.[Page i]

Later in 1977 the Department of Energy announced that the Federal Government would, at some unspecified future date, begin accepting and taking title to spent nuclear fuel from utilities that previously was to be reprocessed. Under this policy, spent fuel from utilities would be accepted upon payment of a one-time fee. The fee would cover the full cost to the Government for interim storage and final disposal of the spent fuel.[Page i]

\section{Federal Support of the Barnwell Reprocessing Plant}

Barnwell is the first large-scale commercial reprocessing venture in the United States. It is designed to reprocess 1,500 metric tons of spent reactor fuel per year. The Nuclear Regulatory Commission approved construction of some of the facilities before 1970 and three of the five major facilities at the complex are essentially complete.[Page ii]

Allied-General has already invested about $\$ 250$ million in the Barnwell complex. A recently completed Department study on alternative uses at Barnwell estimates that before the plant could operate continuously at design capacity, an additional capital investment of $\$ 380$ million to $\$ 585$ million would be needed. It is possible, however, that spent fuel could be reprocessed prior to the completion of the entire complex.(See pp. 4 to 6.)[Page ii]

Barnwell, as well as other reprocessing plants here and abroad, separates spent fuel into almost pure streams of uranium and plutonium. The Administration considers this unacceptable from a nuclear weapons proliferation standpoint and has taken initiatives to study, along with other countries, alternative 
fuel cycles and methods of reprocessing that might prevent proliferation. Until this international study is complete, Allied-General has said there is very little it can do to complete the Barnwell facility.[Page ii]

The President's decision to indefinitely defer commercial reprocessing reflects a major change in the Federal attitude toward Barnwell. While the Government did not provide any direct financial support to Allied-General, it created--through its previous policies and programs on nuclear power--an atmosphere favorable to reprocessing. The former Atomic Energy Commission, for example, offered verbal encouragement to Allied-General, provided it access to reprocessing technology, and sold it land on which to build the reprocessing complex. Likewise, the Nuclear Regulatory Commission, while imposing strict requirements, had not previously given Allied-General reason to believe that reprocessing and recycling activities could not eventually meet safety and environmental licensing criteria. (See pp. 6 to 8 .) [Page ii-iii]

Faced with the withdrawal of official Government support for conventional reprocessing and the termination of licensing proceedings, Allied-General's position was improved - at least temporarily-when Congress required the Department of Energy to spend $\$ 13$ million of its fiscal year 1978 research budget at Barnwell. Congress said, however, that the work at Barnwell should be consistent with the Administration's nonproliferation objectives and that the money not be used to further prepare the plant for reprocessing. In addition, committees in both houses of Congress have tentatively added between $\$ 13$ million and $\$ 18$ million to the Department's current budget request to continue work at Barnwell through fiscal year 1979. (See p. 8.) [Page iii]

The Department, after receiving the money from Congress, contracted with Allied-General for several studies and research activities relating to (1) spent fuel transportation, receiving, handling, and storage; (2) security and safeguards; and (3) alternative fuel cycles. The Administration believes this work duplicates other research efforts and should not be continued. GAO, during its review, discussed this with Department officials. Generally, high-level management agreed with and even helped develop the Administration's position. Other staff levels, however, do not believe that the work at Barnwell is duplicative but recognize that the Department should do a better job of matching any future work to its program objectives.[Page iii]

If Congress agrees with the Administration's position and discontinues funding, Allied-General has said that it will decrease operations and consider putting the plant in a mothballed status. While the plant could be brought from mothballed to operational status at some future time, the Department estimates that it would take about 4 years and cost between $\$ 75$ million and $\$ 115$ million. It is also an option, according to Allied-General, that it would eventually dismantle the plant and take legal action to recoup its losses from the Federal Government. In any event, the lack of continued Government funding is likely to result in the termination of some or all activities at the plant and the loss or transfer of people key to the reprocessing operation.[Page iii-iv]

If funding is continued by the Congress, money could be used to continue research activities, assist in the development of other facilities at the plant, expand the onsite spent fuel storage facility, or purchase Barnwell for use either as a national or international fuel cycle center. The Administration believes, however, that such funding would hinder its international nonproliferation objectives and cause other countries to doubt the U.S. commitment to the deferral of commercial reprocessing technologies.[Page iv]

GAO believes that the Congress should continue to fund short-term research studies at Barnwell until the completion of the international study on alternative fuel cycle technologies. This will keep the facilities and key people available in the event the United States decides, as a result of the study, that some method of reprocessing is consistent with its nonproliferation objectives.[Page iv]

GAO believes, however, that it is important that the Department not wait on congressional initiatives to plan work at Barnwell and make it compatible with existing programs. Also, GAO emphasizes that this 
should be a short term option only. If, at the completion of the international study, the Administration maintains its current policies, GAO would recommend that the Congress terminate its funding initiatives. At that time it would be Allied-General's decision to either maintain or reduce the operating status at Barnwell.(See pp. 8 to 13.)[Page iv]

\section{From Chapter 2. Federal Support of the Barnwell Reprocessing Plant}

In addition, NRC, in consideration of the President's policy, has terminated all licensing proceedings at Barnwell and said it will not consider reopening them until after these major studies are completed. ${ }^{\mathrm{s}}$ NRC justifies this decision by noting that

-- continued licensing could lead other nations to question the U.S. commitment to defer commercial reprocessing and plutonium recycle,

-- congressional actions appear to support the President's nonproliferation objectives and policy on plutonium recycling,

-- previous court decisions and existing regulations give the Commission broad authority to terminate licensing proceedings, and

-- final environmental and safety considerations cannot be completed until the INFCE and NASAP studies are completed and all viable alternatives to plutonium recycling are known and evaluated.[Page 7]

These policies reflect a major change in the Federal attitude toward Barnwell. While the Government did not provide any direct financial support to Allied-General, it created - through its policies and programs on nuclear power--an atmosphere favorable to reprocessing. The former Atomic Energy Commission, for example, offered verbal encouragement to Allied-General, provided it access to reprocessing technology, and sold it land on which to build the reprocessing complex. Likewise, NRC, while imposing strict requirements, had not previously given Allied-General reasons to believe that reprocessing and recycling activities could not eventually meet safety and environmental licensing criteria.[Page 7-8]

Later on, there is this interesting footnote in regard to a DOE study issued in April 1978. COEX is evidently not a new idea in the GNEP time period. It also seems not to have changed the debate on Barnwell.

According to the DOE report, Barnwell can be easily adapted in most cases to coprocess or produce combination streams of plutonium and uranium (or nuclear wastes) that are not as susceptible to diversion as conventional reprocessing modes.[Page 10]

In October $1977 \mathrm{DOE}$ announced a new spent fuel policy which was described as "a logical extention, given the indefinite deferral of reprocessing, of the long-established Federal responsibility for permanent disposal of high-level waste." [DOE news release dated October 18, 1977.] The policy would also remove the uncertainty facing utilities of having to store spent fuel for an indefinite period of time.

Some key elements of the policy were that:

-- The Federal Government would offer, on a voluntary basis, to accept and take title to spent fuel upon delivery to a Government-approved storage site at user expense.

-- The fuel owner must pay a one-time fee that will cover the full cost to the Government of providing for interim storage and permanent disposal of the spent fuel should that be required.

-- No credit would be allowed for either the plutonium or uranium in the spent fuel. However, if the recovery of the fuel value is ever approved, spent fuel may be returned or compensation made for the

s. [footnote in original] With the exception of the spent fuel storage facility. 
net fuel value. [Footnote - The difference between the value of the uranium and the plutonium less the cost of fuel recycle.] [Page 14-15]

DOE said preliminary estimates of storage and disposal costs indicate that the total fee should add less than 1 mill (one-tenth of a cent) per kilowatt hour to nuclear power electricity costs, which are now about 40 mills per kilowatt hour to the consumer. Also DOE said it will develop detailed storage and disposal cost estimates which would be published for comment prior to official adoption. [Page 15]

DOE officials told us that a 5,000 metric ton spent fuel storage facility is needed by 1983 . This will be large enough to store the estimated spent fuel transfers from utilities through the year 1986. [Page 21]

There are currently two options under consideration - either seek private storage services or provide Government financing for the facility. DOE officials estimate that a 5,000 metric ton storage facility would cost about $\$ 210$ million, no matter how it is financed. Further, DOE officials believe a Government-financed facility could meet the 1983 date but a privately financed facility could not be available until at least 1984 . The latter date reflects the additional time necessary to seek appropriate legislation, negotiate contracts, and obtain licensing approval. To meet the 1983 date, DOE officials project that the site must be selected by September or October 1978, the environmental report and the safety analysis report must be submitted by March of 1979, and construction must begin by the middle of 1980. DOE has activities ongoing to meet these dates. [Page 21-22]

\subsubsection{Jimmy Carter, "Clinch River Breeder Reactor Statement on Action by the House Science and Technology Committee," April 27, 1979.}

From Carter's 1977 nonproliferation statement through the end of his term, Carter and Congress continued to disagree about CRBR. Carter fought the annual funding by Congress, as noted below. No claim of Carter's legal authority to stop CRBR has been found.

Thursday's House Science and Technology Committee's vote to proceed with construction of the liquid metal fast breeder nuclear reactor at Clinch River was a significant setback to a rational and responsible nuclear energy policy. In spite of forceful leadership by the committee's chairman, Don Fuqua, the members of the committee voted to force continuation of spending at a rate of $\$ 15$ million per month, or more, for this unneeded project.

The Clinch River breeder reactor is technically unsound. It is a waste of more than $11 / 2$ billion of our taxpayers' dollars. It is inconsistent with our nonproliferation policy.

During a time when our attention should be riveted on improving the safety and operation procedures of the light water reactor technology which we now use, the debate over the Clinch River breeder reactor spurred on by special interests has diverted our time and resources toward a new and unnecessary plutonium technology. I have proposed an orderly and scientifically sound breeder research and development program which will make this technology available to us if and when it is needed.

Now we do not need the Clinch River breeder reactor, which was originally undertaken as a crash program to commercialize plutonium breeder reactors. Corners were cut, and designs have been locked into place without the benefit of the scientific improvements which research continues to make available.

We have plenty of time to develop a safe, efficient, technically sound, and proliferation-resistant breeder design. We have an immediate need to make needed assessments of and improve the safety of our current nuclear technology, which the Three Mile Island accident shows are so vitally needed. We do not need to decide now to build a plant based on a wholly new technology about which far less is known than the nuclear reactors we now use. 
I want to repeat my longstanding and consistent request to the Congress to deny the strong efforts of the big utilities and energy companies and to terminate the Clinch River breeder reactor. We have a far more immediate task at hand - putting our existing nuclear power policies in order.

I will continue to oppose the construction of this unnecessary, wasteful, and unsound project on the House floor and in the Senate. I urge all those who share my concerns to make their voices heard.

\subsubsection{GAO, "The Clinch River Breeder Reactor - Should Congress Continue to Fund it?," report EMD-79-62, May 7, 1979.}

For the past 2 years, the Congress and the administration have been in a stalemate over the Clinch River Breeder Reactor Project. The Congress is appropriating funds to continue the project but the administration wants to terminate it. [cover page]

This report's purpose is to help congressional decision makers focus on whether the Clinch River Breeder Reactor should be built. The weight of evidence gathered by GAO supports continuation of the Clinch River Breeder Reactor Project if this Nation wishes to maintain a strong breeder reactor research and development program. GAO notes that the administration is on record in support of a strong breeder reactor research and development program. [cover page]

In 1970 , when it was originally conceived, the plant was expected to cost $\$ 700$ million. However, since that time, technical, environmental, and economic issues surfaced which caused project schedules to slip and costs to escalate. It is now estimated that the facility will cost about $\$ 2.6$ billion and will not be operational until 1987. (See pp. 3 and 18.) [Page i]

... the administration is rigid in its opposition to building the Clinch River Breeder Reactor. Thus, if Congress does continue to fund that project, further efforts will be required to remove the impasse between continued funding and the administration's position in order to assure that the funds authorized and appropriated are productively used.[Page vi]

Originally the Clinch River project was expected to be completed and to begin operating in 1980 at a cost of $\$ 700$ million. In the early 1970 s, however, a number of environmental, technical, and economic issues surfaced which necessitated a reappraisal of the cost and schedule estimates. As a result, by 1974 the scheduled plant operational date had slipped to 1982 and the cost estimate had risen to $\$ 1.7$ billion. The demise of AEC and the creation of ERDA brought increased competition for research and development funds, and in a 1976 revised LMFBR program plan, ERDA further slipped the project's operating date to 1983 and revised the cost estimate to $\$ 1.9$ billion. The Clinch River project continued under ERDA's revised LMFBR program plan until April 1977. [Page 3]

The $\$ 1.9$ billion increase in total estimated project cost has been used by the administration and critics of the LMFBR program as evidence that the Clinch River project is not cost beneficial and is no longer justified. However, much of the cost increases are attributable to factors beyond the control of the project management. It has been estimated that over $\$ 700$ million of the estimated cost increase was cost escalation that occurred during the project's lifetime. However, a large portion of this amount occurred during the early project development stage. We found one estimate to be as high as $\$ 560$ million. Another $\$ 410$ million is attributable to the current stalemate over whether the project should be continued. These two factors account for over $\$ 1.1$ billion or well over 50 percent of the total cost increase. [Page 19]

Another key element is that one-third of the total project cost or about $\$ 830$ million, represents first-of-akind project costs since off-the-shelf items are not yet yet available. Thus, these costs represents more of a research and development cost rather than Clinch River project costs. [Page 19] 


\title{
4.1.22 GAO, "Nuclear Reactor Options to Reduce the Risk of Proliferation and to Succeed Current Light Water Reactor Technology," report EMD-79-15, May 23, 1979.
}

\author{
Note that this US General Accounting Office described Carter's 1977 statement as "proposed".
}

The discharged or spent fuel from both the light water reactor and the liquid metal fast breeder reactor can be reprocessed to extract plutonium and other elements. The extracted plutonium can then be used again as nuclear fuel. The problem is that plutonium can also be used to make nuclear weapons.

Since the 1950 s, there has been considerable concern that nations with nuclear powerplants, but without nuclear weapons, might attempt to reprocess spent nuclear fuel to acquire plutonium for nuclear weapons. To reduce the risk of nuclear weapons proliferation from reactor systems which involve plutonium reprocessing, the President proposed in April 1977 that the United States (1) indefinitely defer commercial reprocessing and recycling of plutonium as well as the commercial introduction of the liquid metal fast breeder reactor, (2) reduce funding for the liquid metal fast breeder reactor research and development program and redirect efforts towards evaluating alternative nuclear concepts and fuel cycles, and (3) cancel construction of the Clinch River Breeder Reactor--the Nation's first liquid metal fast breeder reactor demonstration powerplant. Since April 1977 most of the President's proposals have been carried out as part of current energy policy.

Chairman of the Joint Economic Committee, GAO reviewed (1) technical methods to reduce the risk of nuclear proliferation from spent fuel reprocessing, including making use of the thorium fuel cycle, (2) institutional methods to reduce the risk of nuclear proliferation, and (3) status and obstacles associated with developing various alternative nuclear fission concepts,

\section{TECHNICAL METHODS OF REDUCING THE RISK OF PROLIFERATIO FROM REPROCESSING NUCLEAR FUEL}

To determine if current nuclear reactors can be made "proliferation-proof," GAO reviewed four proposed technical alterations to current nuclear power systems.

--Coprocessing - a form of reprocessing whereby plutonium, which could otherwise be extracted for use in weapons, is never completely separated from the spent reactor fuel. The highly radioactive spent fuel would make handling extremely difficult.

Deeper into the report, it states that Coprocessing refers to a form of reprocessing, whereby plutonium and unused uranium are never completely separated from the spent reactor fuel. Plutonium and unused uranium are kept in combination so that low concentrations of plutonium are maintained, and further chemical processing would be required to separate them.

The additional step to separate the coprocessed material to get plutonium is not, however, technologically difficult. Marginal adjustments to operating conditions could enable a coprocessing facility to produce pure plutonium. Consequently, coprocessing alone is not a major step towards reducing the risk of proliferation by nations. It has potential for helping to prevent the diversion of pure plutonium by terrorists. Coprocessed material diverted by terrorists would have to be chemically processed to make a nuclear bomb, which may be beyond their capabilities.

-- Spiking - a process in which extracted plutonium is deliberately contaminated with dangerous levels of radiation to make handling difficult.

-- Colocation - a concept whereby all parts of the fuel cycle providing access to plutonium are placed at a single, centralized location. 
-- The Civex process - an alternative to current reprocessing techniques which involves such features as coprocessing and spiking.

None of these technical methods is proliferation-proof. GAO found that none of the methods presents insurmountable obstacles to a nation or subnational terrorist group intent on diverting nuclear material to make weapons. In addition, none of the technical methods has been developed beyond the experimental state. Each would, however, make the diversion of weapons material more difficult, thereby lowering the risk of nuclear proliferation.

Another possible method for reducing the risk of nuclear weapons proliferation is to phase out the uranium fuel cycle and adopt the thorium fuel cycle. GAO found that, in some respects, the thorium fuel cycle is superior to the uranium cycle. However, the thorium fuel cycle is not proliferation proof as it produces a form of uranium which is a weapons material as well as some plutonium. Also, the thorium fuel cycle has not been demonstrated and major economic and development questions must be answered.

\subsubsection{GAO, "Federal Facilities for Storing Spent Nuclear Fuel - Are They Needed," report EMD-79-82, June 27, 1979.}

Savannah River Reservation began a conceptual design study for a 5,000 metric ton spent-fuel storage facility. This study, completed in late 1978 at a cost of $\$ 950,000$ estimated that such a facility could be built at any Government site for $\$ 270$ million and could be ready to receive spent fuel in January 1983-assuming site selection and design work was started in fiscal year 1978. [Page 12]

DOE subsequently updated this information and estimated that the facility would cost approximately $\$ 290$ million to construct but could not be ready until September 1985. [Page 12]

\subsubsection{Final Report of the Committee on Nuclear and Alternative Energy Systems (CONAES), Energy in Transition, 1985-2010, December 25, 1979. This was delivered to the Secretary of Energy on this date, copyrighted in 1980, and published in 1982.}

Although not submitted to DOE Secretary Duncan until December 25, 1979, the report itself notes that the TMI accident occurred late in the group's deliberations.

Footnotes below are in the original report.

On page 212, the report cites the Atomic Industrial Forum for information: 72 reactors with operating license (52,396 MWe capacity), 92 reactors with construction permits (101,148 MWe), 4 reactors with limited work authorizations $(4,112 \mathrm{MWe}), 30$ reactors on order $(35,082 \mathrm{MWe})$ for a total of 198 reactors (182,738 MWe).

Under present conditions, only about 0.6 percent of the fission energy potentially available is used. The fission of uranium-235 (235U) contributes 0.4 percent, and the fission of plutonium-239 $(239 \mathrm{Pu}) \mathrm{created}$ in the reactor contributes 0.2 percent. If the spent fuel removed from the reactor were reprocessed, and the $235 \mathrm{U}$ and $239 \mathrm{Pu}$ recycled in fuel, the use of uranium could be raised to 0.9 or 1 percent.[Page 214]

By loading uranium and plutonium into breeder reactors, and recycling the load many times through similar reactors after reprocessing, it is possible to recover perhaps 70 percent of the energy in the original uranium ore - an improvement in energy recovery by about a factor of 100 over light water reactors. This possibility not only multiplies the energy from existing resources (including existing enrichment plant tails), but permits economic recovery of energy from much less concentrated and more widely distributed uranium ores, essentially making uranium a potential source of energy for hundreds of thousands of years.[Page 214] 
In the reprocessing and refabrication of fuel essential to making effective use of resources in advanced converters or breeders on either the thorium or the uranium fuel cycle, fissile material (either $233 \mathrm{U}$ or $239 \mathrm{Pu}$ ) is separated from the spent fuel elements and is thus more readily subject to theft or illicit diversion than if it remained in the spent fuel elements. The appearance of pure plutonium or 233U in some stages of the fuel cycle presents the troubling possibility that weapons-usable material could be stolen by terrorists. Proposals have been advanced for reprocessing methods that avoid separation of plutonium in pure form. These schemes are given the generic name "coprocessing" when the plutonium is chemically mixed with its parent uranium throughout the cycle, and "Civex" when it is given the additional protection of retaining some highly radioactive fission products. Such processes are not now available and would require development.[Page 218]

A graver possibility than illicit diversion is that countries installing reprocessing plants would thereby have the means to build up arsenals of nuclear weapons in short order. This concern is particularly acute for breeder reactors, which have little or no value without reprocessing, and it was this consideration that persuaded the Carter administration to defer both commercial reprocessing and commitment to the fast breeder.[Page 218]

A possible advantage of the thorium-233U fuel cycle for fast breeders or advanced converters (it can be used in either) is that the $233 \mathrm{U}$ or $235 \mathrm{U}$ used to feed these reactors can be diluted with $238 \mathrm{U}$ in a $4: 1$ ratio (for $235 \mathrm{U}$ ) or a 7:1 ratio (for $233 \mathrm{U}$ ), making either undesirable as weapons material without physical isotope separation as well as chemical reprocessing. This is the "denatured" thorium cycle. The efficacy of denaturing is now the subject of extensive debate. It is being studied in the United States and will be studied further in the ongoing program of the International Nuclear Fuel Cycle Evaluation (INFCE). [Page $218]$

There was general agreement that the greatest threat of nuclear technology lies in existing stockpiles of nuclear weapons and weapons material throughout the world. There was further agreement that to the extent that high enrichment of $235 \mathrm{U}$ and isolation of $233 \mathrm{U}$ and plutonium are needed for a civilian nuclear power industry, these steps of the fuel cycle should be conducted in secured plants, preferably under international control. However, some members of the committee believe that the economic importance of nuclear energy is not great enough to warrant accepting significantly increased risk of international proliferation or subnational use of nuclear weapons, and that such increased risk will attend the spread and growth of nuclear power if these should occur more rapidly than improvements can be made in existing safeguards and deterrents. Other members of the committee believe that the world's energy problems already pose a greater long-term threat than does proliferation, and that the benefits of the rapid spread of nuclear power in alleviating these problems outweigh any plausible increase in the risks of proliferation and diversion. ${ }^{t}$ Divergent opinions on what steps to take follow from these beliefs.[Page 219]

Some argue that international solutions such as the Non-Proliferation Treaty, safeguards (monitoring by the International Atomic Energy Agency), and strengthened controls on fuel cycles can only be effected if the United States is an active participant, a reliable supplier of nuclear materials and know-how. These are arguments for carrying forward, and very probably exploiting, the development of reprocessing and breeder reactors, since both increase our ability to provide nuclear fuel.[Page 219]

Others argue that the current policy of the United States - staying the commercialization of reprocessing for the time being and limiting the development of breeders to technology-level studies - is essential as an example to others." They maintain that this forbearance is necessary to avoid a situation in which

t. [footnote in original] See statement 5-8, by E. J. Gornowski, Appendix A.

u. [footnote in original] Statement 5-9, by E. J. Gornowski: The United States has lost this argument. Reprocessing is going ahead in other countries regardless of the U.S. position. 
countries that have legitimate domestic needs for major nuclear power enterprises are tempted to manufacture nuclear weapons. The argument is that the moral position of the United States is strengthened in international negotiations by what may be some self-sacrifice.[Page 219]

The issues of diversion and proliferation make the future of reprocessing and the breeder reactor uncertain. As a consequence, the future of nuclear power beyond the point of resource scarcity is also uncertain. The undecided future of reprocessing adds to uncertainty about the form of waste that must ultimately be banished from the environment. The committee cannot resolve these uncertainties, but in the recommendations that follow, suggests ways they might be reduced by improving the reliability of information, by narrowing and clarifying areas of dispute, and by instituting interim programs that preserve flexibility of response in anticipation of better information. [Page 220]

The problem of diversion of nuclear materials by terrorist or criminal groups, and the related question of the vulnerability of nuclear facilities to sabotage, are serious matters. Domestic security measures, such as those practiced in laboratories and facilities handling enriched materials, can be effective. However, if our society moves in the direction of turbulence and polarization, questions might be raised about our ability to carry out domestic security measures properly.[Page 222]

The proliferation threat must be viewed from the perspective that the overriding security problem is to avoid war; failing this, it is to avoid war between or among superpowers, and failing that, to avoid devastating nuclear exchanges among them. Nuclear power can reduce this threat by reducing the competition for scarce resources, one of the causes of war. Nuclear power can also increase this threat by facilitating the acquisition of nuclear weapons, particularly by countries whose possession or use of them might catalyze superpower war.[Page 222]

Nuclear power is not the most likely route countries with the will to acquire nuclear armaments might follow, but it is not an impossible one. The most likely scenario by which nuclear power could contribute to nuclear armament is the appropriation of plutonium or ${ }_{233} \mathrm{U}$ from nuclear fuel cycles by a country that might not, in the absence of this opportunity, have made the decision to acquire nuclear weapons. [Page 222]

Advanced reactor types should be developed to the point that they can be evaluated for possible introduction, if needed. Three advanced reactor types can be considered: the liquid-metal fast breeder reactor, the high-temperature gas-cooled reactor, and advanced versions of heavy water reactors. Of these, the LMFBR would be recommended if industrial economic factors were the only consideration. The LMFBR has the best chance of providing insurance that a nuclear industry could in the long term meet any electrical demands that might eventuate. $\dagger$ A major consideration is, of course, the question whether the fuel reprocessing necessary to operate LMFBR's (and eventually, other advanced converters) is compatible with national antiproliferation objectives. We recommend that development of proliferationresistant reprocessing for LMFBR's proceed, pending a decision whether such methods as coprocessing, Civex, or radioactive spiking are sufficient or necessary to counter this policy objection to the LMFBR.[Page 223]

High-level and transuranic wastes from the nuclear industry should be disposed of by emplacement in a geological repository. The responsibility for site selection must ultimately rest with the federal government, as the benefits from a well-chosen repository accrue to the nation as a whole, and the risks to local populations are not high. The target for placing a first repository in operation should be the mid1990s. In the interim, spent-fuel storage should be practiced without assuming or precluding reprocessing.[Page 224]

Radioactive wastes from weapons-material production facilities, military propulsion reactors, weapons fabrication facilities, and other military activities must be dealt with independently. These wastes exist in quantity and in less-than-ideal form for geological disposal. They should, at minimum, be immobilized 
and collected at a few isolated sites. After these steps, they can be prepared for geological disposal (probably at the same sites). Within the category of defense wastes, the transuranic waste and (possibly) the high-level waste from propulsion-reactor reprocessing are the only types that can be considered for disposal at the Waste Isolation Pilot Plant near Carlsbad, New Mexico.[Page 224]

Finally, what can we say about the problem of nuclear weapons proliferation that is not a homily or a statement of alternatives? It should be continued national policy to search for ways to avoid nuclear war, but it is by no means clear that this country is prepared to give up the option of nuclear weapons for use in extreme circumstances. In this quandary, any technical or industrial policy steps are, at best, supportive of larger national policy. All the antiproliferation measures we can conceive have an experimental character, including such relatively recent measures as the deferral of domestic plans for reprocessing and breeder reactors. If they promote a more peaceful and prosperous world (and thus, necessarily, a more peaceful and prosperous United States), such policies warrant continuation and can be used as the foundations for far-reaching policies. If they do not promote these ends, they should be firmly and quietly scrapped. In the committee's view, therefore, the country should recognize that any antiproliferation measures (Civex, no reprocessing, or whatever) are not ends in themselves, but only practical measures in the service of policy decisions.[Page 225]

The relative roles advanced converters and breeders might play in the energy supply sector cannot easily be predicted. Conditions that have a reasonable chance of eventuating would be favorable to the installation of both types of reactors (steady growth in electrical demand; economic attractiveness of nuclear power relative to other sources of electricity; and satisfactory resolution of the political and social issues discussed later in this chapter).[Page 258]

Breeders are more flexible in their ability to respond to quite rapid growth in demand as well as to rather moderate growth. Thus, although the two types of reactors both serve, in a sense, as insurance that increased supplies of electricity could be provided if needed, breeders provide broader coverage. The probability that such coverage will be needed by, say, 2010 may not be very high. However, the risk of inadequate supply could be high, and insurance is of greatest value against high-risk, low-probability events. [Page 258]

Advanced converters offer insurance against moderate growth in demand for electricity, compared to past experience, and limited supplies of uranium, so long as they are not expensive. Advanced converters would also be a useful adjunct to breeders in a breeder economy. Thus, conditions favorable to their development are also flexible. ${ }^{\mathrm{y}}$ [Page 258]

CONAES concludes that these considerations lead to the recommendation that both types of reactors should be developed. If only one type can be developed, breeders should receive priority, as covering more contingencies. If, for whatever reasons, development of the breeder is so long deferred as to preclude the option of commercialization in the early twenty-first century, the commitment should be made to expeditious development of the advanced converter. [Page 258]

The committee recommends the following course of action.[Page 258]

- Development of the LMFBR should continue, but without immediate commitment to construction of prototype reactors. CONAES was divided on the issue of whether to recommend construction of the Clinch River breeder reactor as part of this development program.

- A majority of the committee considered the Clinch River breeder inappropriateness of its design as a developmental facility, ${ }^{\mathrm{w}}$ its incompatibility with President Carter's antiproliferation policies,

v. [footnote in original] See statement 5-17, by L. F. Lischer, Appendix A.

w . [foothote in original] See statement 5-18, by L. F. Lischer, Appendix A. 
and its possible contribution toward committing the United States to commercialization of the LMFBR. A minority considered it necessary, as a technological step that is well short of commitment to commercialization, but necessary if early commercialization turned out to be desirable.

- A reference design should be produced for a commercial-scale LMFBR to identify the problems that require solution in the research program.

- Commercial-scale experiments should be conducted to ensure that a workable fuel cycle for the LMFBR can be operated. ${ }^{\mathrm{X}}$ Proliferation-resistant schemes, such as the proposed Civex cycle or the denatured Th-U cycle, should receive particular attention.

- Development of the HTGR to full commercial scale should be encouraged (either the prismatic or pebblebed version).

- A pioneer-scale reprocessing plant (a few hundred tons per year) for Th-U fuels should be built and operated. Further work on recycle of HTGR fuels in such a plant should be supported, and increased attention should be given to off-gas problems and to the special requirements of coatedparticle composites.

- A joint program should be undertaken with Canada to explore and, if attractive, develop toward commercialization an advanced heavy water reactor design that can be adapted to the regulatory and economic climates of both countries. Such a design should be considered as the next major improvement of the heavy water line.[Page 258-259]

Other aspects of the public appraisal of nuclear power are principally social. They reflect differing perceptions of desirable future conditions.

- Nuclear power has become the most visible symbol of large-scale centralized technology for which many citizens feel they have surrendered control to experts who cannot be held accountable.

- A significant number of citizens dislike nuclear power, particularly the breeder, because if offers the continuation of a high-growth materialistic society that, in their view, will eventually prove disastrous to the physical and social environment of mankind.

- Some see nuclear power as competing for capital with other energy systems that are more nearly autonomous and under local control, and therefore, both in itself and as a symbol, as excluding social organizational patterns that are based on such autonomy.[See, for example, the report of the Consumption, Location, and Occupational Patterns Resource Group of this study; and Amory B.Lovins, Soft Energy Paths: Toward a Durable Peace (New York: Ballantine Books, 1977).]

- On the other hand, some see nuclear power as essential if people are to have sufficient energy to live with dignity, achieve their aspirations, and improve their own lives and those of their children. [National Association for the Advancement of Colored People (NAACP), Report of the NAACP National Energy Conference, (Washington, D.C.: NAACP, December 21, 1977).]

- Many people feel that institutions, including utilities, government, and regulatory bodies, exist to provide services to citizens; that they can and should be economical (whether large or small); and that technologies, including nuclear power, can be controlled to serve man in a safe, environmentally acceptable way.[Page 262]

$\mathrm{x}$. [footnote in original] Statement 5-19, by J. P. Holdren: The concept of a "commercial-scale experiment" is vague. If it means building a commercial-size plant for fast reactor fuel, I oppose it. 


\subsubsection{International Nuclear Fuel Cycle Evaluation, INFCE/CP/2/9, January 1980. (Summary and 8 working group reports)}

The terms of fast reactors, breeder reactors, and fast breeder reactor appear to have been used interchangeably. Note that they claim that no country with spent fuel had selected the no-reprocessing decision.

Storage and transport of spent fuel. Based up on the analysis performed by the Working Group 6, it is possible to identify four basic spent fuel management concepts:

- Decision to reprocess concept;

- Deferred decision concept;

- Fuel transfer decision concept;

- No-reprocessing decision concept.

No country with spent nuclear fuel arisings has selected the last concept mentioned.

National interpretations of spent fuel management concepts are depend on current social, economic, regulatory and political conditions and energy needs prevailing in a country at a given time. However, the national policies of one country can have an impact on other countries.

The storage of spent fuel is an interim step only, which provides flexibility in the selection and use of future fuel cycle operations. All the technical and economic factors have to be taken into consideration when calculating the optimum storage times prior to reprocessing or disposal and therefore there are no further technical or economic incentives to store beyond these optimum times.

Working Group 4 considered the economics of once-through and plutonium-recycle HWRs and LWRs and of FBRs. It also analysed some of the main economic parameters that might affect the choice between LWR once-through, LWR with plutonium recycle and FBR fuel cycles. It concluded that no one fuel cycle can be said to have an economic advantage in all cases. Each of the three cycles considered may have an economic advantage over the others in certain specific ranges of the basic parameters.

(a) Some countries plan to establish or keep open the option of thermal reactor recycle, but the economic incentive to use thermal recycle on a large scale will decrease if the price of uranium remains low and supplies are available; or if the price of uranium grows so rapidly and/or the cost of fast reactors fall so rapidly that fast reactors become more attractive than thermal reactor recycle; of if advanced thermal reactors offering improved uranium utilization become attractive.

(b) Some countries plan to establish or keep open the option of fast reactors and their fuel cycle, but the economic incentive to use them on a large scale will decrease if the price of uranium remains low and supplies are available' or if the capital and fast recycle costs of fast reactors are too high.

(c) Some countries plan to use the once-through fuel cycle for the foreseeable future, but the economic incentive to use it will decrease if the price of uranium to the country concerned grows rapidly or supplies of uranium are unobtainable or uncertain for some other reason; of if the cost of spent fuel storage, conditioning and disposal relative to the cost of reprocessing and the disposal of conditioned waste is too high.

Reprocessing in itself is important because it is an essential preliminary to many of the possible fuel cycles. The economic arguments for reprocessing depend on the price of uranium and the subsequent use that is made of the separated plutonium and uranium. If it is recycled in light water reactors, then the 
economic advantage is not likely to be large. However, some countries nevertheless see it as a positive contribution to energy independence and assurance of supply. On the other hand, if the capital costs and the fuel cycle costs of fast reactors can be brought down sufficiently, then the economic and assurance of supply advantages of fast reactor recycle could be considerable. Most countries planning to use plutonium therefore consider mainly its use in fast reactors. From the narrow micro-economic viewpoint, recycle in LWRs may be regarded as a relatively marginal matter that might be valuable for an interim period until fast reactors are introduced; on the other hand, the importance of thermal reactor recycle to some countries may not be wholly reflected in micro-economic terms.

The construction and planned misuse of fuel cycle facilities is not the easiest nor the most efficient route to acquire materials for the manufacture of nuclear weapons. However, if facilities handling a significant amount of weapons-usable materials are already established, there misuse might well, in some circumstances, be a feasible path to obtaining materials for nuclear weapons. In addition, the technology and know-how acquired in nuclear power programs, though not directly related, could be drawn on for a subsequent nuclear weapons programme. To that extent, the possibility of misuse of such materials, technology and facility entails a proliferation risk, which must be balanced against any economic, environmental, energy strategy and resource utilization advantage they may have.

The extent to which the possibilities of misuse vary as between fuel cycles is not easy to judge. Taking into account the qualitative nature of the evaluation, the different stages of development of the various fuel cycles, the extent which complete fuel cycles are present within individual countries and the evolutionary nature of the technical safeguards and institutional improvements that may be implemented, no single judgement about the risk of division from the different cycles can be made that is valid both now and for the future. Therefore this range of possible judgements on proliferation risks must be taken into account when the different arguments (including economics, safety, energy strategy, and proliferation risk) are weighted by national authorities in deciding on whether to introduce a particular fuel cycle. In general, it has seemed more important and constructive to identify those points in the nuclear fuel cycles that are sensitive from the point of view of proliferation, taking into account that a number of technical and institutional measures have been proposed or are under development that could reduce the risk of proliferation from all fuel cycles.

The risks of division identified by the working groups on this basis are associated with: fresh fuel containing enriched uranium or plutonium; uranium enrichment; reactors; spent fuel storage; reprocessing, including plutonium storage and mixed oxide fuel fabrication; and spent fuel or waste disposal. Transportation was considered as involving primarily risks of theft, which, as noted, is a matter of national responsibility. But it was also pointed out by Working Group 4 that one possible scenario for misuse of fuel cycle facilities would be a theft simulated by a national government.

The term "medium-enriched" refers to less than $20 \%$ U235.

As for the closed thorium cycles, it was recognized that they require considerably higher uranium enrichment levels than the U/Pu cycles and that less separative work would be required to produce highly enriched uranium from the denatured uranium/thorium fuel than from the low-enriched uranium. On the other hand, in the denatured uranium/thorium cycles, no directly weapons-usable material is present during transportation and storage of the fabricated fuel. Those thorium-based fuel cycles that require highly enriched uranium show a particularly important need for appropriate safeguarding systems associated with the enrichment, storage, transportation and fabrication stages.

The use of commercial-grade plutonium is an unattractive route to the manufacture of nuclear weapons as compared with the weapons-grade plutonium produced by a dedicated programme. It is considered therefore that a given amount of plutonium-239, whatever use it is prepared for, is a more serious proliferation risk than an equal amount of commercial-grade plutonium, but this cannot be quantified 
without a detailed knowledge of weapon design, which INFCE does not have. However, it should be noted that the United States government has declared that commercial-grade plutonium can be used for weapon purposes and that this statement has not been challenged by other nuclear-weapon states. From the outset, the IAEA has safeguarded plutonium as a special nuclear material without distinction as to its isotopic content.

Although in some deployment modes there could be an advantage in the use of denatured fuel (U233 and U238), it was noted that the proliferation potential of thorium fuel cycles operating with recycle of U233, with or without plutonium, is similar to that of the uranium fuel cycle operating with recycle of plutonium.

The report identified ways to reduce risk: co-location, co-conversion ("production of mixed oxide from mixed uranium and plutonium solutions ... pure plutonium no longer exists in the fuel cycle"), storage and transport of plutonium as mixed oxide, co-processing ("modification of reprocessing in which plutonium does not exist in separate form but emerges from the reprocessing plant in a mixed stream of uranium and plutonium nitrate suitable for co-conversion"), denaturing (for U233), pre-irradiation (at fabrication site, before transport to reactor), spiking, partial processing ("a modification of reprocessing in which fission products that are radioactive are not completely separated from the plutonium").

\subsubsection{GAO, "Nuclear Fuel Reprocessing and the Problems of Safeguarding Against the Spread of Nuclear Weapons," report EMD-80-38, March 18, 1980.}

Adequate safeguards to prevent the theft or diversion of weapons-usable material from commercial nuclear fuel reprocessing plants have not yet been developed. Recognizing the risks of nuclear technology and/or materials being diverted from such plants, the President decided in 1977 to indefinitely defer commercial nuclear spent fuel reprocessing in the United States.

The President justified this decision on the basis that the United States can sustain its nuclear power program for the foreseeable future without reprocessing and that premature commercialization of reprocessing in the United States could encourage other nations to expand reprocessing activities. In spite of the U.S. policy, many other countries continue to expand their reprocessing programs.

GAO concluded that the administration's policy has hampered research and development of ways to safeguard against the diversion of nuclear material from reprocessing plants for nonpeaceful purposes.

\subsubsection{NASAP (Nonproliferation Alternative Systems Assessment Program). 1980. "Nuclear Proliferation and Civilian Nuclear Power, Report of the Nonproliferation Alternative Systems Assessment Program," report DOE/NE-001, Executive Summary, volumes I to IX, June 1980.}

While today's most widely used system does not readily lend itself to the proliferation of nuclearweapons (or nuclear-explosive) capabilities, it may nonetheless facilitate the acquisition of the materials, facilities and expertise necessary to develop nuclear weapons. This system involves mining and milling uranium ore, enriching uranium to a concentration of about 3 to 5 percent in the fissile U235 isotope, fabricating the enriched uranium into reactor fuel elements, using this fuel in the light-water reactor in a "once-through" mode, that is, using it to generate power than then discharging the spent fuel into interim storage (also called "stow-away"), without deciding whether to put it into long-term storage or dispose of it permanently. It should be noted that spent fuel from interim storage could alter be used in a closed fuel cycle - that is, reprocess to recover uranium and plutonium for re-use ("recycle") in nuclear power reactors. 
While concern about the relationship between civilian nuclear power and research programs and the proliferation of nuclear weapons is not new, international attention to this problem has increased in recent years. There are a number of reasons for this heightened concern, including in particular the Indian nuclear explosion of 1974, which involved material and facilities supplied for peaceful purposes. In this new atmosphere, the United States has introduced important adjustments in its nonproliferation policy, while continuing to stress the importance of previous efforts in this area such as the Treaty on the NonProliferation of Nuclear Weapons (commonly known as the Non-Proliferation Treaty) and the International Atomic Energy Agency (IAEA) safeguards system. These policy adjustments in large part reflect the fact that an increasing number of nations either already posses or plan to acquire nuclear fuelcycle facilities that produce or can be used to produce weapons-usable plutonium or uranium. While recognizing that political and security incentives remain central to the problem of proliferation, U.S. policy now gives increased emphasis to the risks of proliferation through the fuel cycle, and the commitant need for restraint in moves toward a nuclear-economy that would involve ready access to weapons-usable materials and the facilities to produce them. On April 7, 1977, President Carter issued a Nuclear Power Policy Statement that contained several initiatives designed to bring U.S. nuclear policy into line with this new emphasis.

This policy deferred commercial reprocessing, delayed commercializing the fast breeder reactor, and restructured the fast-breeder program to give greater priority to alternative designs and accelerated research into alternative fuel cycles.

The author notes that parameters considered in NASAP found their way into later US and international proliferation assessment approaches, e.g., Resources required, Time required, and Risks of detection.

The most important conclusions of the NASAP proliferation-resistance assessment are:

1. All nuclear fuel cycles would entail some proliferation risks; there is no technical "fix". Nevertheless, the light-water reactor fuel cycle with spent fuel discharged to interim storage does not involve weapons-usable material in any part of the fuel cycle and is a more proliferationresistant nuclear power fuel cycle than other fuel cycles which involve highly enriched uranium or pure plutonium.

This may be the most important paragraph in the report. Remember that NASAP did not set policy or regulation; it was technical analysis. Thus, although this is the first explicit mention found to "pure plutonium" as opposed to merely "plutonium", that (by itself) has no policy impact. The first sentence of the above paragraph is often cited, but not the second. The second has the effect of somewhat equating HEU and "pure plutonium" from the proliferation-resistance standpoint. The converse of the second sentence is not stated, i.e., how do impure plutonium and once-through compare?

2. There would also be substantial differences in proliferation resistance among the fuel cycles if they were to be deployed in non-nuclear-weapons states. Some of these differences would be technical in nature (e.g., no reprocessing in once-through fuel cycles as compared to closed fuel cycles involving reprocessing), and some would result from institutional arrangements (e.g., the limited deployment of existing international enrichment services).

No nuclear fuel cycle which could be commercially deployed in the next few decades would offer more proliferation resistance than that associated with a light-water reactor once-through fuel cycle, in which spent fuel is safeguarded in interim storage facilities and enrichment services are provided by the existing suppliers. Although plutonium might be separated from stored spent fuel, the process would require the same reprocessing technology during the first $100-150$ years of storage. 
Under any realistic deployment schedule for the foreseeable future, the amount of plutonium and the rate of its increase would not be likely to differ very much no matter which fuel cycle was adopted. However, fuel cycles differ greatly in the form in which plutonium appears. The recycle system involves the production and processing of separated plutonium in reprocessing and fabrication facilities, and its presence in storage and transit. While these same difficulties apply in principle to fast-breeder fuel cycles, major fast-breeder programs are expected to remain confined for several decades to a few nations. The spread of breeder reactor research and development activities however, continues to be an area of concern.

3. Technical and institutional proliferation-resistance features can help. With the progressive introduction of such features, the proliferation-resistance differences among fuel cycles might be much smaller by the time they eventually came into widespread use. Such measures for the near term, when few recycle or fast breeder systems will be commercialized, and those for different fuel-cycle development choices, can be summarized as follows: wider acceptance of international safeguards on all civilian nuclear activities (full-scope safeguards) and of the Non-Proliferation Treaty and other treaties (e.g., Treaty of Tlatelolco); development of effective safeguards; continued reliance on existing suppliers of enrichment services, including ventures under international or multi-national auspices rather than undertaking new research and development in the absence of a clear demonstration of need; and adherence to explore controls and the present suppliers' guidelines.

Additional measures are: cooperative arrangements to ensure adequate spent-fuel storage and to provide for interim storage; development of mechanisms for the international management or supervision of stocks of separated plutonium; arrangements to minimize or avoid the storage or transport of undiluted plutonium; cooperative arrangements to share the use of existing large research reactors and critical facilities, and similarly to provide opportunities for research and development on breeder reactors under international or multinational auspices when the need is clear. Finally, it is important to limit the use of materials in research reactors to enrichment levels which minimize the presence of weapons-usable materials.

4. The vulnerability to threats by subnational groups varies among fuel cycles. Recycle systems would be vulnerable to a wide range of threats, whereas current once-through fuel cycles are susceptible to only the most sophisticated threats.

Technical modifications have been suggested as one means of reducing the proliferation risks associated with certain aspects of the nuclear fuel cycle, particularly that part of the fuel cycle containing plutonium. Such measures

In response to comments, the executive summary adds ...

Fuel cycles which involve pure plutonium or highly enriched uranium, both weapons-usable materials, are potentially vulnerable to a wide range of subnational threats. On the other hand, once-through fuel cycles are potentially vulnerable only to more sophisticated threats because a substantial effort would be needed to acquire and process the highly radioactive spent fuel to obtain weapons-usable material.

The report does not attempt to quantify proliferation-resistance benefits in terms of how U.S. initiatives could affect the nuclear power programs of others. Rather, the NASAP report states that the intent of U.S. Administration initiatives on reprocessing and breeder development was to domestic civilian nuclear power policy into line with international policy. The international policy in question was based on the premise that plutonium fuel cycles pose unique proliferation risks and that their accelerated deployment, particularly for thermal recycle, would yield only marginal benefits from an economic viewpoint. 
The Administration did not state that stopping reprocessing would stop proliferation. However, the Administration felt that it would have been clearly inconsistent to have warned against the risks of plutonium fuel cycles, on one hand, and, on the other, to advance toward early commercial deployment of the breeder reactor.

The following paragraph avoids both extreme positions - proliferation is totally institutional or totally technical.

The problem of proliferation, like all major national and international problems, is too complex to be solved by a single approach, technical or institutional. The NASAP report states that although the problem cannot be solved by technical means, it can be mitigated by technical means. It further states that technical and institutional approaches to the problem are related, though in diverse and complex ways from one fuel cycle to another, and that the combination of technical means and institutional arrangements can enhance the proliferation resistance of nuclear power systems. On the basis of different interrelationships between technical and institutional approaches, the NASAP report states that particular realizations of nuclear power systems should be analyzed and various alternatives examined in relation to technical and institutional considerations. It recognizes that differences between nuclear power systems are likely to require different technical and institutional measures to improve their proliferation resistance.

\section{Volume 2 focuses on proliferation resistance assessments.}

The assessments of the proliferation resistance of various fuel cycles involve the simultaneous consideration of many variables, most of them unquantifiable, and an awareness of the evolutionary nature of the fuel cycles and the evolutionary nature of nuclear programs in different countries. Accordingly, these assessments cannot be purely technical in nature, nor is there a proliferation resistance "index" that can be applied. For instance, it has not been found useful to try to rank the three generic fuel cycles or their respective reference systems and alternatives quantitatively. Rather, what has been done has been to identify promising combinations of fuel cycles, and technical and institutional improvements for current fuel-cycle activities and deployments.

The most importance conclusions of the NASAP proliferation resistance assessments are:

- All nuclear fuel cycles entail some proliferation risks; there is no technical "fix" that will permit operation of a nuclear-power fuel cycle with material that cannot be diverted to use in nuclear weapons or that will preclude a determined owner-operator from designing a proliferation strategy.

- The LWR fuel cycle with spent fuel discharged to interim storage, however, does not involve directly weapons-usable material in any part of the fuel cycle and is a more proliferation-resistant nuclear-power fuel cycle than other fuel cycles which involve work with HEU or pure plutonium.

- Substantial differences in proliferation resistance also exist between the fuel cycles if they are deployed in NNWS's. Some of these differences are technical in nature (e.g., no reprocessing in once-through fuel cycles), and some result from institutional arrangements (e.g., limited deployment of existing international enrichment services).

- On the other hand, with progressive introduction of technical and institutional measures to improve proliferation resistance, these differences may be reduced by the time the fuel cycles eventually come into widespread use. The differences will remain until the necessary improvements have been made, not only in newer facilities, but also in older ones. 
- The vulnerability to threats by subnational groups varies between fuel cycles' whereas oncethrough fuel cycles are susceptible to only the most sophisticated threats; closed fuel cycles are vulnerable to a wide range of threats.

The bullet above does not necessarily mean what it might be taken to mean today because later the report seems to equate "closed fuel cycles" with "plutonium in weapons-usable form"...

- Given the current relative availability of detailed process information and trained personnel, the isotopic barrier to the production of weapons-usable material from fresh fuel appears greater than the chemical or radiation barrier to the production of weapons-usable material from spent fuel. But this difference could change with time, particularly if enrichment facilities become widespread.

- The LWR fuel cycle with spent fuel discharged to storage has relatively high barriers to proliferation at this time, but it does have vulnerabilities. The two greatest proliferation risks would arise:

- If the potential proliferator had an enrichment plant, or, since enrichment services are now supplied by only a few nations,

- If the potential proliferator had an out-of-system reprocessing facility to recover weapons-usable plutonium from spent fuel.

- Facilities for closed fuel cycles potentially increase proliferation risk because plutonium would appear in weapons-usable form and in forms that are relatively easy to exploit for weapons purposes. Without deployment constraints and suitable institutional arrangements, plutonium would appear in substantial and widespread inventories in bulk forms, which are inherently difficult to safeguard.

The only specific non-PUREX process specifically evaluated for proliferation resistance appears to be what we now call electrochemical. Indeed, in chapter 2 of volume II, the reference closed system for LWRs is PUREX and MOX fuel. The reference closed system for fast breeders is oxide fuel and PUREX; pyrometallurgy and metal fuel are "alternative fast breeders." Even in the fast-breeder section of volume $I I$, recycle of $P u$ and $U$ is discussed; minor actinides are not mentioned.

A reprocessing technique that cannot be used directly or cannot be modified readily to produce separated plutonium has not been demonstrated. Prospective techniques like pyrometallurgy have been provisionally identified on the basis of preliminary analysis as possibly offering greater diversion resistance for reprocessing fast-breeder fuels.

The pure versus impure or diluted plutonium issue is addressed to some degree in the following:

Realizations of a plutonium-based fuel cycle in which the nation concerned restricts itself to the deployment of the reactor alone and relies upon reprocessing or fabrication services supplied from a few large facilities are significantly less vulnerable to the risk of proliferation. However, the form of the plutonium and the conditions under which it is returned to the country are important.

- An arrangement to minimize or avoid bulk materials, either plutonium metal, plutonium oxide, or mixed oxides (MOX) of uranium (UO2) and plutonium (PUO2), in storage or transit would be a significant improvement.

- The addition of a radiation barrier may increase somewhat the time and additional out-of-system facilities required to produce weapons-usable material so that an international response can be development. 
- Placing these few large facilities under some form of international or multinational arrangement could also be helpful in reducing proliferation risks.

In the case of realizations in which all the nuclear facilities are deployed within a nation, none of the technical alternatives, including radiation barriers, can be very effective in presenting abuse, particularly with regard to overt diversion. Engineering features to reduce accessibility to plutonium and to facilitate safeguards may be helpful in reading the risks of covert diversion. In addition, agreeing to minimize or avoid significant quantities of undiluted plutonium in any form in any part of the fuel cycle could provide an indication that a country stood in violation of it should undiluted plutonium be found.

Resistance to subnational theft can be improved by the introduction of appropriate combinations of collocation of sensitive facilities, co-conversion, coprocessing, pre-irradiation, spiking, or partial processing, and engineering features to reduce accessibility to plutonium.

The appropriateness of radiation barriers against a subnational group will depend largely on their effect on safeguards and physical protection, and economic and environmental considerations.

The improvements contemplated in international safeguards, including improved plutonium management schemes, will also make subnational theft more difficult.

\section{The radiation barrier is directly addressed:}

It has also been suggested that special nuclear materials (SNM) can be "downgraded" to inhibit use in nuclear weapons by enhancing the emission rate of alpha particles, gamma rays, neutrons, or heat. Judgments about the use of SNM must depend on a detailed knowledge of nuclear-weapons design and testing. Although producing such details would conflict with U.S. nonproliferation policies, three conclusions can be drawn:

- $\mathrm{U}-233$ is, in principle, as weapons-usable as U-235 or plutonium.

- Increasing the emission rate of neutrons in U-233, U-235, or Pu would not preclude their use in weapons. This conclusion also applies to the presence of $\mathrm{Pu}-238$.

- The presence of U-232 in U-233 does not provide effective protection against misuse.

The basic fissile fuel material for the recycle reactor is plutonium. Isotopic dilution cannot render this material unusable for weapons in the way that diluting U-233 or U-235 with U-238 does in once-through systems. Heat spiking of plutonium with $\mathrm{Pu}-238$ would pose an isotopic barrier to its separation. Separation would not be necessary, however, since the heating problem can be easily overcome. Consequently, technical nonproliferation measures for plutonium center on chemical dilution and the provision of a radioactive barrier by radioactive contamination.

Radioactive contamination may be effected either by adding radioactive materials such as cobalt-60 (Co60 ) to the plutonium after reprocessing (spiking) or by permitting a portion of the fission products from the spent fuel to remain with the plutonium during reprocessing (partial decontamination). Alternatively, the fuel may be irradiated before leaving the reprocessing/fabrication complex (pre-irradiation). The purpose of such process alterations would be to afford a protective radiation barrier to plutonium-bearing materials, including the fresh fuel. The radiation fields can be substantial and, although not as high as those from spent fuel, can require special handling and remote hot-chemical reprocessing to recover weapons-usable material. Radiation levels on the order of tens to a hundred rem/hr at 1 meter have been judged sufficient to force a nation seeking to produce tens of weapons to conduct reprocessing in a hot facility. This protection would correspond to that of spent fuel 100 to 150 years after discharge from a reactor. 
Dilution with uranium may be effected by either by coprocessing or co-conversion. Radioactive contamination may be effective by either spiking or partial decontamination (alternatively, a radiation barrier could be introduced by pre-irradiating the fuel). Other technical measures including passive engineered features to reduce accessibility, active denial features, and perhaps integral separation and fabrication facilities. To obtain pure plutonium would require changes in some cases to the process itself, and in some cases to the process equipment, in some cases to the facility, and in some cases to all three. The activities required in cases where changes in the chemical process are involved can be characterized by the times and efforts needed to prepare for the changes and to carry them out. These times and efforts are summarized in Table 3.3-2.

Table 6 of report. Table 3.3-2. Characteristics of Activities Required for Plutonium Production from Different Separation and Reprocessing Schemes.

\begin{tabular}{|l|l|l|l|l|}
\hline \multicolumn{1}{|c|}{ Technology } & $\begin{array}{l}\text { Time/Resources to } \\
\text { Plan and Develop } \\
\text { Changes for Pure } \\
\text { Pu }\end{array}$ & \multicolumn{1}{|c|}{$\begin{array}{c}\text { Time/Effort to } \\
\text { Install Changes }\end{array}$} & $\begin{array}{c}\text { Time to Produce } \\
\text { Pure Pu }\end{array}$ & \multicolumn{1}{|c|}{ Comments } \\
\hline Normal PUREX & None & None & None & Standard process \\
\hline Co-conversion & None & None & None & $\begin{array}{l}\text { Separated Pu is } \\
\text { present in the } \\
\text { process }\end{array}$ \\
\hline Coprocessing & Weeks/low & Days/minor & Days & \\
\hline $\begin{array}{l}\text { Partial } \\
\text { decontamination }\end{array}$ & Weeks/low & Days/minor & Days & \\
\hline Spiking & Little or none & Little or none & Little or none & \\
\hline $\begin{array}{l}\text { Pyrometallurgy } \\
\text { (zinc distillation) }\end{array}$ & Months/substantial & Months/major & Weeks & $\begin{array}{l}\text { Process requires } \\
\text { substantial } \\
\text { technology } \\
\text { development }\end{array}$ \\
\hline
\end{tabular}

All schemes except the last listed in the table are based on the aqueous PUREX process and could be used to produce variations of the oxide fuels of the reference recycle and breeder fuel cycles. The pyrometallurgy process would be used for metallic fuels, depends on technology to be developed, and would probably be considered for application only to alternative fast breeders.

\subsubsection{GAO, "U.S. Breeder Reactor Program Needs Direction," report EMD-80- 81, September 22, 1980.}

The LMFBR program:

- Lacks a clear mission and focus resulting in a considerable waste of time and money.

- Does not include assurance that the requisite institutional conditions for commercializing the option industrial capability and utility confidence - will be in place to allow for a smooth transition to this energy supply option if and when it is needed." [Page ii]

After three decades and several billion dollars of research and development on this energy system, DOE officials were unable to provide GAO with an approved and generally accepted plan on how to secure the LMFBR option by the year 2020 even though they recognize the need to have such a plan.[Page iii]

The Congress has continued funding the Clinch River Plant every year since 1977, despite the administration's repeated attempts to kill it. Even with continue funding, however, no work has begun on 
constructing the facility. Recent actions by the administration underscore its desire to kill the Clinch River project and to defer any commitment for a substitute plant. Specifically

-- The fiscal year 1981 budget submitted to the Congress again calls for termination of the Clinch River Plant;

-- the Nuclear Regulatory Commission licensing staff that is necessary for the Clinch River project to move toward construction has been dispersed;

-- the fiscal year 1981 budget is requesting that the Nuclear Regulatory Commission's LMFBR safety research program be terminated; a move that, according to the Commission, could cost the LMFBR program about 1 years of development time if work is ever resumed; and

-- a decision on whether to construct a substitute plant for the Clinch River facility, scheduled for March 1981, has not been supported in the administrations' fiscal year 1981 budget request. [Page iii-iv]

\subsubsection{DOE, "Final Environmental Impact Statement - Management of Commercially Generated Radioactive Wastes," DOE/EIS-0046F, October 1980.}

This EIS examined many alternatives for disposal environments and for waste forms. It focused on four "example" environments: salt, granite, shale (clay), basalt as follows:

"Disposal media of salt, granite, shale, and basalt are examined here and represent only selected sample of candidate host rock types. Other host rock types may also meet the requirements for media properties and distribution. Additional media can be grouped as having properties similar to those of the example media. Associated disposal media are grouped as 1) salt: anhydrite, gypsum; 2) granite: general crystalline rock, granodiorite; periodotite; gneiss, syenite; 3) shale: general argillaceous rock, carbonate; and 4) basalt: gabbro and some tuffs."

\section{It considered several "alternative disposal methods", as follows:}

Very Deep Hole - "A very deep hole concept has been suggested that involves the placement of nuclear waste in holes in geologic formations as much as 10,000 meters ( 6 miles) underground. Potential rock types for a repository of this kind include crystalline and sedimentary rocks located in areas of tectonic and seismic stability."

Rock Melt - "The rock melt concept for radioactive waste disposal calls for the direct placement of liquids or slurries of high-level wastes or dissolved spent fuel, with the possible addition of small quantities of other wastes, into underground cavities. After the water has evaporated, the heat from radioactive decay would melt the surrounding rock. The melted rock has been postulated to form a complex waste form by reaction with the high-level waste."

Island-based - "Island-based disposal involves the emplacement of wastes within deep stable geological formations, much as in the conventionally mined geologic disposal concept and in addition relies on a unique hydrological system associated with island geology."

Subseabed - "It has been suggested that wastes could be isolated from the biosphere by emplacement in sedimentary deposits beneath the bottom of the deep sea (thousands of meters below the surface), which have been deposited over millions of years. The deposits have been shown by laboratory experiments to have high sorptive capacity for many radionuclides that might leach from breached waste packages. The water column is not considered a barrier, however it will inhibit human intrusion and can contribute to dilution by dispersal of radionuclides that might escape the sediments." 
Ice Sheet - "Disposal in continental ice sheets has been suggested as a means of isolating high-level radioactive waste. Past studies have specifically addressed the emplacement of waste in either Antarctica or Greenland. The alleged advantages of ice sheet disposal, which are disposal in a cold, remote area and in a medium that should isolate the wastes from man for many thousands of years, cannot be proven on the basis of current knowledge."

Well injection - "Two methods of well injection have been suggested: deep well liquid injection and shale/grout injection. Deep well liquid injection involves pumping acidic liquid waste to depths of 1000 to $5000 \mathrm{~m}(3,300$ to $16,000 \mathrm{ft})$ into porous or fractured strata that are suitably isolated from the biosphere by relatively impermeable overlying strata. The waste is expected to remain in liquid form and may thus'progressively disperse and diffuse throughout the host rock. Unless limits of movement are well defined, this mobility within the porous host media formation would be of concern regarding eventual release to the biosphere. For the shale/grout infection' alternative, the shale is fractured by high-pressure injection and then:the waste, mixed with cement and clays, is injected into the fractured shale formations, at depths of 300 to $500 \mathrm{~m}$ (1000 to $1600 \mathrm{ft})$ and allowed to solidify in place in a set of thin solid disks. Shale has very low permeability and predictably good sorption properties. The formations selected for injection would be those in which it can be shown that fractures would be created parallel to the bedding planes and in which the wastes would be expected to remain within the host shale bed."

Transmutation Concept - "In the reference transmutation concept, spent fuel would be reprocessed to recover uranium and plutonium (or processed to obtain a liquid high-level waste stream in the case where uranium and plutonium are not to be recycled). The remaining high-level waste stream is partitioned into an actinide waste stream and a fission product stream. The fission product stream is concentrated, solidified, and sent to a mined geologic repository for disposal. The waste actinide stream is combined with uranium or uranium and plutonium, fabricated into fuel rods, and reinserted into a reactor."

Space - "Space disposal has been suggested as a unique option for permanently removing high-level nuclear wastes from the earth's environment. In the reference concept, high-level waste is formed into a ceramic-metal matrix, and packaged in special flight containers for insertion into a solar orbit, where it would be expected to remain for at least one million years. The National Aeronautics and Space Administration (NASA) has studied several space disposal options since the early 1970s."

\subsubsection{GAO, "Is Spent Fuel or Waste From Reprocessed Spent Fuel Simpler to Dispose Of?," report EMD-81-78, June 12, 1981.}

This is the first mention found of 50 years as the minimum period of retrievability for spent fuel in a repository. The two options are referred to as "recycle option" and "throw-away option". Note the tentative site selection dates (Basalt February 1983, Salt Dome July 1983, Bedded Salt September 1984, Tuffs November 1984, Granite June 1985.)

There are two technical changes that have occurred since 1981.

1) The comparison of unprocessed spent fuel to uranium ore shows a cross over point at $\sim 10,000$ years. My personal recollection is that it is in this time period that Np237 and other TRU's dose conversion factors were revised and I suspect that that was the cause. Indeed, the TRU other than Pu aren't even mentioned. With today's parameters, the minor actinides are known to be important. Of course, we also understand the fission products much better as well.

2) The waste package was to be given credit for 1000 years. Since then, there have been strong technical basis for long waste package lifetimes.

In developing the nuclear waste management program, the previous administration assumed that spent fuel could be as easily stored or isolated from the environment as reprocessed high-level waste. GAO does not agree with that assumption. GAO found that the form of the waste-- spent fuel or solidified high- 
level waste --will have a significant influence not only on the location, design, and possibly the number of repositories, but also on the ability of DOE to assure isolation of waste for the period of its toxicity. (See pp. 25 to 31.)[Page iii]

Based on information obtained to date, DOE contractors believe a waste package can be designed to contain either spent fuel or high-level waste for 1,000 years. Because of the extended toxic life of spent fuel, however, the geology must serve as the primary barrier between it and the environment. The waste package offers little long-term advantage in this case. High-level waste, on the other hand, decays before 1,000 years to a radioactive level less than that of naturally occurring uranium ore. Thus, the waste package offers major advantages in the disposal of high-level wastes. (See p. 32.) [Page iii]

GAO found that spent fuel does indeed create problems that make its isolation more difficult. For instance, spent fuel contains mostly long-lived radionuclides, such as plutonium and uranium, which remain toxic for hundreds of thousands of years. [Page iv]

High-level waste, on the other hand, has most of these long-lived elements removed during reprocessing, and it decays to radioactive levels of naturally occurring uranium ore in about 600 to 1,000 years. DOE believes it has the technology to fabricate a barrier system which will isolate the wastes for 1,000 years, thus removing the potential hazards of the high-level waste but not those of spent fuel. (See pp. 39 and 40.) [Page iv]

In addition, GAO found that spent fuel

-- unlike high-level waste, cannot be made into a homogeneous mixture to suit the characteristics of the repository and other parts of the waste system, which makes it more to difficult to prove the longterm integrity of the repository;

-- could require three times as much area in a repository as reprocessed high-level waste;

-- will cost more to dispose of than high-level waste, considering the value of the uranium and plutonium recovered during reprocessing;

-- is a valuable energy resource, particularly if other advanced energy technologies under development do not progress as expected; and

-- even when disposed of does not eliminate the proliferation problem but merely transfers it to future generations who might find it necessary to exhume the spent fuel for whatever purposes they consider necessary, including the manufacture of nuclear weapons.[Page iv-v]

Thus, when considering only the impact on nuclear waste disposal, it makes sense that spent fuel not be buried in a repository but instead be reprocessed to recover the valuable uranium and plutonium. Unfortunately, the solution to the reprocessing question cannot be based solely on the waste disposal issue. A much more overriding consideration is the future role that commercial nuclear power will play in this country. (See p. 40.) [Page v]

If nuclear power is intended only to serve as a stop-gap energy alternative until other advanced technologies are developed, there is no question that spent fuel will not be needed and must eventually be buried or otherwise isolated from the accessible environment. But if commercial nuclear power makes a strong comeback and fulfills the predictions from its early development, spent fuel will be a valuable resource, worth the equivalent of billions of barrels of oil. [Page v]

Unfortunately, however, the United States as a country has been ambivalent toward the future of commercial nuclear power. On the one hand, the country recognizes that nuclear power has the potential (through development of the breeder reactor and other advanced nuclear technologies) to provide all of 
our electricity needs for centuries, while on the other hand there are still concerns about the many potential or perceived safety and environmental hazards of nuclear power. (See p. 41.) [Page v]

The first geological repository under DOE's waste management program is not expected to be completed until sometime between 1997 and 2006. DOE believes this is a realistic schedule considering it must adhere to waste management guidelines provided by President Carter in February 1980. The guidelines, which were consistent with those developed by the Interagency Review Group on Nuclear Waste Management, require DOE to

-- develop concurrent information on a number of potential repository locations and geological media, before deciding where the first repository will be located;

-- design geological repositories capable of isolating both spent fuel and high-level wastes:

-- provide for the retrievability of the nuclear wastes (within the first 50 years) if that proves necessary for health and safety reasons; and

-- give State and local governments an effective role in implementing the nuclear waste management program.[Page 5-6]

Even though the first repository will not be completed for 20 years, this is the first comprehensive effort made by the Federal Government to address all the waste management issues, including those associated with the political and social concerns of the States and localities where the repositories might be located.[Page 6]

The ultimate objective is to have an operational repository between 1997 and 2006 which is capable of accepting both commercial spent fuel and defense high-level waste. DOE estimates that such a repository with its multiple barrier system will cost between $\$ 2.17$ billion to $\$ 3.95$ billion, depending upon the rock type in which the repository is to be built and the repository size.[Page 11]

ONWI is currently screening the United States, trying to identify several acceptable repository sites by 1985. While this effort is progressing in some regions, State and local jurisdictions in other regions are hampering the site-screening process. This may eventually require the Federal Government to act unilaterally without State concurrence.[Page 11]

ONWI's process for identifying potential sites has included the study of successively smaller land units. At first, regions within the United States were selected by using existing literature in scientific reports, geological maps, earthquake occurrence, and drilling records. (See next page.) The remaining steps, which have progressed to varying degrees in each region, involve some core sampling and exploratory drilling to identify areas (about 1,000 sq. miles), locations (about 30 sq. miles), and finally potential repository sites.[Page 11]

The three most important factors in this screening process are the rock type, the hydrology (water), and the past and future land uses. The rock type that has historically held the most promise and which has been studied the most extensively is salt. As far back as the 1950s, salt was identified as the leading candidate in which to build a repository. It is almost devoid of water, has existed for millions of years in stable formations, and is plentiful.[Page 11]

To date eight potential locations have been identified in either salt domes or bedded salt. In fact, some experts contend that using today's technology, a repository could be built rather quickly in one or more of the existing salt locations (assuming State concurrence and that the remaining site investigative work proved positive). Under the existing program, however, the work in salt will continue until acceptable repository sites are determined. These sites will then be "banked" or put into reserve until concurrent site selections are made in other geological mediums, such as basalt, tuffs, and granite. All the potential sites 
will then be studied and compared, with the first repository site selection scheduled for 1987 . Hopefully this site will be the best for housing a repository, both technically and politically.[Page 11-13]

Under this approach, the tentative site selection dates for each of the rock types are as follows:[Page 13]

Tentative Site

Rock Type $\quad$ Selection Date

Basalt $\quad$ February 1983

Salt Dome July 1983

Bedded Salt September 1984

Tuffs November 1984

Granite June 1985

\subsubsection{R. W. Reagan, "Statement Announcing a Series of Policy Initiatives on Nuclear Energy," October 8, 1981.}

To correct present government deficiencies and to enable nuclear power to make its essential contribution to our future energy needs, I am announcing today a series of policy initiatives:

(1) I am directing the Secretary of Energy to give immediate priority attention to recommending improvements in the nuclear regulatory and licensing process. I anticipate that the Chairman of the Nuclear Regulatory Commission will take steps to facilitate the licensing of plants under construction and those awaiting licenses. Consistent with public health and safety, we must remove unnecessary obstacles to deployment of the current generation of nuclear power reactors. The time involved to proceed from the planning stage to an operating license for new nuclear powerplants has more than doubled since the mid1970 's and is presently some $10-14$ years. This process must be streamlined, with the objective of shortening the time involved to $6-8$ years, as is typical in some other countries.

(2) I am directing that government agencies proceed with the demonstration of breeder reactor technology, including completion of the Clinch River Breeder Reactor. This is essential to ensure our preparedness for longer-term nuclear power needs.

(3) I am lifting the indefinite ban which previous administrations placed on commercial reprocessing activities in the United States. In addition, we will pursue consistent, long-term policies concerning reprocessing of spent fuel from nuclear power reactors and eliminate regulatory impediments to commercial interest in this technology, while ensuring adequate safeguards.

It is important that the private sector take the lead in developing commercial reprocessing services. Thus, I am also requesting the Director of the Office of Science and Technology Policy, working with the Secretary of Energy, to undertake a study of the feasibility of obtaining economical plutonium supplies for the Department of Energy by means of a competitive procurement. By encouraging private firms to supply fuel for the breeder program at a cost that does not exceed that of government-produced plutonium, we may be able to provide a stable market for private sector reprocessing and simultaneously reduce the funding needs of the U.S. breeder demonstration program.

(4) I am instructing the Secretary of Energy, working closely with industry and State governments, to proceed swiftly toward deployment of means of storing and disposing of commercial, high-level radioactive waste. We must take steps now to accomplish this objective and demonstrate to the public that problems associated with management of nuclear waste can be resolved. 
(5) I recognize that some of the problems besetting the nuclear option are of a deep-seated nature and may not be quickly resolved. Therefore, I am directing the Secretary of Energy and the Director of the Office of Science and Technology Policy to meet with representatives from the universities, private industry, and the utilities, and requesting them to report to me on the obstacles which stand in the way of increased use of nuclear energy and the steps needed to overcome them in order to assure the continued availability of nuclear power to meet America's future energy needs, not later than September 30, 1982.

\subsubsection{GAO, "DOE Confident It Can Fuel the Clinch River Breeder Reactor and other Breeder Reactor Projects," report EMD-82-89, May 14, 1982.}

This report indicates that DOE was confident, as late as May 1982, that it could meet plutonium needs for $C R B R$, despite Barnwell's demise. One of its options was to modify then-operating reprocessing facilities at Savannah River.

DOE is responsible for providing plutonium for national defense and DOE civilian program needs, including the needs for DOE's breeder reactor projects. DOE's Office of Nuclear Materials Production (ONRP) which is under the Assistant Secretary for Defense Programs is responsible for meeting these needs. ONMP has traditionally provided and plans to continue providing plutonium to the breeder reactor program at no cost to the breeder program. The cost for providing plutonium is included in the budget for DOE's defense programs.

ONMP plans to provide the plutonium needed for the breeder reactor projects from a combination of existing DOE inventories, reprocessed commercial reactor spent fuel, and, if needed, other sources such as purchases from foreign countries. ONWP officials, however, would not specify the exact source of plutonium for the CRBR and other breeder reactor project needs because any such discussions may reveal classified information concerning the amount of plutonium to be used for national defense needs. In this regard, ONMP officials noted that plutonium needed for national defense takes precedence over all other needs. Thus, the amount of plutonium available for the CRBR and other breeder reactor projects could vary depending on the national defense needs.

Although ONMP officials would not be specific regarding the source of plutonium for DOE's breeder reactor projects, they assured us that the plutonium will be provided for such activities. They noted that in addition to existing inventories, they have several options. For example, as discussed more fully in the following section, they are currently exploring the possibility of modifying an existing DOE fuel reprocessing facility to enable it to reprocess commercial reactor spent fuel and other spent fuel such as breeder reactor spent fuel. This proposed modification, if implemented, would increase DOE's capability for supplying plutonium. ONMP officials stated that they could also purchase plutonium from foreign sources if needed. Furthermore, they noted that as the CRBR begins operating, it will generate approximately 25 percent more plutonium than it uses, thus, providing part of its own source of plutonium.

DOE's fiscal year 1983 budget request included \$5.6 million for conceptual design efforts for modifying one of its reprocessing facilities to expand DOE's capability for supplying plutonium. DOE currently operates two fuel reprocessing facilities at Savannah River, South Carolina, and is preparing to restart a third fuel reprocessing facility at Richland, Washington, in 1984. DOE's existing reprocessing facilities produce plutonium for the defense programs by chemically dissolving the spent fuel components from DOE's plutonium production reactors and separating and recovering the plutonium and other elements from the spent fuel. DOE's existing reprocessing facilities cannot recover plutonium from commercial reactor spent fuel, spent fuel from the Fast Flux Test Facility, or the future demonstration reactor - the CRER. DOE does not have this capability because the fuel rods from these facilities are too long to fit into the existing system. In addition, these rods are generally made of material which cannot be easily dissolved with the chemical processes presently used by DOE. 
The proposed modification would enable DOE to reprocess spent fuel from commercial reactors, the Fast Flux Test Facility, and the CRBR. A "front end" unit would be added to an existing reprocessing facility which would chop the spent fuel rods into lengths suitable for the existing system and leach the plutonium and other elements from the rods. DOE's preliminary estimates indicate that the "front-end" unit could be operational by fiscal year 1989 if the project is authorized by the Congress. These preliminary estimates also indicate that an existing reprocessing facility with the proposed modification could be capable of (1) storing about 200,000 to 500,000 kilograms of commercial or breeder reactor spent fuel, (2) reprocessing the spent fuel at a nominal rate of about 420,000 kilograms of heavy metal per year, and (3) producing 3,780 kilograms of plutonium per year. The estimated cost of building the "front-end" unit ranges from $\$ 300$ to $\$ 600$ million and annual operation and maintenance costs are estimated to be about $\$ 21$ million. DOE officials noted that the estimated figures are very preliminary, and cautioned that later cost estimates could differ significantly as more precise information is known. In addition, these rods are generally made of material which cannot be easily dissolved with the chemical processes presently used by DOE.

\subsubsection{Nucleonics Week, October 27, 1983, Special issue on the defeat of the CRBR in the Senate on October 26.}

The Senate voted 56-40 to kill the Clinch River Breeder Reactor. Two senators "paired" for-against and did not actually vote. Two senators did not vote.

It may be of interest that some of the Senators serving then are still serving.

- Against ( $n=56)$, still serving in government are Max Baucus $(D-M T)$, Joseph Biden $(D-D E)$, Jeff Bingaman (D-NM), Patrick Leahy (D-VT), Carl Levin (D-MI), Frank Lautenberg ( $D$-NJ), Daniel Inouye $(D-H I)$, Richard Lugar $(R-I N)$. Biden is Vice President. Bingaman and Lugar are retiring after this year.

- For $(n=40)$, still serving is Orrin Hatch (R-UT)

\subsubsection{DOE, "DRAFT Area Recommendation Report for the Crystalline Repository Project - Overview," report DOE/CH-15(0), January 1986.}

The author has found the overview of the Area Recommendation Report, which identified 12 candidate sites in 7 states for the second geologic repository. The next item in this Chapter discusses a DOE briefing presentation for the Area Recommendation Report.

Although this report is sometimes cited as the recommendations for the second repository, one of the paragraphs below makes the explicit statement that DOE was (at the time) also considering sites that had been characterized (but not selected) or evaluated (but not nominated) for the first repository. So, it appears incorrect to describe the second repository as necessarily being east of the Mississippi.

To implement its provisions, the NWPA established DOE's Office of Civilian Radioactive Waste Management (OCRWM). OCRWM is currently considering bedded salt deposits, salt domes, basalt, tuff, and crystalline rock as host rocks for geologic repositories. These rock types are being analyzed at different locations within the conterminous United States under four coordinated projects: the Basalt Waste Isolation Project, the Salt Repository Project, the Nevada Nuclear Waste Storage Investigations, and the Crystalline Repository Project.

For the first repository, the NWPA requires DOE to recommend to the President, from at least five nominated sites, three candidate sites to be characterized after which one site will be selected as the first repository. The rock types being considered as potential hosts for this first repository are basalt, salt, and tuff. 
While Congress has not yet authorized construction of a second geologic repository, the NWPA requires DOE to recommend a site for a second repository because of the stipulation that no more than 70,000 metric tons of radioactive waste and spent nuclear fuel be placed in the first repository until a second repository becomes operational. DOE is considering two sources of sites for the second repository: crystalline rock formations, which are already the subject of a comprehensive screening program conducted by the Crystalline Repository Project, and sites which will have been characterized for the first repository but are not selected for the first repository site, and sites evaluated but not nominated for site characterization for the first repository.

The 12 proposed potentially acceptable sites are located in the States of Georgia (1), Maine (2), Minnesota (3), New Hampshire (1), North Carolina (2), Virginia (2), and Wisconsin (1). Portions of the proposed potentially acceptable site in Wisconsin are located within the Menominee and Stockbridge-Munsee Indian Reservations and portions of one of the sites in Maine are located within the Penobscot and Passamaquoddy Indian Reservations.

Crystalline rocks were considered to be a viable host rock for a repository as early as 1957 . In mid--1979 DOE initiated a national survey to identify regions of crystalline rock with potential for isolating nuclear waste. Crystalline rocks are defined by the Crystalline Repository Project (CRP) as intrusive igneous (e.g., granite) and high-grade metamorphic rocks, rich in silicate minerals, with a grain size coarse enough that individual minerals can be distinguished with the unaided eye.

The national survey identified and recommended for further study three regions of crystalline rock (Figure 1). These regions, the North Central, Northeastern, and Southeastern Regions, span 17 States, each of which contains exposed or near-surface crystalline rock bodies. These states are Connecticut. Georgia, Maine, Maryland, Massachusetts, Michigan, Minnesota, New Hampshire, New Jersey, New York, North Carolina, Pennsylvania, Rhode Island. South Carolina, Vermont, Virginia, Wisconsin.

\subsubsection{David J. Rose, Learning about Energy, Plenum Press, New York, 1986.}

This book evolved out of Professor Roses' course notes on Energy Policy at MIT, a course the author took in 1981.

Clinch River Breeder Reactor Project was terminated in 1983.

The two indented paragraphs below are quotes from GAO in Rose's book.

Summary on [Page 309]

The GAO report at this point also deplores the termination of a smaller gas-cooled fast breeder reactor program.

"GAO recommends that [the Congress] require DOE to demonstration the viability of the LMFBR technology by mandating the construction of a breeder reactor facility. However, in making this recommendation, GAO wants to emphasize that it is not necessarily advocating the completion of the Clinch River project as the only means of moving the program forward."

"On the other hand, if the Congress cannot reach a resolution on whether to preserve the breeder option or if it does not wish to do so, GAO recommends that it consider terminating the breeder program.... GAO points out, however, that if the program is terminated it could cost many years of developmental time if the Congress later chooses to re-start it. If this should occur, the only alternative may be to purchase breeder reactors from some advanced, foreign nation."[Page 310] 
So the impasse continued until election day, 4 November 1980 . The new Reagan administration, committed generally to stimulating decisions via market forces, but also generally favorable to nuclear power (the U.S. federal nuclear R\&D program has never been determined by market forces) might take any of several paths vis-à-vis the LMFBR issue, and the time appeared ripe for a fresh, broad, and constructive debate, unencumbered by the necessity to defend past positions. But, as it turned out, the decision had already been made by election day to push strongly for government support of nuclear power, especially to build the Clinch River Breeder Reactor as its design then stood, all in the midst of simultaneous administration actions to dismantle DOE and remand many of its other activities to the custody of the marketplace. This was greeted joyously by most of the nuclear sector, but since then its longer-term difficulties have become more apparent, even to formerly uncritical supporters, and congressional support for the CRBR finally collapsed.[Page 310]

\subsubsection{DOE, "Briefing on the Draft Area Recommendation Report, Crystalline Repository Project," January-February, 1986.}

This briefing refers to the "Draft Area Recommendation Report" in which 12 sites in seven states are identified.

Crystalline Site Selection Process

- National Academy of Sciences and the Inter-Agency Review Group recommended crystalline rock as having potential for repository siting

- Site Screening

- National Survey-In 1983, DOE issued a national survey report on crystalline rocks which identified three regions for further study for possible repository sites.

- Regional Survey-Compiled regional geologic and environmental characterization reports (data base) for regions identified in the national survey. Developed methodology for screening from regions to specific areas for further study.

- Area Survey (field work)-Field investigations to determine if there are sites suitable for nomination/recommendation and site characterization.

- Nomination and recommendation

- Site characterization

- Request Congressional authority to construct

- Site recommendation and selection

- Licensing

- With Congressional authorization, construction

Figure 3 shows the regions considered for second repository. Figure 4 shows the specific sites. 


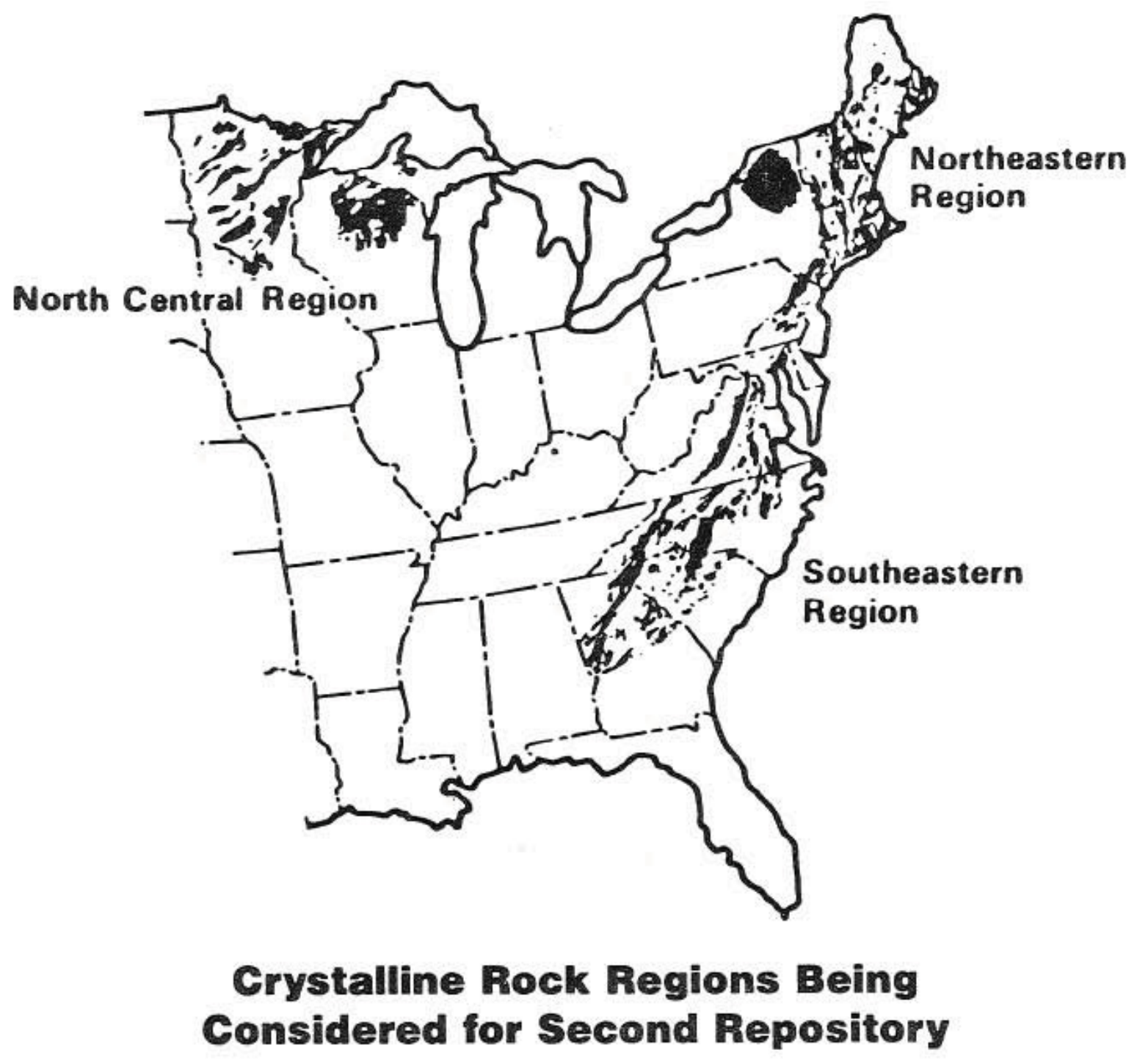

Figure 3. Crystalline Rock Regions Being Considered for Second Repository. 


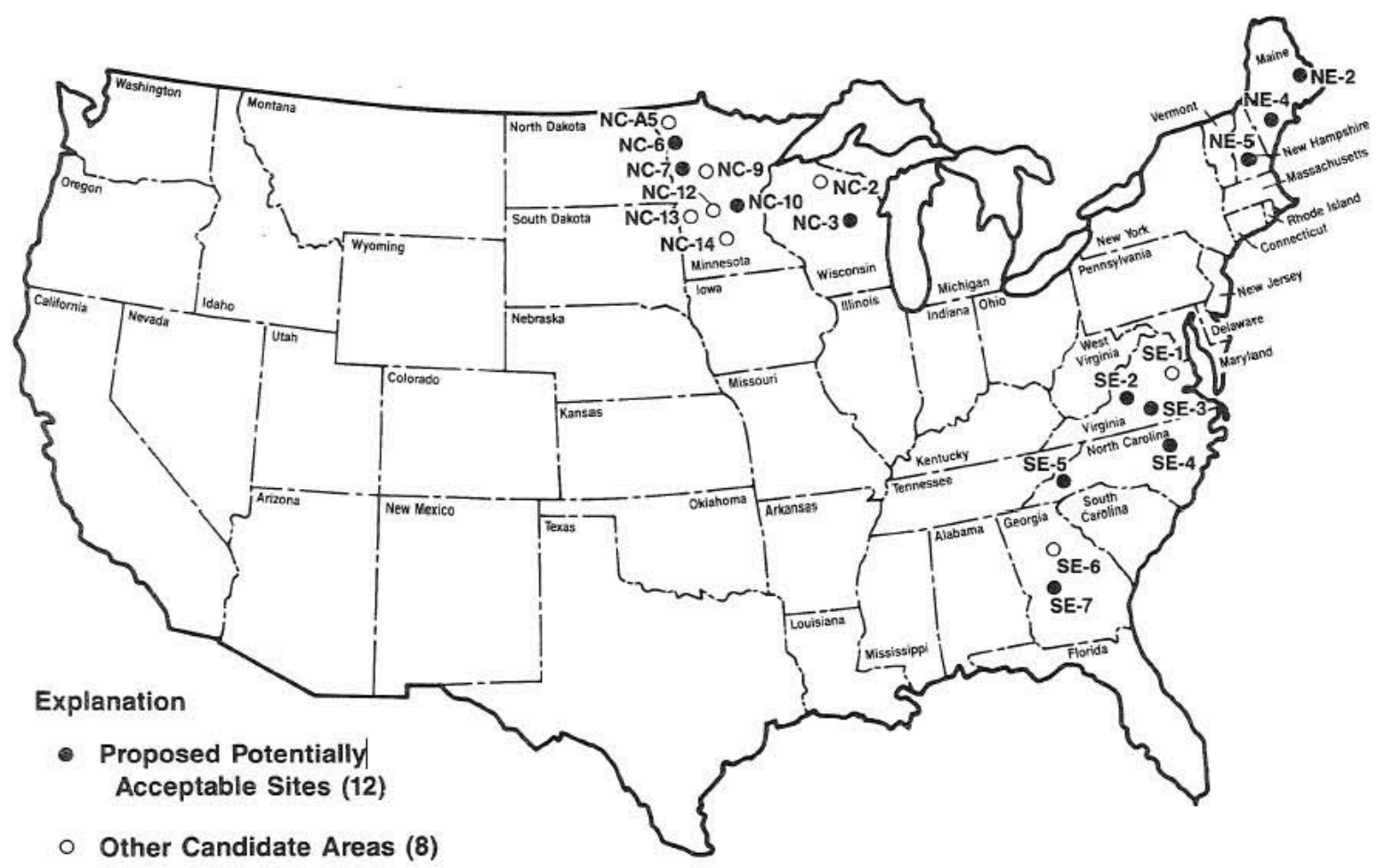

Proposed Potentially Acceptable Sites and Candidate Areas for the Second Repository

Figure 4. Proposed Potentially Acceptable Sites and Candidate Areas for the Second Repository.

The twelve potentially acceptable sites are in Minnesota, Wisconsin, Maine, New Hampshire, Virginia, North Carolina, and Georgia. There were eight additional candidate sites, all located in the same states.

DOE states that the second repository candidates must be crystalline rock sites, but does not state why, nor the definition of "crystalline rock". The definition of crystalline rock is in the overview of the draft Area Recommendation Report, which is the preceding item in this report.

What Sites are Eligible for Second Repository?

- Sites characterized but not selected for first repository

- Sites not nominated for first repository

- Crystalline rock sites

\subsubsection{DOE, "A Multiattribute Utility Analysis of Sites Nominated for Characterization for the First Radioactive-Waste Repository - A Decision- Aiding Methodology," DOE/RW-0074, May 1986.}

In February 1983, DOE identified nine potentially acceptable sites for the first repository in the following locations (the host rock of each site is shown in parentheses):

1. Vacherie dome, Louisiana (salt dome) 
2. Cypress Creek dome, Mississippi (salt dome)

3. Richton dome, Mississippi (salt dome)

4. Yucca Mountain, Nevada (tuff)

5. Deaf Smith County, Texas (bedded salt)

6. Swisher County, Texas (bedded salt)

7. Davis Canyon, Utah (bedded salt)

8. Lavender Canyon, Utah (bedded salt)

9. Reference repository location, Hanford Site, Washington (basalt flows)

To document the process specified above, draft environmental assessments (EAs) were prepared for each of the nine sites identified as potentially acceptable (DOE, 1984c-g). The draft EAs, which also include the evaluations and descriptions specified by the Act, were issued for public comment in December 1984.

This meant they included draft indications of which were to proceed to "nomination".

In December 1984, the Department of Energy (DOE) published draft environmental assessments EA's to support the proposed nomination of five sites and the recommendation of three sites for characterization for the first radioactivewaste repository.

\subsubsection{GAO, "Nuclear Waste - Issues Concerning DOE's Postponement of Second Repository Siting Activities," report RCED-86-200FS, July 30, 1986.}

This document confirms the existence of a January 1986 DOE report that identified candidate second geologic repository sites in seven states. Because it is capitalized, it appears that the report title included the phrase "Area Recommendation Report."

DOE announced on May 28, 1986, that it was postponing site-specific work for a second nuclear waste repository because of progress made in siting the first repository and the uncertainty about when a second repository might be needed. DOE emphasized at the time that the second repository program was not terminated and that non-site-specific technical studies would continue. At the time of the postponement decision, DOE's Office of Civilian Radioactive Waste Management (OCRWM) was in the process of preparing an Area Recommendation Report that would have formally identified potential sites for a second nuclear waste repository. A draft of that report, released in January 1986, tentatively identified potential sites in seven different states. The draft report received considerable comment and objections by concerned states, Indian tribes, and individual citizens. Following the postponement decision, actions were promptly

The Director told us in June 1986 that since December, a number of changing factors contributed to the consideration and selection of the option to postpone second repository site-specific efforts.

These included:

(1) A decline in the estimated quantities of spent fuel to be generated by nuclear power plants.

(2) An increased confidence in the technical suitability of the candidate first repository sites. 
(3) Questions about to the need to spend an estimated $\$ 600$ million to $\$ 800$ million to determine candidate second repository sites before determining when and if such a repository is needed.

(4) OCRWM's growing expectation that a monitored retrievable storage (MRS) system will be authorized by the Congress.

The Director also emphasized that DOE's current Mission Plan, which represents DOE's overall strategy for the civilian radioactive waste program, calls for the first repository to begin accepting about 3,000 metric tons of uranium waste (hereafter referred to as metric tons) per year beginning around the year 2000 . Thus by 2020 , about 60,000 metric tons would be in the repository - still short of the legislated cap of 70,000 metric tons. 2 This time frame, he said, allows for the postponement of expensive second repository siting activities until the 1990's when the need can be better defined.

The Director also told us that the number (over 60,000) and critical nature of the comments received on the draft Area Recommendation Report had an impact on the decision--but that the main reasons for the postponement were those cited above.

\subsubsection{GAO, "Nuclear Nonproliferation - Department of Energy Needs Tighter Controls over Reprocessing Information," report RCED-87-150, August 1987.}

This report makes it clear that DOE has the legal authority (e.g. under the Atomic Energy Act of
1954,[AEA1954] as amended) to control information.

Since 1974, when India exploded a nuclear device using plutonium obtained by reprocessing civilian nuclear fuel, the United States has tried to strengthen controls over exports of nuclear technology and hardware in an effort to curb the spread of nuclear weapons. Today, reports of Israel's nuclear arsenal and Pakistan's development of nuclear weapons capability have heightened proliferation concerns.

Because the Department of Energy (DOE) is responsible for controlling the dissemination of reprocessing information, Senator William Proxmire asked GAO to examine DOE'S controls over (1) the dissemination of reprocessing information, (2) the transfer of reprocessing technology to foreign countries, and (3) foreign nationals' involvement in sensitive nuclear programs.

The Atomic Energy Act of 1954 places controls over the transfer to foreign countries of unclassified nuclear information that could be helpful to weapons production. The Nuclear Non-Proliferation Act of 1978 established additional controls. The 1978 act allows the transfer of sensitive nuclear technologywhich includes, among other things, information that is unclassified, not publicly available, and important to the design of a reprocessing facility-only if the recipient country agrees to U.S. approval rights.

Through reprocessing, plutonium can be obtained from used nuclear fuel to produce a nuclear weapon. Since both plutonium and reprocessing also have commercial applications, the government declassified reprocessing technology and information in 1959.

DOE is the focal point for reprocessing activities in this country. It operates defense-related reprocessing facilities and conducts research in its own laboratories, at universities, and with foreign countries related to reprocessing applications. Currently, no commercial reprocessing plants exist or are planned in this country.

DOE needs better controls over the dissemination of reprocessing documents because countries that pose a proliferation or security risk routinely obtain reprocessing information published by DOE. DOE tries to withhold some information that has trade value (applied technology) and could use this approach on a broader scale. However, the possibility exists that applied technology information could be obtained 
under the Freedom of Information Act, and DOE needs to seek an exemption from that act to protect such information.

DOE has transferred to other countries information appearing to meet the definition of sensitive nuclear technology. Since DOE does not believe this information is sensitive nuclear technology, it has not obtained the required approval rights over the plutonium produced.

DOE places no restrictions on foreign nationals' involvement in DOE funded reprocessing research at colleges and universities. Although DOE now funds only five such projects, the possibility exists that DOE could contribute to foreign expertise in this area.

Internationally, however, the proliferation concerns of reprocessing have been realized. India exploded a nuclear device in 1974 that contained plutonium obtained from reprocessed research reactor fuel, and Israel's widely reported nuclear arsenal is believed to use plutonium from a secret reprocessing facility.

However, India's 1974 explosion of a nuclear device caused the United States to reassess its nonproliferation controls because the plutonium used in the explosion was produced, albeit indirectly, with U.S. assistance. In order to reduce the risk of further proliferation, the Congress enacted the Nuclear Non-Proliferation Act of 1978 (NNPA) and provided stronger controls over the export of U.S. nuclear technology. In passing the act, the Congress found that the proliferation of nuclear weapons posed a grave threat to the security of the nation and an urgent and imperative need existed to prevent further proliferation. The Congress wanted effective and efficient controls established on the use of nuclear material and technology exported for peaceful purposes that would provide greater assurance against the diversion of materials and technology essential to the creation of, or the ability to create, nuclear weapons.

The NNPA substantially amended the Atomic Energy Act, revised the terms and conditions for U.S. nuclear cooperation with other countries, and committed the United States to a broad range of unilateral and international initiatives to curb proliferation risks. Among other things, the NNPA required stronger domestic controls over nuclear-related exports.

Under the provisions of the Atomic Energy Act as amended by the NNPA, any reprocessing assistance provided to foreign countries must be approved by various federal organizations, depending on the type of assistance - hardware or technology. The Nuclear Regulatory Commission and the Department of Commerce license the exports of nuclear facilities, components, and other hardware. The Commission must license any exports of nuclear reprocessing facilities or specially designed components for such facilities. Components that have a dual use (applications to both nuclear and nonnuclear facilities) must receive a Commerce export license. Such dual-use components are also reviewed by DOE before Commerce issues a license.

Some assistance provided to foreign nuclear programs is not hardware but consists of the technology and know-how to build and operate nuclear facilities. Such assistance must be authorized by the Secretary of Energy. As stated in section 57(b) of the act:

"It shall be unlawful for any person to directly or indirectly engage in the production of any special nuclear material outside the United States except (1) as specifically authorized under an agreement for cooperation ... or (2) upon authorization by the Secretary of Energy after a determination that such activity will not be inimical to the interests of the United States ...."

The act further provides that the Secretary can authorize an export only with the concurrence of the Department of State and after consultation with the Departments of Defense and Commerce, the Arms Control and Disarmament Agency, and the Nuclear Regulatory Commission. Activities requiring the Secretary's authorization include facility designs and equipment manufacturing technology, engineering 
services, and the training of foreign nationals in nuclear technology (other than through courses given by universities).

In addition to the requirements of section 57(b), the NNPA added sections 127 and 128 to the Atomic Energy Act. These sections require that any exports that involve, among other things, the transfer of sensitive nuclear technology (SNT)-which the act defines as information that is not Restricted Data, is not publicly available, and is important to the design, construction, operation, or maintenance of a reprocessing, enrichment, or heavy water production facility - must meet more stringent export conditions. These conditions require that DOE obtain additional assurances from the recipient country regarding the nuclear equipment or materials produced through, or by the use of, the exported technology.

\subsubsection{Allied-General Nuclear Services, et al., Petitioners v. United States of America; brief for the United States in Opposition, 1988.}

Barnwell got caught up with the establishment of NEPA. Carter's policy statement influenced the NRC to terminate Barnwell hearings but when the case reached the Supreme Court, the U.S. Government argued below that the AEC's actions were authorized by The Atomic Energy Act's granting of authority to the $A E C / N R C$, not any legal force of Carter's statement.

No. 87-1902

\section{In The Supreme Court Of The United States}

\section{October Term, 1988}

\section{On Petition For A Writ Of Certiorari To The United States Court Of Appeals For The Federal Circuit}

\section{Brief For The United States In Opposition}

In light of President Carter's statement, the Commission announced its intent to reassess "the future course and scope of GESMO, the review of recycle-related license applications, and the matter of interim licensing." 42 Fed. Reg. 22964 (1977). The Chairman of the Commission sought the President's views on those matters. A White House official responded that "the President believes that his non-proliferation initiatives would be assisted both domestically and internationally if the Commission were to terminate the GESMO proceedings ..." (id. at 57186). On December 23, 1977, after receiving comments from interested parties, the Commission issued an order terminating the GESMO proceedings and most license proceedings relating to plutonium recycling. See id. at 65334. The Commission, however, stated that it would reexamine this decision after two studies of alternative fuel cycles were completed (ibid; Westinghouse Elec. Corp. v. NRC, 598 F.2d at 765).

Petitioners and others sought judicial review of the Commission's order. The United States Court of Appeals for the Third Circuit upheld the Commission's action. The Third Circuit stated that, "(g)iven th(e) broad delegation of authority to the NRC to choose the necessary means by which to implement the general policy objectives of the AEA, we cannot say that the NRC must inexorably proceed with the processing of license applications and the development of a final GESMO when in its judgment to do so would endanger the attainment of its statutory objectives." Westinghouse Elec. Corp. v. NRC, 598 F.2d 761,771 .

In early 1980, when the two studies regarding fuel cycles were complete, the Chairman of the Commission asked the President whether the Administration's views had changed. The White House responded that President Carter believed "that the GESMO proceedings should remain terminated and that a reopening of GESMO would be inimical to national security ...." The Commission published this 
response and sought public comments on whether the Commission should reopen its GESMO and license proceedings. See 45 Fed. Reg. 53933 (1980).

Neither petitioners nor any other applicant for a license to construct or operate a reprocessing facility responded.

In early 1981, President Reagan announced that he was "lifting the indefinite ban which previous administrations placed on commercial reprocessing activities in the United States." Statement Announcing a Series of Policy Initiatives on Nuclear Energy, Pub. Papers 903 (Oct 8, 1981). President Reagan stated that it is "important that the private sector take the lead in developing commercial reprocessing services" (ibid.). Petitioners, however, have not sought to reopen either the GESMO proceedings or the proceeding concerning its application for a license to operate the Barnwell plant. Petitioners instead filed this suit alleging that the Commission's actions constitute a taking of the Barnwell reprocessing plant for public use without just compensation (C.A. App. 48, 51, 54, 55).

\subsubsection{DOE, "Analysis of the Total System Life Cycle Cost for the Civilian Radioactive Waste Management Program," report DOE/RW-0236, May 1989.}

The total-system life-cycle cost (TSLCC) analysis for the Department of Energy's (DOE) Civilian Radioactive Waste Management Program is an ongoing activity that helps determine whether the revenue-producing mechanism established by the Nuclear Waste Policy Act of 1982--a fee levied on electricity generated in commercial nuclear power plants--is sufficient to cover the cost of the program. This report provides cost estimates for the sixth annual evaluation of the adequacy of the fee and is consistent with the program strategy and plans contained in the DOE'S Draft 1988 Mission Plan Amendment. The total-system cost for the system with a repository at Yucca Mountain, Nevada, a facility for monitored retrievable storage (MRS), and a transportation system is estimated at $\$ 24$ billion (expressed in constant 1988 dollars). In the event that a second repository is required and is authorized by the Congress, the total-system cost is estimated at $\$ 31$ to $\$ 33$ billion, depending on the quantity of spent fuel to be disposed of.

The \$7-billion cost savings for the single-repository system in comparison with the two-repository system is due to the elimination of $\$ 3$ billion for second-repository development and $\$ 7$ billion for the secondrepository facility. These savings are offset by $\$ 2$ billion in additional costs at the first repository and $\$ 1$ billion in combined higher costs for the MRS facility and transportation.

The revised TSLCC estimates have changed from the June 1987 analysis because of two major types of changes: (1) cost impacts due to changes in design assumptions and cost data and (2) the passage of the Nuclear Waste Policy Amendments Act of 1987 (the Amendments Act). For a two-repository system, the changes in design assumptions and cost data result in a $\$ 6$ billion increase in total-system costs. However, the provisions of the Amendments Act cause a cost reduction of $\$ 6$ billion in total-system costs.

Therefore, for a two -repository system, this TSLCC estimate is only slightly lower than that for the comparable reference case from the previous TSLCC analysis.

To estimate the share of the total-system costs that should be allocated to the disposal of defense highlevel waste in the civilian repositories, the methodology announced by the DOE in the Federal Register in August 1987 was used. Estimates of the defense-waste share of the costs are about $\$ 4$ billion (15 percent of the total) for the single-repository system and about $\$ 6$ billion (19 percent of the total) for the tworepository system. 


\subsubsection{DOE, "Preliminary Estimates of the Total-System Cost for the Restructured Program: An Addendum to the May 1989 Analysis of the Total-system Life Cycle Cost for the Civilian Radioactive Waste Management Program," report DOE/RW-0295SP, December 1990.}

The total-system life-cycle cost (TSLCC) analysis for the Department of Energy's (DOE) Civilian Radioactive Waste Management Program is an ongoing activity that helps determine whether the revenue-producing mechanism established by the Nuclear Waste Policy Act of 1982--a fee levied on electricity generated and sold by commercial nuclear power plants--is sufficient to cover the cost of the program. This report provides cost estimates for the sixth annual evaluation of the adequacy of the fee. The costs contained in this report represent a preliminary analysis of the cost impacts associated with the Secretary of Energy's ReDort to Congress on Reassessment of the Civilian Radioactive Waste Management Program issued in November 1989. The major elements of the restructured program announced in this report which pertain to the program's life-cycle costs are: a prioritization of the scientific investigations program at the Yucca Mountain candidate site to focus on identification of potentially adverse conditions, a delay in the start of repository operations until 2010, the start of limited waste acceptance at the monitored retrievable storage (MRS) facility in 1998, and the start of waste acceptance at the full-capability MRS facility in 2000. The cost estimates presented in this TSLCC report are updates to the estimates contained in the May 1989 TSLCC report and do not represent a comprehensive reevaluation of all aspects of the total-system cost analysis; thus, this report is issued as an addendum to the previous TSLCC report. All costs are expressed in 1988 dollars in order to be consistent with the May 1989 TSLCC report.

Based on the restructured program, the: total-system cost for the system with a repository at the candidate site at Yucca Mountain in Nevada, a facility for monitored retrievable storage (MRS), and a transportation system is estimated at $\$ 26$ billion (expressed in constant 1988 dollars). In the event that a second repository is required and is authorized by the Congress, the total-system cost is estimated at $\$ 34$ to $\$ 35$ billion, depending on the quantity of spent fuel and high-level waste (HLW) requiring disposal.

The restructured program results in an increase of approximately $\$ 2$ billion in total-system costs from the estimates contained in the May 1989 TSLCC report. The vast majority of this cost impact is due to an increase in the development and evaluation (D\&E) costs resulting from additional costs projected to be incurred during the 7-year delay in the repository program. The MRS facility and transportation costs have also increased slightly due primarily to the additional costs associated with the transport/storage system used to provide waste acceptance at the MRS facility in 1998 and 1999.

\subsubsection{G. H. W. Bush, "President's Statement," Office of the Press Secretary, July 13, 1992.}

A very similar version of the paragraph below also appears in a then-classified document dated July 10 (declassified February 15, 1999).

Yet we need to do more. The demand for these weapons persists, and new suppliers of key technologies are emerging. Export controls alone cannot create an airtight seal against proliferation. In an era of advancing technology and trade liberalization, we need to employ the full range of political, security, intelligence, and other tools at our disposal. Therefore, I have set forth today a set of principles to guide our non-proliferation efforts in the years ahead and directed a number of steps to supplement our existing efforts. These steps include a decision not to produce plutonium and highly enriched uranium for nuclear explosive purposes and a number of proposals to strengthen international actions against those who contribute to the spread of weapons of mass destruction and the missiles that deliver them. 


\title{
4.1.44 White House, Office of the Press Secretary, "Non-proliferation Initiative," Fact sheet, July 13, 1992.
}

Nuclear Materials Production. The United States shall not produce plutonium or highly enriched uranium for nuclear explosive purposes. This step is intended to encourage countries in regions of tension, such as the Middle East and South Asia, to take similar actions, such as those proposed in the May 1991 Middle East arms control initiative. The United States will seek further multilateral support for concrete measures to discourage production or acquisition of weapons-usable nuclear materials in South Asia, the Korean Peninsula, or other areas where they would increase the risk of proliferation.

\subsubsection{W. J. Clinton, "Non-Proliferation and Export Control Policy," Presidential Decision Directive-13 (PDD-13), September 1993.}

This document is still classified, the next item in this report is the press release on the Clinton's policy.

The message I received from the Clinton Presidential library is as follows; my request to them is below that.

\author{
"Clinton Library" <Clinton.Library@nara.gov>, 10/18/2011 09:25 AM \\ Dear Dr. Piet,
}

Thank you for contacting the Clinton Presidential Library. Presidential Decision Directive-13 (PDD-13) regarding "Non-Proliferation and Export Control Policy" has yet to be declassified. We would suggest that it might be easier for you to go through your chain of command at the Department of Energy to gain access to this PDD. Policy documents such as PDD-13 get distributed by the Executive Secretary of a department or agency. The Department of Energy should have a copy of this and their copy is considered a federal record. Anything obtained through us is considered a presidential record and follows the guidelines of the Presidential Records Act (PRA) of 1978. More on the PRA can be found at the following websites: http://www.archives.gov/presidential-libraries/laws/1978-act.html and http://www.archives.gov/about/laws/presidential-records.html. Since this document has neither been declassified nor released, the only way of gaining access to it through us is through a special access request on behalf of the incumbent President, clearances would then need to be granted, and the National Security Council (NSC) as the equity holding agency would need to authorize your access by establishing a need to know. The PRA, thus, makes it a lengthier process for gaining access than if you can find a federal record copy within the Department of Energy.

This PDD, however, has been requested under a Mandatory Declassification Review (MDR) and if you would like you could request to "piggy-back" on that request. There is, however, no time frame as to when this PDD will come back from MDR so it may be awhile before the document could be declassified and released. More on the MDR process can be found at this web address: http://www.archives.gov/isoo/oversight-groups/iscap/mdr-appeals.html. I hope that this information helps, and if you have any further questions please do not hesitate to contact us again. 
Sincerely,

Jason Kaplan

Archives Technician

Clinton Presidential Library

1200 President Clinton Avenue

Little Rock, Arkansas 72201

(501) 244-2877

>> Steven J Piet <Steven.Piet@inl.gov> 10/10/2011 2:49 PM $\gg>$

I would like to obtain

"Non-Proliferation and Export Control Policy," Presidential Decision Directive-13 (PDD-13), September 1993.

If this is not declassified, I would like an authorative description of its summary.

Sincerely,

Dr. Steven J. Piet

Idaho National Laboratory

steven.piet@inl.gov

208-526-5252

\subsubsection{6 "Fact Sheet - Nonproliferation and Export Control Policy," The White House, Office of the Press Secretary, September 27, 1993.}

The United States does not encourage the civil use of plutonium and, accordingly, does not itself engage in plutonium reprocessing for either nuclear power or nuclear explosive purposes. The United States, however, will maintain its existing commitments regarding the use of plutonium in civil nuclear programs in Western Europe and Japan.

The U.S. will undertake a comprehensive approach to the growing accumulation of fissile material from dismantled nuclear weapons and within civil nuclear programs. Under this approach, the U.S. will:

- See to eliminate where possible the accumulation of stockpiles of highly-enriched uranium or plutonium and to ensure that where these materials already exist they are subject to the highest standards of safety, security, and international accountability.

- Propose a multilateral convention prohibiting the production of highly-enriched uranium or plutonium for nuclear explosives purposes or outside of international safeguards.

- Encourage more restrictive regional arrangements to constrain fissile material production in regions of instability and high proliferation risk.

- Submit U.S. fissile material no longer needed for our deterrent to inspection by the International Atomic Energy Agency.

- Pursue the purchase of highly-enriched uranium from the former Soviet Union and other countries and its conversion to peaceful use as reactor fuel. 
- Explore means to limit the stockpiling of plutonium from civil nuclear programs, and seek to minimize the civil use of highly-enriched uranium."

- Initiate a comprehensive review of long-term options for plutonium disposition, taking into account technical, nonproliferation, environmental, budgetary and economic considerations. Russia and other nations with relevant interest and experience will be invited to participate in this study.

\subsubsection{OTA, "Dismantling the Bomb and Managing the Nuclear Materials," report OTA-O-572, September 1993.}

\section{Appendix Volume II, Part One}

\section{Appendix I. Incentives/Disincentives}

This appendix has a solid evaluation of what had happened up to 1993 in various weapon states and almost weapon states - Iran, Israel, Brazil, South Africa, South Korea, Germany, Japan, and Sweden.

\section{Appendix III. Non-State Adversaries}

Chapter II. Causes of Increased Concern about the Potential Nuclear Non-State Adversary (entire chapter extracted here because of its relatively deep understanding of what drives concerns about nuclear power; the yellow highlights are mine)

If there is an unwritten law of human behavior that no serious preventive measures will be taken until after the first catastrophe occurs, that law does not apply in the area of nuclear safeguards. Concern about the potential non-State adversary grew in the late 1960 s although no criminal or politically-motivated terrorist had ever carried out any action against nuclear programs or involving nuclear material. Concern has continued to grow, although, apart from a handful of minor incidents, no serious action has occurred. Judging by the number of hearings, studies, reports, and articles on the topic, and by the increased security measures, the possibility that terrorists or criminals might carry out some action is being taken seriously. This is not to say that security measures are adequate. Nor is it to say that all those in government agencies and the private components of the nuclear industry equally accept the notion that there is a real threat, or that they have enthusiastically supported measures to improve security. They have been embarrassed by some obvious deficiencies that have been revealed, and in some cases they have been forced to adopt new security measures. Many, however, still view their problem as one of compliance, not one of security against a threat they are not convinced exists. Asked what he regarded as the biggest threat to his nuclear facility, one director of security replied, "A dedicated and determined band of NRC inspectors."

The fear that some subnational group or private individual might "go nuclear" is not a new one, as Roberta Wohlstetter pointed out in her recent article in Survival. "In a memorandum to President Truman of 25 April 1945, Henry Stimson predicted that 'the future may see a time when such a weapon may be constructed in secret and used suddenly and effectively with devastating power by a willful nation or group against an unsuspecting nation or group of much greater size and material power."

The current concern seems to result from a confluence of several developments in the late 1960's and early 1970's. Foremost among these is the rapid growth, actual and projected, of nuclear power plants and the attendant fuel-making, reprocessing and nuclear waste disposal facilities. Increased demands for energy, the impact of the Arab oil embargo in 1973, the rapid rise in oil prices, all have given impetus to developing nuclear power as an alternative source of energy. In the United States, at the end of 1974, it was anticipated that there would be over 1000 nuclear reactors in the country by the end of the century. 
The 1975 OECD and IAEA projections anticipated over 2000 nuclear reactors worldwide by the year 2000. (See Volume 1, Chapter X, page 244).

Reactors produce plutonium as a by-product. With the increase in the number of reactors will come an increase in the worldwide production of plutonium, the stuff atomic bombs are made of. In 1975, the annual worldwide production of plutonium was 20,000 kilograms. By 1983 , it has been estimated that annual production will reach 70,000 kilograms (plus or minus 15-20 percent to provide for uncertainties). By the year 2000 , annual plutonium production may reach 400,000 kilograms, a quantity roughly sufficient for 40,000 bombs. The proliferation of nuclear facilities with the increasing availability of and traffic in plutonium will, it is feared, provide numerous opportunities for sabotage and theft.

Although diversion of plutonium by a government for military purposes may be more likely than diversion or theft by a non-State, it is the latter which may be perceived as the more worrisome problem by the general public. That Argentina or Pakistan may eventually acquire a nuclear weapon does not seem to cause great alarm (except perhaps to citizens of neighboring countries). People have come to accept the presence of nuclear weapons and have grown accustomed to living with the possibility of nuclear war. One nation more or less with nuclear weapons does not seem to make a lot of difference. In contrast, the possibility that some band of criminals or terrorists may acquire a nuclear capability causes a great deal of anxiety. This is no matter of remote debate by military deterrence strategists. Crime and terrorism affect people very personally at a daily-life level. They come to us nightly in the form of human dramas on our television screens in which the audience participates as vicarious victims.

Concurrent with the expansion of nuclear power, the environmentalist movement gained strength and was something new. The word "environmentalist" does not even appear in dictionaries that are ten years old. "Environmentalists," although they were not called that, have always existed in America primarily as a local phenomenon to preserve a specific piece of landscape. A national environmental movement is a relatively recent development and represents a new and powerful voice in modern society.

Environmentalists have challenged some of the basic tenets of modern society: continuous economic growth, industrial expansion, the concept of progress itself which had somehow come to be synonymous with technological advance. Although at first nuclear power seemed to be a solution to environmentalists concerns about the pollution resulting from the use of fossil fuels, many began to question the effects of nuclear power on the environment. They worried about thermal pollution, the amount of radiation emitted during normal operations or that might accidently be released, the disposal of radioactive wastes. The initial focus on the adverse side effects of nuclear energy shifted to concern about accidents. How safe were nuclear reactors? What would happen if the system designed to meet emergencies failed? Later, they gave increasing attention to the possibilities and consequences of deliberate malevolent actions by terrorists or criminals. Man's malevolence became a major philosophical premise of the foes of nuclear energy, or, as David Comey put it, "No longer is one calculating the chances of malfunctioning machines; one is guessing the probability of malfunctioning human beings. One does not have to be a psychiatrist to realize that probability is high: one need only read the newspaper." Nuclear power is bad because man is bad.

This struck a responsive chord in the public mind. There is undeniably a degree of anxiety in the mind of the public concerning nuclear power. Nuclear power is guilty of original sin. The nuclear age began with a bomb not a power plant, and the word "nuclear" recalls Hiroshima not Indian Point. Nuclear power is the most potent, and to many the most sinister, force known to man. However, nuclear power plants (light water reactors) are not nuclear bombs. Successful sabotage could theoretically result in a release of radioactive material, but a reactor cannot be turned into a nuclear bomb. Only recently has some of the public come to understand this point. If people are already uneasy about nuclear power and worried about terrorists, it is not difficult to frighten them with a forecast of some kind of nuclear action by terrorists. The mere proximity of the words "terrorist" and "nuclear" induce fear. 
If there was any doubt about man's maliciousness, it could be dispelled by reading the newspapers or turning on the television - news or drama. There is no convincing evidence that violence on television or in the movies causes people to be violent, but it may affect one's view of the world. Those who are regularly exposed to violence on the screen tend to see the real world as a more violent place.

It is, however, not simply the portrayal of violence that altered perceptions in the $1960 \mathrm{~s}$. Crime, particularly violent crime, often random, needlessly violent crime, increased by epidemic proportions. Political violence in the form of international terrorism also increased in the late 1960 s and by the early 1970s had become a serious worldwide problem. Assassins, kidnappers, and bombers were no longer remote figures associated with the Russian Revolution and wartime serials. They regularly kidnapped government officials and businessmen, hijacked airliners, gunned down passengers in airline terminals, murdered Olympic athletes, set bombs off in restaurants and railroad stations. Their violence was no longer confined to guerrilla struggles in remote colonies or insurgences in Third World countries. Terrorists crossed national borders to carry out their attacks on virtually every continent. No country was neutral, no citizen safe.

Events of the past fifteen years also have made it difficult not to have lost some confidence in our social, political, and economic institutions. Social mores were challenged. Basic lifestyles were changing. Within 13 years, five men have held the office of president: one was assassinated, one virtually abdicated, one resigned in disgrace, and one was not elected. In addition to one successful assassination of a president, there were two more attempts against a president's life, and two presidential candidates were shot, one fatally. American military involvement in the war in Indochina led ultimately to disaster. At home, news from Indochina triggered and provided the rationale for violent protests, bombings, and ultimately the appearance of genuine domestic terrorist groups. For the first time, it seemed (though not in reality for the first time) that there was political violence in the United States. Looking back, the passage to America's third century was a very rough ride.

This turbulence was not a uniquely American phenomenon. Japan and the nations of Western Europe suffered from bad cases of political scandal and upheaval, and also from domestic political violence unprecedented since the thirties. Corporations too were shown to have lied, misled, bribed, and yielded to blackmail.

Such revelations do not inspire confidence in claims by government or industry that nuclear safeguards are adequate now, or that the increased measures of security considered necessary to protect nuclear programs would not be abused or that governments indeed would be able to prevent diversion or theft or protect their citizens against nuclear terrorists. There was and is reason for doubt and fear. Doubt and fear are selling well anyway. There seems to be a popular market for doom, whether the "light doom" of, for instance, the Club of Rome, or the "heavy doom" of those who warn people to have a year's supply of food and a shotgun at home, or the religious groups who firmly believe that Armageddon is just around the corner.

\subsubsection{GAO, "Nuclear Science - Developing Technology to Reduce Radioactive Waste May Take Decades and Be Costly," report RCED-94-16s, December 1993.}

This report compares five concepts. The author of the current report has assembled the following table, but the evaluations are from the original report. In particular, the report has a subsection "Estimated Time Required to Transmute Existing Spent Fuel" for each of the concepts. And, it identifies the approach to be used, not just for Pu, but for minor actinides but Tc99 and I-129. This is one of the first mentions of minor actinides found. 
Table 7 of report. Author's Summary Table of Report RCED-94-16s.

\begin{tabular}{|c|c|c|c|c|}
\hline $\begin{array}{l}\text { Institutions } \\
\text { mentioned }\end{array}$ & Reactor & Separations & $\begin{array}{l}\text { "Time to transmute } \\
\text { existing spent fuel" }\end{array}$ & MA, Tc-99, I-129 \\
\hline $\begin{array}{l}\text { ANL and } \\
\text { GE }\end{array}$ & $\begin{array}{l}\text { Advanced liquid- } \\
\text { metal reactor } \\
\text { (ALMR)/Integral } \\
\text { Fast Reactor } \\
\text { (IFR) }\end{array}$ & $\begin{array}{l}\text { Pyroprocessing of } \\
\text { metal fuel "a } \\
\text { process similar to } \\
\text { the one used on the } \\
\text { production of the } \\
\text { metal aluminum } \\
\text { from its ore." } \\
\text { Separation of } L W R \\
\text { fuel not addressed. }\end{array}$ & $\begin{array}{l}C R=0.65 \\
\text { " } 1 \text { metric ton of } \\
\text { actinides by } 2240 . "\end{array}$ & $\begin{array}{l}\text { MA recycled in fuel. } \\
\text { "provides convenient } \\
\text { chemistry to incorporate } \\
\text { some other long-lived } \\
\text { radioactive materials - } \\
\text { mainly I-129 and Tc-99, } \\
\text { which are not transmuted } \\
\text { - into chemical forms } \\
\text { that will be immobile } \\
\text { when placed in a } \\
\text { geologic repository." }\end{array}$ \\
\hline LANL & $\begin{array}{l}\text { Accelerator } \\
\text { Transmutation of } \\
\text { Waste (ATW) - } \\
\text { aqueous version } \\
\text { in which targets } \\
\text { see thermal } \\
\text { neutrons }\end{array}$ & $\begin{array}{l}\text { Separation of ATW- } \\
\text { irradiated material } \\
\text { not needed. } \\
\text { Separation of LWR } \\
\text { fuel not addressed. }\end{array}$ & 2055 & $\begin{array}{l}\text { "This intense thermal } \\
\text { neutron flux is a basis } \\
\text { for the unique features of } \\
\text { ATW. Furthermore, the } \\
\text { thermal neutrons can } \\
\text { transmute I-129 and Tc- } \\
99 \text {, which the ALMR } \\
\text { cannot do efficiently." }\end{array}$ \\
\hline $\mathrm{BNL}$ & $\begin{array}{l}\text { LINAC based } \\
\text { variant of LANL } \\
\text { concept }\end{array}$ & \multirow{3}{*}{$\begin{array}{l}\text { Separation of LWR } \\
\text { fuel via PUREX, } \\
\text { followed by TRUEX } \\
\text { to get } P u, U, T R U \text {, } \\
\text { and } F P \text {. }\end{array}$} & $\begin{array}{l}2035-2050, \text { but " } 817 \\
\text { metric tons of } \\
\text { plutonium would } \\
\text { still remain." }\end{array}$ & $\begin{array}{l}\text { "Phoenix does not } \\
\text { transmute plutonium, } \\
\text { uranium, or technetium." }\end{array}$ \\
\hline $\mathrm{BNL}$ & $\begin{array}{l}\text { Particle-Bed } \\
\text { Reactor (PBR), } \\
\text { i.e., a pebble bed } \\
\text { HTGR. }\end{array}$ & & $\begin{array}{l}\text { Minor actinides by } \\
2050 . \text { Plutonium by } \\
2160 .\end{array}$ & $\begin{array}{l}\text { "Destroy actinides and } \\
\text { long-live fission } \\
\text { products from LWRs } \\
\text { and defense wastes." }\end{array}$ \\
\hline Hanford & $\begin{array}{l}\text { Cleanup Fast } \\
\text { Reactor (CLFR), } \\
\text { an oxide-fueled } \\
\text { fast reactor }\end{array}$ & & \multicolumn{2}{|c|}{$\begin{array}{l}\text { With deployment in } 2015 \text {, "begins the } \\
\text { elimination of LWR spent fuel in } 2030 \text { and } \\
\text { requires somewhat less than } 100 \text { years to reduce } \\
\text { the inventories of Tc } 99 \text { and } I-129 \text { by a factor of } \\
100 \text {. The report did not develop reduction } \\
\text { estimates for the transuranic elements." }\end{array}$} \\
\hline
\end{tabular}

\subsubsection{NAS1994, Committee on International Security and Arms Control, "Management and Disposition of Excess Weapons Plutonium," National Academy Press, Washington DC, 1994.}

President Obama's Science Advisor, John Holdren, chaired this activity. One of the major arguments for the MOX approach is the dilution of $P u$ with uranium, meaning that far more material would have to be diverted or stolen to obtain the required amount of Pu for a weapon.

The footnotes in a few pages are in the original.

Our study of this problem leads us to the following four principal recommendations: 
1. A New Weapons and Fissile Materials Regime. We recommend that the United States work to reach agreement with Russia on a new, reciprocal regime that would include:

(a) declarations of stockpiles of nuclear weapons and all fissile materials;

(b) cooperative measures to clarify and confirm those declarations;

(c) an agreed halt to the production of fissile materials for weapons; and

(d) agreed, monitored net reductions from these stockpiles.

Monitoring of warhead dismantlement and commitment of excess fissile materials to non-weapons use or disposal, initially under bilateral and later under international safeguards, would be integral parts of this regime, as would some form of monitoring of whatever warhead assembly continues.

2. Safeguarded Storage. We recommend that the United States and Russia pursue a reciprocal regime of secure, internationally monitored storage of fissile material, with the aim of ensuring that the inventory in storage can be withdrawn only for non-weapons purposes.

3. Long-Term Plutonium Disposition. We recommend that the United States and Russia pursue longterm plutonium disposition options that:

(a) minimize the time during which the plutonium is stored in forms readily usable for nuclear weapons;

(b) preserve material safeguards and security during the disposition process, seeking to maintain the same high standards of security and accounting applied to stored nuclear weapons;

(c) result in a form from which the plutonium would be as difficult to recover for weapons use as the larger and growing quantity of plutonium in commercial spent fuel; and

(d) meet high standards of protection for public and worker health and for the environment.

The two most promising alternatives for achieving these aims are:

- fabrication and use as fuel, without reprocessing, in existing or modified nuclear reactors; or

- vitrification in combination with high-level radioactive waste.

A third option, burial of the excess plutonium in deep boreholes, has until now been less thoroughly studied than have the first two options, but could turn out to be comparably attractive.

4. All Fissile Material. We recommend that the United States pursue new international arrangements to improve safeguards and physical security over all forms of plutonium and HEU worldwide. In particular, new cooperative efforts to improve security and accounting for all fissile materials in the former Soviet Union should be an urgent priority.

Because plutonium in spent fuel or glass logs incorporating high-level wastes still entails a risk of weapons use, and because the barrier to such use diminishes with time as the radioactivity decays, consideration of further steps to reduce the long-term proliferation risks of such materials is required, regardless of what option is chosen for disposition of weapons plutonium. This global effort should include continued consideration of more proliferation-resistant nuclear fuel cycles, including concepts that might offer a long-term option for nearly complete elimination of the world's plutonium stocks.

Plutonium customarily used in nuclear weapons (weapons-grade plutonium) and plutonium separated from spent reactor fuel (reactor-grade plutonium) have different isotopic compositions. Plutonium of 
virtually any isotopic composition, however, can be used to make nuclear weapons. Using reactor-grade rather than weapons-grade plutonium would present some complications. But even with relatively simple designs such as that used in the Nagasaki weapon - which are within the capabilities of many nations and possibly some subnational groups - nuclear explosives could be constructed that would be assured of having yields of at least 1 or 2 kilotons. Using more sophisticated designs, reactor-grade plutonium could be used for weapons having considerably higher minimum yields. Thus, the difference in proliferation risk posed by separated weapons-grade plutonium and separated reactor-grade plutonium is small in comparison to the difference between separated plutonium of any grade and unseparated material in spent fuel.

Choices regarding the fissile materials from dismantled weapons may also affect and be affected by civilian nuclear power programs, a topic that depends on economic, political, and technical factors outside the scope of this study. In some countries, nuclear power programs already include the use of plutonium in the fuel loaded into reactors. But the amount of weapons plutonium likely to be surplus is small on the scale of global nuclear power use - the equivalent of only a few months of fuel for existing reactors - and it is not essential to the future of civilian nuclear power. There is thus no reason that disposition of this weapons plutonium should drive decisions on the broader questions surrounding the future of nuclear power.

A cutoff of production of weapons materials would require monitoring of enrichment and reprocessing facilities. Still greater confidence could be achieved if all fuel cycle facilities were monitored. These tasks could be carried out by bilateral or international monitors (or both), using means that have met international acceptance in nonproliferation verification. Continued production of HEU for naval reactors and tritium for nuclear stockpile maintenance would introduce some complications, but these could readily be addressed through careful design of the agreement and the monitoring system.

The United States is no longer producing plutonium or HEU for weapons. Russia has also ceased production of HEU for weapons, but is still operating plutonium production reactors and separating the resulting weapons-grade plutonium. The Russian government asserts that these reactors provide necessary heat and power to surrounding areas, and that the fuel must be reprocessed for safety reasons. The United States has begun discussions with Russia about assistance in converting these reactors so that separated weapons plutonium is not generated, or in providing alternate power sources, but these discussions remain embryonic.

Risks of Recovery - The "Spent Fuel Standard." A third key security criterion for judging disposition options is the risk of recovery of the plutonium after disposition. We believe that options for the longterm disposition of weapons plutonium should seek to meet a "spent fuel standard" - that is, to make this plutonium roughly as inaccessible for weapons use as the much larger and growing quantity of plutonium that exists in spent fuel from commercial reactors. Options that left the plutonium more accessible than these existing stocks would mean that this material would continue to pose a unique safeguards problem indefinitely. Conversely, the costs, complexities, risks, and delays of going beyond the spent fuel standard to eliminate the excess weapons plutonium completely, or nearly so, would not be justified unless the same approach were to be taken with the global stock of civilian plutonium. Over the long term, however, steps beyond the spent fuel standard will be necessary - for both the weapons plutonium and the larger civilian stock - as described below.

Long-term steps will be needed to reduce the proliferation risks posed by the entire global stock of plutonium, particularly as the radioactivity of spent fuel decays. Options for reducing these risks could include placement of spent fuel in geologic repositories, or pursuit of fission options that would burn existing plutonium stocks nearly completely. A variety of reprocessing-oriented reactor options have been proposed for this mission, ranging from the use of standard LWRs to challenging concepts such as accelerator-based conversion. The costs of these approaches would be in the tens or hundreds of billions 
of dollars, and the time scales would be many decades or centuries, depending on the choice of options. These technologies can only be realistically considered in the broader context of managing the future of nuclear power to provide energy while minimizing the risk of nuclear proliferation, an important task that is beyond the scope of this committee. To further refine these concepts, research on fission options for near-total elimination of plutonium should continue at the conceptual level.

Although all the plausible disposition options will take many years to implement, it is important to begin now to build consensus on a road map for decision. Such a road map would provide guidelines for the necessary national and international debate to come, focus further efforts on those options most likely to minimize future risks, and provide plausible end points for the process that the near-term steps will set in motion. Research and development should be undertaken immediately to resolve the outstanding uncertainties facing each of the options.

Several kilograms of separated weapons-grade plutonium and a somewhat larger amount of "reactorgrade" plutonium - a minuscule fraction of the world stock - would be enough to build a nuclear weapon. Thus, the plutonium in a truckload of spent fuel rods from a typical power reactor is enough for one or more nuclear weapons. The plutonium stored at a typical civilian reactor site or reprocessing plant is enough for hundreds of weapons.

Plutonium customarily used in nuclear weapons (weapons-grade plutonium) and plutonium separated from spent reactor fuel (reactor-grade plutonium) have different isotopic compositions. Plutonium of virtually any isotopic composition, however, can be used to make nuclear weapons. ${ }^{y}$ Using reactor grade rather than weapons-grade plutonium would present some complications. But even with relatively simple designs such as that used in the Nagasaki weapon - which are within the capabilities of many nations and possibly some subnational groups - nuclear explosives could be constructed that would be assured of having yields of at least 1 or 2 kilotons. With more sophisticated designs, reactor-grade plutonium could be used for weapons having considerably higher minimum yields. Thus, the difference in proliferation risk posed by separated weapons-grade plutonium and separated reactor-grade plutonium is small by comparison to the difference between separated plutonium of any grade and unseparated material in spent fuel (see "Reactor-Grade and Weapon-Grade Plutonium in Nuclear Explosives," p. 32.)

Unseparated material, however, also poses some risk. The chemistry for separating plutonium from spent fuel is described in the open literature, and the essential technologies are available on the open market. Although separating plutonium on a commercial scale at competitive prices is difficult and costly, a potential proliferator could use a much simpler and less costly facility to extract enough material for a few weapons. Moreover, the intense radioactivity that initially makes the fuel effectively impossible to handle without remote-handling equipment decays substantially over the decades after the fuel leaves the reactor. (See "How Accessible Is Plutonium in Spent Fuel?" in Chapter 6, p. 150.) Plutonium, whether in "military" or "civilian" stockpiles, and whatever its physical, chemical, or isotopic form, must be strictly safeguarded.

y. (Footnote 10 in original) An exception is Plutonium-238 (Pu-238), which generates too much heat to make fashioning a weapon from it practicable. $\mathrm{Pu}-238$ is a rare and difficult-to-produce isotope, however, used primarily for powering certain types of space probes. Similarly, it would be difficult to fashion a workable weapon of $\mathrm{Pu}-242$, another relatively rare isotope. 
Although plutonium and HEU can both be used to make nuclear weapons, there are several differences between them, of which two are particularly important here. The first is that HEU can be diluted with other, more abundant, naturally occurring isotopes of uranium to make low-enriched uranium (LEU), which cannot sustain the fast-neutron chain reaction needed for a nuclear explosion. ${ }^{z}$ LEU is the fuel for most of the world's nuclear power reactors. In contrast, plutonium cannot be diluted with other isotopes of plutonium to make it unusable for weapons. "Re-enriching" LEU to the level needed for weapons requires complex enrichment technology to which most potential proliferators do not have access, while separating plutonium from other elements with which it might be mixed in producing fresh reactor fuel requires only straightforward chemical processing. Thus, management of plutonium in any form requires greater security than does the management of LEU.

The Spent Fuel Standard. Options for the long-term disposition of weapons plutonium should seek to meet a "spent fuel standard" - that is, to make this plutonium roughly as inaccessible for weapons use as the much larger and growing stock of plutonium in civilian spent fuel. Options that left the weapons plutonium more accessible would mean that this material would continue to pose a unique safeguards problem indefinitely. Conversely, the costs, complexities, risks, and delays of going beyond the spent fuel standard to eliminate the excess weapons plutonium completely or nearly so would not offer substantial additional security benefits unless society were prepared to take the same approach with the global stock of civilian plutonium.

This standard, if accepted, has a profound impact on the choice of long-term disposition options. Approaches that would leave the plutonium in a form substantially more accessible for recovery and use in weapons than plutonium in commercial spent fuel can be rejected, and substantially costlier, riskier, or slower options for eliminating the weapons plutonium or making it less accessible than plutonium in spent fuel should be considered only in the larger context of similar treatment of all of the world's plutonium stock.

Beyond the Spent Fuel Standard. The spent fuel standard should not be interpreted as an endorsement of today's standards of management for plutonium in spent fuel, however. Although substantially less accessible for use in weapons than separated plutonium, plutonium in spent fuel does pose a security risk, and that risk increases with time, as noted above. Further steps should be taken to reduce the proliferation risks posed by all of the world's plutonium stocks, military and civilian, separated and unseparated; the need for such steps exists already, and will increase with time (see Chapter 6).

Footnote 30 of original document: In April 1977 the Carter administration announced its decision "to defer indefinitely the commercial reprocessing and recycling of the plutonium produced in U.S. nuclear power programs" (PresidentialDocuments - Jimmy Carter, Vol. 13, no. 15, April 18, 1977). An influential analysis that provided part of the technical basis for that decision is Spurgeon M. Keeny, Jr., Nuclear Power: Issues and Choices, Report of the Nuclear Energy Policy Study Group (Cambridge, Mass.: Ballinger Publishing Company, 1977).

The risks of theft or diversion associated with a particular step in this process depend on four classes of factors:

z . (Footnote 11 in original) Natural uranium includes only 0.7 percent Uranium-235 (U-235), with almost all of the remaining 99.3 percent being U-238, whose atoms will not sustain a nuclear chain reaction. (Isotopes are different types of the same chemical element having differing numbers of neutrons 92 protons and 143 neutrons in U-235, and the same number of protons but 146 neutrons in U-238.) To sustain the chain reaction needed for a nuclear explosion, the concentration of U-235 must be greatly increased, a process known as enrichment. Typical weapons-grade uranium is more than 90 percent U- 235 . Because the various isotopes of an element are essentially identical chemically, enrichment of the fissile isotopes requires techniques that are costly and time-consuming, and for which the technology is not widely available which provides one of the primary technical barriers to nuclear proliferation. Chain reactions in power reactors, by contrast, can be and have been sustained with natural uranium, although most reactors today use LEU containing 3-5 percent U-235. 
1. The state of the plutonium, including:

a) its chemical form (for example, plutonium metal, oxide, carbide, or nitrate, of which metal is most convenient);

b) its isotopic composition (the fraction of plutonium-239 (Pu-239), the most attractive isotope for bomb making, versus the fractions of $\mathrm{Pu}-240, \mathrm{Pu}-241, \mathrm{Pu}-242$, and $\mathrm{Pu}-238$ );

c) any admixture of impurities (such as other metals, oxides, or carbides; fission products; or other neutron absorbers, which, variously, affect chemical processing requirements and radiological hazard to bomb-makers); and

d) its configuration (for example, part of an assembled warhead, intact pit, deformed pit, ingot, powder, ingredient of fuel element).

2. Stockpiles and transportation risks, namely:

a) inventories or annual throughputs (as appropriate) of the various facilities storing or handling plutonium;

b) the amount of time the inventories remain in the step in question and the duration of the throughputs; and

c) the number of times plutonium is transported from place to place (when the barriers, described below, are likely to be smaller), and the distance and duration of these trips.

3. Barriers to the theft or diversion, namely:

a) barriers inherent in the form of the material (for example, dilution, measured by the percentage of plutonium in the mixture, and gamma radiation dose, measured in roentgen-equivalent-man (rem) per hour at a specified time and distance);

b) engineered barriers (for example, massive containers, vaults, buildings, fences, special transport vehicles, detectors, alarms);

c) geographic and geologic barriers (for example, site isolation, difficult terrain, burial depth, difficulty of excavation and tunneling); and

d) institutional barriers (for example, proximity and capability of guard forces, intensity and reliability of monitoring).

4. Characteristics of the threat, including:

a) potential complicity of the custodial organization or of individuals within it;

b) capabilities of attacking forces (numbers, weapons, training, organization, determination) in the case of forcible theft; and

c) knowledge, skills, money, technology, and organization available to the prospective bombmakers.

Table 3-1 of the original lists "Format for Characterizing Security Risks of a Disposition Approach"

Attractiveness of $\mathrm{Pu}$ at this step in

Initial form 
Final form

\section{Quantitative Factors}

Inventory through-Put ( $\mathrm{kg} \mathrm{Pu}$ or $\mathrm{kg} \mathrm{Pu} / \mathrm{year})$

Residence Time or Dharation (years)

Dilution (kg of material per $\mathrm{kg}$ Pu)

Gamma Dose, Distance (rem/hr-meter)

Vulnerability (based on threat barrier interactions) with respect to threat of

\section{Covert Division}

Forcible Theft

Covert Theft

The report then replicates Table 3-2, "Attractivensess Levels and Safegta"ds Categories from DOE Orde" $5633.31^{\prime \prime}$

TABLE 3-2 Attractiveness Levels and Safeguards Categories from DOE Order 5633.31

\begin{tabular}{|c|c|c|c|c|c|c|c|c|c|}
\hline \multirow{3}{*}{ Type of Material } & \multirow{3}{*}{$\begin{array}{l}\text { Atractiveness } \\
\text { Level }\end{array}$} & \multicolumn{8}{|c|}{$\begin{array}{l}\text { Safeguands Category }(\mathrm{f}=\mathrm{greatest} \text { concem }) \\
\text { Versus Quantity of Contained Material }(\mathrm{kg})\end{array}$} \\
\hline & & \multicolumn{4}{|c|}{ Pus or U-233 } & \multicolumn{4}{|c|}{ U.235 } \\
\hline & & 1 & II & HII & IV & 1 & 站 & III & IV \\
\hline Weapons" & A & \multicolumn{4}{|c|}{ Any quantity is Category I } & \multicolumn{4}{|c|}{ Any quantity is Category I } \\
\hline Pure Products" & B & $>2$ & $0.4-2$ & $0.2-0.4$ & $<0.2$ & $>5$ & 1.5 & 0.4-1 & $<0.4$ \\
\hline High-grade materials ${ }^{e}$ & C & $>6$ & $2-6$ & $0.4-2$ & $<0.4$ & $>20$ & 6.20 & $2 \cdot 6$ & $<2$ \\
\hline Low-grade materials ${ }^{d}$ & D & NA & $>16$ & $3-16$ & $<3$ & NA & $>50$ & $8-50$ & $<8$ \\
\hline All other materials ${ }^{e}$ & E & \multicolumn{4}{|c|}{ any reportable quantity is Category IV } & \multicolumn{4}{|c|}{ any reportable quantity is Category IV } \\
\hline
\end{tabular}

NOTE: Reportable quantities are $1 \mathrm{~g}$ of $\mathrm{Pu}-239$ to $\mathrm{Pu}-242$ and enriched uranium, $0.1 \mathrm{~g}$ of $\mathrm{Pu}-238$, NA $~$ nor applicable.

"Assessembled weapons and test devices.

"Pits, major components, bullous, ingots, recastable motal, directly corvertible materials.

'Cerbides, oxides, solutions of $>25 \mathrm{~g}$ L, nitrases, etc., fucl elements and assenbblies, aljoys and mixtures, UF, or UF, at S4G5 or more enrichment.

SSolutions of 1-25 g/, process residues requiring extensive reprocessing, moderately imadiated maierial, Pu-238 (except in waste). UF, of UF, at 20-50\% entichuent.

'Highly imatiated foms, solutions of <1 g/L, uranium in any form and quantity containing greater than $20 \%$ U-235. 
TABLE 3-3 Some Security-Related Characteristics of Plutonium in Different Forms

\begin{tabular}{|c|c|c|c|c|c|c|c|}
\hline \multirow{2}{*}{\multicolumn{2}{|c|}{ Form }} & \multirow{2}{*}{$\begin{array}{l}\text { Mass } \\
\text { per } \\
\text { Item } \\
\text { (kg) }\end{array}$} & \multirow{2}{*}{$\begin{array}{l}\text { Max. } \\
\text { liem } \\
\text { Dim. } \\
\text { (cm) }\end{array}$} & \multirow{2}{*}{$\begin{array}{c}\mathrm{Pu} \\
\text { per Item } \\
(\mathrm{kg})\end{array}$} & \multirow{2}{*}{$\begin{array}{c}\mathrm{Pu} \\
\text { Conc. } \\
\text { (kg/ } \\
\mathrm{kg})\end{array}$} & \multicolumn{2}{|c|}{$\begin{array}{l}\text { Gamma } \\
\text { Dose Rate } \\
\text { (rem/h) at }\end{array}$} \\
\hline & & & & & & Surface & 1 Meter \\
\hline \multicolumn{2}{|c|}{ Intact pit (WPu metal) } & ca. 4 & ca. 10 & $\mathrm{ca} .4$ & 1 & 0.8 & 0.002 \\
\hline \multirow{2}{*}{\multicolumn{2}{|c|}{$\begin{array}{l}\text { RPu metal sphere, } \delta \text {-phase } \\
\mathrm{PuO}_{2} \text { powder, WPu }\end{array}$}} & 6 & 9 & 6 & 1 & 17 & 0.03 \\
\hline & & \multicolumn{3}{|c|}{ (powder@1 g/ $\mathrm{cm}^{3}$ ) } & 0.88 & 1 & 0.009 \\
\hline \multicolumn{2}{|c|}{ Same, RPu } & \multicolumn{3}{|c|}{ (powder@1 g/ $/ \mathrm{cm}^{3}$ ) } & 0.88 & 20 & 0.2 \\
\hline \multicolumn{2}{|c|}{ MOX fuel pellet, WPu } & 0.006 & 1 & $3 \times 10^{-4}$ & 0.05 & 0.05 & $1 \times 10^{-6}$ \\
\hline \multicolumn{2}{|c|}{ Same, RPu } & 0.006 & 1 & $3 \times 10^{-4}$ & 0.05 & 1 & $2 \times 10^{-5}$ \\
\hline \multicolumn{2}{|l|}{ MOX fuel rod, WPu } & 2.5 & 410 & 0.1 & 0.04 & 0.03 & $1.4 \times 10^{-4}$ \\
\hline \multicolumn{2}{|l|}{ Same, RPu } & 2.5 & 410 & 0.1 & 0.04 & 0.7 & $3 \times 10^{3}$ \\
\hline \multicolumn{2}{|c|}{ MOX fuel assembly, WPu } & 658 & 410 & 25 & 0.038 & 0.03 & $3 \times 10^{-3}$ \\
\hline \multicolumn{2}{|c|}{ Same, RPu } & 658 & 410 & 25 & 0.038 & 0.7 & 0.06 \\
\hline \multicolumn{2}{|c|}{ MHTGR WPu fuel block } & 100 & 80 & 0.8 & 0.008 & 0.5 & 0.02 \\
\hline \multicolumn{8}{|c|}{ Irradiated MOX fuel assembly, WPu } \\
\hline \multirow[t]{4}{*}{$0.4 \mathrm{MWd} / \mathrm{kgHM}$, } & 2 years & 658 & 410 & 23 & 0.035 & 50,000 & 4,500 \\
\hline & 10 years & 658 & 410 & 23 & 0.035 & 440 & 40 \\
\hline & 30 years & 658 & 410 & 23 & 0.035 & 190 & 17 \\
\hline & 100 years & 658 & 410 & 23 & 0.035 & 37 & 3 \\
\hline \multirow[t]{3}{*}{$40 \mathrm{MWd} / \mathrm{kgHM}$, } & 10 years & 658 & 410 & 18 & 0.027 & 4,4000 & 4,000 \\
\hline & 30 years & 658 & 410 & 18 & 0.027 & 20,000 & 1,800 \\
\hline & 100 years & 658 & 410 & 18 & 0.027 & 4,000 & 360 \\
\hline \multirow[t]{3}{*}{$50 \mathrm{MWd} / \mathrm{kgHM}$, } & 10 years & 658 & 410 & 9 & 0.014 & 55,000 & 5,000 \\
\hline & 30 years & 658 & 410 & 9 & 0.014 & 25,000 & 2,300 \\
\hline & 100 years & 658 & 410 & 9 & 0.014 & 5,100 & 460 \\
\hline \multicolumn{8}{|c|}{ Borosilicate glass log with } \\
\hline \multicolumn{2}{|c|}{ Small, $2 \%$ Pu, $20 \%$ HLW } & 250 & 50 & 4 & 0.02 & \multicolumn{2}{|c|}{ not calculated } \\
\hline \multicolumn{2}{|c|}{ Large, $2 \% \mathrm{Pu}, 20 \% \mathrm{HLW}$} & 2,200 & 300 & 34 & 0.02 & 5,000 & 900 \\
\hline \multicolumn{2}{|c|}{ Same, +10 years } & 2,200 & 300 & 34 & 0.02 & 4,000 & 720 \\
\hline \multicolumn{2}{|c|}{ Same, +30 years } & 2,200 & 300 & 34 & 0.02 & 2.500 & 450 \\
\hline \multicolumn{2}{|c|}{ Same, +100 years } & 2,200 & 300 & 34 & 0.02 & 500 & 90 \\
\hline
\end{tabular}

NOTE: Max. $=$ maximum, dim. $=$ dimension, conc. $=$ concentration; WPu $=$ weapons plutonium, assumed to contain 0.2 weight percent americium-241 (from initial $0.4 \% \mathrm{Pu}-241$, aged 14 years): $\mathrm{RPu}=$ reactor plutonium, assumed to contain 4 weight percent anericium-24I (from initial 9\% Pu-241, aged 12 years): $\delta$-phase $=$ delta-phase, one of the six crystalline phases in which plutonium occurs (the two most cornmonly mentioned in connection with nuclear weapons are alpha phase (density 19.6 $\mathrm{g} / \mathrm{cm}^{3}$ ) and delta phase (density $\left.15.7 \mathrm{~g} / \mathrm{cm}^{3}\right)$ ): MOX = mixed-oxide: MHTGR = modular hightemperature gas-cooled reactor, $\mathrm{MWd} / \mathrm{kgHM}=$ megawatt-days (of thermal energy output) per kilogram of heavy metal; HLW = high-level waste. All characteristics for intact pits are for illustrative purposes only; actual dimensions are classified. 
Signals Relating to Civilian Nuclear Fuel Cycles. The goal of long-term disposition should be not only to ensure that the plutonium from dismantled weapons is not reused in weapons, but also to reduce net security risks from all fissile materials. Thus, policymakers must be attentive to possible indirect effects that the choice of disposition options might have on the proliferation risks posed by other fissile materials in the world, as well as its direct effects on the surplus weapons material. The political signals sent by the choice of particular disposition approaches might encourage the development and use of more proliferation-resistant nuclear fuel cycles; encourage the use of more proliferation-prone nuclear fuel cycles; or serve to set a standard for improved safeguards and security for other fissile materials.

Under the Carter administration, the United States decided not to reprocess civilian plutonium or pursue plutonium fuel cycles, and launched a major international effort to convince other countries that such separated plutonium fuel cycles were uneconomical and posed significant proliferation risks. Elements of that policy were incorporated in the Nuclear Non-Proliferation Act of 1978, which remains U.S. law. Although the Reagan and Bush administrations reversed the Carter administration's opposition to domestic use of separated plutonium, for economic reasons none has ensued. Both of these administrations continued to strongly oppose plutonium separation in countries judged to pose proliferation risks, while raising no objections to continuing plutonium separation programs in Japan and Europe. On September 27, 1993, the Clinton administration announced a nonproliferation initiative that makes clear that, while the United States will not interfere with reprocessing in Japan and Europe, "the United States does not encourage the civil use of plutonium and, accordingly, does not itself engage in plutonium reprocessing for either nuclear power or nuclear explosive purposes." The initiative called for an exploration of "means to limit the stockpiling of plutonium from civil nuclear programs. "[Clinton's 1993 statement]

Given this background, policymakers will have to take into account the fact that choosing to use weapons plutonium in reactors would be perceived by some as representing generalized U.S. approval of separated plutonium fuel cycles, thereby compromising the ability of the U.S. government to oppose such fuel cycles elsewhere. Conversely, choosing to dispose of weapons plutonium without extracting any energy from it could be interpreted as reflecting a generalized U.S. government opposition to plutonium recycle. Either choice could have an impact on fuel cycle debates now under way in Japan, Europe, and Russia.

\section{Box on pages 150-151: HOW ACCESSIBLE IS PLUTONIUM IN SPENT FUEL?}

The goal of making weapons plutonium as inaccessible for weapons use as plutonium in commercial spent fuel raises the obvious question: How accessible is the plutonium in spent fuel?

The answer depends on how one answers a prior question: Accessible to whom? There are three main classes of possibilities: (i) countries with established reprocessing capabilities; (ii) countries without such capabilities, but with spent fuel in their possession; and (iii) countries or subnational groups without significant nuclear programs, who would have to acquire spent fuel before they could begin recovering the plutonium.

Four primary factors affect the usefulness of civilian spent fuel as a potential weapon material: (1) the intense radioactivity of the fission products in the fuel (which decays with time); (2) the need for chemical separation of the plutonium from the fuel (which must be done by remotely operated equipment as long as the fuel remains intensely radioactive); (3) the isotopic composition of the plutonium (reactorgrade plutonium being a less desirable weapons material than weapons-grade plutonium); and (4) if the party in question does not own the spent fuel, the difficulty of acquiring it.

For countries with established military or commercial reprocessing capabilities, the need to separate plutonium from spent fuel would pose effectively no barrier at all to recovering enough material for one or a few nuclear weapons, and recovering more would be only a matter of time and cost. Countries with 
such sophisticated nuclear technology, however, might choose to produce weapons-grade plutonium instead, as has every nation that has produced plutonium-based nuclear explosives to date.

For countries with no established reprocessing capability, recovering plutonium from spent fuel would be more difficult. All the essential processes are authoritatively described in the open literature, however, and the requisite technologies are available on the open market. Indeed, rather than building the large and expensive facilities needed to separate plutonium on a commercial scale, a potential proliferator could rely on simple and relatively low-cost facilities, designed to separate enough plutonium for a few weapons, with little attention to safety and health. Such a facility could in principle be built in an unexceptional warehouse-sized building. All the chemicals involved are widely available, used for a variety of other industrial purposes. Significant engineering skill and experience would be required, however. The workers at such a simple facility would probably receive radiation doses large enough to increase their risk of cancer, but not to cause immediate illness. This might not be a sufficient deterrent, however. By far the greatest difficulties would arise from the need, because of the radioactivity, to carry out all the main steps with remotely operated equipment.

If the facility had been built ahead of time and the procedures practiced (though without actual spent fuel available for realistic tests), in principle the time needed to separate the requisite amount of material might be only days or weeks if all went according to plan. In practice, however, the time needed is likely to be longer. The IAEA's Standing Advisory Group on Safeguards Implementation has estimated that the time required to convert plutonium in spent fuel into a weapon would be one to three months, compared to seven to ten days for metallic plutonium.

Although the processes and technology of reprocessing are unclassified, the experience gained in actually operating reprocessing plants is not widely available. As with other chemical engineering processes, many countries' initial attempts at reprocessing have encountered unexpected difficulties. Thus, there would be no guarantee of success in separating plutonium without substantial testing and practice. Such testing would greatly extend the time required.

The proliferation risk posed by spent fuel grows with time as its radioactivity becomes less intense. Fifteen years after leaving the reactor, the dose rate from a spent fuel assembly irradiated to a typical burnup would be more than 2,000 rads per hour at 1 meter from the center of the bundle, and ten times less than that after one year; 5 meters away, the dose would be only 200 rads, meaning that a person could stand 5 meters from such an assembly, unprotected, for more than an hour without receiving a lethal dose of radiation. After 15 years, the radioactivity declines by 50 percent every 30 years. How long it would take to reach the point at which remote processing, the largest single obstacle to plutonium recovery, would no longer be needed depends on how much radiation the workers in the facility would be willing to tolerate and what precautions were taken to protect them. Both the U.S. Nuclear Regulatory Commission and the IAEA consider materials emitting more than 100 rads per hour at 1 meter to be sufficiently selfprotecting to require a lower level of safeguarding (though the adequacy of that standard should be reexamined). Spent fuel of typical burnup would take more than 100 years to decay to this dose rate.

End of box on pages 150-151

\subsubsection{OTA, "Technical Options for the Advanced Liquid Metal Reactor," report OTA-BP-ENV-126, May 1994.}

This report uses Argonne's "self-protecting" terminology and seems to avoid saying definitively whether ALMR/IFR pyroprocessing would or would not violate the Clinton 1993 policy as the report refers to "may are concerned" and other such language. But, on balance, it comes down on the side opposing the ALMR/IFR on the basis of proliferation concerns, even with "self-protecting" plutonium. Of course, the 
OTA provided analysis and recommendations for Congress; it did not set policy nor interpret it for the Executive Branch.

The footnote below is in the original report. The numbered references in the original have been replaced with the actual citation.

This [fuel] ingot will contain up to 70 percent plutonium and 30 percent uranium and other actinides, as well as a minor amount of rare earth (lanthanide) fission products. Although the lanthanides contribute less than 1 percent of the mass, along with certain more radioactive actinide isotopes, they generate the hazardous radioactivity responsible for what the developers consider the "self-protecting" proliferation resistance of the final recycled fuel product. ${ }^{\text {aa }}$ A significant amount of the total radioactivity of the final product from the cathode processor and of the radioactive decay heat comes from the minor transuranic isotopes that are retained through the separation process. [J. Laidler, written comments, Feb 7, 1994.] One estimate is that without further purification this material would be about 10,000 times more radioactive than a similar product from conventional PUREX reprocessing. [R. G. Wymer, H. D. Bengelsdorf, G. R. Choppin, M. S. Coops, J. Guon, K. K. S. Pillay, and J. D. Williams, "An Assessment of the Proliferation Potential and International Implications of the Integral Fast Breeder Reactor," prepared by Martin Marietta International Technology Programs Division for U.S. Department of Energy and U.S. Department of State (Oak Ridge, TN: May 1992), 89 pp.]

\section{Later, the report addresses proliferation in more detail.}

Many are concerned that a U.S. emphasis on ALMR/IFR development, with its inherent reliance on nuclear fuel reprocessing, could undermine this policy and stimulate other nations to undertake plutonium reprocessing programs. In his September 1993 statement, President Clinton said that although the United States will not interfere with reprocessing in Japan or Europe, "the United States does not encourage the civil use of plutonium and, accordingly, does not itself engage in plutonium reprocessing for either nuclear power or nuclear explosive purposes." [OTA referenced Clinton's statement] If the United States breaks this long-standing norm by proceeding with the development of plutonium reprocessing technologies, other nations might be encouraged to consider LWR fuel without necessarily limiting the types of technologies used.

The example set by the United States in any decision about reprocessing for commercial reactors is likely to prove an important influence on the behavior of other countries and should be carefully considered. Setting an example for other nations has long been a primary argument for not supporting U.S. breeder reactor development. The NAS and others have warned that U.S. policy on plutonium disposition must take into account the signals sent by the choice of a particular disposition method.[National Academy of Sciences, National Research Council, Committee on International Security and Arms Control, "Management and Disposition of Excess Weapons Plutonium," 1994] For example, if the United States treated its weapons plutonium as a waste to be disposed of, this could set an important example in its desire to discourage the use of plutonium reprocessing

In summary, any nuclear technology carries with it some proliferation risks. These risks might be minimized by using inspection and safeguards regimes. However, the effectiveness of these measures is based more on political and international norms than on purely technical barriers. If the ALMR/IFR

aa. Self-protecting proliferation resistance originally referred to the intense radioactivity due to the fission products in spent nuclear fuel that makes it lethal to handle without extensive protection. This radioactivity "protects" the material from theft or division. The amount of fission products in ALMR/IFR reprocessed fuel is significantly lower than in LWR spent fuel and provides less self-protecting radiation. For this reason, radioactivity from the residual actinides becomes more important for the self-protecting aspect of ALMR/IFR reprocessed fuel compared with LWR spent fuel.[J. Laidler, written comments, Feb 7, 1994.] 
reprocessing technology were exported, the United States could not guarantee its ability to impose and enforce enduring and reliable technical barriers on other nations.

If the proliferation resistance of ALMR/IFR technology is judged from a purely technical viewpoint, its reprocessing facilities and nuclear reactor could clearly be adapted to breeder operation for producing plutonium. In addition, the technology carries with it several issues of general proliferation concern beyond whether it is designed as a breeder or a burner of plutonium. In itself, the use of reprocessing and its collocation with hot cell facilities provide some opportunity for plutonium concentration and the acquisition of plutonium for weapons. Although the ALMR/IFR system might prove more difficult to misuse for weapons production than a PUREX facility, its operation would produce a much more concentrated form of plutonium compared with spent LWR fuel, and would provide a facility (hot cell) and a technology for handling and reprocessing spent fuel into a weapons-usable form. Thus, from a purely technical viewpoint, if ALMR/IFR replaced or were developed as an alternative to PUREX-based reprocessing, it might be an incremental improvement nonproliferation. If it replaced the conventional LWR reactor with a once through fuel cycle followed by direct disposal, then it could increase the risk of proliferation.

\subsubsection{NAS1995, Committee on International Security and Arms Control, Panel on Reactor-Related Options, "Management and Disposition of Excess Plutonium: Reactor-Related Options." National Academy Press, Washington, D.C., 1995.}

President Obama's Science Advisor, John Holdren, chaired this activity. The report applies the "spent fuel standard" to various reactor-related options for disposition of excess weapons plutonium.

\section{THE SPENT FUEL STANDARD}

The panel recommends that the goal for WPu disposition operations to be undertaken in the next few decades should be to meet what this panel and the parent committee call the "spent fuel standard." This means making the excess WPu roughly as inaccessible for weapons use as the much larger and growing quantity of plutonium in spent fuel from commercial nuclear power reactors. 1 The "reactor-grade" plutonium found in commercial spent fuel, while it could be used to make nuclear bombs (NAS 1994, pp. 32-33), poses much smaller risks than separated plutonium in this regard because of the mass, bulk, and intense radiation field of the spent fuel assemblies and because of the additional technical sophistication and resources required for chemical separation of the spent fuel plutonium from the accompanying fission products and uranium.

Options for the disposition of WPu that leave it more accessible than the plutonium in spent reactor fuel would mean that the WPu would continue to pose a unique safeguards problem indefinitely. Conversely, accepting substantial costs, complexities, risks, and delays in order to go beyond the spent fuel standard to make the WPu significantly less accessible for weapons use than the plutonium in commercial spent fuel would not be justified unless the accessibility of the global stock of plutonium in spent fuel were to be similarly reduced.

\subsubsection{OTA, "Nuclear Safeguards and the International Atomic Energy Agency," report OTA-ISS-615, April 1995.}

The OTA does not establish or ratify policy, but it does examine technologies from the standpoint of existing or potential policies. It is notable that it described plutonium policy this way.

The footnotes in this subsection are themselves extracted from the original text. 
It is not certain whether "separated plutonium" from a policy standpoint in this time period meant (1) pure plutonium or (2) plutonium possibly mixed with something else such as uranium or other TRU.

- Arguing for the first interpretation is the use of language such as "separated plutonium", stockpiling of plutonium, the seeming equivalence of no "separated plutonium" with the phrase "ban on the production of weapon-usable materials" and so forth. Indeed, PUREX leads to pure plutonium. Finally, the language in the 1993 report, OTA-ISC-559, is a bit more stark as high enriched uranium and reactor-grade plutonium are discussed in such a way that implies the OTA was primarily thinking in terms of chemically pure plutonium, e.g., there is no mention of subsequent chemical processing if one obtained plutonium. Similarly, another 1993 report OTABP-ISC-115 implies "plutonium" with the concept it can be used to make a "crude nuclear weapon" without further chemical processing and Figure 4-1 of that reference states the two pathways are "Enrich uranium to weapon grade" and "Reprocess to obtain pure plutonium." (By the way, that report's text also mentions the U233 pathway from Th irradiation.)

- Arguing for the second interpretation is the claim that "Eliminating the production of separated plutonium would terminate exploration and exploitation of one fuel cycle that had been envisaged since the dawn of nuclear power: the recovery of plutonium from spent reactor fuel and the exploitation of that plutonium in either the current generation or a future generation of reactors." This claim is only true if one bans separation of plutonium even if it is recovered with uranium and/or other TRU. Because the 1995 OTA authors cited the 1994 report OTA-BP-ENV-126 on the ALMR/IFR, they were presumably aware of the concept of pyroprocessing plutonium with other transuranics, lanthanide fission products, and even $30 \%$ uranium in the product, followed by use of the product in the ALMR/IFR. This would suggest that "self-protecting" plutonium was not an escape from no "separated plutonium" and therefore the second interpretation is correct, hence the claim that no "separated plutonium" would forbid the fuel cycle noted above.

However, by this time, the ALMR/IFR was described as a burner of excess plutonium, a pathway to destroy plutonium not exploit it,[OTA-BP-ENV-126] whereas this 1995 report's text on fuel cycles was in the context of breeders.

Option: Discourage or ban the production world-wide of all material usable in nuclear weapons, even for civil applications.

Such an agreement would close the loophole in existing safeguards, and in the cutoff convention discussed immediately above, that would permit states to develop production facilities and even to stockpile weapon-usable materials under safeguards. Since the United States has long renounced pursuit of a plutonium fuel-cycle for its commercial nuclear powerplants, a ban on producing plutonium for civil purposes (one component of a ban on the production of weapon-usable material) would not affect U.S. plans for nuclear power. However, under such a ban, the United States would not be able to develop new research reactors fueled with highly enriched uranium. (Banning the production of weapon materials entirely would have no more effect on the U.S. nuclear weapon program than banning their production outside safeguards, since both would prohibit the production of nuclear material explicitly for weapon purposes.)

Although this measure would not directly affect the United States, states with substantial investment in plutonium fuel cycles, including Russia, Japan, France, and the United Kingdom, would strenuously object to it. Despite the lack of any economic incentives to do so for the foreseeable future, Japan and Russia, in particular, still have active plans to pursue a plutonium fuel cycle for their nuclear industry. This measure would prevent them from doing so.

Chapter 3 has a concise summary of four safeguard violations up to 1995 -Iraq, North Korea, Romania, and Pakistan. Later Chapter 3 makes this interesting observation: 
Rokkasho is the only reprocessing plant now envisioned to come under full-time IAEA safeguards with an annual plutonium production rate as large as a few tonnes per year. The only other civil reprocessing plants of this size now operating are in nuclear weapon states: the United Kingdom, France, and Russia.

Chapter 4 includes discussion on the fuel cycle.

\section{IMPROVEMENTS IN THE INTERNATIONAL NUCLEAR FUEL CYCLE}

Option: Work to achieve a worldwide cutoff-either voluntary or negotiated with verification provisionson production of all weapon-usable materials (highly enriched uranium and separated plutonium). ${ }^{\text {b }}$

One of the most serious weaknesses of the current regime of controls over nuclear materials is that states are permitted to produce and stockpile weapon-usable materials - highly enriched uranium or separated plutonium - as long as they are placed under safeguards. After amassing a stockpile, a state would be free to withdraw from NPT and use its materials in weapons. One way to close this loophole is to eliminate the production of highly enriched uranium or separated plutonium entirely. Such a policy goes beyond the fissionable material cutoff described earlier, which permits the continued production of these materials under safeguards for nonweapon purposes.

\section{Highly Enriched Uranium}

Highly enriched uranium (HEU) has little use in the civil sector. Although a number of research reactors were originally designed to use HEU, the RERTR (Reduced Enrichment for Research and Test Reactor) program has developed high-density, low-enriched uranium (LEU) fuels that can be substituted for HEU fuel in a number of reactor types. Many such reactors have been converted. (See discussion below on the RERTR program.) Some reactors, however, have yet to be converted, and suitable fuels for others do not yet exist.

For example, Germany is considering construction of a new HEU-fueled research reactor to produce intense beams of neutrons for materials studies. (The United States has just cancelled its plans for a similar reactor.) Conversion of this reactor to run on LEU fuel would introduce cost, performance, and schedule penalties that the project's supporters view to be unacceptable. Another civil use for HEU is for the initial fuel loading for breeder reactors, which are reactors designed to produce plutonium fuel. Under such a cutoff proposal, such reactors would not be allowed, so HEU would not be needed to develop them. (See discussion of banning plutonium, immediately below.)

Cutting off the production of HEU is more problematic for military purposes, since naval nuclear reactors run on HEU. Nuclear-weapon powers with surplus stocks of HEU may be able to draw on those stocks to fuel their nuclear-powered naval vessels for many years; otherwise, states would need to consider conversion to LEU (if possible) or abandonment of those vessels.

Monitoring a ban on the production of HEU is complicated by the fact that many enrichment technologies can be rather easily converted from LEU production to HEU production. Therefore, special means might have to be found to assure those participating in a fissionable production ban that LEU production facilities were not being converted in this way. Such means of verification might have to be more intrusive than the Hexapartite safeguards agreement already in place for centrifuge facilities (which allows only limited access to the cascade area), and might have to extend to all enrichment technologies. In many cases, these means would have to involve very short-notice inspections, such as provided for under the Hexapartite agreement. Such short notice is possible in Europe and Japan, because the IAEA has resident inspectors either in-country or able to travel there without lengthy border-crossing

bb. [footnote in original report] A brief but useful summary of the history and ramifications of various fissile cutoff proposals is contained in the National Resources Defense Council report "Non-Proliferation and Arms Control: Issues and Options for the Clinton Administration," January 1993, pp. 20-22. 
procedures. This approach may not be so easily extended to enrichment facilities elsewhere in the world, were they to be established there.

\section{Plutonium}

Eliminating the production of separated plutonium would terminate exploration and exploitation of one fuel cycle that had been envisaged since the dawn of nuclear power: the recovery of plutonium from spent reactor fuel and the exploitation of that plutonium in either the current generation or a future generation of reactors (see box 4-2). Because of its adverse implications for proliferation, the United States actively tried to discourage the use of plutonium in civil reactor programs overseas under the Carter Administration in the late 1970s. In 1984, the United States terminated the Clinch River breeder reactor program in Tennessee, and as of this writing the United States no longer operates any experimental or prototype breeder reactors. ${ }^{c c}$ However, several countries around the world still use, or say they intend to use, plutonium-based fuel cycles.

Banning the separation of plutonium would eventually foreclose the exploitation (and even the study) of the breeder reactor option. For many nuclear power proponents, such a step is unthinkable. It would be strenuously opposed, for example, by Russia, Japan, France, and possibly India, Kazakhstan, and the United Kingdom, as well as by some nuclear power proponents in the United States, which would see such a move as putting the most attractive feature of nuclear power forever out of reach. Russia has more practical reasons to oppose a ban on plutonium production: the three plutonium production reactors remaining in operation in Russia are producing steam heat and electricity for nearby towns, and are the only source of employment for skilled nuclear scientists and engineers in the area. ${ }^{\mathrm{dd}}$ At present, the spent fuel from these production reactors must be reprocessed within about two years to avoid corrosion and radioactive leakage into the spent fuel pond. At least as of now, Japan still plans to make extensive use of plutonium, having broken ground in 1994 for its large reprocessing facility at Rokkasho-mura, now envisioned to attain full operation in the middle of the next decade.

Even so, interest in breeder reactors is declining around the world, making it easier to consider banning the use of plutonium than it would have been 10 years ago (see box 4-3). A ban on the production of weapon-usable materials would be supported by those who are unwilling to allow nations to stockpile such materials under safeguards, by those who do not believe that safeguards on plutonium handling plants are adequate to ensure that plutonium is not diverted, and by those who believe that shipping

cc. [footnote in original report] For discussion of the advanced liquid metal reactor, an advanced reactor capable of being configured as a breeder, see U.S. Congress, Office of Technology Assessment, "Technical Options for the Advanced Liquid Metal Reactor," OTA-BP-ENV-126 (Washington, DC: U.S. Government Printing Office, May 1994). The reactor was terminated by Congress and the Clinton Administration in 1994.

dd. [footnote in original report] These reactors also have characteristics that give them inherent needs for reprocessing, despite the fact that the resulting plutonium, with less than 1,000 MW-days/ton burnup, is necessarily of excellent weapon grade. The reactors at Tomsk, like those at Hanford, cycle through roughly 1,200 ton of natural uranium fuel per year (as opposed to 35 tons of low-enriched uranium/year for a light-water reactor); storage facilities at the reactor are adequate for only 6 to 12 months of spent fuel (which cannot be stored for longer than two years in any case; see main text). While options for conversion to coal- or gas-fired generators are being studied, there is no infrastructure to bring in these fuels, and most such options appear to run up against budgets on the order of at least a billion dollars. Laurin Dodd, Pacific Northwest Laboratory, presentation at NRDC/FAS meeting, Washington, DC, Dec. 16-17, 1993. U.S. Vice President Gore and Russian Premier Chernomyrdin agreed in December 1993 to shut down these reactors by the year 2000 while taking steps to provide alternative energy supplies, with U.S. assistance. 
significant amounts of plutonium between nuclear facilities poses unacceptable safety and security risks even if diversions were certain to be detected. In this view, foregoing the civil use of plutonium would be the lesser of two evils. ${ }^{\text {ee }}$

Policies governing the production or use of new plutonium will influence, if not determine, the methods chosen to dispose of existing stock- piles of separated plutonium, including that recovered from dismantled nuclear weapons. Some who advocate that surplus weapon plutonium be "burned" in nuclear reactors-either as mixed-oxide fuel in existing light-water reactors, or more directly in future breedersdo so in large part to maintain interest in plutonium fuel cycles. ${ }^{\mathrm{ff}}$ Conversely, it will be difficult to pursue options for burning weapon plutonium in nuclear reactors - even in government reactors not connected with civil power production - in an environment where separation of plutonium for use in civil nuclear reactors is banned.

A variation on the option to ban the production of weapon-usable nuclear materials would be a ban on separating and stockpiling excess plutonium - any plutonium that would not be used immediately to fuel a nuclear reactor. Since the rate at which plutonium is being loaded into Japanese nuclear reactors has not kept up with the rate at which Japan now plans to import plutonium separated from the spent fuel that it had earlier shipped to European reprocessing plants, tons of separated plutonium will begin to be stockpiled on Japanese territory. Even if Japan does not give up the plutonium option, some observers have urged it to delay its own reprocessing, and to stop accepting shipments of separated plutonium from Europe, until its plans to consume plutonium catch up to its ability to produce it.

\section{A footnote to the 1995 OTA report implies a combined chemical and radiological "spent fuel standard," without using that language, as it points to the 1994 recommendations. [National Academy of Sciences, National Research Council, Committee on International Security and Arms Control, "Management and Disposition of Excess Weapons Plutonium," 1994] that "urges that separated plutonium from weapons rapidly be put into a form where it would take at least as much effort to recover the plutonium as it would to reprocess plutonium from the much larger stocks of spent fuel already existing worldwide. The report also concludes that once weapon plutonium has been converted to such a form - for example by mixing it with radioactive waste to create "artificial spent fuel," or by converting it to mixed-oxide fuel and partially burning it in a light-water reactor - there is little point to proceeding to eliminate it entirely before addressing those stocks of spent fuel as well."}

ee. [footnote in original report] As an alternative to recycling, while retaining some of the energy value of the plutonium, there has been some interest in a fuel cycle called "DUPIC" or Direct Use of Spent Power Reactor Fuel in Candu reactors. This approach envisions using spent LEU fuel directly in Candu natural uranium reactors. Canada has been pushing this as a long-term approach, and there is the possibility that countries such as South Korea might be interested in the future. The 0.9 percent $\mathrm{Pu}$ contained in the spent LWR fuel going in is reduced to 0.2 percent $\mathrm{Pu}$. The advantages of such an approach are that it gets rid of much $\mathrm{Pu}$, and what $\mathrm{Pu}$ is left has a smaller proportion than does the original spent fuel of the Pu-239 isotope that is desirable for weapons. One disadvantage is that radioactive fuel must be loaded into the Candu. More seriously, by institutionalizing the processing of spent fuel into new fuel to obtain additional energy, such a fuel cycle might still awaken interest in chemical reprocessing of full-circle spent fuel and the development of a plutonium fuel cycle.

ff. [footnote in original report] For extensive discussion of options for destroying weapon-grade plutonium in the United States and the Soviet Union, see U.S. Congress, Office of Technology Assessment, Dismantling the Bomb and Managing the Nuclear Materials, OTA-O-572 (Washington, DC: U.S. Government Printing Office, September 1993) and Committee on International Security and Arms Control, National Academy of Sciences, Management and Disposition of Excess Weapons Plutonium (Washington, DC: National Academy Press, 1994). A major recommendation of the latter study is that disposition of weapon plutonium be treated as an independent issue and not be subsumed under decisions concerning the future of nuclear power and the adoption or rejection of plutonium fuel cycles. The report urges that separated plutonium from weapons rapidly be put into a form where it would take at least as much effort to recover the plutonium as it would to reprocess plutonium from the much larger stocks of spent fuel already existing worldwide. The report also concludes that once weapon plutonium has been converted to such a form for example by mixing it with radioactive waste to create "artificial spent fuel," or by converting it to mixed-oxide fuel and partially burning it in a light-water reactor there is little point to proceeding to eliminate it entirely before addressing those stocks of spent fuel as well. 


\title{
4.1.53 W. H. Hannum, D. C. Wade, H. F. Macfarlane, and R. N. Hill, "Nonproliferation and Safeguards Aspects of the IFR," Progress in Nuclear Energy, 31 (1-2), pp. 203-217, 1997.
}

\author{
Might be the first definition of TRU conversion ratio.
}

INFCE concluded "The sensitive points in the nuclear fuel cycle were: 1) Enrichment facilities and their in-process product, and 2) separated (pure) plutonium and the facilities for such purification (PUREX) reprocessing). In response, in 1984 the U.S. undertook to develop the IFR recycle technology, which does not produce pure, separated plutonium."

For a system fueled with transuranics and U238, the "conversion ratio" (CR) is defined as the ratio of the gross production rate of plutonium and higher transuranic material from U238 to the destruction rate of this material. A conversion ratio of implies equality of production and destruction rates - in other words, self-sufficient operation requiring only periodic makeup additions of uranium. In the fast reactor context, the total quantity of transuranic material is used in the definition of conversion ratio because all transuranics are fissionable in a fast spectrum, not just the fissile isotopes as in thermal reactors."

\subsubsection{W. Forsberg, C. M. Hopper, J. L. Richter, H. C. Vantine, Definition of Weapons-Usable Uranium-233, ORNL/TM-13517, March 1998.}

Isotopic dilution is used to convert HEU containing primarily $235 \mathrm{U}$ to effectively non-weapons-usable material. The material is diluted with depleted, natural, or low-enriched uranium (LEU) until the fissile concentration is $<20 \mathrm{wt} \% 235 \mathrm{U}$. After isotopic dilution, it is defined as LEU. The dividing line between HEU and LEU is based on technical studies and has been codified into (1) U.S. Department of Energy (DOE) orders; (2) U.S. Nuclear Regulatory Commission (NRC) regulations (Code of Federal Regulations 1997a); and (3) International Atomic Energy Agency (IAEA) guidance, conventions, and agreements (IAEA 1993).

In terms of weapons designs, $233 \mathrm{U}$ is similar to WGP. The IAEA (1993) defines a Category I quantity of $233 \mathrm{U}$ in the context of safeguards as $2 \mathrm{~kg}$. This is the same amount as is defined for WGP. In contrast, a Category I quantity of HEU is $5 \mathrm{~kg}$.

The safeguards requirements and definitions are defined in the 10 CFR Part 74, "Material Control and Accounting of Special Nuclear Material," (CFR 1997a). The requirements defined by treaties between the United States and the IAEA for NRC-licensed facilities are detailed in 10 CFR Part 75, "Safeguards on Nuclear Materials-Implementation of U.S./IAEA Agreement," (CFR 1997b).

In its reports, the International Nuclear Fuel Cycle Evaluation (INFCE) (1980) Working Group 8 of the IAEA specifically recognizes $12 \mathrm{wt} \% 233 \mathrm{U}$ as the dividing line between weapons-usable and non weapons-usable $233 \mathrm{U}$.

The minimum critical mass increases rapidly as the concentration of $233 \mathrm{U}$ or $235 \mathrm{U}$ is reduced. The larger the mass of fissile material needed to build a weapon, the more difficult it is to design a weapon. At some lower enrichments and excessively large masses of uranium, it becomes effectively impossible to create a weapon. At $20 \mathrm{wt} \% 235 \mathrm{U}$, the critical mass is $\sim 750 \mathrm{~kg}$. This is far larger than the "significant quantity" of material that is defined as $25 \mathrm{~kg}$ of $235 \mathrm{U}$ contained in HEU by the IAEA Standing Advisory Group on Safeguards Implementation (Albright 1997). The significant quantity is that quantity of HEU that can be used to build a nuclear weapon.

With $20 \mathrm{wt} \% 235 \mathrm{U}$, the quantity of enriched uranium required to build a weapon would be more than a factor of ten higher than using $235 \mathrm{U}$ in weapons-grade HEU that typically contains $>90 \mathrm{wt} \% 235 \mathrm{U}$. The judgement of the weapons designers, who provided the technical input to the IAEA for formulation of the 
definition of non-weapons-usable $235 \mathrm{U}$, was that weapons with such large minimum critical masses would not be practicable to design.

The critical mass of a $20 \mathrm{wt} \% 235 \mathrm{U}$ metal sphere is $\sim 750 \mathrm{~kg}$. The critical mass of a $12 \mathrm{wt} \% 233 \mathrm{U}$ metal sphere is approximately the same.

\subsubsection{DOE, "Analysis of the Total System Life Cycle Cost of the Civilian Radioactive Waste Management Program," report DOE/RW-0510, December 1998.}

Since the enactment of the Nuclear Waste Policy Act (NWPA) in 1983 through fiscal year 1998, the Program has expended $\$ 5.9$ billion in year of expenditure dollars. The total estimate to complete the Program, from fiscal year 1999 through permanent closure of a repository, is estimated at $\$ 36.6$ billion in constant 1998 dollars. This TSLCC analysis differs from the previous TSLCC analysis published in 1995, as several key assumptions have changed. First, additional waste from U.S. Department of Energy (DOE)-owned and managed SNF and HLW and the disposition of surplus weapons plutonium have been included. Second, the repository would remain open for at least 100 years following initial waste emplacement and would have the capability to be kept open, with appropriate maintenance and monitoring, for up to 300 years. Costs are included in this analysis for 100 years of monitoring. Third, unlike the 1995 TSLCC analysis that relied heavily on the use of Multi-Purpose Canisters, this analysis provides the capability to dispose of a wide range of canistered and uncanistered SNF, as well as HLW.[letter to Director]

The total estimated future cost to complete the program is $\$ 36.6$ billion, in constant 1998 dollars from 1999 through closure and decommissioning, assumed to be in 2116 . A total of $\$ 5.9$ billion was spent on the total program through Fiscal Year 1998 in year of expenditure (YOE) dollars. Table 2 provides a summary of major CRWMS cost categories. Costs are represented in terms of areas of work scope over the life of the program in Figure 1. Figure 1 represents historical costs, both in YOE and constant 1998 dollars, and all future costs in constant 1998 dollars. The program is assumed to run from its inception in 1983 through closure and decommissioning of the repository in 2116. Major program milestones are depicted along the bottom axis of Figure 1. Subsequent sections of this TSLCC analysis provide details concerning each major cost category and key assumptions related to its cost estimation. A further breakout of costs for the CRWMS is provided in Appendix B.[section 1.2]

\subsubsection{Rob P. Rechard, "Historical Background on the Performance Assessment for the Waste Isolation Pilot Project," report SAND99-2719J, March 1999.}

In 1979, six years after selecting the Delaware Basin as a potential disposal area, Congress authorized the U.S. Department of Energy to build the Waste Isolation Pilot Plant (WIPP) near Carlsbad, New Mexico, as a research and development facility for the safe management storage, and disposal of waste contaminated with transuranic radioisotopes. In 1998, 19 years after authorization and 25 years after site selection, the U.S. Environmental Protection Agency (EPA) certified that the WIPP disposal system complied with its regulations. The EPA's decision was primarily based on the results from a performance. assessment conducted in 1996, which is summarized in the special issue of Reliability Engineering and System Safety. This performance assessment was the culmination of four preliminary performance assessments conducted between 1989 and 1992. This paper provides a historical setting and context for how the performance of the deep geologic repository at the WIPP was analyzed.' Also included is background on political forces acting on the project. 


\subsubsection{Report by the TOPS Task Force of the Nuclear Energy Research Advisory Committee (NERAC), "Annex: Attributes of Proliferation Resistance for Civilian Nuclear Power systems," October 2000.}

This is the detailed annex to the TOPS report, which is mentioned next in this document as its publication date follows the annexes.

The footnotes in this subsection are in the original report.

It should be noted that the definition of LEU for mixtures of U233 and U235 has not been established in law or in international agreements. The LEU limit for U235 in U238 is $20 \%$, and that for U233 in U238 is generally accepted at $12 \%$. A recent study by Forsberg, et al. (Definition of Weapons-Usable Uranium233, Oak Ridge National Laboratory, ORNL/TM-13517, March 1998) shows that 12\% U233 is "critically equivalent" to $20 \%$ U235 (in mixture with U238), and that the "criticality equivalency" of LEU for mixtures of $\mathrm{U} 233+\mathrm{U} 235$ in $\mathrm{U} 238$ can be expressed by the relationship:

$$
\left(\frac{1.67 U 233+U 235}{U-\text { total }}\right)<20 \%
$$

These attributes are not easily aggregated into a single measure of the effectiveness of the overall isotopic barrier. However, various national and international classifications of material attractiveness provide some guidance. HEU and all plutonium isotopic mixes ${ }^{\mathrm{gg}}$ are considered "directly usable" in weapons (although the technical sophistication required to design and produce such a weapon clearly varies with the isotopic mix). HEU ${ }^{\text {hh }}$ can be used to make a "gun-type" device, but plutonium requires an implosion design. Because the technical sophistication required to produce a gun-type device is considered less than that required to produce an implosion device, very highly enriched uranium presents a lower barrier to proliferation than plutonium.

The effectiveness of the isotopic barrier associated with HEU, as well as that associated with LEU, clearly depends on the level of enrichment. This fact is recognized in DOE Order 5633.31 where safeguard categories for various special nuclear materials are defined (i.e., plutonium, U233 and U235 with enrichments of $20 \%$ or greater). This order differentiates between high-grade U 235 (enrichment $50 \%$ or greater) and low-grade U235 (enrichment $<50 \%$ ). We extend this distinction to the evaluation of the isotopic barrier of HEU, and consider HEU having an enrichment $50 \%$ or greater to represent an insignificant barrier, and HEU with enrichment between $20 \%$ and $50 \%$ to represent a low to medium barrier to proliferation. This distinction recognizes that uranium enriched to less than $50 \% \mathrm{U} 235$ can be used in a nuclear weapon, but that more effort is needed to produce such a weapon than for enrichments at $50 \%$ or greater.

For plutonium, the critical mass varies less among the different isotopes. "Weapons-grade" plutonium has a critical mass of about $11 \mathrm{~kg}$ (alpha phase), while "reactor-grade" (containing 60\% Pu239) has a critical

gg. [footnote in original report] Except plutonium mixes with $80 \%$ (or greater) concentration of the isotope Pu238, which under IAEA guidelines are not subject to safeguards.

hh. [footnote in original report] Both U.S. and international practice considers uranium containing $20 \%$ or more U235 to be "High Enriched Uranium" requiring a higher degree of safeguards oversight. This distinction between HEU and lowenriched or LEU is arbitrary and results in an artificial discontinuity in the isotopic barrier for uranium.

ii. [footnote in original report] The isotopic content of reactor-grade plutonium varies with burnup (among other things.) Nominal burnup of uranium oxide fuels (in the range of 33 to $45 \mathrm{MWd} / \mathrm{kg}$ ) yield plutonium with slightly under $60 \% \mathrm{Pu} 239$ content. Higher burnups of uranium fuels $(75$ to $100 \mathrm{MWd} / \mathrm{kg}$ ) can reduce the Pu239 content to nearly $50 \%$. Alternate fuel compositions, such as uranium thorium mixes, taken to burnups as high as $100 \mathrm{MWd} / \mathrm{kg}$, may reduce the Pu239 content to nearly $40 \%$. Besides reducing the Pu239 content, increasing the burnup in all these fuels increases the content of Pu238, which further exacerbates weapons design. 
mass of about $13 \mathrm{~kg}$. However, the heat-generation rate and the spontaneous neutron-generation rate associated with reactor-grade plutonium can have a deleterious effect on the design and performance that increases with increasing burnup in a reactor. Thus, it is appropriate, for these classes of materials, to subdivide these categories to reflect these important issues. In the barrier summary, we have indicated $60 \%$ and $40 \% \mathrm{Pu} 239$ content as illustrative of the range of plutonium isotopics that may be achievable with current and near-term LWR fuels. Other reactor and fuel concepts may achieve markedly higher burnups with further reductions in Pu239 content. As in the discussion of HEU, the distinction between different classes of plutonium is not intended to imply that it is greatly more difficult to make a nuclear weapon from reactor-grade plutonium. ${ }^{\mathrm{jj}}$ The degree to which the various aspects of the isotopic barrier can be overcome depends on the technical sophistication of the state or group attempting to produce a nuclear weapon.

The preceding text motivates the "attribute" criteria in their methodology.

Fissionable materials commonly considered attractive to potential proliferators can thus be classified as follows:

Insignificant: I (-) Weapons-grade HEU (approximately $80 \%$ or greater $\mathrm{U}_{235}$ )

I ( + HEU between about 50 and $80 \% \mathrm{U}_{235}$

Low: $\quad$ L (-) Weapons-grade $\mathrm{Pu}(>90 \% \mathrm{Pu} 239)$

L Typical reactor-grade $\mathrm{Pu}$ (approximately 60\% Pu239)

$\mathrm{L}(+) \quad$ HEU between about 35 and $50 \% \mathrm{U}_{235}$; very-high-burnup reactor-grade $\mathrm{Pu}$ (approximately $40 \%$ or less Pu239)

Medium: $\quad$ M HEU between about 20 and $35 \% \mathrm{U}_{235}$

High: $\quad \mathrm{H} \quad$ Low-enriched $\mathrm{U}\left[\left(1.67 \mathrm{U}_{233}+\mathrm{U}_{235}\right) / \mathrm{U}_{\text {tot }}<20 \%\right]$

Very High: $\quad$ VH Natural, depleted U

Other fissionable materials (such as $\mathrm{Np}, \mathrm{Cm}$, and $\mathrm{Am}$ ) can be brought into this basic HEU or plutonium classification by comparing their critical masses, spontaneous neutron generation rates, and heating rates with those of HEU and plutonium (see Table 1).

\subsubsection{Report by the TOPS Task Force of the Nuclear Energy Research Advisory Committee (NERAC), "Technological Opportunities to Increase the Proliferation Resistance of Global Civilian Nuclear Power Systems (TOPS)," January 2001.}

The Task Force believes that there are a number of promising areas of research and development (R\&D) that can be, and should be, pursued by the United States in collaboration with other countries that are likely to enhance the proliferation resistance of existing and potential advanced nuclear power systems. It is recognized that proliferation resistance is only one of the important components of complete nuclear power systems that are in need of further research and development; others are steps that will advance economy, safety and waste disposal. Continued U.S. participation in strengthening the global nonproliferation regime will depend, in part, on the preservation of U.S. technological capabilities in the

jj. [footnote in original report] Nonproliferation and Arms Control Assessment of Weapons-Usable Fissile Material Storage and Excess Plutonium Disposition Alternatives, U.S. Dept. of Energy Report DOE/NN-0007, January 1997, pp. 3739. 
civil nuclear sector, including a strong U.S. capability to carry out realistic and well-focused nuclear energy supply research and development. In turn, achieving and preserving this capability will require both greatly increased government investment in forward looking R\&D and the application of effective selectivity in deciding which of the several competing approaches should receive priority. This is a matter of compelling significance from the perspective of achieving vital U.S. foreign policy, arms control and energy security.

The Task Force recognizes that technology can play a very important role in strengthening the overall nonproliferation regime along the following lines:

- Improving the effectiveness of surveillance, monitoring, inspection, accountancy, and physical security measures that are embedded in institutional controls;

- Devising new inherent technical features which promise to make nuclear power systems more resistant to proliferation;

- Reducing opportunities for the misuse of, or the diversion and theft from, civilian nuclear activities;

- Increasing the complexity, transparency, and cost of diverting nuclear materials for use in nuclear weapons, as well as the time it would take for a state to divert nuclear materials so as to give the international community sufficient time to detect such activity and take appropriate action;

- Reducing the accessibility of weapons-usable nuclear materials; and

- Reducing the degree to which civilian nuclear energy programs may provide opportunities for States or groups to build up expertise for potential proliferation and to acquire (overtly or covertly) technologies that could be employed for nuclear weapons programs.

- Specific technologies employed in the civilian nuclear sector are likely to have only a modest impact on the overall rate of nuclear proliferation. Historically, the preferred approach for nations seeking nuclear weapons generally has been to establish a dedicated military program to produce the nuclear material rather than attempting to divert material from internationally safeguarded nuclear facilities. Nevertheless, civilian nuclear activities can make direct or indirect contributions to the spread of nuclear weapons.

A number of such methodologies have been considered and are under development. Two such efforts, described in Appendix 2 of this report, have been examined by the Task Force to help illuminate the discussion. The first is an integrated safeguards evaluation methodology (ISEM) being developed under the U.S. support program for the IAEA safeguards system. The second, called an "attributes methodology" identifies the intrinsic, or material/technical barriers against proliferation in a given nuclear system, attempts to evaluate their effectiveness against the challenges imposed by different types of potential proliferators, and seeks to identify the needed extrinsic barriers to complement the intrinsic barriers. Other assessment methods are also under consideration.

An initial effort to apply the attributes methodology to defining the comparative features of several specific nuclear power systems was made by the TOPS Task Force. This was only done in a preliminary fashion, and the cases covered were not complete in themselves nor do they cover the full scope of systems today or under development. The primary purpose of the exercise was to help identify the major characteristics of various nuclear systems and potential R\&D needs. The systems covered in this preliminary analysis included: 
- A light water reactor (LWR) operating on a "once through" fuel cycle where the resultant spent fuel is stored for a protracted period or disposed of geologically in a nominal permanent geologic repository. This included concepts such as using non-fertile fuel and thorium-uranium fuels.

- An LWR system operating on a so-called closed fuel cycle where the fuel is reprocessed through a classic aqueous (or PUREX) system with the plutonium either recycled as MOX fuel in LWRs or kept in protracted storage pending decisions on later disposition - which might include use in fast spectrum reactors.

- A fast spectrum reactor operating in a burner or breeding mode employing an advanced recycling technology that does not involve at any stage the separation of pure plutonium.

- A postulated small modular reactor system employing a long-lived core for possible use in both advanced and developing countries.

- Two types of modular high temperature gas-cooled reactors (HTGR): a pebble bed fueled system and a fixed prismatic configuration fuel system.

In general, some of these systems would incorporate substantial intrinsic barriers to theft or diversion of nuclear material for use in nuclear weapons, while others rely more on extrinsic, institutional barriers. In the course of the discussions, some weaknesses in these barriers were identified and some R\&D programs were recommended to evaluate or address them.

It would appear that the intrinsic barriers in some systems could be strengthened by successful completion of $R \& D$, but the ongoing need to preserve the strength of extrinsic barriers has been strongly reinforced in the analysis of the Task Force to date. In addition, as an important matter, the application of extrinsic barriers to specific reactor and fuel cycle systems can be made more effective if proliferation resistance assessments, including trade-off studies between intrinsic and extrinsic measures, become an integral part of the overall design and engineering process.

\section{This report defines HEU as}

Uranium mixture containing 20 percent or more of the isotope $U-235$ or 12 percent or more of U-233.

\subsubsection{DOE, "Analysis of the Total System Life Cycle Cost of the Civilian Radioactive Waste Management Program," report DOE/RW-0533, May 2001.}

Since the enactment of the Nuclear Waste Policy Act (NWPA) in 1983 through fiscal year 2000, the Program has expended $\$ 6.7$ Billion in year-of-expenditure dollars. The total estimated cost to complete the Program, from fiscal year 2001 through permanent closure of a potential repository, is approximately $\$ 49.3$ Billion in constant 2000 dollars. This TSLCC analysis differs from the previous TSLCC analysis published in 1998, as the design basis has changed. From a cost standpoint, the major changes include waste package fabrication costs, inclusion of the titanium drip shields, increasing the ventilation rate, and changing the underground design. These changes were made to reduce system uncertainties.

\subsubsection{National Energy Policy Development Group, "National Energy Policy," May 2001.}

This is the document cited as the source of the "no separated plutonium" policy in DOE's annual reports to Congress 2003-2007 on fuel cycle options. 
The NEPD Group recommends that, in the context of developing advanced nuclear fuel cycles and next generation technologies for nuclear energy, the United States should reexamine its policies to allow for research, development and deployment of fuel conditioning methods (such as pyroprocessing) that reduce waste streams and enhance proliferation resistance. In doing so, the United States will continue to discourage the accumulation of separated plutonium, worldwide.[Page 5-22]

The United States should also consider technologies, in collaboration with international partners with highly developed fuel cycles and a record of close cooperation, to develop reprocessing and fuel treatment technologies that are cleaner, more efficient, less waste-intensive, and more proliferation resistant.[Page $5-22]$

\subsubsection{George W. Bush, "Letter to Congressional Leaders Recommending the Yucca Mountain Site for the Disposal of Spent Nuclear Fuel and Nuclear Waste," February 15, 2002.}

Dear Mr. Speaker: (Dear Mr. President:)

In accordance with section 114 of the Nuclear Waste Policy Act of 1982, 42 U.S.C. 10134 (the "Act"), the Secretary of Energy has recommended approval of the Yucca Mountain site for the development at that site of a repository for the geologic disposal of spent nuclear fuel and high level nuclear waste from the Nation's defense activities. As is required by the Act, the Secretary has also submitted to me a comprehensive statement of the basis of his recommendation.

Having received the Secretary's recommendation and the comprehensive statement of the basis of it, I consider the Yucca Mountain site qualified for application for a construction authorization for a repository. Therefore, I now recommend the Yucca Mountain site for this purpose. In accordance with section 114 of the Act, I am transmitting with this recommendation to the Congress a copy of the comprehensive statement of the basis of the Secretary's recommendation prepared pursuant to the Act. The transmission of this document triggers an expedited process described in the Act. I urge the Congress to undertake any necessary legislative action on this recommendation in an expedited and bipartisan fashion.

\subsubsection{P. Weiss, "Little-studied metal goes critical - Neptunium Nukes?," Science News. October 26, 2002.}

http://findarticles.com/p/articles/mi_m1200/is_17_162/ai_94011322/[accessed10/12/2011]

Scientists first created the artificial element neptunium in 1940, around the time they made the first atoms of plutonium. But because plutonium turned out to be so much better for nuclear weapons, researchers have paid scant attention to neptunium.

Now a team at Los Alamos (N.M.) National Laboratory has measured how much neptunium it would take to make a bomb--the element's critical mass--with far greater accuracy than ever before. From a preliminary data analysis, the investigators find that neptunium's critical mass is around 60 kilograms. The critical mass of plutonium-239 is about $10 \mathrm{~kg}$, and for uranium-235, the most widely used nuclear explosive after plutonium, it's about $50 \mathrm{~kg}$.

Commercial nuclear reactors create annually tons of neptunium mixed in with other nuclear waste. Indeed, since 1999, the International Atomic Energy Agency in Vienna has urged monitoring of neptunium. However, according to the agency, the risk of anyone making neptunium bombs from that highly radioactive waste is low because it would be so difficult to extract the isotope. 
Since its inception more than a half century ago, the U.S. nuclear-weapons program has generated about $340 \mathrm{~kg}$ of pure neptunium, says Rene G. Sanchez, who co-led the critical-mass measurement with David J. Loaiza.

"All the [pure] neptunium in this country is tracked and accounted for," says Los Alamos team member Steven D. Clement. "The question mark is other countries." Russia probably holds significant quantities of pure neptunium, he adds.

When struck by neutrons, nuclei of neptunium and other nuclear materials can fission into two smaller nuclei. Because fission releases additional neutrons, a chain reaction can take place. A critical mass produces a self-sustaining chain reaction. If controlled in a nuclear reactor, such a chain reaction can safely generate power. If uncontrolled, the chain reaction can unleash a mighty blast.

To measure neptunium-237's critical mass, the Los Alamos team cast a softball-size, 6-kg sphere of the metal that could nestle within two hemispheres of uranium. The researchers then brought the uranium hemispheres together over the course of 4 days at a carefully controlled rate.

When the hemispheres were about 3 millimeters apart, detectors recorded a steep rise in neutron production, signaling that a chain reaction was, in nuke parlance, going critical. From the neptuniumuranium assembly's critical mass, the team then calculated neptunium's individual critical mass. "When you go critical, that's when things get exciting," Clement says.

That's exactly the kind of excitement that designers of nuclear-waste repositories want to avoid. "If you're going to store it, you have to know how much you can put together and still be safe," says nuclear-safety specialist Robert D. Busch of the University of New Mexico in Albuquerque.

\subsubsection{3 "National Strategy to Combat Weapons of Mass Destruction," December 2002.}

The United States pursues a wide range of programs, including the Nunn-Lugar program, designed to address the proliferation threat stemming from the large quantities of Soviet-legacy WMD and missilerelated expertise and materials. Maintaining an extensive and efficient set of nonproliferation and threat reduction assistance programs to Russia and other former Soviet states is a high priority. We will also continue to encourage friends and allies to increase their contributions to these programs, particularly through the G-8 Global Partnership Against the Spread of Weapons and Materials of Mass Destruction. In addition, we will work with other states to improve the security of their WMDrelated materials. [Page 4]

In addition to programs with former Soviet states to reduce fissile material and improve the security of that which remains, the United States will continue to discourage the worldwide accumulation of separated plutonium and to minimize the use of highly-enriched uranium. As outlined in the National Energy Policy, the United States will work in collaboration with international partners to develop recycle and fuel treatment technologies that are cleaner, more efficient, less waste-intensive, and more proliferation-resistant.[Pages 4-5]

\subsubsection{GAO, "Nuclear Waste - Challenges to Achieving Potential Savings in DOE's High-Level Waste Cleanup Program," report GAO-03-593, June 2003.}

In considering how some stakeholders view recycling today, it is relevant to note that much of the DOE cleanup challenge stems from past reprocessing efforts, and that ... DOE's main strategy for treating high-level waste continues to include separating and concentrating much of the radioactivity into a smaller volume for disposal in a geologic repository. 
That is, DOE concentrated on concentrating waste for volume-reduction purposes.

Waste classification issues, naturally, arise in both future candidate fuel cycles as well as DOE cleanup....

DOE faces significant legal and technical challenges to realize these savings. A key legal challenge involves DOE's authority to decide that some waste with relatively low concentrations of radioactivity can be disposed of on site. This authority is being challenged in court, and a prolonged challenge or an adverse decision could seriously hamper DOE's ability to meet its accelerated schedules. A key technical challenge is that DOE's approach relies on laboratory testing to confirm separation of the waste into highlevel and low-activity portions. At the Hanford Site in Washington State, DOE plans to build a facility before integrated testing of the separation technology — an approach that has failed on other projects in the past, resulting in significant cost increases and schedule delays.

$G A O$ did not find DOE's approach satisfactory regarding waste and facility testing:

GAO recommends that DOE (1) seek clarification of its authority to designate waste as other than highlevel waste if a prolonged legal challenge occurs; (2) conduct integrated testing of waste separations components before completing a full-scale facility at the Hanford Site; and (3) ensure that DOE management practices include conducting rigorous analyses, following best practices for incorporating new technologies, and being cautious about using a concurrent design/build approach for nuclear facilities. In commenting on the report, DOE agreed to consider seeking clarification of its authority as appropriate, but said that its practices met the intent of the other two recommendations. GAO believes further improvements are needed.

This sentence was interesting, no citation given:

In 1985, President Reagan decided that a separate repository for defense waste was not needed.

This is yet another GAO report that lists relevant legal authorities, giving the author of the present report additional confidence that all relevant laws have been identified. But, if one goes into certain waste issues later in more detail, the Federal Facility Compliance Act of 1992 needs to be considered.

Under amendments the Federal Facility Compliance Act of 1992 made to the Resource Conservation and Recovery Act of 1976 (RCRA), DOE generally must develop waste treatment plans for its sites that contain mixed wastes.[42 U.S.C. $6939 \mathrm{c}$ (b)] These plans are approved by states that the Environmental Protection Agency (EPA) has authorized to administer RCRA or by EPA in states that have not been so authorized.

The DOE emphasis on volume reduction pervades this entire report.

DOE's process for dealing with its high-level waste centers on separating the various components of the waste so that the portion that is most radioactive can be concentrated into a much smaller volume. While currently all high-level waste is radioactive and dangerous, significant portions of the waste, such as contaminated water, will have low levels of radioactivity if separated from most of the radionuclides that are highly radioactive. Contaminated water currently represents 54 percent of the total waste by volume across the DOE complex.11 In overview, DOE's process generally involves separating the waste into two main streams. One, the high-level portion, will contain at least 90 percent of the radioactivity and a small portion of the waste volume. The other stream, the low-activity portion, will contain 10 percent or less of the total radioactivity but most of the waste volume. 


\subsubsection{Catherine Westfall, "Vision and reality: The EBR-II story," Nuclear News, February 2004, pp. 25-32.}

As part of this transition, on the morning of April 26, 1944, Enrico Fermi, Leo Szilard, Eugene Wigner, Alvin Weinberg and others gathered to discuss the possibilities for using nuclear fission to heat and light cities.

The April 26, 1944 memo is reproduced in its entirety in Koch2008. Per Leon Walters, presentation to the Idaho chapter of the American Nuclear Society, October 20, 2011, this 1944 meeting was quite key and quite far-sighted with regard to the technical approaches for commercial power plants. For example, consider the next three paragraphs in this 2004 article.

The scarcity of fissile material was on everyone's mind - it was agonizingly unclear at that time whether there was sufficient fissile material for usable wartime bombs. Fermi and the others therefore cast around for ways to produce maximum civilian power with minimal resources. They hit upon a novel scheme: designing a civilian power reactor that produced more fissile material than it consumed. Their plan was to place uranium-238 (or some other fertile material) near the reactor's core to capture the excess neutrons and thereby to breed new fissile fuel. They decided that such a device, which was later called a breeder reactor, would have to use fast neutrons - that is, neutrons would not be moderated as in most of the weapons materials reactors then in existence.

According to their calculations, with fast fission, enough neutrons would be created in the course of power production to hit the fertile material and create extra fissionable material. Cities could be lit and heated, while in the process, the reactor could create some fraction of its future fuel.

To minimize these needs for replacement fissile fuel, the power-per-unit fissile fuel, loading in the reactor needed to be maximized. The scientists discussed the possibility of using sodium coolant because such a reactor would have a high power density, which would require effective heat removal. Sodium coolant was an attractive choice because it is an excellent heat removal fluid having minimal interaction with neutrons.

\section{EBR-I produced the first electricity on December 20, 1951.}

EBR-II achieved criticality on September 30, 1960.

As the concept of IFR was being defined, a crucial EBR-II experiment was under way. Gerry Golden, John Sackett, and Pete Planchon - along with other Argonne engineers - considered ways to show that EBRII was inherently safe. That is, it would shut down safely even if safety systems failed to operate. This test was successfully completed in April 1986. Following a temperature rise, EBR-II regulated its own temperature and power without the use of emergency safety operations or operator intervention. Inherent safety became an important pillar of the IFR concept.

Despite EBR-II successes, in August 1994, Congress terminated the IFR, while providing $\$ 84$ million for efforts to wind down the IFR program. On September 27, 1994, EBR-II ran for the last time. As of this date, no plans for EBR-III had materialized and none have subsequently been launched. 


\subsubsection{Matthew Bunn, "Proliferation-Resistance (and Terror-Resistance) of Nuclear Energy Systems," Managing the Atom Project, Harvard University, Lecture for "Nuclear Energy Economics and Policy Analysis", April 12, 2004, http://www.ksg.harvard.edu/bcsia/atom}

\section{What is proliferation resistance?}

Definition: A nuclear energy system is proliferation-resistant if its deployment and use, on the scale and with the distribution envisioned by proponents, would not significantly increase the probability of proliferation of nuclear weapons.

- Considering the full system life cycle (including all aspects of the fuel cycle)

- Considering both intrinsic factors (e.g., difficulty of producing weapons material from material and facilities used in the system) and extrinsic factors (e.g., types of safeguards and security measures to be applied)

\section{Proliferation resistance rule of thumb}

Ask yourself: Would the U.S. (and Israeli) governments be comfortable if it was this system, rather than a once-through LWR under international safeguards, that Russia was building in Iran?

- If yes, system is clearly "proliferation-resistant."

- If no, there may still be aspects to be debated.

- (More on this case and its implications in a moment.)

Proliferation-resistance: neither side of the nuclear debate much interested

Pro-nuclear view:

- Existing safeguards provide sufficient protection against use of civilian nuclear energy for weapons - no country has ever used safeguarded nuclear material to make a bomb

- Proliferation is a political issue, not a technical one - countries that are determined to get nuclear weapons will eventually do so, regardless of technology of civilian nuclear energy system

Anti-nuclear view:

- All nuclear energy systems pose proliferation risks - relying on enrichment, producing plutonium (or at least producing neutrons that could be used to produce plutonium)

- These dangers cannot be substantially reduced without abandoning nuclear energy

A middle view:

- Real nuclear energy contribution to spread of nuclear weapons can be reduced substantially by technical and institutional measures

\subsubsection{Thomas Graham, Jr., Common Sense on Weapons of Mass Destruction, 2004.}

Egypt has a nuclear technology infrastructure, but has never pursued a weapon program. It does, however, have a chemical and biological weapon capability. Although Egypt has a peace treaty with 
Israel, it has profound misgivings about the Israeli nuclear weapon program, and in protest has refused to sign the Chemical Weapon Convention. Egypt was also reluctant to agree to a permanent NPT in 1995 for the same reason.[Page 134]

Syria has a chemical and biological weapon capability and a significant stockpile of their weapons. It also has refused to join the Chemical Weapon Convention. [Page 134]

Iraq, as is well known, had a rather advanced nuclear weapon program and was approaching the acquisition of a few crude nuclear weapons at the time of the first Gulf War. Iraq also had a vast chemical and biological weapon capability. The nuclear program was completely eliminated after the first Gulf War by the IAEA and was not resuscitated. It now appears that the stocks of chemical and biological weapons were eliminated as well, even after the 2003 conflict.[Page 134]

Iran has chemical and biological weapon programs, and - of more significance - appears to be moving toward a nuclear weapon capability while strongly asserting that it is interested only in civilian power production. Power reactors are being built for Iran by Russia that will produce spent fuel as part of the power production process, which, if not returned to Russia, could be reprocessed by Iran to produce plutonium. Iran is also building uranium-enrichment facilities, apparently at sites not declared to the IAEA and therefore in violation of their NPT-related IAEA safeguards obligations, perhaps with the purpose of making low enriched uranium for power-reactor fuel, or, perhaps for making HEU for weapons. However, after a strong intervention by the European Union, Iran has agreed to cooperate fully with the IAEA and "temporarily" suspend uranium enrichment activities. In late June, 2004 Iran gave notice that it would resume construction of centrifuges for uranium enrichment. [Page 134-135]

Libya, which reportedly some years ago tried to buy a nuclear weapon from China, decided in late 2003 to give up its weapons of mass destruction program, cooperate with the NPT and the IAEA and join the NPT. This means the elimination of its sizable chemical weapon capability and the destruction of its nascent nuclear weapon program. Libya had purchased centrifuges from the A. Q. Khan network in 1997 to enrich uranium, but this equipment never became operational. Apparently, Libya did not have scientists who knew what to do with this equipment, which has not been delivered to the United States. In 2001, North Korea reportedly delivered to Libya an amount of uranium, which if put through an enrichment process would have yielded enough HEU for one nuclear weapon. Apparently, the principal reason that Libya took the step of terminating its weapons of mass destruction program was to gain Western assistance for its flagging oil industry, although there may be more to it than that.[Page 135]

This conflict [India-Pakistan] reaches as far back into history as does the Arab-Israeli conflict. It began when the British departed in 1947, at the time of the partition of the British dominion of India, amidst great violence between the Indian Union and Pakistan. Three wars have been fought between India and Pakistan - the same number as between Israel and its Arab neighbors since the establishment of Israel in 1948. Almost as old as this confrontation is the Indian nuclear weapon program, which was first contemplated by Indian Prime Minister Jawaharlal Nehru to ensure great power status for India. This led to an Indian nuclear test in 1974, which was seen as a blow to the recently concluded NPT, and for which India was condemned by much of the world. Afterwards, India did not build weapons nor create a nuclear arsenal until after its round of five nuclear weapon tests in 1998. After this second testing of nuclear weapons, Indian Prime Minister Vajpayee left no doubt as to India's motivation: to give India the appearance of being a great power. India promptly proceeded to built a nuclear weapon stockpile and to develop missiles to deliver such weapons against Pakistan and eventually China.[Page 137]

The Pakistani nuclear weapon program began in 1965, when the first Pakistani research reactor began functioning. Pakistani Prime Minister Ali Bhutto famously said at that time that if India should acquire nuclear weapons, Pakistan would have them as well even if the people had to "eat grass." He later noted that there was a Catholic bomb, a Protestant bomb, and a communist bomb - why not an "Islamic bomb"? 
In May 1997, following India's five nuclear weapon tests, Pakistan responded with six tests - its first. Thereafter, Pakistan began building nuclear weapons and, with Chinese help, developing missiles to deliver the weapons against India. However, it should be noted that Pakistan had already built nuclear weapons in the 1980 s before it tested them - they were HEU-fueled and thus presumed reliable without testing. The actual tests in 1998 were therefore presumably a response to India rather than a design evaluation. The Pakistanis may also have worked on missiles prior to 1998. The Pakistani program developed a greater sense of urgency after the disastrous 1973 war with India, in which Pakistani forces were crushed by the Indian army and Pakistan was dismembered, with former East Pakistan become the independent state of Bangladesh.[Page 137-138]

\subsubsection{GAO, "Securing U.S. Nuclear Materials - DOE Needs to Take Action to Safely Consolidate Plutonium," report GAO-05-665, July 2005.}

There are 12-foot plutonium fuel rods that are stored at Hanford. These would have been used in FFTF and hence must be oxide fuel. In this report, GAO documents that there is really no disposition path forward, e.g., agreements between the state of South Carolina and SRS prohibit more plutonium shipped to SRS until what is there is dealt with.

DOE cannot consolidate all of its plutonium at the Savannah River Site for several reasons. First, DOE has not completed a plan to process the plutonium into a form for permanent disposition, as required by the National Defense Authorization Act for Fiscal Year 2002. Without such a plan, DOE cannot ship additional plutonium to SRS. Second, even if this plan was in place, SRS cannot currently receive all of Hanford's plutonium because it is in a form that SRS had not planned on storing. Specifically, Hanford was preparing to ship plutonium to SRS as part of its efforts to accelerate the cleanup and demolition of its closed nuclear facilities. About one-fifth of Hanford's plutonium is in the form of 12-foot-long nuclear fuel rods. Because disassembling the fuel rods would delay cleanup activities, Hanford's accelerated cleanup plan calls for shipping these rods intact to SRS inside special shipping containers. However, SRS's storage plans called for storing Hanford's plutonium in DOE's standard 5-inch-wide, 10-inch-long storage containers. SRS's storage plan assumed Hanford would disassemble the fuel rods and package the plutonium in storage containers. Despite these inconsistencies, DOE approved both Hanford's accelerated cleanup plan and SRS's plutonium storage plans. Instead of developing an integrated plan for plutonium consolidation, DOE relied upon its individual sites to independently develop plans to achieve their own goals. Although SRS's storage facility has sufficient space to store the fuel rods, several steps are necessary before DOE would be able to ship the fuel rods to SRS. These include obtaining Department of Transportation certified shipping containers for the fuel rods and completing the appropriate safety analyses and documentation for SRS's storage facility. Changes to DOE's security requirements have complicated SRS's storage plans by eliminating one facility that DOE planned to use to store plutonium. Originally, DOE had planned to use two SRS facilities to store its excess plutonium. However, both facilities would need extensive and expensive upgrades to comply with the new 2004 DBT requirements. In order to save money, DOE has, therefore, decided to use only one facility to store plutonium. Until DOE develops a plan to process the plutonium for permanent disposition, additional plutonium cannot be shipped to SRS and DOE will not achieve the cost savings and security improvements that plutonium consolidation could offer. In particular, continued plutonium storage at Hanford will cost approximately an additional $\$ 85$ million annually and will threaten that site's achievement of the milestones in its accelerated cleanup plan.

\subsubsection{George W. Bush, February 20, 2006, page 297 of 2006 presidential papers.}

And so we've got some challenges, however, in dealing with this issue. And that's why I put together what's called a global nuclear energy partnership. It's a partnership that works with countries that have 
got advanced nuclear energy programs or civilian nuclear energy programs like France and Great Britain and Japan and Russia. And here are the objectives of the partnership.

First, supplier nations will provide fuel for nonsupplier nations so they can start up a civilian nuclear energy program. In other words, a lot of countries don't know how to enrich; a handful do. And it makes sense that we share that - share the benefits of our knowledge with others - but not share the knowledge, because there's concern about proliferation.

One of the concerns you hear from the critics of expanding nuclear power is, all this will do to create proliferation concerns. Well, here's one way to address those concerns - to say, "We'll provide the fuel for you, and we'll collect the fuel from you, by the way, and after we collect the fuel from you, we need to reprocess the spent nuclear material." By reprocessing, you can continue to use the fuel base, but equally importantly, we'll reduce the amount of nuclear waste that needs to be stored.

\subsubsection{0 "The National Security Strategy of the United States of America", March 2006.}

The first objective requires closing a loophole in the Non-Proliferation Treaty that permits regimes to produce fissile material that can be used to make nuclear weapons under cover of a civilian nuclear power program. To close this loophole, we have proposed that the world's leading nuclear exporters create a safe, orderly system that spreads nuclear energy without spreading nuclear weapons. Under this system, all states would have reliable access at reasonable cost to fuel for civilian nuclear power reactors. In return, those states would remain transparent and renounce the enrichment and reprocessing capabilities that can produce fissile material for nuclear weapons. In this way, enrichment and reprocessing will not be necessary for nations seeking to harness nuclear energy for strictly peaceful purposes.[Page 20]

The second nuclear proliferation objective is to keep fissile material out of the hands of rogue states and terrorists. To do this we must address the danger posed by inadequately safeguarded nuclear and radiological materials worldwide. The Administration is leading a global effort to reduce and secure such materials as quickly as possible through several initiatives including the Global Threat Reduction Initiative (GTRI). The GTRI locates, tracks, and reduces existing stockpiles of nuclear material. This new initiative also discourages trafficking in nuclear material by emplacing detection equipment at key transport nodes.[Page 21]

We will build the Global Nuclear Energy Partnership to work with other nations to develop and deploy advanced nuclear recycling and reactor technologies. This initiative will help provide reliable, emissionfree energy with less of the waste burden of older technologies and without making available separated plutonium that could be used by rogue states or terrorists for nuclear weapons. These new technologies will make possible a dramatic expansion of safe, clean nuclear energy to help meet the growing global energy demand.[Page 29]

\subsubsection{George W. Bush, May 24, 2006, page 1007 of 2006 presidential papers.}

I understand the issue of waste, and we've got to do something about it. We've got to be wise about nuclear waste. I'm a believer that Yucca Mountain is a scientifically sound place to send the waste, and I would hope that the United States Congress would recognize that as well.

I also recognize that we can do something on a reprocessing front. And so I got our administration to commit to the Global Nuclear Energy Partnership. I think you'll find this interesting; at least I did. Under the partnership, America is going to work with nations that have already got an advanced civilian nuclear energy program, such as France and Japan and Russia, and we're going to use new technologies that 
effectively and safely recycle spent nuclear fuel. In other words, we're coming together to say, how can we do a better job of reprocessing and recycling fuel?

And the reason that's important, at least for our fellow citizens to understand, is it will reduce the amount of the toxicity of the fuel and reduce the amount we have to store. To me, it's a smart way to combine with others to reduce storage requirements for nuclear waste by up to 90 percent. It's a good way to work with other nations that are spending money on research and development as well. It's a way to, kind of, leverage up an investment.

\subsubsection{GAO, "Nuclear Waste - Plans for Addressing Most Buried Transuranic Wastes Are Not Final, and Preliminary Cost Estimates Will Likely Increase," report GAO-07-761, June 2007.}

We provided a draft of this report to DOE for its review and comment. Overall, DOE generally agreed with our findings. However, with regard to the volume of transuranic wastes intended for disposal at WIPP, DOE stated that it regularly adjusts its forecasts and does not currently project that waste volumes will exceed WIPP capacity. While we agree that DOE's current projections do not indicate WIPP capacity will fall short of future requirements, cleanup decisions are still pending at the Hanford Site and the Idaho National Laboratory, which together comprise the bulk of DOE's total inventory of buried transuranic wastes. If substantial portions of the transuranic wastes at these sites must be exhumed and disposed of off-site, WIPP's authorized capacity may be insufficient.

This report documents that DOE is disposing (permanently) of TRU waste in place at multiple sites.

DOE is still evaluating cleanup options for most of the waste at the three remaining sites - the Hanford Site, the Idaho National Laboratory, and the Los Alamos National Laboratory - where about 90 percent of DOE's transuranic wastes are buried.

This report also ties TRU waste disposal to CERCLA procedures.

\subsubsection{Anthony Andrews, "Nuclear Fuel Reprocessing: U.S. Policy Development," Congressional Research Service, RS22542, November 29, 2006; updated March 27, 2008.}

This 6-page document summarizes the evolution of policy in this arena. The major ones are included in the timeline in chapter 2 of this document. Some others that may be of interest are as follows:

1956. Lewis Strauss, then chairman of the AEC, announced a program to encourage private industry's entry into reprocessing spent nuclear fuel.

1957. The AEC expressed its intent to withdraw from providing nuclear reprocessing services for spent nuclear fuel in a Federal Register notice of March 22, 1957.

1959. The Davison Chemical Company, later called Nuclear Fuel Services, began extensive discussions with the $\mathrm{AEC}$ on commercial reprocessing.

1964. The AEC was authorized to issue commercial licenses to possess special nuclear material subject to specific licensing conditions (P.L. 88-489).

1966. The AEC granted an operating permit for commercial reprocessing to Nuclear Fuel Services for the West Valley plant, near Buffalo, NY. The plant operated from 1966 until 1972, reprocessing spent fuel from the defense weapons program. Commercial spent fuel was never reprocessed. Stricter regulatory 
requirements forced the plant's shutdown for upgrades. The plant was permanently shut down in 1976 after it was determined that the stricter regulatory requirements could not be met.

1967. The AEC authorized General Electric Company (GE) to construct a spent fuel reprocessing facility in Morris, IL.

1969. The AEC invited public comment on a proposed policy in the form of Appendix F to 10 C.F.R. Part 50 on siting a fuel reprocessing plant.

1969. EBRII fuel reprocessing and refabrication operations were suspended.

1970. Allied-General Nuclear Services began constructing a large commercial reprocessing plant at Barnwell, SC.

1972. GE halted construction and decided not to pursue an operating license for its Morris reprocessing facility. Instead, GE applied for and received a license to store spent fuel.

1974. The AEC determined that any decision to permit nuclear fuel reprocessing on a large scale would require an environmental impact statement under Section 101(2)(c) of the National Environmental Policy Act (U.S.C. 4332(2)(c)).

\section{This decision provided to help terminate Barnwell.}

1976. Exxon applied for a license to construct a large reprocessing plant but received no final action on its license application.

1977. The NRC issued an order terminating the proceedings on the Generic Environmental Statement on Mixed Oxide Fuel and most license proceedings relating to plutonium recycling. It stated, however, that it would reexamine this decision after two studies of alternative fuel cycles were completed.

1981. Convinced that the project could not proceed on a private basis and that reprocessing was commercially impracticable, Allied halted the Barnwell project.

1990. In the National Defense Authorization Act for Fiscal Year 1991 (P.L. 101-510, Sec. 3142), Congress declared under Findings and Declaration of Policy that

[a]t the present time, the United States is observing a de facto moratorium on the production of fissile materials, with no production of highly enriched uranium for nuclear weapons since 1964 . While the United States has ceased operation of all of its reactors used for the production of plutonium for nuclear weapons, the Soviet Union currently operates as many as nine reactors for the production of plutonium for nuclear weapons." Also, under Sec. 3143 - Bilateral Moratorium on Production of Plutonium and Highly Enriched Uranium for Nuclear Weapons and Disposal of Nuclear Stockpiles, the law urged "an end by both the United States and the Soviet Union to the production of plutonium and highly enriched uranium for nuclear weapons.

(In its fullest sense, plutonium production implies reprocessing.)

1992. President G. H. W. Bush disapproved Long Island Power Authority's attempt to enter into a contract with the French firm Cogema to reprocess the slightly irradiated initial core from the decommissioned Shoreham reactor.

1992. President G. H. W. Bush halted weapons reprocessing in a policy statement on nuclear nonproliferation declaring: "I have set forth today a set of principles to guide our nonproliferation efforts in the years ahead and directed a number of steps to supplement our existing efforts. These steps include a decision not to produce plutonium and highly enriched uranium for nuclear explosive purposes." 


\subsubsection{GAO, "Global Nuclear Energy Partnership - DOE Should Reassess Its Approach to Designing and Building Spent Nuclear Fuel Recycling Facilities," report GAO-08-483, April 2008.}

Note what is not in this report - there is no mention of prohibition on recycling/reprocessing. It does mention that the Nuclear Waste Policy Act prohibits use of the nuclear waste fund for reprocessing.

DOE has supported $\mathrm{R} \& \mathrm{D}$ on the advanced reprocessing and nuclear reactor technologies envisioned under GNEP for a number of years under an existing program, the Advanced Fuel Cycle Initiative. Under this program, DOE has evaluated options for managing spent nuclear fuel, including variations of recycling using different reprocessing technologies and types of reactors. DOE also conducted extensive R\&D in the 1970s, 1980s, and early 1990 s on previous concepts for advanced reprocessing and reactor technologies. These previous concepts were not implemented, in part because of concerns about their cost and technical challenges.[GAO, "Nuclear Science: Developing Technology to Reduce Radioactive Waste May Take Decades and Be Costly, GAO/RCED-94-16 (Washington, D.C.: Dec. 10, 1993).]

Similar concerns have been raised about implementing GNEP. Although Congress provided for an Advanced Fuel Cycle Initiative program in the Energy Policy Act of 2005,7 subsequent committee reports have expressed skepticism about specific aspects of DOE's efforts under GNEP-for example, whether DOE has focused on the recycling technologies best able to achieve GNEP's objectives.

Organizations concerned about nuclear energy and nuclear nonproliferation have also raised concerns about whether GNEP will achieve its objectives. Some have argued that a U.S. decision to participate in reprocessing of commercial spent nuclear fuel would encourage other countries that do not currently have reprocessing capabilities to develop them, increasing the risk of nuclear weapons proliferation rather than reducing it. Finally, DOE has a poor record of managing major design and construction projects, particularly those that use new technologies. For example, we reported in 2007 that most of DOE's major projects we reviewed had exceeded cost or schedule estimates, in part because DOE had not systematically ensured that critical technologies reflected in its project designs had been demonstrated to work as intended before committing to construction expenses for full-scale facilities. [GAO, "Department of Energy: Major Construction Projects Need a Consistent Approach for Assessing Technology Readiness to Help Avoid Cost Increases and Delays," GAO-07-336 (Washington, D.C.: Mar. 27, 2007).]

Industry has also proposed, in expressions of interest and deliverables submitted to DOE, that at least a portion of the fee that nuclear power plant operators now pay into the Nuclear Waste Fund - a special fund under DOE's jurisdiction, subject to annual appropriations by Congress, for disposal of spent fuel in a geologic repository - be used to pay for a commercial reprocessing plant. 15 Proponents of this option have called for establishing a separate government entity that could access the fund, potentially without the need for annual appropriations. They have also suggested that the current fee be increased to cover the full costs of spent fuel disposal, including the cost of both a geologic repository and a reprocessing plant. Implementing this proposal would require substantial legislative and regulatory changes. For example, the Nuclear Waste Policy Act does not allow the Nuclear Waste Fund to be used for reprocessing activities. DOE officials said that, while they recognize that current legislation limits how the Nuclear Waste Fund can be used, they would not rule out proposals to use the fund for GNEP. Instead, a decision by the Secretary of Energy to support such proposals would be contingent on a change in legislation.

\subsubsection{DOE, "Analysis of the Total System Life Cycle Cost of the Civilian Radioactive Waste Management Program, Fiscal Year 2007," report DOE/RW-0591, July 2008.}

The Analysis of the Total System Life Cycle Cost (TSLCC) of the Civilian Radioactive Waste Management Program presents the Office of Civilian Radioactive Waste Management's (OCRWM) May 2007 total system cost estimate for the disposal of the Nation's spent nuclear fuel (SNF) and high-level 
radioactive waste (HLW). The TSLCC analysis provides a basis for assessing the adequacy of the Nuclear Waste Fund (NWF) Fee as required by Section 302 of the Nuclear Waste Policy Act of 1982 (NWPA), as amended. In addition, the TSLCC analysis provides a basis for the calculation of the Government's share of disposal costs for government-owned and managed SNF and HLW. The TSLCC estimate includes both historical costs and costs projected through decommissioning of the Yucca Mountain Repository in 2133. This estimate updates the last published TSLCC, which was released in 2001. The 2001 estimate was reported in constant 2000 dollars and this estimate is in 2007 dollars. To provide comparison, summary level charts within the 2007 TSLCC are stated in both 2000 and 2007 dollars.

\subsubsection{Ken-ichi Yoshioka, Shouichi Watanabe, Ishi Mitsuhashi, Satoshi Gunji, Mitsuaki Yamaoka, Kouji Hiraiwa, A Minimal-Content Gadolinia in Above- $5 w t \%$ Enrichment Fuel for Criticality Safety in Next-Generation LWR, Advances in Nuclear Fuel Management IV (ANFM 2009), Hilton Head Island, South Carolina, USA, April 12-15, 2009.}

Proposes to go above 5\%.

In Japanese criticality safety, the regulations shift $<5 \%$ to $>5 \%$ enrichment.

\subsubsection{Dale Lancaster, Charles Rombough, Francis Alcorn, Thomas P. McLaughlin, "Critical Safety Issues Associated with Uranium Enriched Up to Ten Weight Percent," Advances in Nuclear Fuel Management IV (ANFM 2009), Hilton Head Island, South Carolina, USA, April 12-15, 2009.}

\section{Deals with criticality safety between 5 and $10 \%$ enrichment}

The arbitrary margin of subcriticality (also called the Margin of Subcriticality (MoS) or Minimum Margin of Subcriticality (MMS), which are all different names for the same thing) is an "arbitrary" value based on the licensing process and discussions between the individual licensees and their regulator. Based on the knowledge of cross sections, available benchmarks, and sensitivity studies, there is no calculational reason why the MoS value should be any different for $10 \mathrm{wt} \%$ fuel than it is for $5 \mathrm{wt} \%$ fuel.

\subsubsection{Michael F. Weber, Director, Office of Nuclear Material Safety and Safeguards, Nuclear Regulatory Commission, "Update on Reprocessing Regulatory Framework-Summary of Gap Analysis," SECY-09-0082, May 28, 2009.}

The author primarily looked at this to see if there were any previously unidentified NRC CFRs of relevance or if the NRC staff had identified any legal prohibition toward reprocessing, plutonium, etc. No such problems were found in this document.

The staff categorized each gap identified in the enclosure as one of four different types:

- Lack of regulations.

- Existing regulations pose a significant hindrance or regulatory burden to effective and efficient licensing.

- Gap resulting from potentially licensing a production facility under Part 70 (versus Part 50).

- Requirements exist, but modifications may be needed for clarity. 
Additionally, the staff assigned the gaps qualitative priorities for resolution (i.e., low, moderate, or high priority). Gaps 1-14 are characterized as "high" priority, gaps 15-19 are "moderate," and gaps 20-23 are "low" priority gaps.

High priority gaps are those that must be resolved to establish an effective and efficient regulatory framework. An example of a high priority gap is Gap 2, "Independent storage of high level waste." Gap 2 describes the lack of available independent waste storage options to accommodate solidified high level waste. The staff will pursue high priority gaps in the technical basis development.

Moderate priority gaps are those that should be resolved, but are not essential, at this stage. An example of a moderate priority gap is Gap 15, "Waste confidence for reprocessing facilities." Gap 15 details that the existing waste confidence rule does not apply to reprocessing facilities. Because applicants for reprocessing facility licenses can address long-term storage of their waste in their environmental reports, resolution of Gap 15 was not determined to be essential at this point. However, the effectiveness and efficiency of the regulatory process could be enhanced by resolving this gap through rulemaking. Moderate priority gaps will be addressed in the technical basis development, in conjunction with the high priority gaps, if sufficient resources are available.

Low priority gaps could be resolved, but are not determined to be essential. An example of a low priority gap is Gap 20, "Advanced fuel cycles and transuranic special nuclear material (SNM) classification." Gap 20 details the need to expand SNM requirements to other materials in order to accommodate reprocessing technologies. The Commission did not support this expansion, as stated in the SRM to SECY-08-0059, "Rulemaking Plan: Part 74-Material Control and Accounting of Special Nuclear Material," dated February 5, 2009, and this gap will not be pursued in the reprocessing technical basis. Staff has determined that for the reprocessing framework development, low priority gaps are not essential and will not be pursued in the technical basis development, unless the Commission directs the staff to do so.

Effluent Limits Established by the Environmental Protection Agency - The U.S. Environmental Protection Agency (EPA) regulations at 40 CFR Part 190, "Environmental Radiation Protection Standards for Nuclear Power Operations," establish dose and effluent limits for "uranium fuel cycle" operations, which includes the "reprocessing of spent uranium fuel" (40 CFR 190.02(b), 40 CFR 190.10). These EPA dose and effluent limits could pose a challenge for reprocessing facilities. However, as these limits are established by the EPA, they are not considered in the NRC regulatory gap analysis. The staff is aware of industry efforts to raise the awareness of this issue with EPA. If EPA considers revisions to 40 CFR Part 190, the NRC staff will keep the Commission informed and ensure that appropriate conforming changes to our regulations are forwarded for Commission consideration.

\section{Waste incidental to reprocessing}

Gap - The NRC lacks regulations defining certain waste streams resulting from spent fuel reprocessing as waste incidental to reprocessing, or incidental waste, rather than HLW.

Basis for Gap - The staff has long held the view that not all waste resulting from reprocessing would be considered HLW, thus allowing its disposition in facilities other than a deep geologic repository. Examples of incidental wastes are HLW tank residues, chopped and leached fuel hulls, irradiated fuel hardware, reprocessing facility equipment, personnel protection equipment, rags, etc.

Additional Information - The Department of Energy (DOE) has long consulted with NRC on DOE's nonHLW determinations for residual wastes associated with plutonium production facilities at its sites (Hanford, Savannah River Site, and Idaho National Laboratory). During the NRC's long history of consultation with DOE on such determinations, NRC developed criteria for incidental waste determinations. In fact, Congress, in 2004, passed legislation (Section 3116 of the Ronald W. Reagan National Defense Authorization Act for Fiscal Year 2005) that prescribes criteria very similar to those 
developed previously by the NRC, for DOE non-HLW determinations in the covered States of Idaho and South Carolina.

Incidental waste criteria were previously established by the NRC in the "1993 Denial of Petition for Rulemaking by the States of Washington and Oregon" in the Federal Register (58 FR 12342; March 3, 1993), by DOE in its 1999 Order 435.1, "Radioactive Waste Management," by the NRC in the 2002 West Valley Policy Statement, and by Congress in Section 3116 of the Ronald W. Reagan National Defense Authorization Act for Fiscal Year 2005 (see NUREG-1854, "NRC Staff Guidance for Activities Related to U.S. Department of Energy Waste Determinations" issued August 2007).

\section{Definition for reprocessing related terms}

Gap - There are currently no definitions of the terms "reprocessing," "recycling," and "vitrification."

Basis for Gap - Existing regulations 10 CFR Parts 20, 50, 51, 60, 63, 70 and 72 use the term "reprocessing" without a definition. Such definitions will need to be developed to describe both reprocessing and reprocessing facilities for $10 \mathrm{CFR}$ Chapter I.

Additional Information - SECY-08-0134, "Regulatory Structure for Spent Fuel Reprocessing," dated September 12, 2008 identifies the need to develop regulatory definitions, particularly for "reprocessing" and "recycling," as an issue related to the regulation of a reprocessing facility.

The NEI White Paper addresses the issue of definitions used in reprocessing of spent nuclear fuel and provides suggestions for such definitions.

In NUREG-1909, the ACNW\&M defines "recycle," "reprocessing," and other terminology used in reprocessing spent nuclear fuel.

\section{Waste classification}

Gap - The tables in 10 CFR 61.55, "Waste Classification," do not include all reprocessing-related radionuclides. As a result, some waste streams may be considered Class A but may not be generally acceptable for near surface disposal.

Basis for Gap - The waste classification tables in 10 CFR 61.55 include many radionuclides that would be associated with reprocessing waste streams. However, a few waste streams that contain radionuclides (e.g., krypton-85 separated from gaseous effluent, noble metals and some lanthanides) were not considered in the development of 10 CFR 61.55, and are not listed in either Table 1 or Table 2. As a result, some reprocessing facility wastes containing radionuclides that are not listed in Table 1 or 2 could be considered Class A, for which near-surface disposal is considered, by rule, to be generally acceptable. However, large quantities of some wastes containing radionuclides that are not included in Tables 1 and 2 may not actually be suitable for near surface disposal.

Additional Information - During licensing of the Louisiana Energy Services (LES) uranium enrichment facility in Lea County, NM, the Commission considered a contention regarding whether large quantities of depleted uranium should be considered Class A wastes, and suitable for near-surface disposal. In Order CLI-05-20 (In the Matter of Louisiana Energy Services [LES], October 19, 2005), the Commission directed staff, "outside of the LES adjudication, to consider whether the quantities of depleted uranium (DU) at issue in the waste stream from uranium enrichment facilities warrant amending section $61.55(\mathrm{a})(6)$ or the section 61.55(a) waste classification tables." In its response (SECY-08-0147, "Response to Commission Order CLI-05-20 Regarding Depleted Uranium," dated October 7, 2008), the staff recommended that the Commission approve limited rulemaking in which disposal facilities must perform a site-specific analysis to show that large quantities of DU are suitable for near-surface disposal. 
In its SRM for SECY-08-0147, the Commission approved the staff's recommended option for limited rulemaking for DU. The Commission also directed the following:

As a longer term action, in a future budget request the staff should propose the necessary resources for a comprehensive revision to risk-inform the 10 CFR Part 61 waste classification framework, with conforming changes to the regulations as needed, using updated assumptions and referencing the latest International Committee on Radiation Protection methodology. As part of this effort, staff should also identify any corollary or conforming legislative changes necessary to support this rulemaking, if any, as well as recommendations on how to proceed absent such legislation being enacted and other agencies that may be impacted by any changes. This effort should explicitly address the waste classification of depleted uranium. In addition, this effort should include the performance of a technical analysis for public comment concerning the disposal in a near surface facility of any long-lived radionuclide, including uranium. This analysis and the resulting comments should inform the staff's eventual recommendation to the Commission on an appropriate generic requirement addressing such disposals.

The ACNW\&M letter to Chairman Dale Klein of October 11, 2007, titled "Regulations of Advanced Spent Nuclear Fuel Reprocessing and Refabrication Facilities," discusses impacts of reprocessing waste on waste management and classification of LLW.

\section{Advanced fuel cycles and transuranic special nuclear material (SNM) classification}

Gap - Existing regulations do not address security risks for other fissile material that can be separated in more advanced fuel cycle separations.

Basis for Gap - Certain fissile elements such as americium (Am), neptunium (Np), and others are currently not regulated or treated as other fissile or SNM material. Such elements will be constituents in spent nuclear fuel and reprocessing facilities.

Additional Information - The policy indicated by the Commission in SRM-SECY-08-0059 does not support expanding requirements for SNM to other elements. Some advanced fuel cycle separation methods have the ability to separate actinides such as Am and others, resulting in separated and pure fissile products. However, such advanced fuel cycle separation methods are not industrially mature and are still being researched. If advanced fuel cycles that separate other fissile elements not classified as SNM become a commercial interest, the Commission may consider revisiting the policy on SNM communicated in SRMSECY-08-0059. At this stage, it is not clear that such requirements need to be incorporated into the reprocessing regulatory framework due to the immaturity of the technology for separating such actinides.

Implications for Regulating and/or Licensing Reprocessing Facilities - Currently, to truly risk-inform 10 CFR Parts 73 and 74, control of certain elements as SNM may be warranted and necessary. If such requirements were imposed for $\mathrm{Am}, \mathrm{Np}$, and perhaps other elements, broader changes may be needed throughout the regulations. Before the NRC can license a process that separates materials such as Am and $\mathrm{Np}$, the development of a measurement program (i.e., guidance, regulations and certified laboratory standards that are the basis for accrediting a measurement program) would require significant time. Other examples of possible regulatory changes could involve redefinition of strategic, moderate strategic and low strategic SNM; general licensing of certain gauges; and the classification of waste streams for processes where such material is handled as waste. Also, imposing requirements on such transuranics may have impacts on existing treaties and the international community. Additionally, if the NRC were to receive an application that proposed separation of fissile material other than SNM, the Commission would need to evaluate such applications for the potential issuance of orders to the licensee. 


\subsubsection{Matthew Bunn and Martin B. Malin, "Enabling a Nuclear Revival-And Managing Its Risks," Innovations, Fall 2009, pp. 173-191.}

Unfortunately, in many countries, the security measures in place to prevent theft of weapons-usable materials are demonstrably insufficient to defeat the kinds of threats terrorists and criminals have shown they can pose. As a result, theft and illicit trafficking of nuclear materials is not a hypothetical concern but an ongoing and current reality. The IAEA, for example, has documented 18 cases of theft or loss of plutonium or highly enriched uranium (HEU) - the essential ingredients of nuclear weapons - confirmed by the states concerned. That reality was driven home in November 2007, when two armed teams simultaneously attacked the Pelindaba nuclear facility in South Africa, which contains hundreds of kilograms of HEU. One of the groups successfully disabled the security systems and the attackers made their way to the control room, shooting a security officer there before any alarm was sounded. Although they did not seize any HEU, they escaped before external security reinforcements arrived and were never apprehended.

\subsubsection{0 "National Security Strategy," May 2010.}

Furthermore, our international order must recognize the increasing influence of individuals in today's world. There must be opportunities for civil society to thrive within nations and to forge connections among them. And there must be opportunities for individuals and the private sector to play a major role in addressing common challenges - whether supporting a nuclear fuel bank, promoting global health, fostering entrepreneurship, or exposing violations of universal rights. In the 21 st century, the ability of individuals and nongovernment actors to play a positive role in shaping the international environment represents a distinct opportunity for the United States.[Page 13]

Deny Terrorists Weapons of Mass Destruction: To prevent acts of terrorism with the world's most dangerous weapons, we are dramatically accelerating and intensifying efforts to secure all vulnerable nuclear materials by the end of 2013, and to prevent the spread of nuclear weapons. We will also take actions to safeguard knowledge and capabilities in the life and chemical sciences that could be vulnerable to misuse.[Page 20]

Strengthen the Nuclear Non-Proliferation Treaty: The basic bargain of the NPT is sound: countries with nuclear weapons will move toward disarmament; countries without nuclear weapons will forsake them; and all countries can access peaceful nuclear energy. To strengthen the NPT, we will seek more resources and authority for international inspections. We will develop a new framework for civil nuclear cooperation. As members of the Global Nuclear Energy Partnership have agreed, one important element of an enhanced framework could be cradle-to-grave nuclear fuel management. We will pursue a broad, international consensus to insist that all nations meet their obligations. And we will also pursue meaningful consequences for countries that fail to meet their obligations under the NPT or to meet the requirements for withdrawing from it.[Page 23]

Support Peaceful Nuclear Energy: As countries move increasingly to tap peaceful nuclear energy to provide power generation while advancing climate goals, the world must develop an infrastructure in the countries that seek to use nuclear energy for their energy security needs and climate goals to ensure that nuclear energy is developed in a safer manner. We will do so by promoting safety through regulatory bodies and training of operators, promoting physical security to prevent terrorist acts, and assuring safe and secure handling of fuel at the front and back ends of the nuclear fuel cycle.[Page 24]

\subsubsection{Rob P. Rechard, Tom Cotton, Hank C. Jenkins-Smith, Mark Nutt, Joe Carter, Frank Perry, Ruth F. Weiner, James A. Blink, "End of FY10 Report - Used Fuel Disposition Technical Bases and Lessons Learned - Legal}




\section{and Regulatory Framework for High-Level Waste Disposition in the United States," SAND2010-6335, September 2010.}

When NRC's original repository regulations (10 CFR 60) were developed, the NRC expected that the insitu site characterization required by the regulation would involve $\sim 1000$ feet of underground excavation and cost less than $\$ 60$ million. By the time the first three sites were recommended for characterization in 1986 , the estimated cost of characterization had increased to over $\$ 1$ billion per site and provided a major rationale for the decision to limit characterization to one site. Continued high costs for site characterization may continue to be an obstacle to characterization of multiple sites.

Experience with characterizing the WIPP and YMP sites showed that once a site is selected for detailed evaluation, the focus moves to uncertainties and the question becomes one of whether enough work has been done to resolve them. The data needs related to uncertainty become driving factors, leading to significantly increasing costs and schedules, if unconstrained, which could occur at every site that is identified for potential selection. Program scientists tend to propose a broad set of activities that could be conducted to address uncertainty. Program managers sometimes have difficulty assessing whether they need to be done without established performance requirements to guide the program.

To counteract the tendency to expand site evaluation activities beyond what is necessary for siting and licensing decisions, several approaches can be applied. First, the regulatory framework should be established in advance of the siting process. Second, selection of multiple sites in similar media may provide both the regulator and the investigating organization a better perspective because relative uncertainties can be compared rather than abstract absolute uncertainties. Third, use of performance assessment (PA) to prioritize data collection needs has proved useful both in the US and internationally, provided the regulations give clear guidance concerning performance measures and scenarios to consider.[Pages 19-20]

The development scenario that has long been used as the basis for analysis of geologic repositories in the US and that is the reference plan described in the Yucca Mountain License application involves rapid siting and construction of full-scale repository facilities, followed by ramping up to shipping and disposing of spent fuel at a rate of 3000 tons per year as rapidly as feasible after NRC approval. This scenario was initially developed at a time when spent fuel would not be reprocessed, and when it was assumed that disposal of spent fuel in the repository would be the way to meet the contractual obligation to accept spent fuel from utilities. Those assumptions are no longer widely accepted. Slower, more stepwise repository development scenarios focusing on earlier demonstration of disposal capability rather than full-scale disposal have been explored, and the final modular repository design developed for the license application could accommodate such scenarios. Developing and demonstrating the capability to dispose SNF/HLW may be a more important near-term objective rather than rapidly implementing that capability on a large scale. Hence, an adaptive staging approach for stepwise repository development appears more suited to current needs.

The charter for the Blue-Ribbon Commission on America's Nuclear Future says that it will consider "Options for decision-making processes for management and disposal that are flexible, adaptive, and responsive." The management approach called "adaptive staging" recommended in the 2003 report from the National Academies (One Step at a Time: The Staged Development of Geologic Repositories for High-Level Radioactive Waste) as "a promising means to develop geologic repositories for high-level waste such as the proposed repository at Yucca Mountain, Nevada," appears relevant to this aspect of the Commission's task. This NAS report described adaptive staging as "a learn-as-you-go process that enables project managers to continuously reevaluate and adjust the program in response to new knowledge and stakeholder input." The Organisation of Economic Co-operation and Development (OECD) Nuclear Energy Agency (NEA) reported in 2004 (Stepwise Approach to Decision Making for Long-Term Radioactive Waste Management - Experience, Issues, and Guiding Principles) that staged 
development (adaptive staging) is attracting increasing attention internationally as a means to increase the societal acceptability of waste management activities.

The current regulatory and statutory structure appears to be consistent with at least some forms of staging (e.g. constructing the repository facilities in a stepwise manner beginning with pilot scale facilities after a construction authorization for the full repository is granted). However, it would be helpful for new legislation and regulations to explicitly recognize and facilitate staged development. Furthermore, it would be helpful for new generic repository regulations to be crafted to ensure that appropriate interactions with the regulator, such as the Key Technical Issue interactions related to Yucca Mountain, can take place as an important part of a staged development process. A useful model may be in the EPA process for certifying WIPP's compliance with the performance standard via an open rulemaking process rather than a litigated adjudicatory licensing process, which was particularly conducive to open and continued external interactions by project scientists all the way through the certification process. [Page 22]

Survey research shows public attitudes toward UNF management options are sensitive to specified policy design elements. Retrievability is generally preferred, both because the public views UNF as a possible future resource and because the public prefers to retain the option to revise UNF storage strategies in light of new learning. Survey research shows that the public favors retaining the option for reprocessing UNF by a two-to-one majority.

Survey research shows that specific facility design elements can substantially alter the level of public support for storage/disposal facility siting. Public support for a UNF repository is increased substantially if it is combined with a national laboratory focused on increasing safety of UNF storage. Rather than separating storage/disposal function, combining the storage/disposal facility with reprocessing UNF also increases public support for siting the storage/disposal facility. Overall, it appears that combining a storage/disposal repository with other UNF management functions to construct a facility that seeks to examine and eventually solve many of the risk issues involved with nuclear material reduces the negative, stigmatizing imagery attached to strictly disposal facilities that, by their very function, treat these materials solely as a waste.

In $2010,40 \%$ of the respondents surveyed opposed indefinite on-site storage and $34 \%$ were undecided. The remaining $26 \%$ favored continuing the current practice. These responses indicate that, although the public is decidedly uneasy about indefinite on-site storage, there remains sufficient latitude (with a third of the public undecided) for determining an acceptable option.

Mean preferences for continued on-site storage and between six and eight regional storage/disposal facilities are statistically indistinguishable; both are preferred over two centralized storage/disposal facilities. Although strong preferences for the number of storage/disposal facilities have yet to develop, support for a larger number of sites - whether regional or continued at reactors - was greater than support for two centralized sites. This suggests that the public would not rule out multiple storage/disposal facilities, in concept.[Pages 29-30]

For this paper, the term "used fuel" or "used nuclear fuel" (UNF) is applied to fuel that has been irradiated in a reactor but for which no decision has been made about whether it will be reprocessed to recover usable materials or disposed. The public perception of UNF as a resource is discussed in $\$ 9.0$. The Nuclear Waste Policy Act of 1982 (NWPA) Pub. L. 97-425 defines spent nuclear fuel (SNF) as "fuel that has been withdrawn from a nuclear reactor following irradiation, the constituent elements of which have not been separated by reprocessing." This paper uses the term "spent fuel" or "spent nuclear fuel" (SNF) for fuel that has been designated as having no further economic value and is destined for disposal.[footnote on page 31] 


\subsubsection{World Nuclear Organization, Research Reactors, Updated March 2011, http://world-nuclear.org/info/inf61.html}

Highly-enriched uranium (HEU - >20\% U-235) allowed more compact cores, with high neutron fluxes and also longer times between refuelling. Therefore many reactors up to the late 1970 s used it, and most state-of-the-art reactors had $93 \%$ enriched fuel.

Since the early 1970 s security concerns have grown, especially since many research reactors are located at universities and other civilian locations with much lower security than military weapons establishments where much larger quantities of HEU exist. Since 1978 only one reactor, the FRM-II at Garching in Germany, has been built with HEU fuel, while more than 20 have been commissioned on LEU fuel in 16 countries. The Jules Horowitz reactor in France will start up in 2013 on uranium silicide fuel enriched to $27 \%$, since the planned high-density U-Mo fuel will not be ready in time for it.)

The question of enrichment was a major focus of the UN-sponsored International Nuclear Fuel Cycle Evaluation in 1980. It concluded that to guard against weapons proliferation from the HEU fuels then commonly used in research reactors, enrichment should be reduced to no more than $20 \% \mathrm{U}-235$. This followed a similar initiative by the USA in 1978 when its program for Reduced Enrichment for Research and Test Reactors (RERTR) was launched.

Most research reactors using HEU fuel were supplied by the USA and Russia, hence efforts to deal with the problem are largely their initiative. The RERTR program concentrates on reactors over $1 \mathrm{MW}$ which have significant fuel requirements. Overall 129 reactors out of the 207 using HEU in 2007 are targeted for conversion, and some 20 tonnes of HEU is involved. However, some are defence-related (mostly in Russia) or impractical for other reasons. Some have lifetime cores which require no refueling, so there is little incentive to convert them.

In 2004 the US National Nuclear Security Administration (NNSA) set up the Global Threat Reduction Initiative (GTRI), which is congruent with RERTR objectives though it is mainly tackling the disposition of HEU fuel (fresh and used) and other radiological materials. RERTR is now a major part of GTRI. GTRI claims accelerated removal of Russian-origin fresh and used HEU fuel to Russia and of US-origin fuel to the USA, the total involved being nearly a tonne. In particular, to January $2010,915 \mathrm{~kg}$ of fresh and used HEU fuel has been returned to Russia from at least 11 countries including Hungary $(155 \mathrm{~kg})$, Serbia, Romania, Libya, Uzbekistan, Poland, Czech Republic, Latvia and Vietnam. And to mid-January 2010, $1240 \mathrm{~kg}$ of US-origin HEU fuel has been returned from Europe, Israel, Turkey, Latin America, Japan and SE Asia.

After a hiatus of six years the US government late in 2008 had converted five university research reactors from using high- to low-enriched uranium fuel.* It was reported in 2006 that worldwide, 40 remained to be converted under the RERTR scheme using currently-available fuels, and 19 more await development of high-density fuel.

* Texas A\&M, University of Florida, Purdue, Oregon State and Washington State University reactors can now operate on fuel of less than $20 \%$ enrichment, and the University of Wisconsin reactor is to be converted in 2009.

These RERTR programs have led to the development and qualification of new, high density, low enriched uranium (LEU) fuels. The original fuel density was about $1.3-1.7 \mathrm{~g} / \mathrm{cm} 3$ uranium. Lowering the enrichment meant that the density had to be increased. Initially this was to $2.3-3.2 \mathrm{~g} / \mathrm{cm} 3$ with existing UAl fuel types.

To September 2009, 67 research reactors (17 in USA) had been converted to low-enriched uranium silicide fuel or shut down, including major reactors in Ukraine, Uzbekistan and South Africa. Another 34 
are convertible using present fuels. A further 28 , mostly Russian designs but including two US university reactors, need higher-density fuels not yet available. The goal is to convert or shut 129 reactors by 2018 . US exports of HEU declined from $700 \mathrm{~kg} / \mathrm{yr}$ in mid 1970 s to almost zero by 1993 . “

\subsubsection{Mark Holt/CRS, "Civilian Nuclear Waste Disposal," Congressional Research Service report RL33461, August 30, 2011.}

Reactor owners have no choice but to sign standard contracts with DOE for spent fuel removal. If $D O E$ can begin taking spent nuclear fuel from plant sites by 2020, DOE's estimate of its liabilities are 13 billion.

NWPA section 302 authorized DOE to enter into contracts with U.S. generators of spent nuclear fuel and other highly radioactive waste; under the contracts, DOE was to dispose of the waste in return for a fee on nuclear power generation. The act prohibited nuclear reactors from being licensed to operate without a nuclear waste disposal contract with DOE, and all reactor operators subsequently signed them. 13 As required by NWPA, the contracts specified that DOE would begin disposing of nuclear waste no later than January 31, 1998.

After DOE missed the contractual deadline, nuclear utilities began filing lawsuits to recover their additional storage costs - costs they would not have incurred had DOE begun accepting waste in 1998 as scheduled. DOE reached its first settlement with a nuclear utility, PECO Energy Company (now part of Exelon), on July 19, 2000. The agreement allowed PECO to keep up to $\$ 80$ million in nuclear waste fee revenues during the subsequent 10 years. However, other utilities sued DOE to block the settlement, contending that nuclear waste fees may be used only for the DOE waste program and not as compensation for missing the disposal deadline. The U.S. Court of Appeals for the 11th Circuit agreed, ruling September 24,2002, that any compensation would have to come from general revenues or other sources than the waste fund.

Through January 2011, the Department of Justice had negotiated 12 settlements of the 74 lawsuits filed against DOE for missing the waste disposal deadline. Under the settlements, utilities submit annual reimbursement claims to DOE for any delay-related nuclear waste storage costs they incurred during that year. Any disagreements over reimbursable claims between DOE and a utility would go to arbitration. Through January 2011, the federal government had paid about $\$ 956$ million under the settlements and for two court judgments. 14 The payments are made from the U.S. Treasury's Judgment Fund, a permanent account that is used to cover damage claims against the U.S. government. 15

Other nuclear utilities have not reached settlements, but have continued pursuing their damage claims through the U.S. Court of Federal Claims. Unlike the settlements, which cover all past and future damages resulting from DOE's nuclear waste delays, awards by the Court of Claims can cover only damages that have already been incurred; therefore, utilities must continue filing claims as they accrue additional delay-related costs. About 30 cases involving initial damage claims have been decided in the Court of Claims so far, and about 30 more are pending. 16 According to the Congressional Budget Office (CBO), the federal government's current liability for settlements, final judgments, and entered judgments under appeal stood at $\$ 1.8$ billion in July 2010.17

DOE estimated in July 2008 that its potential liabilities for waste program delays would total $\$ 11$ billion through 2056 (in current dollars) if the department were able to begin taking spent nuclear fuel from plant sites by 2020, which had been the most recent goal under the previous Administration. (That estimate has since been raised to at least $\$ 13$ billion.18) DOE's methodology for this estimate is shown in Figure 1. The yellow line shows DOE's estimate of how much spent fuel would have been removed from nuclear plant sites had shipments begun on the NWPA deadline of January 1998. The rate of waste acceptance under that scenario is 900 metric tons per year from 1998 through 2015 and 2,100 tons/year thereafter. 
That assumed acceptance rate was negotiated by DOE as part of the settlements discussed above. The annual costs reimbursed by DOE under the settlements cover utilities' expenses for storing waste that would have already been taken away under the assumed acceptance rate (the yellow line). 


\subsection{Laws and Congressional Ratifications}

This subsection describes a dozen laws. It follows, rather than precedes, section 4.1 because section 4.1 creates a detailed timeline of events via documents. The following laws, of course, were passed at specific points in time, but most were subsequently amended. Thus, one can consider either (a) the text of the law at the time it was passed or (b) the text of the law as amended, which is what has force today. Rather than further complicate this report, only the amended text is shown here. Section 4.1 is sufficient to create an understanding of the timeline.

\subsubsection{Atomic Energy Act of 1946}

Signed by President Truman on August 1, 1946. This act established the Atomic Energy Commission. It has no current legal force as it was replaced with the Atomic Energy Act of 1954, [AEA1954] which is still in force. There is no mention of U233, any of the specific isotopes of Pu, or any of the transuranic elements or isotopes.

Sec. 5(a)(1) Definition - As used in this Act, the term "fissionable material" means plutonium, uranium enriched in the isotope 235, any other material which the Commission determines to be capable of releasing substantial quantities of energy through nuclear chain reaction of the material, or any material artificially enriched by any of the foregoing; but does not include soured materials, as defined in section $5(b)(1)$.

Sec. 5(b)(1) Definition - As used in this Act, the term "source material" means uranium, thorium, or any other material which is determined by the commission, with the approval of the President, to be peculiarly essential to the production of fissionable materials; but includes ores only if they contain one or more of the foregoing materials in such concentration as the Commission may by regulation determine from time to time.

\subsubsection{Atomic Energy Act of 1954, as amended (P.L. 83-703)}

Text of this act can be found in NUREG-0980, volume 1, item 2A. It is dated August 30, 1954.

It replaced the Atomic Energy Act of 1946. Also, by explicit reference, this law incorporated into law various Executive Orders between 1945 and 1947. The Energy Reorganization Act of 1974 split AEC into ERDA and NRC.

\section{Sec. 11 Definitions}

c. The term "atomic energy" means all forms of energy released in the course of nuclear fission or nuclear transformation.

e. The term "byproduct material" means -

(1) any radioactive material (except special nuclear material) yielded in or made radioactive by exposure to the radiation incident to the process of producing or utilizing special nuclear material;

(2) the tailings or wastes produced by the extraction or concentration of uranium or thorium from any ore processed primarily for its source material content.

f. The term "Commission" means the Atomic Energy Commission.

z. The term "source material" means (1) uranium, thorium, or any other material which is determined by the Commission pursuant to the provisions of section 61 to be source material; or (2) ores containing one 
or more of the foregoing materials, in such concentration as the Commission may by regulation determine from time to time.

aa. The term "special nuclear material" means (1) plutonium, uranium enriched in the isotope 233 or in the isotope 235, and any other material which the Commission, pursuant to the provisions of section 51, determines to be special nuclear material, but does not include source material; or (2) any material artificially enriched by any of the foregoing, but does not include source material.

Thus, relative to the Atomic Energy Act of 1946, the term SNM replaces "fissionable material" and U233 is added to the list of such materials.

dd. The terms "high-level radioactive waste" and "spent nuclear fuel" have the meanings given such terms in section 2 of the Nuclear Waste Policy Act of 1982 (42 USC 10101).

\section{P.L. 100-408, 102 Stat. 1066 (1988), added subsections dd-jj.}

ee. The term "transuranic waste" means material contaminated with elements that have an atomic number greater than 92, including neptunium, plutonium, americium, and curium, and that are in concentrations greater than 10 nano-curies per gram, or in such other concentrations as the Nuclear Regulatory Commission may prescribe to protect the public health and safety.

\section{Sec. 54. Foreign Distribution of Special Nuclear Material}

(a)(i) the Commission is hereby authorized, subject to the provisions of section 123 , to distribute to the Agency, five thousand kilograms of contained uranium-235, five hundred grams of uranium-233, and three kilograms of plutonium ....

(b) Notwithstanding the provisions of sections 123,124, and 125, the Commission is authorized to distribute to any person outside the United States (1) plutonium containing 80 percent centrum or more by weight of plutonium-238, and (2) other special nuclear material when it has, in accordance with subsection 57d., exempted certain classes or quantities of such other special nuclear material or kinds of uses or users thereof from the requirements for a license set forth in this chapter. Unless hereafter otherwise authorized by law, the Commission shall be compensated for special nuclear material so distributed at not less than the Commission's published charges applicable to the domestic distribution of such material. The Commission shall not distribute any plutonium containing 80 per centrum or more by weight of plutonium-238 to any person under this subsection if, in its opinion, such distribution would be inimical to the common defense and security. The Commission may require such reports regarding the use of material distributed pursuant to the provisions of this subsection as it deems necessary.

The above section 54 was amended in 1974; the earlier text did not have the $80 \%$ Pu238 clauses.

\section{Sec. 123. Cooperation With Other Nations}

No cooperation with any nation, group of nations or regional defense organization pursuant to section 53, $54 \mathrm{a}, 57,64,82,91,103,104$, or 144 shall be undertaken until-

a. The proposed agreement for cooperation has been submitted to the President, which proposed agreement shall include the terms, conditions, duration, nature, and scope of the cooperation; and shall include the following requirements:

Various clauses follow, but the point is that international material transfers defer to the President.

\section{Sec. 131. Subsequent Arrangements}

a.(1) Prior to entering into any proposed subsequent arrangement under an agreement for cooperation (other than an agreement for cooperation arranged pursuant to section 91c, 114b., or 114c. of this Act), 
the Secretary of Energy shall obtain the concurrence of the Secretary of State and shall consult with the Commission, and the Secretary of Defense: Provided, That the Secretary of State shall have the leading role in any negotiations of a policy nature pertaining to any proposed subsequent arrangement regarding arrangements for the storage or disposition of irradiated fuel elements or approvals for the transfer, for which prior approval is required under an agreement for cooperation, by a recipient of source of special nuclear material, production or utilization facilities, or nuclear technology.

\section{Sec. 134. Further Restrictions on Exports}

HEU is defined as U-235 over $20 \%$ in the context of medical isotope production.

Later, in the context of test reactors or reactors producing medical isotopes, HEU is again defined as $20 \%$ or more $U-235$.

The text appears to establish the policy to avoid exports of HEU for such purposes and only when it is infeasible to use LEU should HEU be used. Most of that text appears to be far newer than the original 1954 text - mostly the Energy Policy Act of 2005.[EnergyPolicyAct2005]

\section{Sec. 159. Federally Financed Research}

Nothing in this Act shall affect the right of the Commission to require the patents granted on inventions made or conceived during the source of federally financed research or operations, be assigned to the United States.

\section{Sec. 193. Licensing of Uranium Enrichment Facilities}

(a)(1) Major Federal Action. - The issuance of a license under sections 53 and 63 for the construction and operation of any uranium enrichment facility shall be considered a major Federal action significantly affecting the quality of the human environment for purposes of the National Environmental Policy Act of 1969 (42 USC 4321 et seq.).

\section{Sec. 276. State Authority to Regulate Radiation Below Level of Regulatory Concern of Nuclear Regulatory Commission}

(a) IN GENERAL.-No provision of this Act, or of the Low-Level Radioactive Waste Policy Act, may be construed to prohibit or otherwise restrict the authority of any State to regulate, on the basis of radiological hazard, the disposal or off-site incineration of low-level radioactive waste, if the Nuclear Regulatory Commission, after the date of the enactment of the Energy Policy Act of 1992 exempts such waste from regulation.

\subsubsection{International Atomic Energy Agency Participation Act of 1957 (P.L. 85- 177)}

Text of this act can be found in NUREG-0980, volume 3, item J. The act is dated August 28, 1957.

\section{Sec. 2. Representatives}

(a) The President, by and with the advice and consent of the Senate, shall appoint a representative and a deputy representative of the United States to the International Atomic Energy Agency (hereinafter referred to as the "Agency"), who shall hold office at the pleasure of the President. Such representative and deputy representative shall represent the United States on the Board of Governors of the Agency, may represent the United States at the General Conference, and may serve exofficio as United States representative on any organ of that Agency, and shall perform such other functions in connection with the participation of the United States in the Agency as the President may from time to time direct. 
(b) The President, by and with the advice and consent of the Senate, may appoint or designate from time to time to attend a specified session or specified sessions of the General Conference of the Agency a representative of the United States and such number of alternates as he may determine consistent with the rules of procedure of the General Conference.

\subsubsection{Energy Reorganization Act of 1974, as amended (P.L. 93-438)}

Text of this act can be found in NUREG-0980, volume 1, item 3A. It is dated October 11, 1974.

This split the AEC into the Energy Research and Development Administration (ERDA) and Nuclear Regulatory Commission (NRC).

\section{Sec 201. Establishment and Transfers}

(a)(1) There is established an independent regulatory commission to be known as the Nuclear Regulatory Commission which shall be composed of five members, each of whom shall be a citizen of the United States. The President shall designated one member of the commission as Chairman thereof to serve as such during the pleasure of the President. The Chairman may from time to time designate any other member of the Commission as Acting Chairman to act in the place and stead of the Chairman during his absence.

(b)(1) Members of the Commission shall be appointed by the President, by and with the advice and consent of the Senate.

(2) Appointments of members pursuant to this subsection shall be made in such a manner that not more than three members of the Commission shall be members of the same political party.

(e) Any member of the Commission may be removed by the President for inefficiency, neglect of duty, or malfeasance in office. No member of the Commission shall engage in any business, vocation, or employment other than that of serving as member of the Commission.

\subsubsection{Department of Energy Organization Act of 1977 (P.L. 95-91)}

This act, August 4, 1977, created the Department of Energy. It transferred the administration of the functions of the Energy Research and Development Administration to DOE.

\subsubsection{The Nuclear Non-Proliferation Act of 1978 (P.L. 95-242)}

Text of this act can be found in NUREG-0980, volume 3, item A. It is dated March 10, 1978.

As a check that the author of this report has missed some key pre-1978 law, note that this law references the Atomic Energy Act of 1954, [AEA1954] The Energy Reorganization Act of 1974, and the Treaty on the Non-Proliferation of Nuclear Weapons. Each of these is discussed elsewhere in this report.

This act made several changes to the Atomic Energy Act of 1954,[AEA1954] essentially bringing the U.S. into compliance with the Non-Proliferation Treaty.

\section{Sec. 403. Peaceful Nuclear Activities}

The President shall take immediate and vigorous steps to seek agreement from all nations and groups of nations to commit themselves to adhere to the following export policies with respect to their peaceful nuclear activities and their participation in international nuclear trade:

(a) No nuclear materials and equipment and no sensitive nuclear technology within the territory of any nation or group of nations, under its jurisdiction, or under its control anywhere will be transferred to the 
jurisdiction of any other nation or group of nations unless the nation or group of nations receiving such transfer commits itself to strict undertakings including, but not limited to, provisions sufficient to ensure that-

(1) no nuclear materials and equipment and no nuclear technology in, under the jurisdiction of, or under the control of any non-nuclearweapon state, shall be used for nuclear explosive devices for any purpose or for research on or development of nuclear explosive devices for any purpose, except as permitted by Article V, the Treaty;

(2) IAEA safeguards will be applied to all peaceful nuclear activities in, under the jurisdiction of, or under control of any nonnuclear-weapon state;

(3) adequate physical security measures will be established and maintained by any nation or group of nations on all of its nuclear activities;

(4) no nuclear materials and equipment and no nuclear technology intended for peaceful purposes in, under the jurisdiction of, or under the control of any nation or group of nations shall be transferred to the jurisdiction of any other nation or group of nations which does not agree to stringent undertakings meeting the objectives of this section; and

(5) no nation or group of nations will assist, encourage, or induce any non-nuclear-weapon state to manufacture or otherwise acquire any nuclear explosive device.

(b) (1) No source or special nuclear material within the territory of any nation or group of nations, under its jurisdiction, or under its control anywhere will be enriched (as described in paragraph AA.(2) of section 11 of the 1954 Act) or reprocessed, no irradiated fuel elements containing such material which are to be removed from a reactor will be altered in form or content, and no fabrication or stockpiling involving plutonium, uranium 233, or uranium enriched to greater than 20 percent in the isotope 235 shall be performed except in a facility under effective international auspices and inspection, and any such irradiated fuel elements shall be transferred to such a facility as soon as practicable after removal from a reactor consistent with safety requirements. Such facilities shall be limited in number to the greatest extent feasible and shall be carefully sited and managed so as to minimize the proliferation and environmental risks associated with such facilities. In addition, there shall be conditions to limit the access of non-nuclear-weapon states other than the host country to sensitive nuclear technology associated with such facilities.

(2) Any facilities within the territory of any nation or group of nations, under its jurisdiction, or under its control anywhere for the necessary short-term storage of fuel elements containing plutonium, uranium 233, or uranium enriched to greater than 20 percent in the isotope 235 prior to placement in a reactor or of irradiated fuel elements prior to transfer as required in subparagraph (1) shall be placed under effective international auspices and inspection.

(c) Adequate physical security measures will be established and maintained with respect to all nuclear activities within the territory of each nation and group of nations, under its jurisdiction, or under its control anywhere, and with respect to any international shipment of significant quantities of source or special nuclear material or irradiated source or special nuclear material, which shall also be conducted under international safeguards.

(d) Nothing in this section shall be interpreted to require international control or supervision of any United States military activities. 


\subsubsection{U.S. Senate Resolution Consenting to the Ratification of the Agreement Between the U.S. and the IAEA for the Application of Safeguards (July 2, 1980.)}

Text of this ratification can be found in NUREG-0980, volume 3, item M. The act is dated July 2, 1980. Apparently, the agreement was viewed legally as a treaty; hence 2/3 vote of the Senate served to ratify it. This Senate action ratified the agreement that the U.S. signed in 1977, allowing it to go into effect later in 1980.

Resolved, (two-thirds of the Senators present concurring therein), That the Senate advised and consent to the ratification of the Agreement between the United States of America and the International Atomic Energy Agency for the Application of the Safeguards in the United States of America, with attached Protocol, signed at Vienna on November 18, 1977 (Ex. B, Ninety-fifth Congress, second session, hereinafter referred to as "the Agreement"), subject to the following understandings:

The text of the agreement ratified by the Senate can be in NUREG-0980, volume 3, item L. It was signed in Vienna on November 18, 1977.

\section{AGREEMENT BETWEEN THE UNITED STATES OF AMERICA AND THE INTERNATIONAL ATOMIC ENERGY AGENCY FOR THE APPLICATION OF SAFEGUARDS IN THE UNITED STATES OF AMERICA}

WHEREAS the United States of America (hereinafter referred to as "the United States") and the International Atomic Energy Agency (hereinafter referred to as the "Agency") are parties to an Agreement for the Application of Safeguards in the United States of America done at Vienna on November 18, 1977 (hereinafter referred to as the "Safeguards Agreement"), which entered into force on December 9, 1980;

\section{ARTICLE 36}

At the request of the United States, the Agency shall exempt from the safeguards nuclear material, which would otherwise be subject to safeguards under this Agreement, as follows:

(a) Special fissionable material, when it is used in gram quantities or less as a sensing component in instruments;

(b) Nuclear material, when it is used in non-nuclear activities in accordance with Article 13, if such

nuclear material is recoverable; and

(c) Plutonium with an isotopic concentration of plutonium-238 exceeding $80 \%$.

\section{ARTICLE 37}

At the request of the United States, the Agency shall exempt from safeguards nuclear material that would otherwise be subject to safeguards under this Agreement, provided that the total quantity of nuclear material which has been exempt in the United States in accordance with this Article may not at any time exceed:

(a) One kilogram in total of special fissionable material, which may consist of one or more of the following:

(i) Plutonium;

(ii) Uranium with an enrichment of $0.2(20 \%)$ and above, taken account of by multiplying its weight by its enrichment; and 
(iii) Uranium with an enrichment below $0.2(20 \%)$ and above that of natural uranium, taken account of by multiplying its weight by five times the square of its enrichment;

(b) Ten metric tons in total of natural uranium and depleted uranium with an enrichment above 0.005 $(0.5 \%)$;

(c) Twenty metric tons of depleted uranium with and enrichment of $0.005(0.5 \%)$ or below; and

(d) Twenty metric tons of thorium;

or such greater amounts as may be specified by the Board for uniform application.

\subsubsection{Convention on the Physical Protection of Nuclear Material Implementation Act of 1982 (P.L. 97-351)}

The text of this law can be found in NUREG-0980, volume 3, item C. It is dated October 18, 1982. It implements the international convention on physical protection of nuclear material.

\subsubsection{Nuclear Waste Policy Act of 1982, as amended (97-425)}

The text of this law can be found in NUREG-0980, volume 1, item 6A. It is dated January 7, 1983. Section 302 details what the nuclear waste fund can be used for, all other uses are forbidden. GAO-08-483 states that this law forbids use of the nuclear waste fund for reprocessing.

Sec. 2. Definitions.

(12) The term "high-level radioactive waste" means-

(A) the highly radioactive material resulting from the reprocessing of spent nuclear fuel, including liquid waste produced directly in reprocessing and any solid material derived from such liquid waste that contains fission products in sufficient concentrations; and

(B) other highly radioactive material that the Commission, consistent with existing law, determines by rule requires permanent isolation.

(16) The term "low-level radioactive waste" means radioactive material that-

(A) is not high-level radioactive waste, spent fuel, transuranic waste, or by-product material as defined in section 11e(2) of the Atomic Energy Act of 1954 (42 USC 2014(e)(2))' and

(B) the Commission, consistent with existing law, classifies as low level radioactive waste.

(23) The term "spent nuclear fuel" means fuel that has been withdrawn from a nuclear reactor following irradiation, the constituent elements of which have not been separated by reprocessing.

\section{Sec. 112. Recommendation of Candidate Sites for Site Characterization}

The DOE Secretary is mandated to issue general guidelines for the recommendation of sites for repositories.

The DOE Secretary must nominate at least 5 candidate sites.

\section{Sec. 113. Site Characterization}

(c)(3) If the Secretary at any time determines the Yucca Mountain site to be unsuitable for development as a repository, the Secretary shall - 
(F) report to Congress not later than 6 months after such determination the Secretary's recommendations for further action to assure the safe, permanent disposal of spent nuclear fuel and high-level radioactive waste, including the need for new legislative authority.

\section{Sec. 114. Site Approval and Construction Authorization}

(d) Commission Action - The Commission shall consider an application for a construction authorization for all or part of a repository in accordance with the laws applicable to such applications, except that the Commission shall issue a final decision approving or disapproving the issuance of a construction authorization not later that the expiration of 3 years after the date of the submission of such application, except that the Commission may extend such deadlines by not more than 12 months if, not less than 30 days before such deadlines, the Commission complies with the reporting requirements established in subsection (e)(2). The Commission decision approving the first such application shall prohibit the emplacement in the first repository of a quantity of spent fuel containing in excess of 70,000 metric tons of heavy metal or a quantity of solidified high-level radioactive waste resulting from the reprocessing of such a quantity of spent fuel until such time as a second repository is in operation. In the event that a monitored retrievable storage facility, approved pursuant to subtitle $\mathrm{C}$ of this Act, shall be located, or is planned to be located, within 50 miles of the first repository, then the Commission decision approving the first such application shall prohibit the employment of a quality of spent fuel containing in excess of 70,000 metric tons of heavy metal or a quantity of solidified high-level radioactive waste resulting from the reprocessing of spent fuel in both the repository and monitored retrievable storage facility until such time as a second repository is in operation.

\section{Sec. 121. Certain Standards And Criteria}

\section{(a) ENVIRONMENTAL PROTECTION AGENCY STANDARDS-}

Not later than 1 year after the date of the enactment of this Act, the Administrator, pursuant to authority under other provisions of law, shall, by rule, promulgate generally applicable standards for protection of the general environment from offsite releases from radioactive material in repositories.

\section{(b) Commission Requirements And Criteria-}

(A) Not later than January 1, 1984, the Commission, pursuant to authority under other provisions of law, shall, by rule promulgate technical requirements and criteria that it will apply, under the Atomic Energy Act of 1954 (42 USC 2011 et seq.) and the Energy Reorganization Act of 1974 (42 USC 5801 et seq.), in approving or disapproving.-

(i) applications for authorization to construct repositories;

(ii) applications for licenses to receive and possess spent nuclear fuel and high-

level radioactive waste in such repositories; and

(iii) applications for authorization for closure and decommissioning of such repositories.

(B) Such criteria shall provide for the use of a system of multiple barriers in the design of the repository and shall include such restrictions on the retrievability of the solidified

high-level radioactive waste and spent fuel emplaced in the repository as the Commission deems appropriate.

(C) Such requirements and criteria shall not be inconsistent with any comparable standards promulgated by the Administrator under subsection (a).

(2) For purposes of this Act, nothing in this section shall be constructed to prohibit the Commission from promulgating requirements and criteria under paragraph (1) before the Administrator promulgates standards under subsection (a). If the Administrator promulgates standards under subsection (a) after requirements and criteria are promulgated by the Commission under paragraph (1), such requirements and criteria shall be revised by the Commission if necessary to comply with paragraph (1) (C). 
(c) Environmental Impact Statements-The promulgation of standards or criteria in accordance with the provisions of this section shall not require the preparation of an environmental impact statement under section 102(2)(C) of the National Environmental Policy Act of 1969 (42 USC 4332(2)(C)), or to require any environmental review under subparagraph $(\mathrm{E})$ or $(\mathrm{F})$ of section $102(2)$ of such Act.

Note that 121.b.1.B states that the NRC "shall include such restrictions on the retrievability of the solidified high-level radioactive waste and spent fuel emplaced in the repository as the Commission deems appropriate."

\section{Sec. 122. Disposal of Spent Nuclear Fuel}

Notwithstanding any other provision of this subtitle, any repository constructed on a site approved under this subtitle shall be designed and constructed to permit the retrieval of any spent nuclear fuel placed in such repository, during an appropriate period of operation of the facility, for any reason pertaining to the public health and safety, or the environment, or for the purpose of permitting the recovery of the economically valuable contents of such spent fuel. The Secretary shall specify the appropriate period of retrievability with respect to any repository at the time of design of such repository, and such aspect of such repository shall be subject to approval or disapproval by the Commission as part of the construction authorization process under subsections(b) through (d) of section 114.

The DOE Secretary is given the power to specify the appropriate period of retrievability. Retrievability is only mandated for spent nuclear fuel and only during operation of the facility (i.e., before repository closure.)

\section{Sec. 136. Interim Storage Fund}

(1) During the period following the date of the enactment of this Act, but not later than January 1,1990, the Secretary is authorized to enter into contracts with persons who generate or own spent nuclear fuel resulting from civilian nuclear activities for the storage of such spent nuclear fuel in any storage capacity provided under this subtitle: Provided, however, That the Secretary shall not enter into contracts for spent nuclear fuel in amounts in excess of the available storage capacity specified in section 135(a). Those contracts shall provide that the Federal Government will (1) take title at the civilian nuclear power reactor site, to such amounts of spent nuclear fuel from the civilian nuclear power reactor as the Commission determines cannot be stored onsite, (2) transport the spent nuclear fuel to a federally owned and operated interim away-from-reactor storage facility, and (3) store such fuel in the facility pending further processing, storage, or disposal. Each such contract shall (A) provide for payment to the Secretary of fees determined in accordance with the provisions of this section; and (B) specify the amount of storage capacity to be provided for the person involved.

\section{Sec. 160. Selection of Yucca Mountain Site}

This section selected Yucca Mountain.

\section{Sec. 161. Siting a Second Repository}

(a) CONGRESSIONAL ACTION REQUIRED-The Secretary may not conduct site-specific activities with respect to a second repository unless Congress has specifically authorized and appropriated funds for such activities.

(b) REPORT-The Secretary shall report to the President and to Congress on or after January 1, 2007, but not later than January 1, 2010, on the need for a second repository.

(c) TERMINATION OF GRANITE RESEARCH-Not later than 6 months after the date of the enactment of the Nuclear Waste Policy Amendments Act of 1987, the Secretary shall phase out in an orderly manner 
funding for all research programs in existence on such date of enactment designed to evaluate the suitability of crystalline rock as a potential repository host medium.

(d) ADDITIONAL SITING CRITERIA-In the event that the Secretary at any time after such date of enactment considers any sites in crystalline rock for characterization or selection as a repository, the Secretary shall consider (as a supplement to the siting guidelines under section 112) such potentially disqualifying factors as-

(1) seasonal increases in population;

(2) proximity to public drinking water supplies, including those of metropolitan areas; and

(3) the impact that characterization or siting decisions would have on lands owned or placed in trust by the United States for Indian tribes.13

\section{Title II-Research, Development, and Demonstration Regarding Disposal of High-Level Radioactive} Waste and Spent Nuclear Fuel.

\section{Sec. 211. Purpose}

It is the purpose of this title-

(1) to provide direction to the Secretary with respect to the disposal of high-level radioactive waste and spent nuclear fuel;

(2) to authorize the Secretary, pursuant to this title-

(A) to provide for the construction, operation, and maintenance of a deep geologic test and evaluation facility; and

(B) to provide for a focused and integrated high-level radioactive waste and spent nuclear fuel research and development program, including the development of a test and evaluation facility to carry out research and provide an integrated demonstration of the technology for deep geologic disposal of highlevel radioactive waste, and the development of the facilities to demonstrate dry storage of spent nuclear fuel

\section{Sec. 213. Identification of Sites}

(a) GUIDELINES - Not later than 6 months after the date of the enactment of this Act and notwithstanding the failure of other agencies to promulgate standards pursuant to applicable law, the Secretary, in consultation with the Commission, the Director of the United States Geological Survey, the Administrator, the Council on Environmental Quality, and such other Federal agencies as the Secretary considers appropriate, is authorized to issue, pursuant to section 553 of title 5, United States Code, general guidelines for the selection of a site for a test and evaluation facility. Under such guidelines the Secretary shall specify factors that qualify or disqualify a site for development as a test and evaluation facility, including factors pertaining to the location of valuable natural resources, hydrogeophysics, seismic activity, and atomic energy defense activities, proximity to water supplies, proximity to populations, the effect upon the rights of users of water, and proximity to components of the National Park System, the National Wildlife Refuge System, the National Wild and Scenic Rivers System, the National Wilderness Preservation System, or National Forest Lands. Such guidelines shall require the Secretary to consider the various geologic media in which the site for a test and evaluation facility may be located and, to the extent practicable, to identify sites in different geologic media. The Secretary shall use guidelines established under this subsection in considering and selecting sites under this title. 
(b) SITE IDENTIFICATION BY THE SECRETARY-(1) Not later than 1 year after the date of the enactment of this Act, and following promulgation of guidelines under subsection (a), the Secretary is authorized to identify 3 or more sites, at least 2 of which shall be in different geologic media in the continental United States, and at least 1 of which shall be in media other than salt. Subject to Commission requirements, the Secretary shall give preference to sites for the test and evaluation facility in media possessing geochemical characteristics that retard aqueous transport of radionuclides in order to provide a greater possible protection of public health and safety as operating experience is gained at the test and operation facility, and with the exception of the primary areas under review by the Secretary on the date of the enactment of this Act for the location of a test and evaluation facility or repository, all sites identified under this subsection shall be more than 15 statute miles from towns having a population of greater than 1000 persons as determined by the most recent census unless such sites contain high-level radioactive waste prior to identification under this title. Each identification of a site shall be supported by an environmental assessment, which shall include a detailed statement of the basis for such identification and of the probable impacts of the siting research activities planned for such site, and a discussible impact of the siting research activities planned for such site, and a discussion of alternative activities relating to siting research that may be undertaken to avoid such impacts.

\section{Sec. 302. Nuclear Waste Fund}

(a) CONTRACTS-(1) In the performance of his functions under this Act, the Secretary is authorized to enter into contracts with any person who generates or holds title to high-level radioactive waste, or spent nuclear fuel, of domestic origin for the acceptance of title, subsequent transportation, and disposal of such waste or spent fuel. Such contracts shall provide for payment to the Secretary of fees pursuant to paragraphs (2) and (3) sufficient to offset expenditures in subsection (d).

(2) For electricity generated by a civilian nuclear power reactor and sold on or after the date 90 days after the date of enactment of this Act, the fee under paragraph (1) shall be equal to 1.0 mil per kilowatt-hour.

(3) For spent nuclear fuel, or solidified high-level radioactive waste derived from spent nuclear fuel, which fuel was used to generate electricity in a civilian nuclear power reactor prior to the application of the fee under paragraph (2) to such reactor, the Secretary shall, not later than 90 days after the date of enactment of this Act, establish a 1 time fee per kilogram of heavy metal in spent nuclear fuel, or in solidified high-level radioactive waste. Such fee shall be in amount equivalent to an average charge of 1.0 mil per kilowatt-hour for electricity generated by such spent nuclear fuel, or such solidified high-level waste derived therefrom, to be collected from any person delivering such spent nuclear fuel or high-level waste, pursuant to section 123, to the Federal Government. Such fee shall be paid to the Treasury of the United States and shall be deposited in the separate fund established by subsection (c)126(b). In paying such a fee, the person delivering spent fuel, or solidified high-level radioactive wastes derived therefrom, to the Federal Government shall have no further financial obligation to the Federal Government for the long-term storage and permanent disposal of such spent fuel, or the solidified high-level radioactive waste derived therefrom.

(4) Not later than 180 days after the date of enactment of this Act, the Secretary shall establish procedures for the collection and payment of the fees established by paragraph (2) and paragraph (3). The Secretary shall annually review the amount of the fees established by paragraphs (2) and (3) above to evaluate whether collection of the fee will provide sufficient revenues to offset the costs as defined in subsection (d) herein. In the event the Secretary determines that either insufficient or excess revenues are being collected, in order to recover the costs incurred by the Federal Government that are specified in subsection (d), the Secretary shall propose an adjustment to the fee to insure full cost recovery. The Secretary shall immediately transmit this proposal for such an adjustment to Congress. The adjusted fee proposed by the Secretary shall be effective after a period of 90 days of continuous session have elapsed following the receipt of such transmittal unless during such 90-day period either House of Congress 
adopts a resolution disapproving the Secretary's proposed adjustment in accordance with the procedures set forth for congressional review of an energy action under section 551 of the Energy Policy and Conservation Act.

\subsubsection{Energy Policy Act of 1992 (P.L. 102-486)}

NUREG-0980, volume 1, item $6 B$ has "pertinent provisions of the Energy Policy Act of 1992 (Environmental Protection Standards)" It was signed into law on October 24, 1992.

This is the law that required a study by the National Academy of Sciences on "reasonable standards for protection of the public health and safety" for disposal at the Yucca Mountain site. The EPA Administrator then sets the standards for Yucca Mountain - the Administrator shall, based upon and consistent with the findings and recommendations of the National Academy of Sciences, promulgate, by rule, public health and safety standards for protection of the public from releases from radioactive materials stored or disposed of in the repository at the Yucca Mountain site. Such standards shall prescribe the maximum annual effective dose equivalent to individual members of the public from releases to the accessible environment from radioactive materials stored or disposed of in the repository.

The resulting standards are explicitly only applicable to the Yucca Mountain site.

\subsubsection{Energy Policy Act of 2005 (P.L. 109-58)}

NUREG-0980 volume 1, item 6C has "pertinent provisions of the Energy Policy Act of 2005 - (Greaterthan-Class-C Waste)". Bush signed it into law on August 8, 2005.

\section{Sec. 631. Safe Disposal of Greater-Than-Class C Radioactive Waste}

(a) RESPONSIBILITY FOR ACTIVITIES TO PROVIDE STORAGE FACILITY.-The Secretary shall provide to Congress official notification of the final designation of an entity within the Department to have the responsibility of completing activities needed to provide a facility for safely disposing of all greater-than-Class $\mathrm{C}$ low-level radioactive waste.

\subsubsection{United States Additional Protocol Implementation Act (P.L. 109-401)}

The text can be found in NUREG-0980 volume 3, item O. It is dated December 18, 2006. This law authorizes the U.S. adoption of the IAEA Additional Protocol. Given the text below, it appears that that protocol was signed June 12, 1998, with additional clarifications worked out with the IAEA in 2002.

\section{Sec. 202. Findings.}

(6) On June 12, 1998, the United States, as a nuclear-weapon State Party, signed an Additional Protocol that is based on the Model Additional Protocol, but which also contains measures, consistent with its existing safeguards agreements with its members, that protect the right of the United States to exclude the application of IAEA safeguards to locations and activities with direct national security significance or to locations or information associated with such activities.

(7) Implementation of the Additional Protocol in the United States in a manner consistent with United States obligations under the Nuclear Non-Proliferation Treaty may encourage other parties to the Nuclear Non-Proliferation Treaty, especially non- nuclear-weapon State Parties, to conclude Additional Protocols and thereby strengthen the Nuclear Non-Proliferation Treaty safeguards system and help reduce the threat of nuclear proliferation, which is of direct and substantial benefit to the United States.

(8) Implementation of the Additional Protocol by the United States is not required and is completely voluntary given its status as a nuclear-weapon State Party, but the United States has acceded to the 
Additional Protocol to demonstrate its commitment to the nuclear nonproliferation regime and to make United States civil nuclear activities available to the same IAEA inspections as are applied in the case of non-nuclear- weapon State Parties.

(9) In accordance with the national security exclusion contained in Article 1.b of its Additional Protocol, the United States will not allow any inspection activities, nor make any declaration of any information with respect to, locations, information, and activities of direct national security significance to the United States.

(10) Implementation of the Additional Protocol will conform to the principles set forth in the letter of April 30, 2002, from the United States Permanent Representative to the International Atomic Energy Agency and the Vienna Office of the United Nations to the Director General of the International Atomic Energy Agency.

\section{Sec. 211. Authority.}

(a) In General.--The President is authorized to implement and carry out the provisions of this title and the Additional Protocol and shall designate through Executive order which executive agency or agencies of the United States, which may include but are not limited to the Department of State, the Department of Defense, the Department of Justice, the Department of Commerce, the Department of Energy, and the Nuclear Regulatory Commission, shall issue or amend and enforce regulations in order to implement this title and the provisions of the Additional Protocol.

(b) Included Authority.--For any executive agency designated under subsection (a) that does not currently possess the authority to conduct site vulnerability assessments and related activities, the authority provided in subsection (a) includes such authority.

(c) Exception.--The authority described in subsection (b) does not supersede or otherwise modify any existing authority of any Federal department or agency already having such authority.

The text of this Additional protocol can be in NUREG-0980, volume 3, item N. This seems to have signed June 12, 1998, but it was not authorized by U.S. law until 2006.

\section{PROTOCOL ADDITIONAL TO THE AGREEMENT BETWEEN THE UNITED STATES OF AMERICA AND THE INTERNATIONAL ATOMIC ENERGY AGENCY FOR THE APPLICATION OF SAFEGUARDS IN THE UNITED STATES OF AMERICA}

WHEREAS the United States of America (hereinafter referred to as "the United States") and the International Atomic Energy Agency (hereinafter referred to as the "Agency") are parties to an Agreement for the Application of Safeguards in the United States of America done at Vienna on November 18, 1977 (hereinafter referred to as the "Safeguards Agreement"), which entered into force on December 9, 1980;

\section{This first clause references the earlier US-IAEA safeguard agreement}

AWARE OF the desire of the international community to further enhance nuclear nonproliferation by strengthening the effectiveness and improving the efficiency of the Agency's safeguards system;

RECALLING that the Agency must take into account in the implementation of safeguards the need to: avoid hampering the economic and technological development of the United States or international cooperation in the field of peaceful nuclear activities; respect health, safety, physical protection and other security provisions in force and the rights of individuals; and take every precaution to protect commercial, technological and industrial secrets as well as other confidential information coming to its knowledge; 
WHEREAS the frequency and intensity of activities described in this Protocol shall be kept to the minimum consistent with the objective of strengthening the effectiveness and improving the efficiency of Agency safeguards;

\section{Article 2 - PROVISION OF INFORMATION}

a. The United States shall provide the Agency with a declaration containing.

(i) A general description of and information specifying the location of nuclear fuel cycle-related research and development activities not involving nuclear material carried out anywhere that are funded, specifically authorized or controlled by, or carried out on behalf of, the United States.

This is what required some of us in the FCR\&D program to provide information on experiments, models, etc. 


\subsection{Title 10, Code of Federal Regulations, Chapter I, Nuclear Regulatory Commission}

The full list of all 10CFRs is as follows. Those reviewed for this report are in bold.

Part

Part 1

Part 2

Part 4

Part 5

Part 7

Part 8

Part 9

Part 10

Part 11

Part 12

Part 13

Part 14

Part 15

Part 16

Part 19

Part 20

Part 21

Part 25

Part 26

Part 30

Part 31

Part 32

Part 33

Part 34

Part 35

Part 36

Part 39

Part 40

Part 50

Part 51

Part 52

Part 53

Part 54

Part 55

Part 60

Part 61

Part 62
Title

Statement of organization and general information

Rules of practice for domestic licensing proceedings and issuance of orders

Nondiscrimination in Federally assisted programs or activities receiving Federal financial assistance from the Commission

Nondiscrimination on the basis of sex in education programs or activities receiving Federal

financial assistance

Advisory committees

Interpretations

Public records

Criteria and procedures for determining eligibility for access to restricted data or national security information or an employment clearance

Criteria and procedures for determining eligibility for access to or control over special nuclear material

Implementation of the Equal Access to Justice Act in agency proceedings

Program fraud civil remedies

Administrative claims under Federal Tort Claims Act

Debt collection procedures

Salary offset procedures for collecting debts owed by Federal employees to the Federal government

Notices, instructions and reports to workers: inspection and investigations

Standards for protection against radiation

Reporting of defects and noncompliance

Access authorization

Fitness for duty programs

Rules of general applicability to domestic licensing of byproduct material

General domestic licenses for byproduct material

Specific domestic licenses to manufacture or transfer certain items containing byproduct material

Specific domestic licenses of broad scope for byproduct material

Licenses for industrial radiography and radiation safety requirements for industrial radiographic operations

Medical use of byproduct material

Licenses and radiation safety requirements for irradiators

Licenses and radiation safety requirements for well logging

Domestic licensing of source material

Domestic licensing of production and utilization facilities

Environmental protection regulations for domestic licensing and related regulatory functions

\section{Licenses, certifications, and approvals for nuclear power plants}

[Reserved]

Requirements for renewal of operating licenses for nuclear power plants

Operator's licenses

Disposal of high-level radioactive wastes in geologic repositories

Licensing requirements for land disposal of radioactive waste

Criteria and procedures for emergency access to non-federal and regional low-level waste disposal facilities 


\section{Part 63 Disposal of high-level radioactive wastes in a geologic repository at Yucca Mountain, Nevada \\ Part 70 Domestic licensing of special nuclear material \\ Part 71 Packaging and transportation of radioactive material \\ Part 72 Licensing requirements for the independent storage of spent nuclear fuel and high-level radioactive waste, and reactor-related greater than Class $C$ waste \\ Part 73 Physical protection of plants and materials \\ Part 74 Material control and accounting of special nuclear material \\ Part 75 Safeguards on nuclear material-implementation of US/IAEA agreement \\ Part 76 Certification of gaseous diffusion plants \\ Part 81 \\ Part 95 \\ Part 100 \\ Part 110 \\ Standard specifications for the granting of patent licenses \\ Facility security clearance and safeguarding of national security information and restricted data Reactor site criteria \\ Part 140 \\ Part 150 \\ Part 160 \\ Part 170 \\ Part 171 \\ Parts 172-199 \\ Export and import of nuclear equipment and material \\ Financial protection requirements and indemnity agreements \\ Exemptions and continued regulatory authority in Agreement States and in offshore waters under section 274 \\ Trespassing on Commission property \\ Fees for facilities, materials, import and export licenses, and other regulatory services under the Atomic Energy Act of 1954, as amended \\ Annual fees for reactor licenses and fuel cycle licenses and materials licenses, including holders of certificates of compliance, registrations, and quality assurance program approvals and government agencies licensed by the NRC \\ [Reserved]}

\subsubsection{Fact Sheet on Uranium Enrichment, May 2009, http://www.nrc.gov/reading-rm/doc-collections/fact- sheets/enrichment.html}

Under the Atomic Energy Act, as amended, NRC must license a uranium enrichment plant under 10 CFR Parts 40 (source material) and 70 (special nuclear material). Before an applicant can begin construction of a plant, NRC must issue a license for construction and operation. To issue a license, the NRC must prepare an Environmental Impact Statement (EIS) and a Safety Evaluation Report for the project. NRC must also conduct a formal hearing before issuing a license, and members of the public may request status as intervenors in order to raise important safety or environmental issues about the proposed plant.

\subsubsection{Part 50 - Domestic Licensing of Production and Utilization Facilities}

This is the old reactor licensing process, as well as the licensing regulation for many non-power-reactor facilities.

The definition of "nuclear reactor" in this part would not include pure fusion reactors. Assuming design for $k$-effective $<1$, then neither fusion-fission hybrid nor accelerator-driven systems would be "nuclear reactors" either.

The italics below are in the original, denoting the term being defined. 


\subsection{Definitions.}

Atomic weapon means any device utilizing atomic energy, exclusive of the means for transporting or propelling the device (where such means is a separable and divisible part of the device), the principal purpose of which is for use as, or for development of, a weapon, a weapon prototype, or a weapon test device.

Fuel acceptable to the Commission means that the fuel replacing the existing HEU fuel in a specific nonpower reactor (1) meets the operating requirements of the existing license or, through appropriate NRC safety review and approval, can be used in a manner which protects public health and safety and promotes the common defense and security; and (2) meets the Commission's policy of limiting, to the maximum extent possible, the use of HEU fuel in that reactor.

Highly enriched uranium (HEU) fuel means fuel in which the weight percent of U-235 in the uranium is $20 \%$ or greater. Target material, special instrumentation, or experimental devices using HEU are not included.

Low enriched uranium ( $L E U$ ) fuel means fuel in which the weight percent of U-235 in the uranium is less than $20 \%$.

Non-power reactor means a research or test reactor licensed under $\S \S 50.21$ (c) or 50.22 of this part for research and development.

Nuclear reactor means an apparatus, other than an atomic weapon, designed or used to sustain nuclear fission in a self-supporting chain reaction.

Production facility means:

(1) Any nuclear reactor designed or used primarily for the formation of plutonium or uranium-233; or

(2) Any facility designed or used for the separation of the isotopes of plutonium, except laboratory scale facilities designed or used for experimental or analytical purposes only; or

(3) Any facility designed or used for the processing of irradiated materials containing special nuclear material, except

(i) laboratory scale facilities designed or used for experimental or analytical purposes,

(ii) facilities in which the only special nuclear materials contained in the irradiated material to be processed are uranium enriched in the isotope U-235 and plutonium produced by the irradiation, if the material processed contains not more than $10^{-6}$ grams of plutonium per gram of U-235 and has fission product activity not in excess of 0.25 millicuries of fission products per gram of U235 , and

(iii) facilities in which processing is conducted pursuant to a license issued under parts 30 and 70 of this chapter, or equivalent regulations of an Agreement State, for the receipt, possession, use, and transfer of irradiated special nuclear material, which authorizes the processing of the irradiated material on a batch basis for the separation of selected fission products and limits the process batch to not more than 100 grams of uranium enriched in the isotope 235 and not more than 15 grams of any other special nuclear material.

Special nuclear material means 
(1) plutonium, uranium-233, uranium enriched in the isotope-233 or in the isotope-235, and any other material which the Commission, pursuant to the provisions of section 51 of the act, determines to be special nuclear material, but does not include source material; or

(2) any material artificially enriched by any of the foregoing, but does not include source material.

Unique purpose means a project, program, or commercial activity which cannot reasonably be accomplished without the use of HEU fuel, and may include: (1) A specific experiment, program, or commercial activity (typically long-term) that significantly serves the U.S. national interest and cannot be accomplished without the use of HEU fuel; (2) Reactor physics or reactor development based explicitly on the use of HEU fuel; (3) Research projects based on neutron flux levels or spectra attainable only with HEU fuel; or (4) A reactor core of special design that could not perform its intended function without using HEU fuel.

Utilization facility means any nuclear reactor other than one designed or used primarily for the formation of plutonium or U-233.

\subsection{Contents of applications; general information.}

(g) If the application is for an operating license or combined license for a nuclear power reactor, or if the application is for an early site permit and contains plans for coping with emergencies under $\S 52.17(\mathrm{~b})(2)$ (ii) of this chapter, the applicant shall submit radiological emergency response plans of State and local governmental entities in the United States that are wholly or partially within the plume exposure pathway emergency planning zone (EPZ), 4 as well as the plans of State governments wholly or partially within the ingestion pathway EPZ.5 If the application is for an early site permit that, under 10 CFR 52.17(b)(2)(i), proposes major features of the emergency plans describing the EPZs, then the descriptions of the EPZs must meet the requirements of this paragraph. Generally, the plume exposure pathway EPZ for nuclear power reactors shall consist of an area about 10 miles $(16 \mathrm{~km})$ in radius and the ingestion pathway EPZ shall consist of an area about 50 miles $(80 \mathrm{~km})$ in radius. The exact size and configuration of the EPZs surrounding a particular nuclear power reactor shall be determined in relation to the local emergency response needs and capabilities as they are affected by such conditions as demography, topography, land characteristics, access routes, and jurisdictional boundaries. The size of the EPZs also may be determined on a case-by-case basis for gas-cooled reactors and for reactors with an authorized power level less than $250 \mathrm{MW}$ thermal. The plans for the ingestion pathway shall focus on such actions as are appropriate to protect the food ingestion pathway.

\subsection{Limitations on the use of highly enriched uranium (HEU) in domestic non-power reactors}

(a) Applicability. The requirements of this section apply to all non-power reactors.

(b) Requirements.

(1) The Commission will not issue a construction permit after March 27, 1986 for a non-power reactor where the applicant proposes to use highly enriched uranium (HEU) fuel, unless the applicant demonstrates that the proposed reactor will have a unique purpose as defined in $\S 50.2$.

(2) Unless the Commission has determined, based on a request submitted in accordance with paragraph (c)(1) of this section, that the non-power reactor has a unique purpose, each licensee authorized to possess and use HEU fuel in connection with the reactor's operation shall:

(i) Not initiate acquisition of additional HEU fuel, if low enriched uranium (LEU) fuel acceptable to the Commission for that reactor is available when it proposes that acquisition; and 
(ii) Replace all HEU fuel in its possession with available LEU fuel acceptable to the Commission for that reactor, in accordance with a schedule determined pursuant to paragraph (c)(2) of this section.

(3) If not required by paragraphs (b) (1) and (2) of this section to use LEU fuel, the applicant or licensee must use HEU fuel of enrichment as close to $20 \%$ as is available and acceptable to the Commission.

\subsubsection{Part 52 - Licenses, Certifications, and Approvals for Nuclear Power Plants.}

This is the new licensing process for power reactors. Appendices $A, B, C$, and $D$ are the design certification rules for U.S. Advanced Boiling Water Reactor, System 80+ Design, AP600, and AP1000. This regulation invokes explicitly at 52.0 all other NRC requirements in $10 \mathrm{CFR}$. The author finds nothing in 10CFR52 that speaks to the issues posed for this report.

\subsubsection{Part 60 - Disposal of High-Level Radioactive Wastes in Geologic Repositories.}

Italics below are in the original.

\subsection{Purpose and scope.}

This part prescribes rules governing the licensing (including issuance of a construction authorization) of the U.S. Department of Energy to receive and possess source, special nuclear, and byproduct material at a geologic repository operations area sited, constructed, or operated in accordance with the Nuclear Waste Policy Act of 1982, as amended. This part does not apply to any activity licensed under another part of this chapter. This part does not apply to the licensing of the U.S. Department of Energy to receive and possess source, special nuclear, and byproduct material at a geologic repository operations area sited, constructed, or operated at Yucca Mountain, Nevada, in accordance with the Nuclear Waste Policy Act of 1992, as amended, and the Energy Policy Act of 1992, subject to part 63 of this chapter. This part also gives notice to all persons who knowingly provide to any licensee, applicant, contractor, or subcontractor, components, equipment, materials, or other goods or services, that relate to a licensee's or applicant's activities subject to this part, that they may be individually subject to NRC enforcement action for violation of $\S 60.11$.

\subsection{Definitions.}

High-level radioactive waste or HLW means: (1) Irradiated reactor fuel, (2) liquid wastes resulting from the operation of the first cycle solvent extraction system, or equivalent, and the concentrated wastes from subsequent extraction cycles, or equivalent, in a facility for reprocessing irradiated reactor fuel, and (3) solids into which such liquid wastes have been converted.

\subsection{Performance of the geologic repository operations area through permanent closure.}

(b) Retrievability of waste.

(1) The geologic repository operations area shall be designed to preserve the option of waste retrieval throughout the period during which wastes are being emplaced and, thereafter, until the completion of a performance confirmation program and Commission review of the information obtained from such a program. To satisfy this objective, the geologic repository operations area shall be designed so that any or all of the emplaced waste could be retrieved on a reasonable schedule starting at any time up to 50 years after the waste emplacement operations are initiated, unless a different time period is 
approved or specified by the Commission. This different time period may be established on a caseby-case basis consistent with the emplacement schedule and the planned performance confirmation program.

\subsubsection{Part 61 - Licensing Requirements for Land Disposal of Radioactive Waste.}

\subsection{Waste classification.}

(a) Classification of waste for near surface disposal.

(1) Considerations. Determination of the classification of radioactive waste involves two considerations. First, consideration must be given to the concentration of long-lived radionuclides (and their shorter-lived precursors) whose potential hazard will persist long after such precautions as institutional controls, improved waste form, and deeper disposal have ceased to be effective. These precautions delay the time when long-lived radionuclides could cause exposures. In addition, the magnitude of the potential dose is limited by the concentration and availability of the radionuclide at the time of exposure. Second, consideration must be given to the concentration of shorter-lived radionuclides for which requirements on institutional controls, waste form, and disposal methods are effective.

(2) Classes of waste.

(i) Class A waste is waste that is usually segregated from other waste classes at the disposal site. The physical form and characteristics of Class A waste must meet the minimum requirements set forth in $\S 61.56$ (a). If Class A waste also meets the stability requirements set forth in $\S 61.56(\mathrm{~b})$, it is not necessary to segregate the waste for disposal.

(ii) Class B waste is waste that must meet more rigorous requirements on waste form to ensure stability after disposal. The physical form and characteristics of Class B waste must meet both the minimum and stability requirements set forth in $\S 61.56$.

(iii) Class $\mathrm{C}$ waste is waste that not only must meet more rigorous requirements on waste form to ensure stability but also requires additional measures at the disposal facility to protect against inadvertent intrusion. The physical form and characteristics of Class $\mathrm{C}$ waste must meet both the minimum and stability requirements set forth in $\S 61.56$.

(iv) Waste that is not generally acceptable for near-surface disposal is waste for which form and disposal methods must be different, and in general more stringent, than those specified for Class $\mathrm{C}$ waste. In the absence of specific requirements in this part, such waste must be disposed of in a geologic repository as defined in part 60 or 63 of this chapter unless proposals for disposal of such waste in a disposal site licensed pursuant to this part are approved by the Commission.

(3) Classification determined by long-lived radionuclides. If radioactive waste contains only radionuclides listed in Table 1, classification shall be determined as follows:

(i) If the concentration does not exceed 0.1 times the value in Table 1, the waste is Class A.

(ii) If the concentration exceeds 0.1 times the value in Table 1 but does not exceed the value in Table 1, the waste is Class C.

(iii) If the concentration exceeds the value in Table 1, the waste is not generally acceptable for near-surface disposal. 
(iv) For wastes containing mixtures of radionuclides listed in Table 1, the total concentration shall be determined by the sum of fractions rule described in paragraph (a)(7) of this section.

Table 8 of report. Table 1 (of 10CFR61).

\begin{tabular}{|l|r|}
\hline \multicolumn{1}{|c|}{ Radionuclide } & \multicolumn{1}{c|}{$\begin{array}{c}\text { Concentration curies per } \\
\text { cubic meter }\end{array}$} \\
\hline C-14 & 8 \\
\hline C-14 in activated metal & 80 \\
\hline Ni-59 in activated metal & 220 \\
\hline Nb-94 in activated metal & 0.2 \\
\hline Tc-99 & 3 \\
\hline I-129 & 0.08 \\
\hline Alpha emitting transuranic nuclides with half-life greater than 5 years & ${ }^{1} 100$ \\
\hline Pu-241 & ${ }^{13,500}$ \\
\hline Cm-242 & ${ }^{1} 20,000$ \\
\hline
\end{tabular}

${ }^{1}$ Units are nanocuries per gram.

(4) Classification determined by short-lived radionuclides. If radioactive waste does not contain any of the radionuclides listed in Table 1, classification shall be determined based on the concentrations shown in Table 2. However, as specified in paragraph (a)(6) of this section, if radioactive waste does not contain any nuclides listed in either Table 1 or 2 , it is Class A.

(i) If the concentration does not exceed the value in Column 1, the waste is Class A.

(ii) If the concentration exceeds the value in Column 1, but does not exceed the value in Column 2 , the waste is Class B.

(iii) If the concentration exceeds the value in Column 2, but does not exceed the value in Column 3 , the waste is Class C.

(iv) If the concentration exceeds the value in Column 3 , the waste is not generally acceptable for near-surface disposal.

(v) For wastes containing mixtures of the nuclides listed in Table 2, the total concentration shall be determined by the sum of fractions rule 
Table 9 of report. Table 2 (of 10CFR61).

\begin{tabular}{|c|c|c|c|}
\hline \multirow{2}{*}{ Radionuclide } & \multicolumn{3}{|c|}{ Concentration, curies per cubic meter } \\
\hline & Col. 1 & Col. 2 & Col. 3 \\
\hline Total of all nuclides with less than 5 year half-life & 700 & $\left({ }^{1}\right)$ & $\left({ }^{1}\right)$ \\
\hline $\mathrm{H}-3$ & 40 & $\left({ }^{1}\right)$ & $\left({ }^{1}\right)$ \\
\hline Co-60 & 700 & $\left({ }^{1}\right)$ & $\left({ }^{1}\right)$ \\
\hline Ni-63 & 3.5 & 70 & 700 \\
\hline Ni-63 in activated metal & 35 & 700 & 7000 \\
\hline Sr-90 & 0.04 & 150 & 7000 \\
\hline Cs-137 & 1 & 44 & 4600 \\
\hline
\end{tabular}

1 There are no limits established for these radionuclides in Class B or C wastes. Practical considerations such as the effects of external radiation and internal heat generation on transportation, handling, and disposal will limit the concentrations for these wastes. These wastes shall be Class B unless the concentrations of other nuclides in Table 2 determine the waste to the Class $\mathrm{C}$ independent of these nuclides.

(5) Classification determined by both long- and short-lived radionuclides. If radioactive waste contains a mixture of radionuclides, some of which are listed in Table 1, and some of which are listed in Table 2, classification shall be determined as follows:

(i) If the concentration of a nuclide listed in Table 1 does not exceed 0.1 times the value listed in Table 1, the class shall be that determined by the concentration of nuclides listed in Table 2 .

(ii) If the concentration of a nuclide listed in Table 1 exceeds 0.1 times the value listed in Table 1 but does not exceed the value in Table 1, the waste shall be Class $\mathrm{C}$, provided the concentration of nuclides listed in Table 2 does not exceed the value shown in Column 3 of Table 2.

(6) Classification of wastes with radionuclides other than those listed in Tables 1 and 2. If radioactive waste does not contain any nuclides listed in either Table 1 or 2, it is Class A.

(7) The sum of the fractions rule for mixtures of radionuclides. For determining classification for waste that contains a mixture of radionuclides, it is necessary to determine the sum of fractions by dividing each nuclide's concentration by the appropriate limit and adding the resulting values. The appropriate limits must all be taken from the same column of the same table. The sum of the fractions for the column must be less than 1.0 if the waste class is to be determined by that column. Example: A waste contains Sr-90 in a concentration of $50 \mathrm{Ci} / \mathrm{m}^{3}$. and Cs- 137 in a concentration of $22 \mathrm{Ci} / \mathrm{m}^{3}$. Since the concentrations both exceed the values in Column 1, Table 2, they must be compared to Column 2 values. For Sr-90 fraction 50/150=0.33; for Cs- 137 fraction, 22/44=0.5; the sum of the fractions $=0.83$. Since the sum is less than 1.0 , the waste is Class B.

(8) Determination of concentrations in wastes. The concentration of a radionuclide may be determined by indirect methods such as use of scaling factors which relate the inferred concentration of one radionuclide to another that is measured, or radionuclide material accountability, if there is reasonable assurance that the indirect methods can be correlated with actual measurements. The concentration of a radionuclide may be averaged over the volume of the waste, or weight of the waste if the units are expressed as nanocuries per gram. 


\subsubsection{Part 62 - Criteria and Procedures for Emergency Access to Non-Federal and Regional Low-Level Waste Disposal Facilities.}

Italics below are in the original.

\subsection{Definitions.}

Low-level radioactive waste $(L L W)$ means radioactive material that -

(1) Is not high-level radioactive waste, spent nuclear fuel, or byproduct material (as defined in paragraphs

(2), (3), and (4) of the definition of Byproduct Material set forth in $\S 20.1003$ of this chapter); and

(2) The NRC, consistent with existing law and in accordance with paragraph (1) of this definition, classifies as low-level radioactive waste.

\subsubsection{Part 63 - Disposal of High-Level Radioactive Wastes in a Geologic Repository at Yucca Mountain, Nevada.}

\subsection{Definitions}

High-level radioactive waste or HLW means:

(1) The highly radioactive material resulting from the reprocessing of spent nuclear fuel, including liquid waste produced directly in reprocessing and any solid material derived from such liquid waste that contains fission products in sufficient concentrations;

(2) Irradiated reactor fuel; and

(3) Other highly radioactive material that the Commission, consistent with existing law, determines by rule requires permanent isolation.

63.111 Performance objectives for the geologic repository operations area through permanent closure.

(e) Retrievability of waste.

(1) The geologic repository operations area must be designed to preserve the option of waste retrieval throughout the period during which wastes are being emplaced and thereafter, until the completion of a performance confirmation program and Commission review of the information obtained from such a program. To satisfy this objective, the geologic repository operations area must be designed so that any or all of the emplaced waste could be retrieved on a reasonable schedule starting at any time up to 50 years after waste emplacement operations are initiated, unless a different time period is approved or specified by the Commission. This different time period may be established on a case-by-case basis consistent with the emplacement schedule and the planned performance confirmation program.

\subsubsection{Part 70 - Domestic Licensing of Special Nuclear Material.}

\section{Italics below are in the original.}

\subsection{Definitions}

Critical mass of special nuclear material (SNM), as used in Subpart $\mathrm{H}$, means special nuclear material in a quantity exceeding 700 grams of contained uranium-235; 520 grams of uranium-233; 450 grams of 
plutonium; 1500 grams of contained uranium-235, if no uranium enriched to more than 4 percent by weight of uranium-235 is present; 450 grams of any combination thereof; or one-half such quantities if massive moderators or reflectors made of graphite, heavy water, or beryllium may be present.

Effective kilograms of special nuclear material means: (1) For plutonium and uranium-233 their weight in kilograms; (2) For uranium with an enrichment in the isotope U-235 of $0.01(1 \%)$ and above, its element weight in kilograms multiplied by the square of its enrichment expressed as a decimal weight fraction; and (3) For uranium with an enrichment in the isotope $U-235$ below $0.01(1 \%)$, by its element weight in kilograms multiplied by 0.0001 .

Formula quantity means strategic special nuclear material in any combination in a quantity of 5000 grams or more computed by the formula, grams $=($ grams contained U-235) +2.5 (grams U-233+grams plutonium). This class of material is sometimes referred to as a Category I quantity of material.

Source material means source material as defined in section 11z. of the Act and in the regulations contained in part 40 of this chapter;

Special nuclear material means (1) plutonium, uranium 233, uranium enriched in the isotope 233 or in the isotope 235, and any other material which the Commission, pursuant to the provisions of section 51 of the act, determines to be special nuclear material, but does not include source material; or (2) any material artificially enriched by any of the foregoing but does not include source material;

Special nuclear material of low strategic significance means:

(1) Less than an amount of special nuclear material of moderate strategic significance as defined in paragraph (1) of the definition of strategic nuclear material of moderate strategic significance in this section, but more than 15 grams of uranium-235 (contained in uranium enriched to 20 percent or more in U-235 isotope) or 15 grams of uranium-233 or 15 grams of plutonium or the combination of 15 grams when computed by the equation, grams $=($ grams contained U-235) $+($ grams plutonium $)+$ (grams U-233); or

(2) Less than 10,000 grams but more than 1,000 grams of uranium-235 (contained in uranium enriched to 10 percent or more but less than 20 percent in the U-235 isotope); or

(3) 10,000 grams or more of uranium-235 (contained in uranium enriched above natural but less than 10 percent in the $\mathrm{U}-235$ isotope).

This class of material is sometimes referred to as a Category III quantity of material.

Special nuclear material of moderate strategic significance means:

(1) Less than a formula quantity of strategic special nuclear material but more than 1,000 grams of uranium-235 (contained in uranium enriched to 20 percent or more in the U-235 isotope) or more than 500 grams of uranium-233 or plutonium, or in a combined quantity of more than 1,000 grams when computed by the equation, grams $=($ grams contained U-235) $+2($ grams U-233 + grams plutonium); or

(2) 10,000 grams or more of uranium-235 (contained in uranium enriched to 10 percent or more but less than 20 percent in the U-235 isotope).

This class of material is sometimes referred to as a Category II quantity of material.

\subsection{Contents of applications.}


(j)(1) Each application for a license to possess or use at any site or contiguous sites subject to control by the licensee uranium-235 (contained in uranium enriched to 20 percent or more in the uranium-235 isotope), uranium-233, or plutonium alone or in any combination in a quantity of 5,000 grams or more computed by the formula, grams $=($ grams contained $U-235)+2.5$ (grams $U-233+$ grams plutonium $)$ other than a license for possession or use of this material in the operation of a nuclear reactor licensed pursuant to part 50 of this chapter, must include a licensee safeguards contingency plan for dealing with threats, thefts, and radiological sabotage, as defined in part 73 of this chapter, relating to nuclear facilities licensed under part 50 of this chapter or to the possession of special nuclear material licensed under this part.

(k) Each application for a license to possess or use at any site or contiguous sites subject to licensee control, special nuclear material of moderate strategic significance or $10 \mathrm{~kg}$ or more of special nuclear material of low strategic significance as defined under $\$ 70.4$, other than a license for possession or use of this material in the operation of a nuclear power reactor licensed pursuant to part 50 of this chapter, must include a physical security plan that demonstrates how the applicant plans to meet the requirements of paragraphs (d), (e), (f), and ( $\mathrm{g}$ ) of $\S 73.67$ of this chapter, as appropriate. The licensee shall retain a copy of this physical security plan as a record for the period during which the licensee possesses the appropriate type and quantity of special nuclear material under each license, and if any portion of the plan is superseded, retain that superseded portion of the plan for 3 years after the effective date of the change.

\subsection{Conditions of licenses.}

(a) Each license shall contain and be subject to the following conditions:

(5) No special nuclear material may be used in any utilization or production facility except in accordance with the provisions of the Act;

(6) The licensee shall not use the special nuclear material to construct an atomic weapon or any component of an atomic weapon;

\subsection{Violations.}

(a) The Commission may obtain an injunction or other court order to prevent a violation of the provisions of--

(1) The Atomic Energy Act of 1954, as amended;

(2) Title II of the Energy Reorganization Act of 1974, as amended; or

(3) A regulation or order issued pursuant to those Acts.

(b) The Commission may obtain a court order for the payment of a civil penalty imposed under section 234 of the Atomic Energy Act:

(1) For violations of--

(i) Sections 53, 57, 62, 63, 81, 82, 101, 103, 104, 107, or 109 of the Atomic Energy Act of 1954, as amended;

(ii) Section 206 of the Energy Reorganization Act;

(iii) Any rule, regulation, or order issued pursuant to the sections specified in paragraph (b)(1)(i) of this section; 
(iv) Any term, condition, or limitation of any license issued under the sections specified in paragraph (b)

(1)(i) of this section.

(2) For any violation for which a license may be revoked under section 186 of the Atomic Energy Act of 1954 , as amended.

[57 FR 55077, Nov. 24, 1992. Redesignated at 65 FR 56226, Sept. 18, 2000]

\subsection{Criminal penalties.}

(a) Section 223 of the Atomic Energy Act of 1954, as amended, provides for criminal sanctions for willful violation of, attempted violation of, or conspiracy to violate, any regulation issued under sections $161 \mathrm{~b}$, 161 , or 1610 of the Act. For purposes of section 223, all the regulations in part 70 are issued under one or more of sections $161 \mathrm{~b}, 161 \mathrm{i}$, or $161 \mathrm{o}$, except for the sections listed in paragraph (b) of this section.

(b) The regulations in part 70 that are not issued under sections $161 \mathrm{~b}, 161 \mathrm{i}$, or $161 \mathrm{o}$, for the purposes of section 223 are as follows: $\S 70.1,70.2,70.4,70.5,70.6,70.8,70.11,70.12,70.13,70.14,70.17,70.18$, $70.23,70.31,70.33,70.34,70.35,70.37,70.66,70.73,70.76,70.81,70.82,70.63,70.91$, and 70.92 .

[57 FR 55077, Nov. 24, 1992. Redesignated and amended at 65 FR 56226, Sept. 18, 2000]

\subsubsection{Part 71 - Packaging and Transportation of Radioactive Material.}

Italics below are in the original.

\subsection{Definitions.}

Low toxicity alpha emitters means natural uranium, depleted uranium, natural thorium; uranium-235, uranium-238, thorium-232, thorium-228 or thorium-230 when contained in ores or physical or chemical concentrates or tailings; or alpha emitters with a half-life of less than 10 days.

Fissile material means the radionuclides uranium-233, uranium-235, plutonium-239, and plutonium-241, or any combination of these radionuclides. Fissile material means the fissile nuclides themselves, not material containing fissile nuclides. Unirradiated natural uranium and depleted uranium and natural uranium or depleted uranium, that has been irradiated in thermal reactors only, are not included in this definition. Certain exclusions from fissile material controls are provided in $§ 71.15$.

\subsubsection{Part 72 - Licensing Requirements for the Independent Storage of Spent Nuclear Fuel, High Level Radioactive Waste, and Reactor-Related Greater than Class C Waste.}

\subsection{Definitions.}

Independent spent fuel storage installation or ISFSI means a complex designed and constructed for the interim storage of spent nuclear fuel, solid reactor-related GTCC waste, and other radioactive materials associated with spent fuel and reactor-related GTCC waste storage. An ISFSI which is located on the site of another facility licensed under this part or a facility licensed under part 50 of this chapter and which shares common utilities and services with that facility or is physically connected with that other facility may still be considered independent.

Monitored Retrievable Storage Installation or MRS means a complex designed, constructed, and operated by DOE for the receipt, transfer, handling, packaging, possession, safeguarding, and storage of spent 
nuclear fuel aged for at least one year, solidified high-level radioactive waste resulting from civilian nuclear activities, and solid reactor-related GTCC waste, pending shipment to a HLW repository or other disposal.

Source material means--

(1) Uranium or thorium, or any combination thereof, in any physical or chemical form or

(2) Ores that contain by weight one-twentieth of one percent $(0.05 \%)$ or more of:

(i) Uranium,

(ii) Thorium, or

(iii) Any combination thereof.

Spent Nuclear Fuel or Spent Fuel means fuel that has been withdrawn from a nuclear reactor following irradiation, has undergone at least one year's decay since being used as a source of energy in a power reactor, and has not been chemically separated into its constituent elements by reprocessing. Spent fuel includes the special nuclear material, byproduct material, source material, and other radioactive materials associated with fuel assemblies.

\subsection{General considerations.}

(b) The ISFSI must be designed to store spent fuel and/or solid reactor-related GTCC waste.

(1) Reactor-related GTCC waste may not be stored in a cask that also contains spent fuel. This restriction does not include radioactive materials that are associated with fuel assemblies (e.g., control rod blades or assemblies, thimble plugs, burnable poison rod assemblies, or fuel channels);

(c) The MRS must be designed to store spent fuel, solid high-level radioactive waste, and/or solid reactorrelated GTCC waste.

(1) Reactor-related GTCC waste may not be stored in a cask that also contains spent fuel. This restriction does not include radioactive materials associated with fuel assemblies (e.g., control rod blades or assemblies, thimble plugs, burnable poison rod assemblies, or fuel channels);

\subsubsection{Part 73 - Physical Protection of Plants and Materials.}

Same definitions of SNM, SNM-low, SNM-moderate as elsewhere

The performance objectives depend on whether the material is SNM, Strategic SNM (aka category I), SNM of moderate strategic significance (aka category II) or SNM of low strategic significance (aka category III). For category II and III, there were clauses for plutonium above 80\% Pu238. Specifically, the requirements for cat II and III are waived.

Nothing is forbidden per se, there is even a clause that states that plans for MOX over $20 \%$ Pu would be reviewed by the Commission on a case by case basis.

Italics below are in the original.

\subsection{Exemptions for certain quantities and kinds of special nuclear material.}

A licensee is exempt from the requirements of 10 CFR part 26 and $73.20,73.25,73.26,73.27,73.45$, $73.46,73.70$ and 73.72 with respect to the following special nuclear material: 
(a) Uranium-235 contained in uranium enriched to less than 20 percent in the U-235 isotope:

(b) Special nuclear material which is not readily separable from other radioactive material and which has a total external radiation dose rate in excess of 100 rems per hour at a distance of 3 feet from any accessible surface without intervening shielding; and

(c) Special nuclear material in a quantity not exceeding 350 grams of uranium-235, uranium-233, plutonium, or a combination thereof, possessed in any analytical, research, quality control, metallurgical or electronic laboratory.

(d) Special nuclear material that is being transported by the United States Department of Energy transport system.

(e) Special nuclear material at non-power reactors.

\subsection{Transportation physical protection systems, subsystems, components, and procedures.}

(f)(2) All transfers shall be protected by at least seven armed escorts or other armed personnel--one of whom shall serve as commander. At least five of the armed personnel (including the commander) shall be available to protect the shipment and at least three of the five shall keep the strategic special nuclear material under continuous surveillance while it is at the transfer point. The two remaining armed personnel shall take up positions at a remote monitoring location. The remote location may be a radioequipped vehicle or a nearby place, apart from the shipment area, so that a single act cannot remove the capability of the personnel protecting the shipment for calling for assistance.

\subsection{Requirements for physical protection of irradiated reactor fuel in transit.}

(a) Performance objectives. (1) Each licensee who transports, or delivers to a carrier for transport, in a single shipment, a quantity of irradiated reactor fuel in excess of 100 grams in net weight of irradiated fuel, exclusive of cladding or other structural or packaging material, which has a total external radiation dose rate in excess of 100 rems per hour at a distance of 3 feet from any accessible surface without intervening shielding, shall establish and maintain, or make arrangements for, and assure the proper implementation of, a physical protection system for shipments of such material that will achieve the following objectives"

\subsection{Requirements for physical protection of licensed activities.}

Each licensee who is not subject to $\S 73.51$, but who possesses, uses, or stores formula quantities of strategic special nuclear material that are not readily separable from other radioactive material and which have total external radiation dose rates in excess of 100 rems per hour at a distance of 3 feet from any accessible surfaces without intervening shielding other than at nuclear reactor facility licensed under parts 50 or 52 of this chapter, shall comply with the following:

\subsection{Requirements for physical protection of licensed activities in nuclear power reactors against radiological sabotage.}

(1) Facilities using mixed-oxide (MOX) fuel assemblies containing up to 20 weight percent plutonium dioxide (PuO2).

(1) Commercial nuclear power reactors licensed under 10 CFR parts 50 or 52 and authorized to use special nuclear material in the form of MOX fuel assemblies containing up to 20 weight percent $\mathrm{PuO} 2$ shall, in addition to meeting the requirements of this section, protect un-irradiated MOX fuel assemblies against theft or diversion as described in this paragraph. 
(2) Commercial nuclear power reactors authorized to use MOX fuel assemblies containing up to 20 weight percent $\mathrm{PuO} 2$ are exempt from the requirements of $\S \S 73.20,73.45$, and 73.46 for the onsite physical protection of un-irradiated MOX fuel assemblies.

(B) The licensee shall store un-irradiated MOX fuel assemblies only within a spent fuel pool, located within a vital area, so that access to the un-irradiated MOX fuel assemblies requires passage through at least two physical barriers and the water barrier combined with the additional measures detailed in this section.

(7) MOX fuel assemblies containing greater than 20 weight percent $\mathrm{PuO}_{2}$.

(i) Requests for the use of MOX fuel assemblies containing greater than 20 weight percent $\mathrm{PuO} 2$ shall be reviewed and approved by the Commission before receipt of MOX fuel assemblies.

(ii) Additional measures for the physical protection of un-irradiated MOX fuel assemblies containing greater than 20 weight percent $\mathrm{PuO} 2$ shall be determined by the Commission on a case-by-case basis and documented through license amendment in accordance with $10 \mathrm{CFR}$ 50.90 .

73.67 Licensee fixed site and in-transit requirements for the physical protection of special nuclear material of moderate and low strategic significance.

(b)(1) A licensee is exempt from the requirements of this section to the extent that he possesses, uses, or transports:

(i) Special nuclear material which is not readily separable from other radioactive material and which has a total external radiation dose rate in excess of 100 rems per hour at a distance of 3 feet from any accessible surface without intervening shielding, or

(ii) Sealed plutonium-beryllium neutron sources totaling 500 grams or less contained plutonium at any one site or contiguous sites, or

(iii) Plutonium with an isotopic concentration exceeding 80 percent in plutonium-238.

\subsubsection{Part 74 - Material Control and Accounting of Special Nuclear Material.}

Table 10 of report. Table constructed from the text of 10CFR74.

\begin{tabular}{|l|c|c|c|}
\hline \multicolumn{1}{|c|}{ Material } & \multicolumn{1}{|c|}{$\begin{array}{c}\text { Strategic special } \\
\text { nuclear material }\end{array}$} & $\begin{array}{c}\text { Special nuclear } \\
\text { material of moderate } \\
\text { strategic significance }\end{array}$ & $\begin{array}{c}\text { Special nuclear } \\
\text { material of low } \\
\text { strategic significance }\end{array}$ \\
\hline $\begin{array}{l}\text { Analogous IAEA } \\
\text { categories }\end{array}$ & Category I & Category II & Category III \\
\hline Plutonium & $\mathrm{X} \geq 2 \mathrm{~kg}$ & $2 \mathrm{~kg}>\mathrm{X}>500 \mathrm{~g}$ & $500 \mathrm{~g} \geq \mathrm{X}>15 \mathrm{~g}$ \\
\hline $\begin{array}{l}\text { Uranium-235 } \\
>20 \% \mathrm{U} 235\end{array}$ & $\mathrm{X} \geq 5 \mathrm{~kg}$ & $5 \mathrm{~kg}>\mathrm{X}>1 \mathrm{~kg}$ & $1 \mathrm{~kg} \geq \mathrm{X}>15 \mathrm{~g}$ \\
$10-20 \% \mathrm{U} 235$ & $\mathrm{X} \geq 10 \mathrm{~kg}$ & $10 \mathrm{~kg}>\mathrm{X}>1 \mathrm{~kg}$ \\
$\begin{array}{l}\text { Above natural but less } \\
\text { than } 10 \% \mathrm{U} 235\end{array}$ & & $\mathrm{X} \geq 10 \mathrm{~kg}$ \\
\hline Uranium-233 & $\mathrm{X} \geq 2 \mathrm{~kg}$ & $2 \mathrm{~kg}>\mathrm{X}>500 \mathrm{~g}$ & $500 \mathrm{~g} \geq \mathrm{X}>15 \mathrm{~g}$ \\
\hline
\end{tabular}


Strategic special nuclear material is a "formula quantity" of $5 \mathrm{~kg}=$ grams contained U235 +2.5 (grams U233+ grams plutonium). So, $2 \mathrm{~kg}$ of plutonium or uranium 233 is a "formula quantity"

Special nuclear material of moderate strategic significance is more than $1 \mathrm{~kg}=$ grams contained U235 + 2 (grams U233+ grams plutonium), so that $500 \mathrm{~g}$ is the threshold for plutonium or U233.

At 74.2 the scope is defined to apply to who possesses special nuclear material in a quantity of one gram or more of contained uranium-235, uranium-233, or plutonium; or who transfers or receives a quantity of special nuclear material of one gram or more of contained uranium-235, uranium-233, or plutonium.

\section{At 74.4 , there are some interesting definitions}

Category IA material means SSNM directly useable in the manufacture of a nuclear explosive device, except if:

(1) The dimensions are large enough (at least two meters in one dimension, greater than one meter in each of two dimensions, or greater than $25 \mathrm{~cm}$ in each of three dimensions) to preclude hiding the item on an individual;

(2) The total weight of an encapsulated item of SSNM is such that it cannot be carried inconspicuously by one person (i.e., at least 50 kilograms gross weight); or

(3) The quantity of SSNM (less than 0.05 formula kilograms) in each container requires protracted diversions to accumulate five formula kilograms.

Effective kilograms of special nuclear material means:

(1) For plutonium and uranium-233 their weight in kilograms;

(2) For uranium with an enrichment in the isotope U235 of 0.01 (1 percent) and above, its element weight in kilograms multiplied by the square of its enrichment expressed as a decimal weight fraction; and

(3) For uranium with an enrichment in the isotope U235 below 0.01 ( 1 percent), its element weight in kilograms multiplied by 0.0001 .

Formula kilogram means SSNM in any combination in a quantity of 1000 grams computed by the formula, grams $=($ grams contained U-235) +2.5 (grams U-233 + grams plutonium).

Formula quantity means strategic special nuclear material in any combination in a quantity of 5,000 grams or more computed by the formula, grams $=$ (grams contained U235) +2.5 (grams U233 + grams plutonium).

Low enriched uranium means uranium enriched below 20 percent in the isotope uranium- 235 .

Special nuclear material means:

(1) Plutonium, uranium-233, uranium enriched in the isotope U233 or in the isotope U235, and any other material which the Commission, pursuant to the provisions of section 51 of the Atomic Energy Act of 1954, as amended, determines to be special nuclear material, but does not include source material; or

(2) Any material artificially enriched by any of the foregoing, but does not include source material.

Special nuclear material of low strategic significance means: 
(1) Less than an amount of special nuclear material of moderate strategic significance, but more than 15 grams of uranium-235 (contained in uranium enriched to 20 percent or more in the U235 isotope) or 15 grams of uranium-233 or 15 grams of plutonium or the combination of 15 grams when computed by the equation, grams $=$ grams contained U235+grams plutonium + grams U233; pr

(2) Less than 10,000 grams but more than 1,000 grams of uranium-235 (contained in uranium enriched to 10 percent or more, but less than 20 percent in the U235 isotope); or

(3) 10,000 grams or more of uranium-235 contained in uranium enriched above natural, but less than 10 percent in the U235 isotope.

Special nuclear material of moderate strategic significance means:

(1) Less than a formula quantity of strategic special nuclear material but more than 1,000 grams of uranium-235 (contained in uranium enriched to 20 percent or more in the U235 isotope) or more than 500 grams of uranium-233 or plutonium or in a combined quantity of more than 1,000 grams when computed by the equation, grams $=($ grams contained U235) +2 (grams U233 + grams plutonium); or

(2) 10,000 grams or more or uranium-235 (contained in uranium enriched to 10 percent or more but less than 20 percent in the U235 isotope).

Strategic special nuclear material means uranium-235 (contained in uranium enriched to 20 percent or more in the U235 isotope), uranium-233, or plutonium.

\subsection{Nuclear material control and accounting for uranium enrichment facilities authorized to produce special nuclear material of low strategic significance.}

(a) General performance objectives. Each licensee who is authorized by this chapter to possess equipment capable of enriching uranium or operate an enrichment facility, and produce, possess, or use more than one effective kilogram of special nuclear material of low strategic significance at any site or contiguous sites, subject to control by the licensee, shall establish, implement, and maintain a NRC approved material control and accounting system that will achieve the following objectives:

(1) Maintain accurate, current, and reliable information of and periodically confirm the quantities and locations of source material and special nuclear material in the licensee's possession;

(2) Protect against and detect production of uranium enriched to 10 percent or more in the isotope U235;

(3) Protect against and detect unauthorized production of uranium of low strategic significance;

(4) Resolve indications of missing uranium;

(5) Resolve indications of production of uranium enriched to 10 percent or more in the isotope U235

(for centrifuge enrichment facilities this requirement does not apply to each cascade during its startup process, not to exceed the first 24 hours);

(6) Resolve indications of unauthorized production of uranium of low strategic significance;

(7) Provide information to aid in the investigation of missing uranium;

(8) Provide information to aid in the investigation of the production of uranium enriched to 10 percent or more in the isotope U235; and

(9) Provide information to aid in the investigation of unauthorized production of uranium of low strategic significance. 
74.41 Nuclear material control and accounting for special nuclear material of moderate strategic significance.

(5) The licensee shall establish, document, and maintain an item control program that:

(i) Provides current knowledge of SNM items with respect to identity, element and isotope content, and stored location; and

(ii) Assures that SNM items are stored and handled, or subsequently measured, in a manner such that unauthorized removal of 200 grams or more of plutonium or uranium-233 or 300 grams or more of uranium-235, as one or more whole items and/or as SNM removed from containers, will be detected.

\subsection{Nuclear material control and accounting for strategic special nuclear material.}

\subsubsection{Part 75 - Safeguards on Nuclear Material - Implementation of US/IAEA Agreement.}

This CFR puts NRC licensed facilities under inspection rules of the IAEA, unless the US Government or NRC deem otherwise.

Even this more recent regulation (last updated December 23,2008) does not differentiate U233 criteria by U233 enrichment levels.

\section{Italics below are in the original.}

\subsection{Scope.}

(a) All persons licensed by the Nuclear Regulatory Commission or an Agreement State, or who hold a certificate of compliance, or construction permit or authorization issued by the Nuclear Regulatory Commission are subject to the requirements of this part. These requirements also apply to all persons who have filed an application with the NRC to construct a facility or to receive source or special nuclear material. Locations determined by the U.S. Government to be associated with activities or information of direct national security significance to the United States are excluded from these requirements. Specifically, these requirements pertain to the following locations and activities of licensees and certificate holders:

\subsection{Exemptions.}

(a) The Commission may, upon application of any interested person or upon its own initiative, grant exemptions from the requirements of this Part that it determines are authorized by law and consistent with the Safeguards Agreement or the Additional Protocol, are not inimical to the common defense and security, and are otherwise in the public interest.

(b) Without limiting the generality of paragraph (a) of this section, the U.S. Government may request from the IAEA an exemption with respect to nuclear material of the following types:

(1) Source and special nuclear material in gram quantities or less as a sensing component in instruments;

(2) Nuclear material used in nonnuclear activities; and

(3) Plutonium with an isotopic concentration of plutonium-238 exceeding 80 percent. 


\subsection{Definitions.}

Nuclear Fuel Cycle-Related Manufacturing and Construction means those activities related to the manufacture or construction of any of the following: Components for separating the isotopes of uranium or enriching uranium in the isotope 235 , zirconium tubes, heavy water or deuterium, nuclear-grade graphite, irradiated fuel casks and canisters, reactor control rods, criticality safe tanks and vessels, irradiated fuel element chopping machines, and hot cells.

Nuclear Fuel Cycle-Related Research and Development means those activities specifically related to any process or system development aspect of any of the following: Conversion of nuclear material; enrichment of nuclear material; nuclear fuel fabrication; reactors; critical facilities; reprocessing of nuclear fuel; and processing of intermediate or high-level waste containing plutonium, high-enriched uranium, or uranium-233.

\subsubsection{Part 76 - Certification of Gaseous Diffusion Plants.}

Repeats the common rules with regard to U235 as a function of U235 enrichment $(<10 \%, 10-20 \%$, $>20 \%$ ). There is nothing analogous with regard to U233. Seems to have been updated last on December 23,2008 .

Italics below are in the original.

\subsection{Definitions.}

National Security Information means information that has been determined pursuant to Executive Order 12356 or any predecessor order to require protection against unauthorized disclosure and that is so designated.

Special nuclear material means:

(1) Plutonium, uranium 233, uranium enriched in the isotope 233 or in the isotope 235, and any other material which the Commission, pursuant to the provisions of Section 51 of the Act, determines to be special nuclear material, but does not include source material; or

(2) Any material artificially enriched in any of the foregoing, but does not include source material.

Special nuclear material of low strategic significance means:

(1) Less than an amount of special nuclear material of moderate strategic significance, as defined in this section, but more than 15 grams of uranium-235 (contained in uranium enriched to 20 percent or more in the U-235 isotope), or 15 grams of uranium-233, or 15 grams of plutonium, or the combination of 15 grams when computed by the equation, grams $=($ grams contained U-235) $+($ grams plutonium $)+($ grams U-233); or

(2) Less than 10,000 grams but more than 1000 grams of uranium-235 (contained in uranium enriched to 10 percent or more but less than 20 percent in the U-235 isotope), or

(3) 10,000 grams or more of uranium-235 (contained in uranium enriched above natural but less than 10 percent in the $U-235$ isotope).

Special nuclear material of moderate strategic significance means:

(1) Less than a formula quantity of strategic special nuclear material but more than 1000 grams of uranium-235 (contained in uranium enriched to 20 percent or more in the U-235 isotope), or more than 
500 grams of uranium-233 or plutonium, or in a combined quantity of more than 1000 grams when computed by the equation, grams $=($ grams contained U-235) +2 (grams U-233 + grams plutonium $)$; or

(2) 10,000 grams or more of uranium-235 (contained in uranium enriched to 10 percent or more but less than 20 percent in the $\mathrm{U}-235$ isotope).

Special nuclear material scrap means the various forms of special nuclear material generated during chemical and mechanical processing, other than recycle material and normal process intermediates, which are unsuitable for use in their present form, but all or part of which will be used after further processing.

Strategic special nuclear material means uranium-235 (contained in uranium enriched to 20 percent or more in the U-235 isotope), uranium-233, or plutonium.

\subsubsection{Part 110 - Export and Import of Nuclear Equipment and Material.}

This part implements the Atomic Energy Act with regard to expert and import. This 10CFR is actually one of the most complex. For example, 110.20 indicates that the NRC will coordinate issuance of a general license with the Executive Branch - the only 10CFR I've read that explicitly shares authority with the Executive Branch of the federal government. See part 110.20, part 110.41.

Another example is that classification of information authority defers to the executive branch, see part 110.2.

Pu under $80 \%$ Pu 238 and HEU have more complicated review and/or restrictions for export.

Italics below are in the original.

\subsection{Definitions.}

Classified Information means Classified National Security Information under Executive Order 13526, as amended, or any predecessor or successor Executive Order and Restricted Data under the Atomic Energy Act.

Embargoed means that no nuclear material or equipment can be exported to certain countries under an NRC general license. Exports to embargoed countries must be pursuant to a specific license issued by the $\mathrm{NRC}$ and require Executive Branch review pursuant to $\S 110.41$.

Executive Branch means the Departments of State, Energy, Defense and Commerce.

General license means an export or import license effective without the filing of a specific application with the Commission or the issuance of licensing documents to a particular person. A general license is a type of license issued through rulemaking by the NRC and is not an exemption from the requirements in this part. A general license does not relieve a person from complying with other applicable NRC, Federal, and State requirements.

High-enriched uranium means uranium enriched to 20 percent or greater in the isotope uranium-235.

Low-enriched uranium means uranium enriched below 20 percent in the isotope uranium- 235 .

Nuclear Referral List (NRL) means the nuclear-related, dual-use commodities on the Commerce Control List that are subject to the nuclear non-proliferation export licensing controls of the Department of Commerce. They are contained in 15 CFR part 774 of the Department of Commerce's Export Administration Regulations and are designated by the symbol (NP) as the reason for control. 
Specific license means an export or import license document issued to a named person and authorizing the export or import of specified nuclear equipment or materials based upon the review and approval of an NRC Form 7 application filed pursuant to this part and other related submittals in support of the application.

\subsection{List of nuclear facilities and equipment under NRC export licensing authority.}

(a) Nuclear reactors and especially designed or prepared equipment and components for nuclear reactors. (See Appendix A to this part.)

(b) Plants for the separation of isotopes of uranium (source material or special nuclear material) including gas centrifuge plants, gaseous diffusion plants, aerodynamic enrichment plants, chemical exchange or ion exchange enrichment plants, laser based enrichment plants, plasma separation enrichment plants, electromagnetic enrichment plants, and especially designed or prepared equipment, other than analytical instruments, for the separation of isotopes of uranium. (See appendices to this part for lists of: gas centrifuge equipment--Appendix B; gaseous diffusion equipment--Appendix C; aerodynamic enrichment equipment--Appendix D; chemical exchange or ion exchange enrichment equipment--Appendix E; laser based enrichment equipment--Appendix F; plasma separation enrichment equipment--Appendix G; and electromagnetic enrichment equipment--Appendix $\mathrm{H}$.)

(c) Plants for the separation of the isotopes of lithium and especially designed or prepared assemblies and components for these plants. (See Appendix $\mathrm{N}$ to this part)

(d) Plants for the reprocessing of irradiated nuclear reactor fuel elements and especially designed or prepared assemblies and components for these plants. (See Appendix I to this part.)

(e) Plants for the fabrication of nuclear reactor fuel elements and especially designed or prepared assemblies and components for these plants. (See Appendix $O$ to this part.)

(f) Plants for the conversion of uranium and plutonium and especially designed or prepared assemblies and components for these plants. (See Appendix $\mathrm{J}$ to this part.)

(g) Plants for the production, separation, or purification of heavy water, deuterium, and deuterium compounds and especially designed or prepared assemblies and components for these plants. (See Appendix $\mathrm{K}$ to this part.)

(h) Plants for the production of special nuclear material using accelerator-driven subcritical assembly systems capable of continuous operation above 5 MWe thermal.

(i) Other nuclear-related commodities are under the export licensing authority of the Department of Commerce.

\subsection{General license information.}

(a) A person may use an NRC general license as authority to export or import nuclear equipment or material, if the nuclear equipment or material to be exported or imported is covered by the NRC general licenses described in $\S \S 110.21$ through 110.27 . If an export or import is not covered by the NRC general licenses described in $\S \S 110.21$ through 110.27, a person must file an application with the Commission for a specific license in accordance with $\S \S 110.31$ through 110.32 .

(b) In response to a petition or on its own initiative, the Commission may issue a general license for export or import if it determines that any exports or imports made under the general license will not be inimical to the common defense and security or constitute an unreasonable risk to the public health and safety and otherwise meet applicable statutory requirements. A general license is issued as a regulation 
after a rulemaking proceeding under subpart $\mathrm{K}$ of this part. Issuance of a general license is coordinated with the Executive Branch.

(c) A general license does not relieve a person from complying with the regulations of other Government agencies applicable to exports or imports under their authority.

(d) A general license for export may not be used if the exporter knows, or has reason to believe, that the material will be used in any illegal activity or any activity related to isotope separation, chemical reprocessing, heavy water production or the fabrication of nuclear fuel containing plutonium, unless these activities are generically authorized under an appropriate agreement for cooperation.

\subsection{Commission review.}

(a) Immediately after receipt of a license application for an export or import requiring a specific license under this part, the Commission will initiate its licensing review and, to the maximum extent feasible, will expeditiously process the application concurrently with any applicable review by the Executive Branch.

(b) The Commissioners shall review a license application for export of the following:

(1) A production or utilization facility.

(2) More than 5 effective kilograms of high-enriched uranium, plutonium or uranium-233.

(3) An export involving assistance to end uses related to isotope separation, chemical reprocessing, heavy water production, advanced reactors, or the fabrication of nuclear fuel containing plutonium, except for exports of source material or low-enriched uranium to EURATOM or Japan for enrichment up to 5 percent in the isotope uranium-235, and those categories of exports which the Commission has approved in advance as constituting permitted incidental assistance.

\subsection{Executive Branch review.}

(a) An application for a license to export the following will be promptly forwarded to the Executive Branch for review:

(1) A production or utilization facility.

(2) More than one effective kilogram of high-enriched uranium or 10 grams of plutonium or uranium233.

(3) Nuclear grade graphite for nuclear end use.

(4) More than $3.7 \mathrm{TBq}$ (100 curies) of tritium, and deuterium oxide (heavy water), other than exports of heavy water to Canada.

(5) One kilogram or more of source or special nuclear material to be exported under the US-IAEA Agreement for Cooperation.

(6) An export involving assistance to end uses related to isotope separation, chemical reprocessing, heavy water production, advanced reactors, or the fabrication of nuclear fuel containing plutonium, except for exports of source material or low-enriched uranium to EURATOM and Japan for enrichment up to 5 percent in the isotope uranium-235, and those categories of exports approved in advance by the Executive Branch as constituting permitted incidental assistance.

\subsection{Export licensing criteria.}


(a) The review of license applications for export for peaceful nuclear uses of production or utilization facilities 1 or for export for peaceful nuclear uses of special nuclear or source material requiring a specific license under this part is governed by the following criteria:

(7) The proposed export of a facility or of more than 0.003 effective kilograms of special nuclear material, other than plutonium containing 80 percent or more by weight of plutonium-238, would be under the terms of an agreement for cooperation.

(8) The proposed export is not inimical to the common defense and security and, in the case of facility exports, does not constitute an unreasonable risk to the public health and safety in the United States.

(9)(i) Except as provided in paragraph (a)(9)(ii) of this section, with respect to exports of highenriched uranium to be used as a fuel or target in a nuclear research or test reactor, the Commission determines that:

(A) There is no alternative nuclear reactor fuel or target enriched to less than 20 percent in the isotope $\mathrm{U}-235$ that can be used in that reactor;

(B) The proposed recipient of the uranium has provided assurances that, whenever an alternative nuclear reactor fuel or target can be used in that reactor, it will use that alternative fuel or target in lieu of highly enriched uranium; and

(C) The United States Government is actively developing an alternative nuclear reactor fuel or target that can be used in that reactor.

(ii) With regard to a Recipient Country, the Commission may issue a license authorizing the export of high-enriched uranium for medical isotope production, including shipment to and use at intermediate and ultimate consignees, if the Commission determines that:

(A) The Recipient Country that supplies an assurance letter to the United States Government in connection with the consideration by the Commission of the export license application has informed the United States Government that any intermediate consignees and the ultimate consignee specified in the export license application are required to use the high-enriched uranium solely for the production of medical isotopes; and

(B) The high-enriched uranium will be irradiated only in a reactor in the Recipient Country that-

(1) Uses an alternative nuclear fuel; or

(2) Is the subject of an agreement with the United States Government to convert to an alternative nuclear reactor fuel when alternative nuclear reactor fuel can be used in the reactor.

(iii) A fuel or target "can be used" in a nuclear research or test reactor if--

(A) The fuel or target has been qualified by the Reduced Enrichment Research and Test Reactor Program of the Department of Energy; and

(B) Use of the fuel or target will permit the large majority of ongoing and planned experiments and isotope production to be conducted in the reactor without a large percentage increase in the total cost of operating the reactor.

(c) Except where paragraph (d) is applicable, the review of license applications for export of byproduct material or for export of source material for non-nuclear end uses requiring a specific license under this 
part is governed by the criterion that the proposed export is not inimical to the common defense and security.

(d) The review of license applications for the export of radioactive waste requiring a specific license under this part is governed by the following criteria:

(1) The proposed export is not inimical to the common defense and security.

(2) The receiving country, after being advised of the information required by $\S 110.32(f)(5)$, finds that it has the administrative and technical capacity and regulatory structure to manage and dispose of the waste and consents to the receipt of the radioactive waste. In the case of radioactive waste containing a nuclear material to which paragraph (a) or (b) of this section is applicable, the criteria in this paragraph (d) shall be in addition to the criteria provided in paragraph (a) or (b) of this section.

(e) In making its findings under paragraphs (a)(8) and (c) of this section for proposed exports of radioactive material listed in Appendix P to this part, the NRC shall consider:

(1) Whether the foreign recipient is authorized based on the authorization or confirmation required by $\S 110.32(\mathrm{~h})$ to receive and possess the material under the laws and regulations of the importing country;

(2) Whether the importing country has the appropriate technical and administrative capability, resources and regulatory structure to manage the material in a safe and secure manner;

(3) For proposed exports of Category 1 amounts of radioactive material listed in Table 1 of Appendix $\mathrm{P}$ to this part, whether the government of the importing country provides consent to the United States Government for the import of the material;

(4) In cases where the importing country does not have the technical and administrative capability described in paragraph (e)(2) of this section, and in cases where there is insufficient evidence of the recipient's authorization to receive and possess the material to be exported, described in paragraph (e)(1) of this section, whether exceptional circumstances exist, and if so, whether the export should be licensed in light of those exceptional circumstances and the risks, if any, to the common defense and security of the proposed export;

(5) For proposed exports under exceptional circumstances of Category 1 or Category 2 amounts of radioactive material listed in Table 1 of Appendix $P$ to this part, whether the government of the importing country provides consent to the United States Government for the import of the material;

(6) For proposed exports of radioactive material listed in Table 1 of Appendix $P$ to this part under the exceptional circumstance in which there is a considerable health or medical need as acknowledged by the U.S. Government and the importing country, whether the United States and the importing country have, to the extent practicable, made arrangements for the safe and secure management of the radioactive sources during and at the end of their useful life;

(7) Based upon the available information, whether the foreign recipient has engaged in clandestine or illegal procurement of radioactive material listed in Table 1 of Appendix $\mathrm{P}$ to the part;

(8) Based upon available information, whether an import or export authorization for radioactive material listed in Table 1 of Appendix P to this part has been denied to the recipient or importing country, or whether the recipient or importing country has diverted any import or export of radioactive material previously authorized; and 
(9) Based upon available information, whether there is a risk of diversion or malicious acts involving radioactive material in Table 1 of Appendix $P$ to this part.

\section{Appendix M to Part 110 - Categorization of Nuclear Material}

This appendix refers to IAEA INFCIRC/225, Rev 1, which had the 10\% U235, 20\% U235, and 80\% Pu238 criteria.

\section{Appendix P to Part 110 - Category 1 and 2 Radioactive Material}

Table 11 of report. Table 1 (of 10CFR110 Appendix P) - Import and Export Threshold Limits.

\begin{tabular}{|l|c|r|r|r|}
\hline & \multicolumn{2}{|c|}{ Category 1 } & \multicolumn{2}{c|}{ Category 2 } \\
\hline & $\begin{array}{c}\text { Terabequerels } \\
(\mathrm{TBq})\end{array}$ & $\begin{array}{c}\text { Curies } \\
(\mathrm{Ci})[1]\end{array}$ & $\begin{array}{c}\text { Terabequerels } \\
(\mathrm{TBq})\end{array}$ & $\begin{array}{c}\text { Curies } \\
(\mathrm{Ci})[1]\end{array}$ \\
\hline Americium-241 & 60 & 1,600 & 0.6 & 16.0 \\
\hline Americium-241/Be & 60 & 1,600 & 0.6 & 16.0 \\
\hline Californium-252 & 20 & 540 & 0.2 & 5.4 \\
\hline Curium-244 & 50 & 1,400 & 0.5 & 14.0 \\
\hline Cobalt-60 & 30 & 810 & 0.3 & 8.1 \\
\hline Cesium-137 & 100 & 2,700 & 1.0 & 27.0 \\
\hline Gadolinium-153 & 1,000 & 27,000 & 10.0 & 270.0 \\
\hline Iridium-192 & 80 & 2,200 & 0.8 & 22.0 \\
\hline Plutonium-238 [2] & 60 & 1,600 & 0.6 & 16.0 \\
\hline Plutonium-239/Be [2] & 60 & 1,600 & 0.6 & 16.0 \\
\hline Promethium-147 & 40,000 & $1,100,000$ & 400.0 & $11,000.0$ \\
\hline Radium-226 [a] & 40 & 1,100 & 0.4 & 11.0 \\
\hline Selenium-75 & 200 & 5,400 & 2.0 & 54.0 \\
\hline Strontium-90 (Y-90) & 1,000 & 27,000 & 10.0 & 270.0 \\
\hline Thulium-170 & 20,000 & 540,000 & 200.0 & $5,400.0$ \\
\hline Ytterbium-169 & 300 & 8,100 & 3.0 & 81.0 \\
\hline
\end{tabular}

1 The values to be used to determine whether a license is required are given in TBq. Curie (Ci) values are provided for practical usefulness only and are rounded after conversion.

2 The limits for $\mathrm{Pu}-238$ and $\mathrm{Pu}-239 / \mathrm{Be}$ in this table apply for imports to the U.S. The limits for exports of $\mathrm{Pu}-238$ and $\mathrm{Pu}-239 / \mathrm{Be}$ can be found in $\S 110.21$.

a Discrete sources of radium-226.

\section{Calculation of Shipments Containing Multiple Sources or Radionuclides}

The "sum of fractions" methodology for evaluating combinations of radionuclides being transported, is to be used when import or export shipments contain multiple sources or multiple radionuclides. The threshold limit values used in a sum of the fractions calculation must be the metric values (i.e., TBq).

I. If multiple sources and/or multiple radionuclides are present in an import or export shipment, the sum of the fractions of the activity of each radionuclides must be determined to verify the shipment is less than the Category 1 or 2 limits of Table 1, as appropriate. If the calculated sum of the fractions ratio, using the following equation, is greater than or equal to 1.0 , then the import or export shipment exceeds the threshold limits of Table 1 and the applicable security provisions of this part apply. 
II. Use the equation below to calculate the sum of the fractions ratio by inserting the actual activity of the applicable radionuclides or of the individual sources (of the same radionuclides) in the numerator of the equation and the corresponding threshold activity limit from the Table 1 in the denominator of the equation. Ensure the numerator and denominator values are in the same units and all calculations must be performed using the TBq (i.e., metric) values of Table 1.

$\mathrm{Rl}$ - activity for radionuclides or source number $\mathrm{l}$

$\mathrm{R} 2$ - activity for radionuclides or source number 2

$\mathrm{RN}$ - activity for radionuclides or source number $\mathrm{n}$

$\mathrm{ARl}$ - activity limit for radionuclides or source number 1

AR2 - activity limit for radionuclides or source number 2

ARN - activity limit for radionuclides or source number $n$

$$
\sum_{1}^{n}\left[\frac{\mathrm{R}_{1}}{\mathrm{AR}_{1}}+\frac{\mathrm{R}_{2}}{\mathrm{AR}_{2}}+\frac{\mathrm{R}_{\mathrm{n}}}{\mathrm{AR}_{\mathrm{n}}}\right] \geq 1
$$

\subsubsection{Part 140 - Financial Protection Requirements and Indemnity Agreements.}

\subsection{Scope.}

(a) The regulations in this part apply:

(1) To each person who is an applicant for or holder of a license issued under 10 CFR parts 50,52 , or 54 to operate a nuclear reactor, and

(2) With respect to an extraordinary nuclear occurrence, to each person who is an applicant for or holder of a license to operate a production facility or a utilization facility (including an operating license issued under part 50 of this chapter and a combined license under part 52 of this chapter), and to other persons indemnified with respect to the involved facilities.

(3) To each person licensed pursuant to part 70 of this chapter to possess and use plutonium in a plutonium processing and fuel fabrication plant.

(4) To each person licensed pursuant to parts 40 and 70 of this chapter to construct and operate a uranium enrichment facility.

(b)(1) Subpart B of this part does not apply to any person subject to subparts C or D of this part. Subpart $C$ of this part applies only to persons found by the Commission to be Federal agencies. Subpart $D$ of this part applies only to persons found by the Commission to be nonprofit educational institutions with respect to licenses and applications for licenses for the conduct of educational activities.

(2) Any applicant or licensee subject to this part may apply for a finding that such applicant or licensee is subject to the provisions of subparts $C$ or $D$ of this part. The application should state the grounds for the requested finding. Any application for a finding pursuant to this paragraph may be included in an application for license. 


\subsection{IAEA Documents}

International documents do not have legal force in the U.S. However, often US and international documents and terminology have been harmonized, such as the physical protection inventory thresholds in IAEA INFCIRC/25 and 10CFR74.

\subsubsection{IAEA, "Treaty on the Non-Proliferation of Nuclear Weapons," INFCIRC/140, April 22, 1970.}

Important treaty, but it provides no definitions or terminology relevant to the present task.

\subsubsection{IAEA, "The Structure and Content of Agreements Between the Agency and States Required in Connection with the Treaty on the Non- Proliferation of Nuclear Weapons," INFCIRC/153, June 1972.}

Historically, this is very important as it establishes the basic safeguard structure. To date, it is the first reference the author has found to the $80 \%$ Pu238 and $20 \%$ U235 criteria. And, it is the earliest place found of $5 \%$ enrichment of uranium and plutonium as a criterion threshold, namely in section 80 where that factors into frequency of inspections.

Italics below are in the original.

\section{Exemptions from Safeguards}

36. The Agreement should provide that the Agency shall, at the request of the State, exempt nuclear material from safeguards, as follows:

(a) Special fissionable material, when it is used in gram quantities or less as a sensing component in instruments;

(b) Nuclear material, when it is used in non-nuclear activities in accordance with paragraph 13 above, if such nuclear material is recoverable; and

(c) Plutonium with an isotopic concentration of plutonium-238 exceeding $80 \%$.

37. The Agreement should provide that nuclear material that would otherwise be subject to safeguards shall be exempted from safeguards at the request of the State, provided that nuclear material so exempted in the State may not at any time exceed:

(a) One kilogram in total of special fissionable material, which may consist of one of more of the following:

(i) Plutonium;

(ii) Uranium with an enrichment of $0.2(20 \%)$ and above, taken account of by multiplying its weight by its enrichment; and

(iii) Uranium with an enrichment below $0.2(20 \%)$ and above that of natural uranium, taken account of by multiplying its weight by five times the square of its enrichment;

(b) Ten metric tons in total of natural uranium and depleted uranium with an enrichment above 0.005 $(0.5 \%)$

(c) Twenty metric tons of depleted uranium with an enrichment of $0.005(0.5 \%)$ or below; and 
(d) Twenty metric tons of thorium;

or such greater amounts as may be specified by the Board of Governors for uniform application.

38. The Agreement should provide that if exempted nuclear material is to be processed or stored together with safeguarded nuclear material, provision should be made for the re-application of safeguards thereto.

\section{Frequency and intensity of routine inspections}

80. The Agreement should provide that the maximum routine inspection effort in respect of facilities with a content or annual throughput of nuclear material exceeding five effective kilograms shall be determined as follows:

(a) For reactors and sealed stores, the maximum total of routine inspection per year shall be determined by allowing one sixth of a man year of inspection for each such facility in the State;

(b) For other facilities involving plutonium or uranium enriched to more than $5 \%$, the maximum total of routine inspection per year shall be determined by allowing for each such facility $30 \mathrm{X} \vee \mathrm{E}$ mandays of inspection per year, where $\mathrm{E}$ is the inventory or annual throughput of nuclear material, whichever is greater, expressed in effective kilograms. The maximum established for any such facility shall not, however, be less than 1.5 man-years of inspection; and

(c) For all other facilities, the maximum total of routine inspection per year shall be determined by allowing for each such facility one third of a man-year of inspection plus $0.4 \mathrm{X} \mathrm{E}$ man-days of inspection per year, where $\mathrm{E}$ is the inventory or annual throughput of nuclear material, whichever is greater, expressed in effective kilograms.

The Agreement should further provide that the Agency and the State may agree to amend the maximum figures specified in this paragraph upon determination by the Board that such amendment is reasonable. 


\subsubsection{IAEA, "The Physical Protection of Nuclear Material," INFCIRC/225, September 1975.}

Table 12 of report. Table I (of INFCIRC/225). Categorization of Nuclear Material.

\begin{tabular}{|c|c|c|c|c|}
\hline Material & Form & Category I & Category II & Category III \\
\hline Plutonium & $\begin{array}{l}\text { Unirradiated } \\
-\quad \text { Not easily dispersible } \\
\text { - } \quad \text { Easily dispersible }\end{array}$ & $\begin{array}{l}2 \mathrm{~kg} \text { or more } \\
2 \mathrm{~kg} \text { or more }\end{array}$ & $\begin{array}{l}\text { Less than } 2 \mathrm{~kg} \text { but } \\
\text { more than } 500 \mathrm{~g} \\
\text { Less than } 2 \mathrm{~kg} \text { but } \\
\text { more than } 10 \mathrm{~g}\end{array}$ & $\begin{array}{l}500 \mathrm{~g} \text { or less [c] } \\
10 \mathrm{~g} \text { or less }[\mathrm{c}]\end{array}$ \\
\hline $\begin{array}{l}\text { Uranium- } \\
235\end{array}$ & $\begin{array}{l}\text { Unirradiated, any chemical } \\
\text { form } \\
\text { - Uranium enriched to } \\
20 \% \text { U } 235 \text { or more } \\
\text { - Uranium enriched to } \\
10 \% \mathrm{U} \text { but less than } \\
20 \% \\
\text { - Uranium enriched } \\
\text { above natural, but less } \\
\text { than } 10 \% \text { U235 }\end{array}$ & $5 \mathrm{~kg}$ or more & $\begin{array}{l}\text { Less than } 5 \mathrm{~kg} \text { but } \\
\text { more than } 1 \mathrm{~kg} \\
10 \mathrm{~kg} \text { or more }\end{array}$ & $\begin{array}{l}1 \mathrm{~kg} \text { or less [c] } \\
\text { Less than } 10 \mathrm{~kg}[\mathrm{c}] \\
10 \mathrm{~kg} \text { or more }\end{array}$ \\
\hline $\begin{array}{l}\text { Uranium- } \\
233\end{array}$ & $\begin{array}{l}\text { Unirradiated, any chemical } \\
\text { form }\end{array}$ & $2 \mathrm{~kg}$ or more & $\begin{array}{l}\text { Less than } 2 \mathrm{~kg} \text { but } \\
\text { more than } 500 \mathrm{~g}\end{array}$ & $500 \mathrm{~g}$ or less $[\mathrm{c}]$ \\
\hline $\begin{array}{l}\text { Irradiated } \\
\text { fuel }\end{array}$ & & $\begin{array}{l}\text { Reprocessing plant } \\
\text { Storage facilities } \\
\text { separated from } \\
\text { reactor sites }\end{array}$ & Reactor site $[\mathrm{b}]$ & \\
\hline \multicolumn{5}{|c|}{$\begin{array}{l}\text { a. Natural uranium, depleted uranium and thorium and quantities of uranium enriched to less than } 10 \% \\
\text { not falling in Category III should be protect in accordance with prudent management practice. } \\
\text { b. Although the recommendations of the group of experts are for this level of protection, it would be } \\
\text { open to States, upon evaluation of reactor characteristics, to assign a different degree of physical } \\
\text { protection. } \\
\text { c. Less than a radiologically significant quantity should be exempted. }\end{array}$} \\
\hline
\end{tabular}

\subsubsection{IAEA, "The Physical Protection of Nuclear Material," INFCIRC/225/Rev.4 (Corrected), June 1999.}

The original INFCIRC table in 1975 had the $10 \%$ U235 and $20 \%$ U235 criteria. The $80 \%$ Pu 238 and $100 \mathrm{rad} / \mathrm{hr}$ criteria in the table below were added at Rev 1 in 1978 and retained thereafter. 
Table 13 of report. Table (of INFCIRC/225/Rev4): Categorization of Nuclear Material.

\begin{tabular}{|c|c|c|c|c|}
\hline Material & Form & Category I & Category II & Category III [c] \\
\hline Plutonium [a] & Unirradiated $[\mathrm{b}]$ & $\mathrm{X} \geq 2 \mathrm{~kg}$ & $2 \mathrm{~kg}>X>500 \mathrm{~g}$ & $500 \mathrm{~g} \geq X>15 \mathrm{~g}$ \\
\hline Uranium-235 & $\begin{array}{l}\text { Unirradiated [b] } \\
\text {-Uranium enriched to } \\
20 \% \text { U235 or more } \\
\text {-Uranium enriched to } \\
10 \% \text { U but less than } \\
20 \% \text { U235 } \\
\text {-Uranium enriched } \\
\text { above natural, but } \\
\text { less than } 10 \% \text { U235 }\end{array}$ & $X \geq 5 \mathrm{~kg}$ & $X \geq 10 \mathrm{~kg}$ & $\begin{array}{r}1 \mathrm{~kg} \geq X>15 \mathrm{~g} \\
10 \mathrm{~kg}>X>1 \mathrm{~kg} \\
\quad X \geq 10 \mathrm{~kg}\end{array}$ \\
\hline Uranium-233 & Unirradiated $[\mathrm{b}]$ & $\mathrm{X} \geq 2 \mathrm{~kg}$ & $2 \mathrm{~kg}>X>500 \mathrm{~g}$ & $500 \mathrm{~g} \geq X>15 \mathrm{~g}$ \\
\hline $\begin{array}{l}\text { Irradiated fuel } \\
\text { (The } \\
\text { categorization of } \\
\text { irradiated fuel in } \\
\text { the table is based } \\
\text { on international } \\
\text { transport } \\
\text { considerations. } \\
\text { The State may } \\
\text { assign a } \\
\text { different } \\
\text { category for } \\
\text { domestic use, } \\
\text { storage, and } \\
\text { transport taking } \\
\text { all relevant } \\
\text { factors into } \\
\text { account.) }\end{array}$ & & & $\begin{array}{l}\text { Depleted or } \\
\text { natural uranium, } \\
\text { thorium or low- } \\
\text { enriched fuel (less } \\
\text { than } 10 \% \text { fissile } \\
\text { content) }[\mathrm{d} / \mathrm{e}]\end{array}$ & \\
\hline \multicolumn{5}{|c|}{$\begin{array}{l}\text { a. All plutonium except that with isotopic concentration exceeding } 80 \% \text { in plutonium- } 238 \text {. } \\
\text { b. Material not irradiated in a reactor or material irradiated in a reactor but with a radiation level equal to } \\
\text { or less than } 1 \mathrm{~Gy} / \mathrm{hr}(100 \mathrm{rad} / \mathrm{hr}) \text { at one meter unshielded. } \\
\text { c. Quantities not falling in Category III and natural uranium, depleted uranium and thorium should be } \\
\text { protected at least in accordance with prudent management practice. } \\
\text { d. Although the recommendations of the group of experts are for this level of protection, it would be } \\
\text { open to States, upon evaluation of reactor characteristics, to assign a different degree of physical } \\
\text { protection. } \\
\text { e. Other fuel which by virtue of its original fissile material content is classified as Category I or II before } \\
\text { irradiation may be reduced one category level while the radiation level from the fuel exceeds } 1 \mathrm{~Gy} / \mathrm{hr} \\
(100 \mathrm{rad} / \mathrm{hr}) \text { at one meter unshielded. }\end{array}$} \\
\hline
\end{tabular}

